Plant
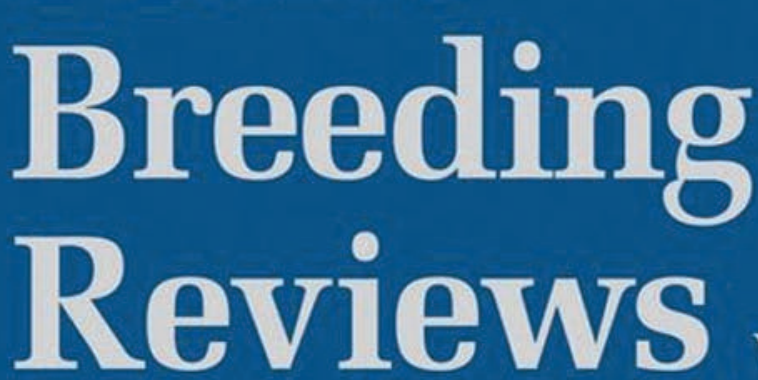

VOLUME 26 


\section{Using Genomics to Exploit Grain Legume Biodiversity in Crop Improvement*}

Sangam L. Dwivedi, Hari D. Upadhyaya, Jayashree Balaji, and Hutokshi K. Buhariwalla

International Crops Research Institute for the Semi-Arid Tropics (ICRISAT)

Patancheru, PO 502324, A.P.

India

Matthew W. Blair

Centro internacional de Agricultura Tropical (CIAT)

A.A. 6713 Cali

Colombia

Rodomiro Ortiz and Jonathan H. Crouch

CIMMYT Apdo. Postal 6-641, 0660 Mexico, D.F., Mexico

Richard Serraj

Soil and Water Management \& Crop Nutrition Section, Joint

FAO/IAEA Division, Wagramer Strasse 5, A-1400 Vienna, Austria

I. INTRODUCTION

A. Phylogeny and Taxonomy

B. Production and Uses

C. Major Constraints

1. Diseases and pests

2. Environmental stress

D. Variation in Legume Genomes

${ }^{*}$ Generation Challenge Program, Cultivating Plant Diversity for the Resource Poor (www.generationcp.org).

Plant Breeding Reviews, Volume 26, Edited by Jules Janick ISBN 0-471-73215-X @ 2006 John Wiley \& Sons, Inc. 
II. AVAILABLE GENETIC RESOURCES OF KEY LEGUME CROPS
A. Tropical Legumes
B. Temperate Legumes
C. Model Species Related to Grain Legumes

III. MANAGEMENT AND UTILIZATION OF LEGUME GENETIC RESOURCES
A. Collection and Enhancement
B. Regeneration and Conservation
C. Characterization, Evaluation, and Documentation
D. Core Collection
E. Elite Germplasm, Genetic Stock, and Cultivar
F. Wild Species Germplasm

IV. IMPACT OF GENETIC RESOURCES IN CONVENTIONAL LEGUME BREEDING
A. Germplasm Distribution
B. Impact of Domesticated Germplasm on Breeding Gains
C. Use of Wild Germplasm
D. Conclusions from Conventional Manipulation of Genetic Resources

V. MOLECULAR-ENHANCED STRATEGIES FOR MANIPULATING NOVEL GENETIC VARIATION FOR LEGUME BREEDING
A. Interspecific Hybridization
B. Linkage Mapping and QTL Detection
C. Linkage Disequilibrium and Association Mapping
D. Dissection and Manipulation of Legume Physiology

VI. ADVANCED APPLICATIONS IN LEGUME MOLECULAR BREEDING

A. Comparative Genomics and Allele Mining

B. Functional Genomics and Gene Discovery

C. New Technologies for Marker-Assisted Selection

1. High-throughput SSR marker genotyping

2. Simple markers from fingerprinting assays

3. Gel-free diagnostics

4. Trait-specific SNP markers

5. Array-based genotyping

D. Successful Applications of Molecular Breeding in Legumes

VII. CONCLUSIONS AND FUTURE PROSPECTS

LITERATURE CITED

\section{LIST OF ABBREVIATIONS}

$\begin{array}{ll}\text { ACCase } & \text { Acetyl-CoA carboxylase } \\ \text { AFLP } & \text { Amplified Fragment Length Polymorphism } \\ \text { AM } & \text { Arbuscular mycorrhiza } \\ \text { ASAPs } & \text { Allele specific associated primers } \\ \text { ASH } & \text { Allele specific hybridization } \\ \text { AVRDC } & \text { Asian Vegetable Research and Development Centre } \\ \text { BAC } & \text { Bacterial Artificial Chromosome } \\ \text { BAMNET } & \text { The International Bambara Groundnut Network, } \\ & \text { Germany }\end{array}$




$\begin{array}{ll}\text { BCMNV } & \text { Bean common mosaic necrosis virus } \\ \text { BCMV } & \text { Bean common mosaic virus } \\ \text { BLAST } & \text { Basic Local Alignment Search Tool } \\ \text { CAPS } & \text { Cleaved Amplified Polymorphic Sequences } \\ \text { CBB } & \text { Common bacterial blight } \\ \text { CE } & \text { Capillary electrophoresis } \\ \text { CGIAR } & \text { Consultative Group on International Agriculture } \\ \text { CIAT } & \text { Centro Internacional de Agricultura Tropical } \\ \text { CIMMYT } & \text { International Maize and Wheat Improvement Centre } \\ \text { CMS } & \text { Cytoplasmic male sterility } \\ \text { COS } & \text { Conserved ortholog sequence } \\ \text { CRSP } & \text { Collaborative Research Support Project } \\ \text { CSIRO } & \text { Commonwealth of Scientific and Industrial } \\ & \text { Organization } \\ \text { cDNA } & \text { Complementary Deoxyribonucleic acid } \\ \text { DAGAT } & \text { Diacylglycerol acyltransferase } \\ \text { DArT } & \text { Diversity Arrays Technology } \\ \text { DH } & \text { Double haploids } \\ \text { DNA } & \text { Deoxyribonucleic acid } \\ \text { ELISA } & \text { Enzyme-Linked Immunosorbent Assay } \\ \text { EST } & \text { Expressed sequenced tags } \\ \text { FAO } & \text { Food and Agricultural Organization } \\ \text { FASTA } & \text { FAST Algorithm for sequence alignment } \\ \text { IARCs } & \text { International Agriculture Research Centers } \\ \text { IBPGR } & \text { International Bureau Plant Genetic Resources } \\ \text { ICARDA } & \text { International Center for Agricultural Research in the } \\ & \text { Dry Areas } \\ \text { ICRISAT } & \text { International Crops Research Institute for the Semi Arid } \\ & \text { Tropics } \\ \text { IITA } & \text { International Institute of Tropical Agriculture } \\ \text { ILRC } & \text { Inverted repeat-loss clade } \\ \text { ILRI } & \text { International Livestock Research Institute } \\ \text { INIA } & \text { O Instituto Nacional de Investigação Agrária, Portugal } \\ \text { IPGRI } & \text { International Plant Genetic Resources Institute } \\ \text { IPK } & \text { Institut fur Pflanzengenetik und } \\ & \text { Kulturpflanzenforschung } \\ \text { IRRI } & \text { International Rice Research Institute } \\ \text { IVR } & \text { Vavilov Institute of Plant Industry } \\ \text { LIMS } & \text { Laboratory Information Management Systems } \\ \text { LD } & \text { Linkage disequilibrium } \\ \text { LG } & \text { Linkage Groups } \\ \text { LRR } & \text { Leucine-rich repeat } \\ & \end{array}$




$\begin{array}{ll}\text { MADRP } & \text { Ministério da Agricultura Desenvolvimento Rural e } \\ & \text { Pescas, Portugal } \\ \text { MAS } & \text { Marker-assisted selection } \\ \text { NARSs } & \text { National Agricultural Research Systems } \\ \text { NBPGR } & \text { National Bureau of Plant Genetic Resources } \\ \text { NBS } & \text { Nucleotide-binding sites } \\ \text { NILs } & \text { Near isogenic lines } \\ \text { NSF } & \text { National Science Foundation } \\ \text { ODAP } & \beta \text {-N-oxalyl-L- } \alpha \text {, } \beta \text {-diaminopropionic acid } \\ \text { QTL } & \text { Quantitative trait loci } \\ \text { RAPD } & \text { Random Amplified Polymorphic DNA } \\ \text { RFLP } & \text { Restriction fragment length polymorphism } \\ \text { RILs } & \text { Recombinant inbred lines } \\ \text { RNA } & \text { Ribonucleic acid } \\ \text { SAGE } & \text { Serial analysis of gene expression } \\ \text { SCAR } & \text { Sequenced characterized amplified region } \\ \text { SCN } & \text { Soybean cyst nematode } \\ \text { SNF } & \text { Symbiotic nitrogen fixation } \\ \text { SNP } & \text { Single Nucleotide Polymorphism } \\ \text { SSR } & \text { Simple Sequence Repeats } \\ \text { TAGs } & \text { Triacylglycerols } \\ \text { TAM } & \text { Tagged Microarray marker } \\ \text { TCS } & \text { Tentative consensus sequences } \\ \text { TIGR } & \text { The Institute for Genomic Research } \\ \text { TILLING } & \text { Targetting induced local lesions in genomes } \\ \text { TIR } & \text { Toll/Interleukin-1 cytoplasmic receptor } \\ \text { USDA-ARS } & \text { United States Department of Agriculture-Agricultural } \\ & \text { Research Service }\end{array}$

\section{INTRODUCTION}

\section{A. Phylogeny and Taxonomy}

Legumes represent the second largest family of higher plants, second only to grasses in agricultural importance (Doyle and Luckow 2003). The legume family or Leguminosae, also known as Fabaceae, consists of about 20,000 species across 700 genera that have traditionally been divided into three subfamilies (Caesalpinoideae, Mimosoideae, and Papilionoideae) based largely on floral characteristics. The Papilionoideae subfamily is the largest of the three subfamilies with 476 genera and about 14,000 species, whereas the Mimosoideae subfamily 
contains 77 genera and 3000 species and the Caesalpinoideae subfamily contains 162 genera and 3000 species (Lewis et al. 2003). There are two major groups of cultivated species in the Papilionoideae: the tropical or 'phaseoloid' legumes (including Phaseolus, Vigna, Glycine, and Cajanus) and the temperate or 'galegoid' legumes (including Melilotus, Trifolium, Medicago, Pisum, Vicia, Lotus, Cicer, Lens, and Lathyrus). Phylogenetically, the temperate legumes can be differentiated by the absence of one copy of an approximately $25 \mathrm{~kb}$ inverted repeat, commonly found in the chloroplast genomes of most angiosperms, and therefore are known collectively as members of the inverted repeat-loss clade (IRLC). Lupins and peanuts are somewhat distinct from the phaseoloid and galegoid groups of grain legumes. The phenotypic similarities between many of the grain legumes have led to a plethora of English common names with pea or bean suffixes for the various crop species.

All legumes, from giant Caesalpinoid rainforest trees to tiny Papilionoid annual herbs, are united by descent from a single common form (Doyle et al. 2000; Kajita et al. 2001; Doyle and Luckow 2003). Molecular phylogenetic relationship studies within the Leguminoseae (Wojciechowski 2003) have revealed that the Papilionoideae diverged from other legumes as early as 45 to 50 million years ago, and that the Papilionoideae and Mimosoideae are both monophyletic (i.e., the clades include an ancestor plus all its descendents and no extraneous, unrelated taxa), while the Caesalpiniodeae are paraphyletic (i.e., the clade comprises a diverse assemblage of unrelated lineages lacking the distinctive floral features used to group genera into the other two subfamilies).

Given the taxonomic distinctness and importance of the legume family, two model species have already emerged: Medicago truncatula (www.noble.org/medicago) and Lotus japonicus (http://cryo.naro.affrc.go .jp/sakumotu/mameka/lotus-e.htm). A number of laboratories across the world adopted one or other of these two species as a model system for the study of symbiotic nitrogen fixation but they are now model species for the whole legume biology and genomic community. Scientists now study these species to investigate a range of questions from disease resistance to environmental tolerance and from bacterial and fungal symbiosis to complex secondary metabolism. Indeed, it is expected that the large-scale sequencing of these legume genomes will greatly synergize legume crop biology and molecular breeding just as the full sequencing of the Arabidopsis genome has revolutionized fundamental plant research. As both Medicago and Lotus are temperate forage species, there is still a need to study other species for characters uniquely associated with grain development and to better represent the tropical phaseoloid clade. Soybean is receiving by far the largest research investment 
amongst the legumes due to its pre-eminent global economic value. However, the large degree and complexity of genome duplication in soybean confounds any attempts at developing it as a model genome. Genome sizes vary considerably between members of the Phaseoloid clade (tropical legume species): common bean, mung bean, and cowpea (574 to $637 \mathrm{Mbp}$ ), pigeonpea (784 to $882 \mathrm{Mbp}$ ), and soybean (1115 Mbp). Thus, common bean is probably the strongest candidate as a hub species for the phaseoloid clade in view of a relatively small genome and good progress in the development of genomics and germplasm resources.

In a recent survey of grain legume genomics research in advanced labs (Vandenbosch and Stacey 2003), ten groups were highlighted for $M$. truncatula, five for L. japonicus, four for soybean, and two for Phaseolus. These had an emphasis on marker development, genetic linkage maps, genome sequences, ESTs, expression arrays, genetic transformation, gene cloning, functional genomics, plant-microbe interactions, molecular genetics and breeding, and conservation of genetic resources of these legumes. International genomics consortia have also been established for Medicago, Lotus, Phaseolus, soybean, chickpea, and pea. It is expected that the genetic and genomic resources developed through these consortia will be freely available to those engaged in enhancing the genetic potential of these legumes.

\section{B. Production and Uses}

The importance of legumes is paramount for world agriculture. Although legumes account for just $15 \%$ of arable farming land worldwide, they play a vital role in agroecosystem health. Legumes improve soil health through biological nitrogen fixation and enhance human nutritional well-being through their role as a major source of protein among poor consumers and subsistence farming communities of the developing world (Crouch et al. 2004; Ortiz 2004a) (Table 6.1). Legumes fix substantial quantities of biological nitrogen by virtue of their symbiotic association with Rhizobium bacteria (Schultze and Kondorosi 1998; Serraj 2004), ranging from potential rates of 20 to $260 \mathrm{~kg} \mathrm{ha}^{-1} \mathrm{~N} 2$ for soybean [Glycine max (L.) Merr.], 73 to $80 \mathrm{~kg} \mathrm{ha}^{-1}$ for cowpea [Vigna unguiculata (L.) Walp.], 72 to $240 \mathrm{~kg} \mathrm{ha}^{-1}$ for peanut (Arachis hypogaea L.), 40 to $350 \mathrm{~kg} \mathrm{ha}^{-1}$ for alfalfa (Medicago sativa L.) and clover (Trifolium ssp.) (Yamada 1974); to $69 \mathrm{~kg} \mathrm{ha}^{-1}$ for pigeonpea (Cajanus cajan L.) (Kumar et al. 1983). The capacity for biological nitrogen fixation is particularly important in developing countries where legumes can and do reduce the dependency of resource-poor farmers on expensive petroleum-based, chemical fertilizers, while simultaneously improving soil and water 
Table 6.1. Legume food supply statistics for ASIA, Latin America and sub-Saharan Africa from 1961 to $2000 .^{z}$

\begin{tabular}{|c|c|c|c|c|c|c|c|c|c|}
\hline \multirow[b]{3}{*}{ Commodity } & \multicolumn{4}{|c|}{1961} & \multicolumn{4}{|c|}{2000} & \multirow{3}{*}{$\begin{array}{l}\text { Growth rate } \\
\text { Within diet } \\
(40 \text { year } \%)^{y}\end{array}$} \\
\hline & \multirow{2}{*}{$\begin{array}{c}\text { Supply } \\
\left(\text { kg year }^{-1}\right)\end{array}$} & Calorie & Protein & Fat & \multirow{2}{*}{$\begin{array}{c}\text { Supply } \\
\left(\mathrm{kg} \mathrm{year}^{-1}\right)\end{array}$} & Calorie & Protein & Fat & \\
\hline & & \multicolumn{3}{|c|}{ (per caput daily) } & & \multicolumn{3}{|c|}{ (per caput daily) } & \\
\hline \multicolumn{10}{|l|}{ Asia } \\
\hline Total food & & 1893 & 48.8 & 24.5 & & 2708 & 71.1 & 65.7 & \\
\hline Crops & & 1783 & 41.6 & 17.0 & & 2340 & 49.8 & 37.5 & \\
\hline Animals & & 110 & 7.2 & 7.5 & & 368 & 21.3 & 28.2 & \\
\hline Pulses & 12.0 & 113 & 7.0 & 0.8 & 5.1 & 48 & 2.9 & 0.4 & -57.5 \\
\hline Beans & 2.7 & 25 & 1.6 & 0.1 & 1.3 & 12 & 0.8 & * & -51.9 \\
\hline Peas & 2.1 & 19 & 1.3 & 0.1 & 0.5 & 4 & 0.3 & * & -76.2 \\
\hline Others & 7.2 & 69 & 4.1 & 0.7 & 3.2 & 32 & 1.9 & 0.3 & -55.6 \\
\hline Oil crops & 6.8 & 49 & 2.9 & 2.9 & 10.4 & 81 & 4.8 & 5.1 & 52.9 \\
\hline Soybean & 2.6 & 24 & 2.3 & 0.8 & 2.9 & 37 & 3.5 & 1.3 & 11.5 \\
\hline Peanut & 0.6 & 9 & 0.4 & 0.7 & 1.6 & 23 & 1.0 & 1.9 & 62.5 \\
\hline Vegetable oil & 2.5 & 61 & * & 6.9 & 9.0 & 21.5 & * & 24.0 & 260.0 \\
\hline Soybean & 0.3 & 7 & 0.1 & 0.8 & 1.9 & 45.0 & * & 5.1 & 533.3 \\
\hline Peanut & 0.8 & 19 & - & 2.1 & 0.9 & 23.0 & - & 2.6 & 12.5 \\
\hline \multicolumn{10}{|c|}{ Central America } \\
\hline Total & & 2297 & 62.5 & 50.8 & & 2934 & 81.3 & 78.2 & \\
\hline Crops & & 2013 & 45.9 & 29.9 & & 2425 & 48.1 & 42.4 & \\
\hline Animal & & 284 & 16.6 & 20.9 & & 509 & 33.2 & 35.7 & \\
\hline
\end{tabular}


Table 6.1. Legume food supply statistics for Asia, Latin America and sub-Saharan Africa from 1961 to 2000. ${ }^{z}$

Growth rate

\begin{tabular}{cc}
\hline $\begin{array}{c}\text { Supply } \\
\left(\mathrm{kg} \mathrm{year}^{-1}\right)\end{array}$ & Calorie Protein $\quad$ Fat \\
${ } }$
\end{tabular}

\begin{tabular}{llll}
\multicolumn{4}{c}{2000} \\
\hline Supply & Calorie & Protein & Fat \\
\cline { 2 - 3 }
\end{tabular}

Commodity

\begin{tabular}{|c|c|c|c|c|c|c|c|c|c|}
\hline Pulses & 16.6 & 159 & 9.0 & 0.8 & 12.7 & 121 & 7.2 & 0.6 & -23.5 \\
\hline Beans & 15.4 & 147 & 8.3 & 0.7 & 11.0 & 105 & 6.0 & 0.5 & -28.6 \\
\hline Peas & 1.0 & 1 & 0.1 & 0.1 & 0.1 & 1 & 0.1 & 0.1 & -90.0 \\
\hline Others & 1.2 & 11 & 0.6 & 0.1 & 1.6 & 15 & 1.1 & 0.1 & 33.3 \\
\hline Oil crops & 2.7 & 21 & 0.7 & 1.7 & 3.2 & 27 & 1.0 & 2.3 & 18.5 \\
\hline Soybean & * & * & * & * & 0.1 & 1 & 0.1 & * & $\approx 00$ \\
\hline Peanut & 0.9 & 14 & 0.6 & 1.1 & 0.9 & 14 & 0.7 & 1.2 & 0.0 \\
\hline Vegetable oil & 5.1 & 123 & * & 13.9 & 9.0 & 218 & * & 24.7 & 76.5 \\
\hline $\begin{array}{l}\text { Soybean } \\
\text { Peanut }\end{array}$ & 0.1 & 1 & 0.1 & 0.2 & 3.9 & 94 & 0.1 & 10.6 & 3800.0 \\
\hline Peanut & 0.1 & * & - & 0.2 & 0.1 & 3 & - & 0.4 & 0.0 \\
\hline \multicolumn{10}{|c|}{ South America } \\
\hline Total food & & 2322 & 62.6 & 49.0 & & 2850 & 76.1 & 82.1 & \\
\hline Crops & & 1909 & 36.4 & 19.9 & & 2263 & 73.4 & 41.3 & \\
\hline Animals & & 413 & 26.2 & 29.2 & & 586 & 38.7 & 40.8 & \\
\hline Pulses & 13.5 & 125 & 8.2 & 0.6 & 10.9 & 101 & 6.6 & 0.5 & -19.3 \\
\hline Beans & 11.9 & 110 & 7.2 & 0.5 & 9.4 & 87 & 5.7 & 0.4 & -21.0 \\
\hline Peas & 0.6 & 6 & 0.4 & * & 0.6 & 6 & 0.4 & * & 0.0 \\
\hline Others & 1.0 & 9 & 0.6 & 0.1 & 0.9 & 8 & 0.6 & 0.1 & -10.0 \\
\hline
\end{tabular}

$\left(\mathrm{kg} \mathrm{year}^{-1}\right)$

(per caput daily)

Within diet 


\begin{tabular}{|c|c|c|c|c|c|c|c|c|c|}
\hline Oil crops & 3.2 & 24 & 0.9 & 2.1 & 8.0 & 38 & 1.6 & 2.8 & 250.0 \\
\hline Soybean & * & * & * & * & 1.2 & 6 & 0.8 & 0.1 & $\approx 00$ \\
\hline Peanut & 0.5 & 13 & - & 1.5 & 0.1 & 2 & - & 0.3 & -80.0 \\
\hline \multicolumn{10}{|c|}{ Sub-Saharan Africa } \\
\hline Total food & & 2059 & 59.6 & 40.5 & & 2226 & 54.2 & 44.4 & \\
\hline Crops & & 1919 & 42.0 & 31.5 & & 2087 & 43.7 & 35.4 & \\
\hline Animals & & 141 & 10.6 & 9.0 & & 140 & 10.5 & 9.0 & \\
\hline Pulses & 10.2 & 94 & 6.2 & 0.5 & 9.5 & 88 & 5.7 & 0.5 & -6.9 \\
\hline Beans & 3.4 & 32 & 2.1 & 0.1 & 2.9 & 27 & 1.7 & 0.1 & -14.7 \\
\hline Peas & 0.9 & 8 & 0.5 & $*$ & 0.5 & 5 & 0.3 & * & -44.4 \\
\hline Others & 5.9 & 55 & 3.6 & 0.3 & 6.1 & 57 & 3.7 & 0.3 & 3.4 \\
\hline Oil crops & 6.7 & 79 & 3.1 & 6.6 & 5.3 & 63 & 2.8 & 4.9 & -20.9 \\
\hline Soybean & 0.2 & 2 & 0.2 & 0.1 & 0.8 & 9 & 0.7 & 0.4 & 300.0 \\
\hline Peanut & 3.5 & 52 & 2.2 & 4.3 & 2.5 & 37 & 1.6 & 3 & -28.6 \\
\hline Vegetable oil & 5.4 & 129 & 0.1 & 14.7 & 7.5 & 181 & 0.1 & 20.5 & 38.9 \\
\hline Soybean & $*$ & 1 & * & 0.1 & 0.6 & 14 & * & 1.6 & $\approx 00$ \\
\hline Peanut & 1 & 25 & - & 2.8 & 1.9 & 45 & - & 5.1 & 90 \\
\hline
\end{tabular}

*Traces

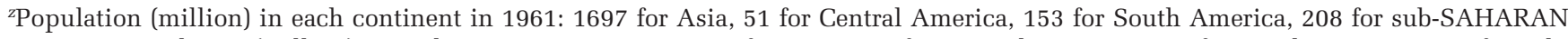
AFRICA. Population (million) in each continent in 2000: 3659 for Asia, 125 for Central America, 345 for South America, 605 for subSAHARAN AFRICA.

yChanges (\%) in the food per caput and legume supply of each commodity for 40-year period (from 1961 to 2000). Ortiz (2004a). 
quality. In addition, many legumes are also able to release soil-bound phosphate through their symbiotic relationships with mycorrhizal fungi (Sanders and Tinker 1973; Hayman 1974, 1983).

In terms of human nutrition, grain legumes are a rich source of protein, lysine, and essential vitamins and minerals (Duranti and Gius 1997; Welch et al. 2000; Grusak 2002). They also contain beneficial secondary compounds with significant health-promoting properties that are reported to provide protection against human cancers and to reduce the risk of high serum cholesterol (Kennedy 1995; Stark and Madar 2002). Legumes can also be milled into flour to make breads, doughnuts, tortillas, chips, spreads, extruded snacks, milk substitutes, yogurts, and infant food (Graham and Vance 2003). Novel uses of specific legumes include popping of some varieties of common bean (Phaseolus vulgaris L.) (Popenoe et al. 1989), production of licorice from Glycyrhiza glabra (Kindscher 1992), and elaboration of soybean candy (Genta et al. 2002). In addition, soybeans are processed into many food products such as tofu and tempeh, and provide $26.6 \%$ of the world's (96.3 M t) processed vegetable oil with a resulting by-product that is a rich source of dietary protein for human food and feed industries (FAO 2002). Meanwhile, forage legumes provide the basis for many meat and dairy industries across the world (Russelle 2001). There are also many industrial uses of both grain and forage legumes including biodegradable plastics, oils, gums, dyes, and inks (Graham and Vance 2003).

Global legume production (225 million t from 132 million ha) is very much dominated by soybean (79.8\%), bean (Phaseolus sps.) (8.1\%), pea (Pisum sativum L.) (4.4\%), and chickpea (Cicer arietinum L.) (3.5\%) (Table 6.2) (FAO 2002). The most commonly grown legume species vary by continent and according to use. For example, chickpea and pigeonpea are important in Asia and bean in Latin America, whereas cowpea and peanut are among the most important food legumes in sub-Saharan Africa. Soybean is an important source of oil in Asia and Latin America, while peanut serves a substantial portion of the vegetable oil demand in sub-Saharan Africa. Thus, the Americas produce $85 \%$ of the world's soybean (180 million t) followed by Asia (13.2\%). Meanwhile, for common bean (Phaseolus vulgaris L.) Asia and the Americas each produced $42 \%$ of the total production (18.3 million t). Conversely, Europe is the largest producer of pea ( $56.4 \%$ of 9.8 million t total produced) followed by Asia (21.8\%) and the Americas (16.0\%). Asia is the largest producer of chickpea ( $87.4 \%$ of 7.8 million t), lentil (Lens culinaris Medik.) (72.5\% of 2.9 million t), pigeonpea (92.3\% of 3.0 million t), and broad bean (Vicia faba L.) (44.4\% of 3.7 million t) (Table 6.3). 
Table 6.2. Global area and production statistics for soybean, beans, peas, chickpea, cowpea, broadbeans, lentil, and pigeonpea in 2002

(http://www.apps.fao.org/page/collections?subset=agriculture).

\begin{tabular}{|c|c|c|}
\hline Crop & $\begin{array}{c}\text { Crop area } \\
\text { (000 ha) }\end{array}$ & $\begin{array}{l}\text { Production } \\
\quad(000 \mathrm{t})\end{array}$ \\
\hline Soybean & $79,410(55.9)^{z}$ & 179,917 (79.8) \\
\hline Beans & 26,837 (18.9) & $18,334 \quad(8.1)$ \\
\hline Peas & $5,812 \quad(4.4)$ & $9,872 \quad(4.4)$ \\
\hline Chickpea & $9,894 \quad(7.0)$ & $7,808 \quad(3.5)$ \\
\hline Cowpea & $9,828 \quad(6.9)$ & $3,728 \quad(1.6)$ \\
\hline Broadbean & $2,446 \quad(1.7)$ & $3,728 \quad(1.6)$ \\
\hline Pigeonpea & $4,157 \quad(2.9)$ & $2,994 \quad(1.3)$ \\
\hline Lentil & $3,623 \quad(2.6)$ & $2,938 \quad(1.3)$ \\
\hline World & 142,007 & 229,319 \\
\hline
\end{tabular}

z\% of world area and production.

Table 6.3. Regional contribution to the global production of soybean, beans, peas, chickpea, broadbean, lentil, cowpea, and pigeonpea in 2002 (http://www.apps.fao.org/page/collections?subset=agriculture).

\begin{tabular}{lrrrrrrrr}
\hline & \multicolumn{8}{c}{ Share of the major grain legumes to the global production (\%) } \\
\cline { 2 - 9 } Region & Soybean & Beans & Peas & $\begin{array}{c}\text { Chick- } \\
\text { pea }\end{array}$ & $\begin{array}{c}\text { Broad- } \\
\text { bean }\end{array}$ & Lentil & Cowpea & $\begin{array}{c}\text { Pigeon- } \\
\text { pea }\end{array}$ \\
\hline Africa & 0.5 & 13.2 & 3.0 & 4.5 & 30.4 & 3.1 & 90.1 & 6.9 \\
Asia & 13.2 & 41.8 & 21.8 & 87.4 & 44.4 & 72.5 & 7.1 & 92.3 \\
Europe & 1.0 & 3.1 & 56.4 & 1.1 & 14.7 & 1.4 & 0.9 & - \\
North Central & & & & & & & & \\
$\quad$ America & 42.7 & 21.6 & 16.0 & 5.2 & 1.1 & 16.0 & 1.2 & 0.1 \\
South America & 42.5 & 20.0 & 0.9 & 0.1 & 2.7 & 0.7 & - & 0.1 \\
Oceania & 0.1 & 0.3 & 1.9 & 1.7 & 6.7 & 6.3 & 0.1 & - \\
\hline
\end{tabular}

National productivity of grain legumes varies greatly between and within regions (Tables 6.4 and 6.5). Average regional legume productivity is substantially higher in the Americas than in Asia and Africa. However, yields of soybean and field bean in China, for example, are at least twice that achieved in India. The prevalence of biotic and abiotic stresses and the level of adoption of technological innovations at the farm level are probably the major sources of yield variation observed across regions and between countries within regions. 
Table 6.4. Top five producers and their average national yield for soybean, beans, peas, chickpea, broadbean, lentil, cowpea, and pigeonpea in 2002

(http://www.apps.fao.org/page/collections?subset=agriculture).

\begin{tabular}{|c|c|c|c|}
\hline Crop & Country & $\begin{array}{l}\text { Production } \\
\qquad(000 \mathrm{t})\end{array}$ & $\begin{array}{l}\text { Average yield } \\
\quad\left(\mathrm{t} \mathrm{ha}^{-1}\right)\end{array}$ \\
\hline \multirow[t]{6}{*}{ Beans } & Brazil & $3,017(16.5)^{\mathrm{z}}$ & 0.73 \\
\hline & India & $3,000(16.4)$ & 0.33 \\
\hline & Mexico & $1,648 \quad(9.0)$ & 0.80 \\
\hline & Myanmar & $1,467 \quad(8.0)$ & 0.79 \\
\hline & China & $1,356 \quad(7.4)$ & 1.12 \\
\hline & USA & $1,360 \quad(7.4)$ & 1.95 \\
\hline \multirow[t]{5}{*}{ Broadbean } & China & $1,550(41.6)$ & 1.55 \\
\hline & Egypt & 440 (11.8) & 3.14 \\
\hline & Ethiopia & 385 (10.3) & 0.96 \\
\hline & France & 309 (8.3) & 3.96 \\
\hline & Australia & $250 \quad(6.7)$ & 1.40 \\
\hline \multirow[t]{5}{*}{ Chickpea } & India & $5,320(68.1)$ & 0.87 \\
\hline & Turkey & $590 \quad(7.6)$ & 0.91 \\
\hline & Pakistan & $362 \quad(4.6)$ & 0.39 \\
\hline & Iran & 250 & 0.33 \\
\hline & Mexico & $240 \quad(3.1)$ & 1.60 \\
\hline \multirow{5}{*}{ Cowpea } & Nigeria & $2,174(58.3)$ & 0.43 \\
\hline & Niger & $400(10.7)$ & 0.11 \\
\hline & Burkina Faso & $330 \quad(8.8)$ & 0.66 \\
\hline & Myanmar & $250 \quad(6.7)$ & 0.92 \\
\hline & Mali & $88 \quad(2.4)$ & 0.28 \\
\hline \multirow{5}{*}{ Lentil } & India & $983(33.5)$ & 0.71 \\
\hline & Turkey & $480(16.3)$ & 0.96 \\
\hline & Canada & $354(12.0)$ & 0.83 \\
\hline & Australia & 185 (6.3) & 1.48 \\
\hline & Nepal & 148 (6.9) & 0.82 \\
\hline \multirow[t]{5}{*}{ Peas } & France & 1,665 (16.9) & 4.93 \\
\hline & Russian Federation & $1,578(16.0)$ & 3.51 \\
\hline & Canada & $1,366(13.8)$ & 1.26 \\
\hline & China & $1,200(12.2)$ & 1.50 \\
\hline & India & $730 \quad(7.4)$ & 1.00 \\
\hline \multirow[t]{5}{*}{ Pigeonpea } & India & $2,440(81.5)$ & 0.73 \\
\hline & Myanmar & $300(10.0)$ & 0.62 \\
\hline & Malawi & $79 \quad(2.6)$ & 0.64 \\
\hline & Uganda & $78 \quad(2.6)$ & 1.00 \\
\hline & Tanzania & $47 \quad(1.6)$ & 0.71 \\
\hline \multirow[t]{5}{*}{ Soybean } & USA & $74,291(41.3)$ & 2.54 \\
\hline & Brazil & 41,903 (23.3) & 2.56 \\
\hline & Argentina & $30,000(16.7)$ & 2.63 \\
\hline & China & $16,900 \quad(9.4)$ & 1.79 \\
\hline & India & $4,270 \quad(2.4)$ & 0.75 \\
\hline
\end{tabular}

z\% of global production 
Table 6.5. Regional and world average yields of soybean, beans, peas, chickpea, broadbean, lentil, cowpea, and pigeonpea in 2002 (http://www.apps.fao.org/page/collections?subset=agriculture).

\begin{tabular}{lcccccccc}
\hline & \multicolumn{8}{c}{ Average yield $\left(\mathrm{t} \mathrm{ha}^{-1}\right)$} \\
\cline { 2 - 9 } Region & Soybean & Beans & Peas & $\begin{array}{c}\text { Chick- } \\
\text { pea }\end{array}$ & $\begin{array}{c}\text { Broad- } \\
\text { bean }\end{array}$ & Lentil & Cowpea & $\begin{array}{c}\text { Pigeon- } \\
\text { pea }\end{array}$ \\
\hline World & 2.27 & 0.68 & 1.70 & 0.79 & 1.52 & 0.81 & 0.37 & 0.72 \\
Africa & 0.91 & 0.67 & 0.55 & 0.72 & 1.36 & 0.58 & 0.35 & 0.76 \\
Asia & 1.38 & 0.54 & 1.18 & 0.78 & 1.58 & 0.77 & 0.93 & 0.72 \\
Europe & 1.88 & 1.48 & 2.99 & 0.83 & 2.39 & 0.86 & 2.95 & - \\
North Central & & & & & & & & \\
$\quad$ America & 2.54 & 1.07 & 1.32 & 1.30 & 0.79 & 0.92 & 0.78 & - \\
South America & 2.56 & 0.76 & 1.07 & 1.09 & 1.02 & 0.95 & - & 0.77 \\
Oceania & 2.12 & 1.12 & 0.57 & 0.68 & 1.39 & 1.48 & 0.43 & - \\
\hline
\end{tabular}

International trade of grain legumes also varies considerably between and within regions, both in terms of market share (Table 6.6), and the relative importance of different commodities (Tables 6.7 and 6.8) (FAO 2001). The Americas are the largest exporter of grain legumes $(89 \%$ of the 66 million t total), whereas Asia and Europe are net importers (84\% of the 65 million $\mathrm{t}$ ) despite contributing together $62 \%$ of the 55 million $t$ of global grain legume production. Soybean is the single most imported grain legume in international trade, with the bulk of soybean imports

Table 6.6. Contribution of six regions to the world trade of grain legumes in 2001 . (http://www.apps.fao.org/page/collections?subset=agriculture).

\begin{tabular}{|c|c|c|c|c|}
\hline \multirow{3}{*}{$\begin{array}{l}\text { Import } \\
\text { Region }\end{array}$} & \multicolumn{2}{|c|}{ Import } & \multicolumn{2}{|c|}{ Export } \\
\hline & $\begin{array}{l}\text { Export Quantity } \\
\text { (t) }\end{array}$ & $\begin{array}{c}\text { Value } \\
\text { (000 US \$) }\end{array}$ & $\begin{array}{l}\text { Quantity } \\
\text { (t) }\end{array}$ & $\begin{array}{c}\text { Value } \\
\text { (000 US \$) }\end{array}$ \\
\hline & $1,491,141 \quad(2.26)^{z}$ & $492,285 \quad(2.88)$ & $211,269 \quad(0.32)$ & $113,233 \quad(0.83)$ \\
\hline Asia & $31,692,800(48.03)$ & $8,793,422(51.44)$ & $2,987,635 \quad(4.49)$ & $1,171,084 \quad(8.58)$ \\
\hline Europe & $23,662,961(35.86)$ & $5,039,576(29.48)$ & $3,107,013 \quad(4.67)$ & $795,172 \quad(5.83)$ \\
\hline North & & & & \\
\hline $\begin{array}{l}\text { America } \\
\text { South }\end{array}$ & $6,332,799 \quad(9.60)$ & 1,879,334 (10.99) & $33,320,116(50.06)$ & $6,743,577(49.43)$ \\
\hline America & $2,773,543 \quad(4.20)$ & $826,899 \quad(4.84)$ & $25,802,554(38.77)$ & $4,518,207$ (33.12) \\
\hline Oceania & $30,551 \quad(0.05)$ & $64,123 \quad(0.37)$ & $1,145,230 \quad(1.72)$ & $301,348 \quad(2.21)$ \\
\hline World & $65,984,227$ & $17,093,739$ & $66,553,045$ & $13,643,063$ \\
\hline
\end{tabular}

z\% of total world trade. 
Table 6.7. Regional import statistics for seven grain legumes in 2001 (http://www.apps.fao.org/page/collections?subset=agriculture).

\begin{tabular}{|c|c|c|c|c|c|c|c|}
\hline \multirow[b]{2}{*}{ Crop } & \multicolumn{7}{|c|}{$\%$ contribution to the import of grain legumes } \\
\hline & $\begin{array}{c}\text { Total } \\
\text { import } \\
\text { value }^{z}\end{array}$ & Africa & Asia & Europe & $\begin{array}{c}\text { North } \\
\text { Central } \\
\text { America }\end{array}$ & $\begin{array}{c}\text { South } \\
\text { America }\end{array}$ & Oceania \\
\hline \multirow{2}{*}{ Beans (dry) } & $2,015,079$ & 7.21 & 34.08 & 26.50 & 19.53 & 11.98 & 0.70 \\
\hline & $3,005,236$ & 1.96 & 61.00 & 3.50 & 20.74 & 11.08 & 1.78 \\
\hline \multirow{2}{*}{$\begin{array}{l}\text { Beans } \\
\quad \text { (green) }\end{array}$} & 293,840 & 1.17 & 9.07 & 70.92 & 17.91 & 0.30 & 0.63 \\
\hline & 314,509 & 0.76 & 5.46 & 74.32 & 18.75 & 0.08 & 0.63 \\
\hline \multirow{2}{*}{$\begin{array}{l}\text { Broadbean } \\
\text { (dry) }\end{array}$} & 567,212 & 47.07 & 10.00 & 41.98 & 0.89 & 0.04 & 0.01 \\
\hline & 157,733 & 53.62 & 13.51 & 30.65 & 2.07 & 0.13 & 0.02 \\
\hline \multirow{2}{*}{$\begin{array}{l}\text { Broadbean } \\
\text { (green) }\end{array}$} & 50,034 & 4.32 & 41.76 & 50.43 & 2.43 & 0.86 & 0.10 \\
\hline & 32,172 & 3.55 & 43.77 & 50.53 & 0.93 & 0.60 & 0.61 \\
\hline \multirow[t]{2}{*}{ Chickpea } & $1,087,859$ & 10.60 & 71.95 & 13.47 & 2.13 & 1.82 & 0.03 \\
\hline & 495,885 & 14.71 & 60.27 & 19.88 & 2.47 & 2.61 & 0.63 \\
\hline \multirow[t]{2}{*}{ Lentil } & $1,097,771$ & 21.01 & 41.48 & 18.77 & 5.33 & 13.18 & 0.22 \\
\hline & 435,878 & 21.00 & 42.62 & 19.65 & 5.38 & 10.77 & 0.58 \\
\hline \multirow[t]{2}{*}{ Peas (dry) } & $3,363,995$ & 2.59 & 45.33 & 44.42 & 2.19 & 5.16 & 0.31 \\
\hline & 703,095 & 5.01 & 49.16 & 35.30 & 4.23 & 5.62 & 0.68 \\
\hline \multirow[t]{2}{*}{ Peas (green) } & 234,774 & 4.22 & 39.56 & 42.65 & 11.16 & 2.20 & 0.21 \\
\hline & 153,683 & 2.19 & 33.68 & 43.18 & 19.78 & 0.77 & 0.40 \\
\hline \multirow[t]{2}{*}{ Pigeonpea } & 2,431 & 78.98 & 1.03 & 8.51 & 11.48 & - & - \\
\hline & 1,296 & 70.22 & 8.33 & 3.70 & 17.75 & - & - \\
\hline \multirow{2}{*}{ Soybean } & $57,271,232$ & 1.09 & 48.97 & 36.16 & 9.95 & 3.82 & 0.00 \\
\hline & $11,794,253$ & 1.19 & 51.09 & 35.07 & 9.30 & 3.33 & 0.00 \\
\hline
\end{tabular}

${ }^{z}$ Figures in bold are tons and in nonbold are US \$ (000).

going to Asia and Europe (85\% of the total world-wide imports of 57 million $\mathrm{t}$ ) from the Americas, which together produce $96 \%$ of the total world-wide production of 57 million t. For chickpea, Asia is the largest producer ( $87 \%$ of 7.8 million t total world-wide production) but imports substantial quantities of the crop as well $(72 \%$ of the 1.1 million $t$ in world-wide imports), mostly from North America and Oceania.

\section{Major Constraints}

1. Diseases and Pests. Major biotic constraints to grain legume production include anthracnose in soybean, cowpea, and common bean; ascochyta blight in broadbean, chickpea, lentil, and pea; bacterial wilt in common bean, cowpea, and pea; fusarium wilt in broadbean, chickpea, 
Table 6.8. Regional export statistics for seven grain legumes in 2001 (http://www.apps.fao.org/page/collections?subset=agriculture).

\begin{tabular}{|c|c|c|c|c|c|c|c|}
\hline \multirow[b]{2}{*}{ Crop } & \multicolumn{7}{|c|}{$\%$ contributions to the export of grain legumes } \\
\hline & $\begin{array}{l}\text { Total } \\
\text { export } \\
\text { value }^{z}\end{array}$ & Africa & Asia & Europe & $\begin{array}{c}\text { North } \\
\text { Central } \\
\text { America }\end{array}$ & $\begin{array}{c}\text { South } \\
\text { America }\end{array}$ & Oceania \\
\hline \multirow[t]{2}{*}{ Beans (dry) } & $3,005,236$ & 1.96 & 61.00 & 3.45 & 20.73 & 11.08 & 1.78 \\
\hline & $1,235,643$ & 2.12 & 49.91 & 6.09 & 26.14 & 13.75 & 1.98 \\
\hline \multirow[t]{2}{*}{ Beans (green) } & 238,893 & 18.03 & 12.30 & 43.20 & 25.53 & 0.39 & 0.55 \\
\hline & 217,252 & 23.44 & 9.08 & 40.05 & 26.43 & 0.34 & 0.66 \\
\hline \multirow{2}{*}{$\begin{array}{l}\text { Broadbean } \\
\text { (dry) }\end{array}$} & 446,239 & 1.77 & 11.81 & 31.04 & 1.71 & 0.16 & 53.50 \\
\hline & 120,435 & 3.66 & 25.71 & 23.49 & 2.64 & 0.73 & 43.75 \\
\hline \multirow{2}{*}{$\begin{array}{l}\text { Broadbean } \\
\text { (green) }\end{array}$} & 74,235 & 10.08 & 36.27 & 29.94 & 22.56 & 0.26 & 0.88 \\
\hline & 51,935 & 4.75 & 33.58 & 42.86 & 16.52 & 0.39 & 1.88 \\
\hline \multirow[t]{2}{*}{ Chickpea } & 996,519 & 1.51 & 30.62 & 2.32 & 38.74 & - & 26.74 \\
\hline & 462,252 & 1.28 & 35.83 & 2.85 & 42.35 & - & 17.58 \\
\hline \multirow[t]{2}{*}{ Lentil } & $1,168,640$ & 2.24 & 26.82 & 1.74 & 50.47 & 0.02 & 18.70 \\
\hline & 462,302 & 1.50 & 41.30 & 2.25 & 40.10 & 0.02 & 14.82 \\
\hline \multirow[t]{2}{*}{ Peas (dry) } & $3,494,945$ & 0.78 & 0.33 & 28.90 & 59.40 & 0.31 & 10.27 \\
\hline & 619,592 & 1.48 & 0.65 & 29.19 & 56.85 & 0.58 & 11.24 \\
\hline \multirow[t]{2}{*}{ Peas (green) } & 120,629 & 3.18 & 17.89 & 51.92 & 26.04 & 0.95 & 0.01 \\
\hline & 77,356 & 2.93 & 21.30 & 36.62 & 36.70 & 2.40 & 0.05 \\
\hline \multirow[t]{2}{*}{ Pigeonpea } & 213 & 7.51 & 1.41 & 22.06 & 69.01 & - & - \\
\hline & 290 & 3.1 & 4.83 & 21.38 & 70.69 & - & - \\
\hline \multirow[t]{2}{*}{ Soybean } & $57,007,496$ & 0.04 & 0.64 & 2.86 & 51.80 & 44.65 & 0.01 \\
\hline & $10,396,010$ & 0.05 & 1.05 & 3.33 & 53.76 & 41.76 & 0.02 \\
\hline
\end{tabular}

${ }^{z}$ Figures in bold are tons and in nonbold are US \$ (000).

common bean, cowpea, lentil, pea, and pigeonpea; phytophthora root rot in chickpea, pigeonpea, and soybean; rust in broadbean, common bean, cowpea, lentil, and soybean; and web blight in common bean and cowpea (Table 6.9). Many of these diseases are widespread, as in the case of anthracnose, angular leaf spot, bean common mosaic virus (BCMV), and bean common mosaic necrosis virus (BCMNV), common bacterial blight, rust and web blight in common bean (Coyne et al. 2003); ascochyta blight, rust and vascular wilt in lentil (Erskine et al. 1994); ascochyta blight and fusarium wilt in chickpea (Singh et al. 1994); broomrape and chocolate spot in broadbean (Bond et al. 1994); and fusarium wilt in pigeonpea (Reddy et al. 1990). Some diseases, especially those caused by viral pathogens, are more crop and location specific. Meanwhile, among pests, nematodes (cyst, root-knot, and stem nematodes) are common in broad- 
Table 6.9. Diseases that cause substantial losses to production of soybean, beans, peas, chickpea, broadbeans, lentil, and pigeonpea.

\begin{tabular}{|c|c|c|}
\hline Crop & Disease & Common/scientific name \\
\hline \multirow[t]{3}{*}{ Broadbean } & Fungal & $\begin{array}{l}\text { Chocolate spot (Botrytis fabae Sardina); ascochyta blight } \\
\text { (Ascochyta fabae Speg.); root rot (Fusarium spp.); rust } \\
\text { [Uromyces fabae (Grev.) Fuckel = U. viciae-fabae } \\
\text { Pers.:Pers.) J. Schrot] }\end{array}$ \\
\hline & Viral & $\begin{array}{l}\text { Bean yellow mosaic virus (BYMV); bean leaf roll virus } \\
\text { (BLRV) }\end{array}$ \\
\hline & $\begin{array}{l}\text { Parasitic } \\
\text { weed }\end{array}$ & Broomrape (Orobanche crenata Forsk.) \\
\hline Chickpea & Fungal & $\begin{array}{l}\text { Fusarium wilt [Fusarium oxysporum Schlecht. Emend. Snyd. } \\
\text { F.sp. ciceris [Padwick)Snyd. \& Hans.]; ascochyta blight } \\
\text { [Ascochyta rabiei (Pass.) Lab.]; botrytis grey mold (Botrytis } \\
\text { cinerea Pers. ex Fr.); dry root rot [Rhizoctonia batanicola } \\
\text { (Taub) Butler]; phytophthora root rot [Phytophthora } \\
\text { megasperma Drechs.] }\end{array}$ \\
\hline \multirow[t]{3}{*}{$\begin{array}{l}\text { Common } \\
\text { bean }\end{array}$} & Fungal & $\begin{array}{l}\text { Angular leaf spot (Phaeoisariopsis griseola (Sacc.) Ferraris); } \\
\text { anthracnose [Colletotrichum lindemuthianum Sacc. and } \\
\text { Magn.) Scrib.]; rust (Uromyces appendiculatus (Pers) Unger } \\
\text { var. appendiculatus); root rot (Fusarium spp.); web blight } \\
\text { [Thanatephorus cucumeris (Frank) Donk (anamorph } \\
\text { Rhizoctonia solani Kuhn)] }\end{array}$ \\
\hline & Bacterial & $\begin{array}{l}\text { Common bacterial blight [Xanthomonas campestris pv } \\
\text { phaseoli (Xap)]; halo blight (Pseudomonas syringae pv. } \\
\text { Phaseolicola) }\end{array}$ \\
\hline & Viral & $\begin{array}{l}\text { Bean common mosaic virus (BCMV); bean common mosaic } \\
\text { necrosis virus (BCMNV); bean golden yellow mosaic virus } \\
\text { (BGYMV) }\end{array}$ \\
\hline \multirow[t]{4}{*}{ Cowpea } & Fungal & $\begin{array}{l}\text { Anthracnose [Colletotrichum lindemuthianum (Sacc. and } \\
\text { Magnus) Lams.-Scrib)]; septoria leaf spot (Spetoria vignae } \\
\text { P. Henn and S. vignicola Vasat Rao, S. Kozopolzanii } \\
\text { Nikolajeva); cercospora leaf spot (Cercospora canescens } \\
\text { Ellis and G. Martin); web blight (Rhizoctonia solani Kuhn); } \\
\text { Fusarium wilt [Fusarium oxysporium Schlechtend.:Fr. F. } \\
\text { sp. Tracheiphilum (E.F. Smith) W.C. Snyder and Hansen)]; } \\
\text { rust [Uromyces appendiculatus (Pers.: Pers.) Unger] }\end{array}$ \\
\hline & Bacterial & $\begin{array}{l}\text { Bacterial blight [Xanthomonas campestris pv vignicola } \\
\text { (Burkholder) Dye] }\end{array}$ \\
\hline & Viral & $\begin{array}{l}\text { Cowpea yellow mosaic virus (CYMV); Cowpea aphid-born } \\
\text { mosaic virus (CABMV) }\end{array}$ \\
\hline & $\begin{array}{l}\text { Parasitic } \\
\text { weed }\end{array}$ & $\begin{array}{l}\text { Striga [Striga gesneroioides (Wild.) Vatke)]; alectra (Alectra } \\
\text { vogelii Benth.) }\end{array}$ \\
\hline Lentil & Fungal & $\begin{array}{l}\text { Rust [Uromyces fabae (Pers.) de Bary) ( = U. vicia-fabae)]; } \\
\text { ascochyta blight [Ascochyta fabae Speg. F. sp. lentis } \\
\text { Gossen et al. (A. lentis Vassiljevsky)]; fusarium wilt [Fusar- } \\
\text { ium oxysporum f. sp. lentis (Vasudeva + Srinivas) Gordon] }\end{array}$ \\
\hline
\end{tabular}


Table 6.9. (continued)

\begin{tabular}{|c|c|c|}
\hline Crop & Disease & Common/scientific name \\
\hline \multirow{2}{*}{$\begin{array}{l}\text { Lentil } \\
\qquad \text { (cont.) }\end{array}$} & Viral & Pea seedborn mosaic virus (PSbMV) \\
\hline & $\begin{array}{l}\text { Parasitic } \\
\text { weed }\end{array}$ & Broomrape (Orobanche spp.) \\
\hline \multirow[t]{3}{*}{ Pea } & Fungal & $\begin{array}{l}\text { Ascochyta blight (Ascochyta pisi Lib.); powdery mildew } \\
\text { [Erysiphe polygoni Syd. (= E. polygoni DC.)]; downy } \\
\text { mildew [Peronospora viciae (Berk.) Casp.]; Fusarium wilt } \\
\text { (Fusarium oxysporum f. sp. pisi); common root rot } \\
\text { (Aphanomyces euteiches Drechs.); fusarium root rot } \\
\text { (Fusarium solani Kuhn) }\end{array}$ \\
\hline & Bacterial & Bacterial blight (Pseudomonas syringae Van Hall pv. pisi) \\
\hline & Viral & $\begin{array}{l}\text { Pea seedborn mosaic virus (PSbMV); Pea common mosaic } \\
\text { virus (PCMV); Pea enation mosaic virus (PEMV) }\end{array}$ \\
\hline \multirow[t]{2}{*}{ Pigeonpea } & Fungal & $\begin{array}{l}\text { Fusarium wilt (Fusarium udum Butler); phytophthora blight } \\
\text { [Phytophthora dreschsleri Tucker f. sp. cajani (Pal, Grewal } \\
\text { and Sarbhoy) Kannaiyan, Riberio, Erwin and Nene] }\end{array}$ \\
\hline & Viral & Sterility mosaic virus (SMV) \\
\hline \multirow[t]{3}{*}{ Soybean } & Fungal & $\begin{array}{l}\text { Frogeye leaf spot (Cercospora sojina); sudden death } \\
\text { syndrome [Fusarium solani (Mart.) Sacc. f. sp. glycines]; } \\
\text { anthracnose (Colletotrichum truneatum); phytophthora rot } \\
\text { (Phytophthora sojae Kaufmann and Gerdemann); brown } \\
\text { stem rot (Philalophora gregata); white mold (Sclerotinia } \\
\text { sclerotiorum); stem canker [(Diaporthe phaseolorum var. } \\
\text { sojae Athow.)]; rust (Phakopsora pachyrhizi H. Sydow and } \\
\text { Sydow); purple seed stain (Cercospora kikuchii) and } \\
\text { phomopsis seed decay (Phomopsis spp. and Diaporthe } \\
\text { phaseolorum var. sojae) }\end{array}$ \\
\hline & Bacterial & Bacterial blight (Pseudomonas syringae pv. Glycinea) \\
\hline & Viral & $\begin{array}{l}\text { Soybean mosaic virus (SMV); Peanut mottle virus (PMV); } \\
\text { Yellow mosaic virus (YMV); soybean leaf crinkle virus } \\
(\mathrm{SLCV})\end{array}$ \\
\hline
\end{tabular}

bean, chickpea, pea, pigeonpea, and soybean; legume pod borer is particularly troublesome in chickpea, pigeonpea, and soybean; aphids in broadbean, chickpea, cowpea, peas, and lentil; maruca pod borers are major constraints in cowpea, lentil, and pigeonpea; bruchids in chickpea and common bean; and weevils in common bean, cowpea, and pea (Table 6.10). Most of these pests are not as widely distributed as some of the diseases cited above. Apart from pests and diseases, parasitic weeds are found in cowpea, broad bean, and lentil and include striga, alectra, and broomrape. The diseases and pests are reported to cause substantial losses to production. For example, the total losses due to disease for the 
Table 6.10. Insect pests that cause substantial losses to production of soybean, beans, peas, chickpea, broadbean, lentil, and pigeonpea.

\begin{tabular}{|c|c|c|}
\hline Crop & Insect pests & Common/scientific name \\
\hline \multirow[t]{2}{*}{ Broadbean } & Field pest & Aphids (Aphis fabae Scop.) \\
\hline & Nematode & $\begin{array}{l}\text { Stem nematode [Ditylenchus dipsaci (Kuhn) Filipjev]; } \\
\text { pea cyst nematode (Heterodera goettingiana Liebscher) }\end{array}$ \\
\hline \multirow[t]{3}{*}{ Chickpea } & Field pest & $\begin{array}{l}\text { Pod borer (Helicoverpa armigera Hubner); leaf miner } \\
\text { (Liriomyza cicerina Rond.); aphids (Aphis craccivora } \\
\text { Koch.) }\end{array}$ \\
\hline & Storage pest & Bruchid beetles (Callosobruchus chinesis L.) \\
\hline & Nematode & $\begin{array}{l}\text { Cyst nematode (Heterodera ciceri Vovlas, Greco and Di } \\
\text { Vito); root-knot nematode [(Meloidogyne arneria (Neal) } \\
\text { Chitwood; } M \text {. incognita (Kofoid and White) Chitwood; } M \text {. } \\
\text { javanica (Treub) Chitwood] }\end{array}$ \\
\hline \multirow{2}{*}{$\begin{array}{l}\text { Common } \\
\text { bean }\end{array}$} & Field pest & Leaf hoppers (Empoasca spp) \\
\hline & Storage pest & $\begin{array}{l}\text { Bruchids (Zabrotes subfasciatus Boheman and } \\
\text { Acanthoscelides obtectus (Say) }\end{array}$ \\
\hline \multirow[t]{3}{*}{ Cowpea } & Field pest & $\begin{array}{l}\text { Aphids (Aphis crassivora Koch); thrips (Megalurothrips } \\
\text { sjostedti Trybom); maruca pod borer (Maruca testulalis } \\
\text { Geyer); pod sucking bug (Clavigralla spp, Anoplocnemis } \\
\text { curvipes Fabricius, Riptortus dentipes Fabricius, and } \\
\text { Nizara viridula L.) }\end{array}$ \\
\hline & Storage pest & Weevil (Callosorbruchus maculates Fabricius) \\
\hline & Nematode & $\begin{array}{l}\text { Root-knot nematode [Meloidgyne incognita Kofoid and } \\
\text { White; M. javanica (Treub) Chitwood)] }\end{array}$ \\
\hline Lentil & Field pest & $\begin{array}{l}\text { Aphids (Aphids craccivora Koch. and Acyrthosiphon } \\
\text { kondoi Shinji); pod borer (Etiella zinkenella Treritschke); } \\
\text { Bruchids (Callosobruchus chinensis Linn. and C. } \\
\text { maculates Fabricius) }\end{array}$ \\
\hline \multirow[t]{2}{*}{ Pigeonpea } & Field pest & $\begin{array}{l}\text { Pod borer [Helicoverpa armigera and Maruca vitrata } \\
\text { Geyer]; pod fly (Melanagromyza obtuse Malloch); pod } \\
\text { wasp (Tanaostigmodes cajaninae La Salle) }\end{array}$ \\
\hline & Nematode & $\begin{array}{l}\text { Root-knot nematode [Meloidogyne javanica (Treub) } \\
\text { Chitwood and M. incognita (Kofoid and White) } \\
\text { Chitwood]; reniform nematode (Rotylenchulus reniformis } \\
\text { Linford and Oliveira); cyst nematode (Heterodera cajani } \\
\text { Koshy) }\end{array}$ \\
\hline \multirow[t]{2}{*}{ Pea } & Field pest & Pea weevil (Bruchus pisorum L.) \\
\hline & Nematode & $\begin{array}{l}\text { Pea cyst nematode (H. goettingiana Liebscher); root- } \\
\text { knot (Meloidogyne spp.) nematode }\end{array}$ \\
\hline \multirow[t]{2}{*}{ Soybean } & Field pest & $\begin{array}{l}\text { Mexican bean beetle [Epilachna varivestes (Mulsant)]; } \\
\text { corn earworm (Helicoverpa zea Boddie); soybean looper } \\
\text { [Pseudoplusia includens (Walker)]; velvetbean caterpillar } \\
\text { [Anticarsia gemmatalis (Hubner)]; Bean fly } \\
\text { (Melenagromyza sojae) }\end{array}$ \\
\hline & Nematode & $\begin{array}{l}\text { Soybean cyst (Heterodera glycines Ichinohe), root-knot } \\
\text { (Meloidogyne spp) }\end{array}$ \\
\hline
\end{tabular}


1994 soybean harvested in the 10 highest country producers were estimated to be 15 million tons valued at US \$3.3 billion (Wrather et al. 1997). Soybean cyst nematode caused the greatest reduction in yield followed by stem canker, brown spot, and charcoal rot. Cowpea is a major legume grown in West African semi-arid areas, and striga is reported to cause an average $30 \%$ reduction in crop yield in susceptible varieties (Aggrawal and Ouedraogo 1989), whereas attacks from Maruca pod borer can result in up to $80 \%$ yield losses (Singh et al. 2003b).

Diseases are also a constraint to the production of good-quality seeds in legumes. In soybean, for example, phomopsis seed decay reduces seed germination, seed weight, and oil quality (Bradley et al. 2002; Wrather et al. 2003); soybean mosaic virus or peanut mottle virus infection reduces seed germination and vigour, also further increasing susceptibility to phomopsis seed decay (Koning et al. 2001; Gore et al. 2002); fusarium spp. infection reduces seed weight and volume, increasing total oil content but decreasing the linoleic and linolenic acid composition (Wilson et al. 1995; Meriles et al. 2002); and sclerotinia stem rot reduces seed germination, seed weight, and also changes oil quality (Hoffman et al. 1998). In pea, ascochyta blight induces a premature water loss from hulls and leaves, accelerates seed desiccation, alters carbohydrate metabolism and content, as well as protein remobilization and free amino acid translocation, and reduces seed weight and total carbohydrate and nitrogen contents (Garry et al. 1996). Similarly, in chickpea, ascochyta blight also reduces seed weight and protein content (Gaur and Singh 1996).

2. Environmental Stress. The major abiotic factors affecting common bean, cowpea, lentil, and soybean production are drought and high temperature stress, while low temperatures are an additional constraint in chickpea and lentil production areas. Other abiotic constraints of importance are ozone stress in common bean, non-availability of iron in calcareous soils in soybean, while aluminium (Al) toxicity and low availability of phosphorus in acid soils are a common limiting factor for a range of grain legumes. Many tropical soils, including those of the acid savannas of Africa and Latin America, are low in available phosphorus due to high compositions of iron and aluminum oxides (Weir 1972, 1977). Some legume crops have adapted to these soils by becoming more nutrient efficient, often with specialized root traits that contribute to a superior ability to acquire nutrients (Sanginga et al. 2003). For example, piscidic acid and its derivatives exuded from pigeonpea roots enhance the ability of this legume to access phosphorus that is bound to iron (Ae et al. 1990; Ishikawa et al. 2002). This phosphorus-solubilizing activity has been associated with superior growth of pigeonpea and peanut under deficient conditions (Ae and Shen 2002). 


\section{Variation in Legume Genomes}

Legumes form a coherent taxonomic group with frequent and widespread macro- and microsynteny. However, comparative legume genomics is far behind that of the cereals but is beginning to provide an insight into genome size, gene clustering, genome duplication, distribution of repetitive elements (Young et al. 2003) as well as gene order and sequence conservation across genera (Young et al. 2003; Choi et al. 2004a). There is huge variation in nuclear genome size of legume species, ranging from 370 million base pair (Mbp) in Lablab niger to 13,000 Mbp in Vicia faba (Arumugunathan and Earle 1991; http://www.rbgkew.org.uk/cval/homepage.html). Meanwhile, the two model legumes, $L$. japonicus and $M$. truncatula, have relatively compact genomes of approximately $470 \mathrm{Mbp}$. In terms of the genome size variation for the major legume crops focused upon in this review, urd bean or black gram [Vigna mungo (L.) Hepper], mung bean [Vigna radiata (L.) R. Wilczek], common bean, lima bean (Phaseolus lunatus L.), tepary bean (Phaseolus acutifolius A. Gray), and cowpea have the smallest genomes (574 Mbp to $647 \mathrm{Mbp}$ ); pigeonpea (784, $882 \mathrm{Mbp}$ ) and chickpea $(738 \mathrm{Mbp}$ ) have slightly larger genomes; soybean has a relatively large genome (1,115 Mbp); while pea and lentil (4,063 Mbp to 4,397 $\mathrm{Mbp})$ and broad bean $(12,603 \mathrm{Mbp})$ have massive genome sizes. The largest legume genomes are characterized by extensive abundance of retroelements (Murray et al. 1978, 1981; Pearce et al. 1996; Flavell et al. 1992; Neumann et al. 2001). When compared to the genome of Arabidopsis thaliana, whole genome duplication and segmental duplications appear to have played a significant role in creating new diversity in higher plants, including the legumes (Arabidopsis Genome Initiative 2000; Vision et al. 2000).

The case of the soybean genome is of particular interest as a polyploid model system because it allows the study of both palaeopolyploidy and neopolyploidy. 'Diploid' Glycine species are all $2 \mathrm{n}=4 \mathrm{x}=38$ or 40 , in contrast to its allies in the legume tribe Phaseoleae, most of which are all $2 \mathrm{n}=20$ or 22 (Goldblatt 1981). The genome duplication that led to this change in chromosome number is evident in the modern soybean genome (Zhu et al. 1994; Shoemaker et al. 1996), and is estimated to have taken place around 15 Mya (Schlueter et al. 2004). Doyle et al. (2004) have shown that the various polyploid taxa known from the subgenus Glycine are all part of a single large allopolyploid complex, linked by shared diploid genomes. Many elements of the complex have arisen recently, and most show evidence of recurrent origins. However, there are also many dissimilarities among even closely related polyploids. 
Polyploids differ from one another in terms of the number of original polyploidization events, the amounts of allelic diversity harboured at different loci, bidirectional vs. unidirectional origins, retention of ribosomal gene homoeologues, success as measured by geographical range and abundance, and patterns of gene expression. Comparative mapping has provided a means for detecting and mapping large numbers of duplicated loci and integrating maps generated using different populations. In Glycine soja, RFLP mapping data from nine mapping populations has been used to reveal that large portions of the soybean genome seem to have undergone duplication in more than one round of duplication events (Shoemaker et al. 1996). In that study, the size of the homoeologous segments ranged from 1.5 to $106.4 \mathrm{cM}$, with an average size of 45.3 $\mathrm{cM}$, and segments were present in as many as six copies, with an average of 2.55 duplications per segment. The presence of nested duplications suggests that at least one of the original genomes may have undergone an additional round of polyploidization, thus accounting for the highly duplicated nature of the G. soja genome.

More detailed background information has been reviewed elsewhere for genetic markers and plant genetic resources (Bretting and Widrlechner 1995; Haussman et al. 2004); legume phylogeny, genetic transformation, nutritional quality, product development and utilization (Anonymous 2003; Wojciechowski 2003); model legumes (Anonymous 2003); and on genetic resources, breeding, and genomics of individual legume crops: soybean (Hymowitz et al. 1998; Boerma and Specht 2004; Stacey and Nguyen 2004); common bean (Singh 2001; Broughton et al. 2003; Kelly et al. 2003; McClean et al. 2004); cowpea (Hall et al. 1997; Kelly et al. 2003); chickpea (Kumar and Abbo 2001; Weeden and Muehlbaur 2004); pea (Myers et al. 2001; Weeden and Muehlbaur 2004); lentil (Weeden and Muehlbaur 2004); grasspea (McCutchan 2003); and peanut (Dwivedi et al. 2003; Holbrook and Stalker 2003; Paterson et al. 2004).

\section{AVAILABLE GENETIC RESOURCES OF KEY LEGUME CROPS}

\section{A. Tropical Legumes}

1. Phaseolus vulgaris (Common Bean). Common bean is the most widely grown Phaseolus species in the world (Singh 1992) and among all grain legumes is used for direct human consumption at the highest level (Broughton et al. 2003). Common beans are grown worldwide in many different countries and regions over a wide range of latitudes (from $40^{\circ}$ 
$\mathrm{S}$ in Chile to $60^{\circ} \mathrm{N}$ in Scandanavia) and altitudes (up to 3000 masl $=$ meter above sea level). The crop is found in many agroecosystems, from the tropical highlands of Central and South America to the subtropical belts of South-east Brazil, Southern Africa, and India to the temperate regions of Europe and North America (Debouck 1991; Singh 1992).

Common beans were domesticated from wild populations of $P$. vulgaris that were annual climbing vines growing at mid-altitudes (1500-2000 masl) in forest clearings or disturbed environments from northern Mexico to northern Argentina (Toro et al. 1990). The primary gene pool of common bean comprises both cultivars and wild populations, and hybrids between these two groups are fully fertile (Singh et al. 1995). Domestication occurred in two separate centers of origin, giving rise to two distinct gene pools: the Andean gene pool from the Andean region of South America and the Mesoamerican gene pool from Central America. These differ particularly in terms of seed size, Andean cultivars being large seeded ( $>40$ g 100-seed weight ${ }^{-1}$ ) and Mesoamerican cultivars being small seeded ( $<25$ g 100-seed weight ${ }^{-1}$ ) (Evans 1973, 1980). Growth habit, photoperiod insensitivity, pod fiber, seed dormancy, and seed weight were also influenced during the domestication of common beans (Evans 1980; Smartt 1988; Gepts and Debouck 1991).

The Andean and Mesoamerican gene pools can be divided into six races based on agro-ecological adaptation and seed types (Singh et al. 1991), including the Mesoamerican races, Durango, Jalisco, and Mesoamerica, and the Andean races, Chile, Nueva Grenada, and Peru. There is also additional diversity within Mesoamerican races, especially a group of Guatemalan climbing bean accessions that are not grouped with any of the previously defined races (Beebe et al. 2000). In addition, the gene pools and races overlap in many regions. During pre-Colombian times in northern South America, both Andean and Mesoamerican beans grew together, allowing some hybridization to occur between the genepools (Amirul-Islam et al. 2004). The crop's dispersal into other regions of the world, especially Europe and Africa, started with Spanish and Portuguese colonization of the New World and allowed even further diversification along with additional opportunities for genepool mixing. Significant adaptative evolution also occurred in the Middle East, South Asia, Southeast Asia, and China.

Common bean is grown for a variety of purposes and is harvested as a dry grain or as a fresh vegetable (either as snap beans or as greenshelled beans). Dry beans have a huge range of commercial classes based on seed size, color, and pattern and there are many established varieties for each class. Dry bean cultivars differ in growth habit (determinate bush to indeterminate climbing bean), phenological traits such as growth cycle (60 to 330 days), seed shape and size (10 to 100 g per 100 seed 
weight), seed coat color (from white, creams, yellows, pinks, reds, purples to blacks with many different mottled, speckled, or two-tone patterns), and canning and cooking qualities (Voysest and Desert 1991; Singh 1992). Snap beans, in contrast, possess a thick succulent mesocarp and low or absent fiber in the green pod walls and sutures (Myers and Baggett 1999; Myers 2000). The different market classes of the snap bean cultivars are largely determined on the basis of pod shape (flat, cylindrical, or oval), color (dark green, light green, yellow, or purple), and length. Among snap bean cultivars, there can be substantial variation in growth habit and adaptation traits, although snap beans are postulated to be a more recent selection from dry beans based on the stringless pod character and other horticultural traits (Singh 1992).

\section{Phaseolus coccineus (Scarlet Runner Bean) and Phaseolus poly-} anthus (Year-long Bean). Scarlet runner bean and year-long bean are closely related domesticates and, along with the wild relative $P$. costaricensis Freytag and Debouck, belong to the secondary gene pool of common bean. Scarlet runner bean and year-long bean have a more limited distribution than common bean and are grown mostly in mid-elevation areas of Central America and northern South America and small parts of the Caribbean (Jamaica, Puerto Rico), Europe (Portugal, Spain, and the United Kingdom), and Africa (Ethiopia, Kenya, and South Africa). They are all vigorous climbing beans adapted to cooler highlands above 800 masl except for some improved varieties that can be shrubs growing at lower elevations in cool climates. Traditionally, both species were intercropped with maize but they are also grown on trellises, fences, or walls. White seeded types of $P$. coccineus are preferred in most commercial settings, but the seed coat color and pattern can vary substantially in this species, although most are large-seeded (60 or more g per 100 seed). The seed of $P$. polyanthus is often yellow, tan, white, or reddish brown.

Scarlet runner bean was domesticated from wild accessions of $P$. COCcineus, which grew in a region from Mexico to Colombia. In contrast, wild accessions of year-long bean are only found in a small region of Guatemala and Mexico (Freytag and Debouck 2002). Out-crossing of both scarlet runner bean and year-long bean has introgressed large amounts of genetic diversity (Hawkins and Evans 1973). Crosses with common bean are also successful but only when common bean is used as the female parent (Ibrahim and Coyne 1975; Manshardt and Bassett 1984; Singh et al. 1997). Scarlet runner beans and year-long beans are good sources of disease resistance that can be readily transferred to common bean given their cross-compatibility. However, they also convey poor vine growth habit, late maturity, low pod set, and reduced yield. 
3. Phaseolus acutifolius (Tepary Bean). Tepary bean belongs to the tertiary gene pool of common bean and is a minor crop grown sporadically in the dry regions of Northwest Mexico, Southwestern United States, and Central America (Singh 1992). Tepary beans are very drought tolerant and are planted in either desert washes or late in the rainy season to rely on residual soil moisture (Pratt and Nabhan 1988). Domestication was thought to have occurred about 5000 years ago in or near the Sonoran desert of Northwest Mexico, from where the crop spread north and south as recently as 1200 years ago (Pratt and Nabhan 1988; Debouck 1991). Tepary beans are divided into two clades, $P$. acutifolius var. acutifolius and P. acutifolius var. tenuifolius; however, the exact source of the domesticate is unknown (Garvin and Weeden 1994). The most closely related wild species is $P$. parvifolius Freytag. The two cultivated forms are distinguished on the basis of leaflet shape: var. acutifolius accessions have obovate to subovate leaflets whereas var. tenuifolius accessions have linear leaflets (Pratt and Nabhan 1988).

Allozyme and phaseolin analyses failed to reveal diversity at the molecular level (Schinkel and Gepts 1988, 1989), which may suggest a narrow genetic base in tepary bean.

Indeed, Garvin and Weeden (1994) have observed that cultivated tepary beans are less diverse than common beans and that there appears to have been little introgression from wild relatives since domestication. Tepary beans are known to have a very low natural crossing rate that limits the creation of new diversity within the crop and consequently its genetic potential. Almost all cultivated tepary beans have similar seed size (10 to 20 g per 100 seed) and growth habits, usually a sprawling indeterminate semi-prostrate habit (Debouck 1991). In addition, the range of seed colors in the cultigen is limited to white, cream, and yellow, with or without black or purple flecking (Debouck 1991). Tepary beans are cross compatible with common bean but require embryo rescue to produce viable offspring (Mejiá-Jiménez et al. 1994).

4. Phaseolus lunatus (Lima Bean). Lima bean is fairly distinct from the rest of the cultivated Phaseolus species and is grown mainly in dry regions under irrigation or as a horticultural crop. As with common bean domestication, lima beans were first cultivated in both the Andean and Mesoamerican regions, leading to large-seeded and small-seeded types of gene pools, respectively (Maquet et al. 1997; Fofana et al. 1997). Although not a major commodity in international trade, lima beans are an important horticultural crop in several countries in the Americas and Europe, although, as a grain crop, lima beans are grown on a very small scale as a backyard crop in Latin America (Debouck 1991). The presence of cyanogenic glucosides in some cultivars of lima beans has prevented 
their wide use as a dry grain except when properly processed. The growth habit of lima beans varies from a short-season indeterminate bush to perennial vigourous climbers. Some cultivars of lima beans are relatively tolerant to heat, drought, and salinity stresses (Bayuelo-Jimenez et al. 2002).

Lima beans are considered as diverse as common beans given that landraces are found over a wide area of the Neo-tropics; however, diversity is highest in the large seeded types and lower in the small seeded types (Gutierrez-Salgado et al. 1995). Although they are predominantly an inbreeding crop, lima beans can undergo moderate outcrossing, and have introgressed substantial diversity through crosses between the gene pools and between large-seeded types and wild forms in South America (Maquet et al. 1997). However, similarly to common beans, overall diversity may be greater in wild than in cultivated lima beans (GutierrezSalgado et al. 1995). In addition, like common beans, lima beans have a great range of seed colors and patterns, some of which are very attractive and unusual. Lima beans vary widely in seed size (from 16 to 280 g per 100 seed), with Andean 'Big Lima' types larger than Mesoamerican 'Sieva' or Caribbean 'Potato' types (Gutierrez-Salgado et al. 1995). Horticultural varieties within the determinate Fordhook (Andean) and Henderson (Mesoamerican) classes are generally closely related and well established in the United States (Nienhuis et al. 1987).

The closest wild relatives to lima beans are P. filiformis, $P$. augusti, and $P$. angustissimus. Neither lima beans nor any of these wild species have been successfully crossed with common beans, therefore these species would be considered to be in the quarternary gene pool of the common bean (Debouck 1991).

Centro Internacional de Agricultura Tropical (CIAT) at Cali (Colombia) holds, under an agreement with the Food and Agricultural Organization of the United Nations (FAO), the largest number of Phaseolus germplasm (a total of 41,061 accessions, including 26,500 accessions of cultivated common beans, 1,300 of wild common beans, 1,000 from the secondary gene pool, and 350 from the tertiary gene pool) (Debouck 1999). Other institutions holding sizeable Phaseolus germplasm collections are the United States Department of Agriculture, Agricultural Research Service (USDA-ARS), Western Regional Plant Introduction Station, Pullman, WA, United States (with 11,809 primary, 475 secondary, and 121 tertiary gene pool accessions); the Instituto Nacional de Investigaciones Forestales y Agropecuarias, Pecuar, Mexico (10,570 cultivated and 600 wild accessions of common bean); the Vavilov Institute of Plant Industry (VIR), St. Petersburg, Russia (9,762 accessions); the Institut fur Pflanzengenetik und Kulturpflanzenforschung (IPK), Gaterslaben, Germany (7,609 accessions); the National Biological Institute, 
Bogor, Indonesia (3,846 accessions); and the Punjab Agricultural University, Ludhiana, India (3,000 accessions); as well as other national programs in Latin America, Africa, Europe, and Asia. The European Phaseolus database contains 31,717 accessions, the largest from Phaseolus vulgaris (http://www.agrobio.bmlf.gv.at/phaseolus).

5. Vigna radiata (Mung Bean). Mung bean was domesticated in India (Vavilov 1926) from its wild ancestral form V. radiata var. sublobata (Chandel et al. 1984), a widely distributed species found in areas stretching from Central and East Africa, Madagascar, through Asia, New Guinea, to Northern and Eastern Australia (Tateishi 1996). There are three botanical varieties: $V$. radiata var. radiata, the cultivated form (mung bean); var. sublobata (Roxb.), the wild ancestral form of mung bean; and var. setulosa, another wild form distributed in India, Indonesia, and southern China (Marechal et al. 1978). Compared to its wild relatives, mung bean has pale yellow flowers, smaller pockets on the keel, longer pods, and pods that attach at the side or bottom of the peduncle. Cultivars exhibit diverse colours of mature pods (black, brown, or pale gray) and seeds (yellow, greenish yellow, light green, shiny green, dark green, dull green, black, brown, and green mottled with black). Var. sublobata has many desirable attributes such as resistance to bruchid and yellow mosaic virus (Singh and Ahuja 1977), high methionine content in the seed (Babu et al. 1988), higher photosynthesis efficiency, and tolerance to drought (Ignacimuthu and Babu 1987), and high tolerance to saline and alkaline soils (Lawn et al. 1988).

The Asian Vegetable Research and Development Centre (AVRDC) in Taiwan maintains 5,108 mung bean accessions from 51 countries. Other institutions holding sizeable collections are the USDA-Southern Regional Plant Introduction Station, Griffin, GA, United States (3,494 accessions); and the National Bureau of Plant Genetic Resources (NBPGR), New Delhi, India (2,789 accessions).

6. Vigna mungo (Urd Bean or Black Gram). Urd bean was domesticated in India from its wild ancestral form, Vigna mungo var. silvestris Lukoko, Marechal and Otoul (Zeven and de Wet 1982), and is confined to cultivation in South Asia and adjoining regions (India, Pakistan, Afghanistan, Bangladesh, the Philippines, and Myanmar). There are two botanical varieties: var. mungo (the cultivated form) and var. silvestris (the wild ancestor) (Lukoki et al. 1980). Compared to its wild relative, black gram has bright yellow flowers, longer pockets on the keels, shorter pods, pods attached upright to the peduncle, and dull black seed color. However, shiny black and shiny green seeded black gram has also been reported from Nepal. 
The National Bureau of Plant Genetic Resources (NBPGR) maintains about 2,100 accessions of which 829 are active collections, while the AVRDC maintains a collection of around 200 accessions.

7. Vigna angularis (Adzuki Bean). Adzuki bean is an important crop in East Asia. It consists of two botanical varieties: var. angularis (Willd.) Ohwi and Ohashi, the cultivated form; and var. nipponensis Ohwi and Ohasi, the presumed wild form of adzuki bean (Marechal et al. 1978). An intermediate weedy or semi-wild adzuki also exists (Yamaguchi 1992). The wild and weedy adzuki beans are believed to be widely distributed in Asia (Yamaguchi 1992). The greater genetic variation in the wild and weedy relatives of adzuki bean (Xu et al. 2000a,b) suggests they may be useful for crop improvement. $V$. angularis is primarily autogamous but a significant percentage of cross pollination has been reported (Lumpkin and McClary 1994). Wild adzuki bean is fully fertile in crosses with the cultigen (Siriwardhane et al. 1991), thus it can be directly used in breeding programs. However, introgression of desirable traits from wild germplasm is usually confounded by deleterious linkage drag. Intermediate weedy or semi-wild adzuki beans are, therefore, better alternatives for breeding programs than wild adzuki beans because they closely resemble the cultigen, while offering greater variation than the cultigen.

The world collection of adzuki bean consists of a large number of landraces maintained in national gene banks, mainly in China, Japan, and Korea, while NBPGR in India maintains 194 accessions of adzuki bean.

8. Vigna umbellata (Rice Bean). Rice bean was domesticated in Southeast Asia, and wild forms are distributed across northern India, Burma, Thailand, Laos, and Vietnam (Ohashi et al. 1988). There are two recognized botanical varieties in rice bean: Vigna umbellata var. umbellata (the cultivated type) and $V$. umbellata var. gracilis (the wild ancestor). Morphologically, rice bean is similar to adzuki bean. It has golden yellow flowers, pods attached to the peduncle downward, and slender seeds with protruding hilums. There are many agricultural types and varieties of rice bean, with seed color ranging from ivory to greenish ivory, red violet, and black (Chatterjee and Dana 1997). NBPGR in India holds 1,081 rice bean accessions.

9. Vigna aconitifolia (Moth Bean or Meat Bean). Moth bean is a native to India, Pakistan, and Burma (Rachie and Roberts 1974). It has a short, compact plant habit, and is widely grown for food in the arid and semiarid regions of India. NBPGR in India maintains 702 accession of moth bean. 
10. Vigna unguiculata (Cowpea). Cowpea was domesticated in Africa, and this is the only continent where wild forms exist and it is the location of the greatest genetic diversity. Pasquet (1993a,b, 1997) divides cowpea into 10 perennial subspecies and one annual subspecies (ssp. unguiculata). The annual subspecies is differentiated into two botanical varieties: var. unguiculata (cultivated cowpea) and var. spontanea (Schweinf.) Pasquet (annual wild cowpea). Accessions of the 11 subspecies have been classified into three groups according to their breeding systems: perennial outcrossing accessions, perennial outcrossing and inbreeding accessions, and annual inbreeding accessions (Pasquet 1994). The perennial outcrossing accessions look primitive and are more remote from each other and from inbreeding taxa. The perennial outcrossing taxa include ssp. baoulensis (A. Chev.) Pasquet, ssp. aduensis Pasquet, and ssp. pawekiae Pasquet. The perennial outcrossing and inbreeding taxa include ssp. dekindtiana (Harms) Verdic. sensu stricto; ssp. stenophylla (E. Mey.) Verdc.; ssp. tenuis (E. Mey.) Marechal, Mascherpa and Stainier; ssp. alba (G. Don) Pasquet; and ssp. pubescens (R. Wilczek) Pasquet. The annual inbreeding taxa include ssp. unguiculata var. spontanea (Schweinf.) Pasquet and var. unguiculata. Within this large gene pool, mainly made of perennial taxa, cultivated cowpea (ssp. uniguiculata var. unguiculata) form a genetically coherent group and are closely related to annual cowpeas (ssp. unguiculata var. spontanea), which may include the most likely progenitor of cultivated cowpea (Pasquet 1999).

The International Institute of Tropical Agriculture (IITA), Ibadan, Nigeria holds, under an agreement with FAO, 14,816 cultivated and 1,651 wild cowpea germplasm accessions from 84 countries characterized for up to 30 agro-botanical traits revealing diverse growth habit, variable pod length, pod shape, seed size, and seed-coat colors (Ng and Singh 1997). More than 50 wild Vigna species from more than 50 countries are represented in this collection. NBPGR in India holds 2,499 cowpea accessions in its gene bank.

11. Vigna subterranea (Bambara Groundnut). Bambara groundnut is an indigenous grain legume from West Africa (Hepper 1963) that is grown by subsistence farmers in drier parts of sub-Saharan Africa where the soils are too poor for cultivation of other favored legumes such as common beans and peanut. It is tolerant to drought, and its seeds are highly nutritious. Bambara cultivars are differentiated by the ratio of petiole length to internode length: bunch (8.1-11.0), semi-bunch (7.0-8.0), and open (4.4-6.5) (Doku 1969; Karikari 1972) or by the canopy diameter at 100 days after planting (bunch $-<40 \mathrm{~cm}$, semi-bunch $-40-80 \mathrm{~cm}$, and open $\longrightarrow 80 \mathrm{~cm}$ ) (Ezedinma and Maneke 1985). Pasquet and Fotso (1997) 
classified the domesticated Cameroonian landraces based on seeds per pod: single seeded pods (northern group) and two to four seeds per pod (southern group). The domesticated bambara groundnut has a compact growth habit, whereas wild types produce long vines (Hepper 1963). The freshly dug fruits of domesticated bambara groundnut possess thick fleshy pods that wrinkle upon drying, but the fruits of wild germplasm have thin pods that do not wrinkle upon drying. Seeds of wild accessions are small, uniform in size, and 9-11 mm long, while the seeds of domesticated accessions are 11-15 $\mathrm{mm}$ in length. Petioles of leaves of wild plants are much shorter and not as erect or closely tufted, and more slender than those of domesticated types (Hepper 1963). The wild and domesticated bambara groundnuts are characterized by a low total genetic diversity and a comparatively high intra-population diversity, which suggests that they are predominantly autogamous. High genetic identity between wild and domesticated forms suggests that wild bambara groundnuts are the true progenitor of the domesticated bambara groundnut (Pasquet et al. 1999). IITA maintains 2,029 bambara groundnut accessions in its gene bank following an agreement with FAO.

The European Vigna database contains 4,000 accessions (http:// www.agrobio.bmlf.gv.at/vigna); the largest collection is from VIR, St. Petersburg, Russia.

12. Glycine max (Soybean). The genus Glycine is divided into two subgenera: Glycine and Soja. The subgenus Glycine contains 16 wild perennial species (Burridge and Hymowtiz 1997) that are indigenous to Australia with diverse morphological features and genomes, variable chromosome numbers (13 wild species $2 \mathrm{n}=40$; G. tabacina: $2 \mathrm{n}=40$ or 80, and G. tomentella: 2n $=38,40,78$, or 80 ) but representing an invaluable source of economically important traits such as resistance to biotic and abiotic stresses. The subgenus Soja is composed of G. max (L.) Merrill, the cultivated soybean $(2 \mathrm{n}=40)$, and its wild annual counterpart, G. soja Sieb. and Zucc. $(2 \mathrm{n}=40)$. The genetic base of soybean is extremely narrow (Gizlice et al. 1993, 1994, 1996; Burton 1997). Harlan and de Wet (1971) catagorised the genetic resources into three main gene pools, based on cross compability with the cultigen and value in plant breeding. The primary gene pool (GP1) consists of soybean cultivars and landraces $(G$. $\max$ ) as well as their wild annual progenitor (G. soja), all of which readily intercross producing vigorous fertile hybrids that exhibit normal meiotic behavior and gene segregation. GP1 is divided into two subspecies: subspecies A (cultivated races) and subspecies B (spontaneous races). The secondary gene pool (GP2) has yet to be fully defined but the tertiary gene pool (GP3) comprises very diverse germplasm including the 16 wild perennial species of the subgenus Glycine that are 
geographically isolated from G. $\max$ and G. soja. Crosses between primary and tertiary gene pools fail to produce viable progeny so gene transfer between these two gene pools is not possible or requires radical techniques (Harlan and de Wet 1971).

Soybean genetic resources in Japan are classified into eight groups based on days to flowering and days from flowering to maturity, whereas soybean genetic resources in North America are classified into 13 maturity groups based on their relative time of maturity.

There are 100,000 G. max accessions held in germplasm collections around the world, of which less than 10,000 are G. soja accessions, and 3,500 are accessions of wild perennial Glycine species (Palmer et al. 1995). The institutions holding large numbers of soybean germplasm are the Institute of Crop Germplasm Resources, Beijing, China (15,334 accessions); the National Seed Storage Laboratory, Fort Collins, CO, United States (14,379 accessions of G. $\max$ and 1,102 G. soja accessions); the AVRDC, Taiwan (12,916 accessions); IITA, Nigeria (2,500 accessions), and the Commonwealth Scientific and Industrial Research Organization (CSIRO), Canberra, Australia (2,000 accessions). The European Glycine database consists of 11,915 accessions from eight countries, the largest from Russia and Germany (Vishnyakova and Omelchenko 2001).

13. Cajanus cajan (Pigeonpea). The genus Cajanus has six sections: Cajanus, Atylia Benth, Fruticosa van der Maesen, Cantharospermum (W. \& A.) Benth, Volubilis van der Maesen, and Rhyncosoides Benth, comprising a total of 32 species (van der Maesen 1985). Taxonomically, the genera Atylosia, Dunbaria, and Rhynchosia are very close to cultivated pigeonpea. Morphological, cytological, and chemo-taxonomical data revealed that these three genera are congeneric, therefore all 28 species of Atylosia and one species each of Rhynchosia (R. acutifolia) and Dunbaria (D. heynei) have been recently merged into Cajanus. Further taxonomic studies revealed that $A$. cajanifolia is the closest species to pigeonpea compared to the successively more distant species: A. lineata, A. scarabaeoides, A. sericea, A. albicans, A. volubilis, A. platycarpa, and R. Rothii (Pundir and Singh 1985).

The pigeonpea gene pool consists of the cultigens in GP1; C. acutifolius, C. albicans, C. cajanifolius, C. lanceolatus, C. latisepalus, C. lineatus, C. reticulatus, C. scarabaeoides, C. sericeus, and C. trinervius in GP2; and C. goensis, C. heynei, C. kerstingii, C. mollis, C. platycarpus, C. rugosus, C. volubilis, and other Cajaninae (e.g., Rhynchosia, Dunbaria, and Eriosema) in GP3 (Smartt 1990).

The International Crops Research Institute for the Semi Arid Tropics (ICRISAT), Patancheru, India holds under an agreement with FAO 13,548 pigeonpea germplasm accessions including 555 wild accessions from 74 
countries. Other institutions holding substantial amounts of pigeonpea germplasm include the NBPGR $(5,454$ accessions) in India and the USDA, Southern Regional Plant Introduction Station $(4,116)$ in USA.

14. Arachis hypogaea (Peanut or also known as groundnut). The genus Arachis has been divided into nine sections: Arachis, Caulorhizae, Erectoides, Extranervosae, Heteranthae, Procumbentes, Rhizomatosae, Trierectoides, and Triseminatae (Krapovickas and Gregory 1994) which include diploid ( $2 \mathrm{n}=2 \mathrm{x}=20$ ), tetraploid $(2 \mathrm{n}=4 \mathrm{x}=40)$, and aneuploid $(2 \mathrm{n}=2 \mathrm{x}=18)$ species. There are four gene pools in peanut. The primary gene pool consists of landraces of Arachis hypogaea and its wild form $A$. monticola; the secondary gene pool consists of diploid species from section Arachis that are cross-compatible with A. hypogaea; the tertiary gene pool includes species in section Procumbentes that are weakly cross-compatible with $A$. hypogaea; and the quaternary gene pool comprises all remaining wild Arachis species across seven other sections that are completely incompatible with the cultigen (Singh and Simpson 1994).

Cultivated peanut germplasm is classified into two main subspecies: hypogaea (no flowering on the main stem and alternate branching) and fastigiata (flowering on the main stem and sequential branching). The subsp. hypogaea contains two botanical varieties: hypogaea (common name: Virginia) and hirsuta. The subsp. fastigiata contains four botanical varieties: fastigiata (common name: Valencia), peruviana, aequatoriana, and vulgaris (common name: Spanish). All six botanical varieties have unique morphological characteristics that separate them from one another (Krapovickas and Gregory 1994).

ICRISAT holds, under an agreement with FAO, 14,966 accessions of cultivated peanut and 453 accessions of wild Arachis species (representing nine sections and 44 species) from 93 countries. Other institutions holding a large number of peanut accessions are the National Research Center for Groundnut, Junagadh, India (7,935 accessions) and the USDA Southern Regional Plant Introduction Station, USA (6,233 accessions). In the United States, wild Arachis species are maintained at North Carolina State University, Raleigh (250 accessions) and at the Texas Agricultural Experiment Station, TAMU, Texas (300 accessions).

\section{B. Temperate Legumes}

1. Pisum sativum (Pea). The genus Pisum is comprised of two species: P. sativum and P. fulvum (Polhill and van der Maesen 1985). P. sativum is then divided into the subspecies ssp. sativum and spp. elatius. Cultivated $P$. sativum ssp. sativum has been further divided into var. sativum (that contains the horticultural types), and var. arvense (that contains 
fodder and winter pea types). Subspecies elatius is comprised of var. elatius, var. pumilio, and var. brevipedunculatum (Smartt 1990). Crosses between $P$. sativum and $P$. fulvum are successful but only when the latter is used as the pollen parent.

The major gene banks holding pea germplasm are the John Innes Center, Norwich, UK (5,000 accessions); the Nordic Genebank, Alnarp, Sweden (5,000 accessions); the Vavilov Institute of Plant Industry, St. Petersburg, Russia (5,500 accessions); the USDA Regional Plant Introduction Station, Geneva, NY, United States (2,800 accessions); the USDA National Seed Storage Laboratory, Fort Collins, CO, United States (2,213 accessions); the Institute de Germoplasma, Bari, Italy (4,090 accessions); the Tropical Forage Crop Genetic Resources Center, Queensland, Australia (3,300 accessions); and NBPGR in India (2,721 accessions). The European Pisum database consists of 35,775 accessions from 18 countries, the largest from Russia and Italy (Ambrose 2001).

2. Vicia faba (Broad/Faba Bean). The genus Vicia is a large genus comprised of more than 130 species (Smartt 1990). Vicia faba, the cultivated species, is assigned to the sub-genus Vicia and placed together with $V$. narbonensis L., V. hyaeniscyamus Mouterde, V. galilaea Plitm. and Zohary, $V$. johannis Tamamschian, and $V$. bithynica L. in section Faba of that sub-genus (Ladizinsky et al. 1988; Smartt 1990). Its wild progenitor has not yet been discovered but $V$. faba var. paucijuga, smallseeded types still grown in Afghanistan and northwest Kashmir, seems the closest to the wild form. However, V. faba appears to be reproductively isolated from other Vicia species. $V$. faba has two subspecies: ssp. faba L. and ssp. paucijuga Murat. $V$. faba subsp. faba has three varieties: var. minor Beck, var. equina Pers., and var. faba L. (Maxted 1993).

The International Center for Agricultural Research in the Dry Areas (ICARDA) maintains two types of germplasm collections for this crop: the international legume faba bean (ILB) collection (original germplasm accessions being heterogeneous populations maintained as composite bulks) and the faba bean pure line (BPL) collection (derived from the ILB collection but maintained by pure-breeding of single-plant progeny rows). The ICARDA gene bank holds, under an agreement with FAO, 4,453 ILB and 5,248 BPL accessions from 30 countries (Robertson 1997). A catalogue containing 840 BPL lines describes useful accessions for various traits (Robertson and El-sheerbenny 1988). Other institutions holding large amounts of broadbean germplasm are the Institute de Germoplasma, Bari, Italy (3,671 accessions); the Vavilov Institute of Plant Industry, St. Petersburg, Russia (2,525 accessions); the Institute of Crop Genetic Resources, Beijing, China (1,999 accessions); the Institut 
fur Pflanzengenetik und Kulturpflanzenforschung (IPK), Gaterslaben, Germany (1,300 accessions); and the Ethiopian Genebank, Addis Ababa, Ethiopia (1,298 accessions). The European Vicia database has 13,000 accessions, with $52 \%$ of European origin (Duc et al. 2001).

3. Lens culinaris (Lentil). The genus Lens is comprised of four species: L. culnaris, L. odemensis, L. nigricans, and L. ervoides. L. culnaris has two subspecies: ssp. culinaris, the cultivated lentil, and ssp. orientalis, the closest wild relative (Ladizinsky 1993). Subspecies culinaris has two varieties: var. microsperma (small-seeded lentils) and var. macrosperma (large-seeded lentil) (Barulina 1930). Based on cross-compatibility, the genus Lentil forms two groups: L. culinaris / L. odemensis and L. ervoides /L. nigricans. Of the wild lentils, the putative ancestor of the cultigen $L$. culnaris ssp. orientalis is a member of the crop's primary gene pool, whereas L. odemensis and L. ervoides constitute the secondary gene pool (Ladizinsky 1993).

ICARDA holds, under an agreement with FAO, 7,477 germplasm accessions from 64 countries, and published a catalogue containing 4,550 accessions (Erskine and Witcombe 1984). Other institutions maintaining substantial amounts of lentil germplasm include the Vavilov Institute of Plant Industry, St. Petersburg, Russia (2,358 accessions); the USDA Western Regional Plant Introduction Station (2,259 accessions); and NBPGR $(2,212)$. The European Lens database consists of 1,675 accessions from seven countries, the largest from Turkey and Spain (Acikgoz 2001).

4. Cicer arietinum (Chickpea). The genus Cicer is comprised of 34 wild perennial, eight wild annual, and one cultivated annual (Cicer arietinum) species (van der Maesen 1987). Ladizinsky and Adler (1976) grouped six annual Cicer species into three distinct groups based on cross-compatibility with cultivated chickpea (Cicer arietinum): The primary gene pool (GP1) consists of Cicer arietinum, C. reticulatum, and C. echinospermum; the secondary gene pool (GP2) consists of $C$. judaicum, C. pinnatifidium, and C. bijugum; and the tertiary genepool (GP3) consists of only one species, C. cuneatum. Hybridizations within the groups are possible but with variable success, while crosses between members of different groups are not successful. There is no barrier to gene flow between $C$. arietinum and $C$. reticulatum of GP1, while it is much more difficult to produce hybrids with $C$. echinospermum.

Two distinct forms of chickpeas have evolved since domestication: "desi" types characterized by small seeds that are angular and pigmented and "Kabuli" types characterized by large seeds that have a rounded 
appearance and lack pigmentation. The desi types are primarily grown in South Asia and the kabuli types in the Mediterranean region.

ICRISAT, under an agreement with FAO, holds 17,188 cultivated and 58 wild accessions of Cicer species, whereas ICARDA, following the same FAO agreement, maintains 9,628 cultivated and 263 wild accessions. Other institutions holding chickpea germplasm are the NBPGR, India (14,566 accessions); CLIMA (4,351 accessions) and AusPGRIS (7922 accessions) in Australia; USDA (4,662 accessions); and the Seed and Plant Improvement Institute, Keraj, Iran (4,925 accessions). The European Cicer database consists of 3,700 cultivated accessions from 11 countries, the largest from Turkey and 75 wild accessions from 13 Cicer species (Pereira et al. 2001).

5. Lathyrus sativus (Grasspea). Grasspea is an important pulse crop in South Asia and China that is very tolerant to drought. It has a very hardy and penetrating root system that enables it to grow on a wide range of soil types (Campbell et al. 1994). There are two main groups in the genus Lathyrus: Group 1 consists of blue flowered types from South-west Asia, South Asia, and Ethiopia, while Group 2 consists of white, or white and blue flowered types distributed around the Mediterranean basin (Jackson and Yunus 1984). The genus Lathyrus has 160 species and 45 subspecies (Allkin et al. 1986). The species are separated into 13 sections based on morphological traits (Kupicha 1983), and L. sativus is grouped in the section Lathyrus with 33 other species. The other sections in the genus Lathyrus are Clymenum and Linearicarpus. In taxonomic studies, Lathyrus species clustered into three distinct groups, which correlated with the three sections. L. gorgoni and L. cicera from the section Lathyrus are most similar to the cultigen L. sativus (Croft et al. 1999). The species in section Lathyrus include both annual and perennial forms. Lathyrus sativus has been placed in the primary gene pool, L. amphicarpos and L. cicera in the secondary gene pool, and the remaining species in the tertiary gene pool (Yunus and Jackson 1991).

Excessive consumption of grasspea causes a neurological disorder in humans and livestocks called lathyrism, a non-reversible paralysis of the lower limbs that is due to $\beta$-N-oxalyl-L- $\alpha, \beta$-diaminopropionic acid or ODAP (Bell 1964; Murti et al. 1964). Genetic variation in ODAP content is reported among lathyrus germplasm accessions (Kaul et al. 1986).

Institutions holding Lathyrus germplasm are Jawaharlal Nehru Agricultural University, Jabalpur, India (503 accessions); ICARDA (100 accessions); and the USDA Western Regional Plant Introduction Station, USA (300 accessions). Grain legume collection in Hungary and Bulgaria contains 509 (Holly 2001) and 320 (Angelova 2001) Lathyrus accessions, respectively. 


\section{Model Species Related to Grain Legumes}

1. Medicago truncatula Gaertn. (Barrel Medic). Barrel medic is a forage legume commonly grown in Australia, which originated in the Mediterranean basin, and is closely related to the extensively grown forage legume, alfalfa (M. sativa L.). The National Plant Germplasm System in the United States holds 320 accessions of barrel medic assembled from the Mediterranean basin, Eastern Europe, and the Caucasus. The Australian Medicago Genetic Resource Center has assembled 5,284 accessions from 38 countries, and INRA (Institut National de Recherche Agronomique), France, has assembled more than 300 natural populations collected from 9 countries (http://www.naaic.org/Publications/ 1998Proc/abstracts/Prosperi2.html). M. truncatula has emerged as a model plant for legume genomic studies (see section VI A).

2. Lotus japonicus (Miyakogusa). Miyakogusa (also known as capital weed) was first recognized at the ancient capital city of Kyoto, in Japan. A number of accessions have been collected from northernmost Hokkaido island to the southernmost Miyakojima island in Japan, and these are conserved at Miyazaki University, which has the mandate to collect, conserve, and distribute $L$. japonicus genetic resources. Like $M$. truncatula, the L. japonicus has also emerged as a model plant for legume genomic studies (see section VI A).

\section{MANAGEMENT AND UTILIZATION OF LEGUME GENETIC RESOURCES}

Plant genetic resources are the basic raw materials required to meet the current and future needs of crop improvement programs. For effective legume genetic resource management, several steps are needed: (A) enriching the genetic resources through collections or new germplasm and creation of new genetic variability, (B) conserving and regenerating genetic resources, and (C) characterizing, evaluating, and documentating genetic diversity. The development of core collections has been shown to be a particularly powerful strategy for providing crop breeding programs with a systematic yet manageable entry point into global germplasm resources.

\section{A. Collection and Enhancement}

Botanical and ethno-botanical prospecting and collecting have been the principal methods by which legume genetic resources have been accumulated in gene banks around the world. Collecting expeditions have 
usually targeted major production regions (markets and farmers' fields) and/or primary and secondary centers of diversity (natural environments where wild relatives are found). Eco-geographical, social, or economic targeting, along with local interviews, together with an appreciation of biological factors (crop maturity, seed set) have been used to help decide on the most propitious areas and times for collecting. Passport data and expedition numbers are usually assigned while collecting and germplasm entries are cleaned, checked for seed viability, and placed in medium-length to long-term storage. In addition to collecting expeditions, germplasm exchange between gene banks and with local organizations has also provided an effective mechanism for the accumulation of genetic resources.

\section{B. Regeneration and Conservation}

The need for regeneration may arise any time after a collection is made. Sample size and reproduction system (self or cross pollination) are the key factors that have influenced the genetic integrity of original samples. Increasing the size of the original sample used for multiplication usually ensures better genetic integrity of the accessions. Since leguminous crops have papilionaceous flowers (i.e., the male and female parts are enclosed within petals), cleistogamy is commonly forcing a high level of self-pollination in many legume species. However, flower structures of crops such as broadbean and pigeonpea are relatively looser and when insects visit the flowers cross-pollination can be common. To ensure selfing in these crops during regeneration, plants are covered with thin cloth bags or individual germplasm lines are grown in isolation. Especially in mixed samples of self-pollinated crops or in populations of cross-pollinated crops, every effort should be made to conserve the entire genetic variability found in the original sample. In this respect, retaining larger seed samples is likely to preserve a greater proportion of the genetic variation. Since legumes have orthodox seeds (Roberts 1973) that can be dried to low seed moisture content (about 5-7\%) and conserved effectively, they are usually easy to store under controlled conditions. However, it is important to ensure phytosanitary health and long-term germination. The seeds are dried in cool and dry conditions to reduce the moisture $(5 \pm 1 \%)$ to a desired level and then stored as active ( 0 to $\left.4^{\circ} \mathrm{C}, 20-30 \% \mathrm{RH}\right)$ and base $\left(-18^{\circ}\right.$ to $\left.-20^{\circ} \mathrm{C}\right)$ collections (IBPGR 1976). Extremely dry conditions (below 5\%) can have a more detrimental effect on the large-seeded legumes species (such as common bean, faba bean) than on small-seeded legume species and should be avoided (Suzuki 2003). Seeds with high oil content generally have lower 
and shorter viability in storage than those with low oil content, thus requiring more frequent regeneration (Ellis et al. 1990).

\section{Characterization, Evaluation, and Documentation}

Characterization of germplasm is a critical factor for the efficient management and utilization of genetic resources. Precise assessment of the genetic relationships among ex situ conserved accessions should allow gene bank curators to eliminate duplicates, form a core collection, acquire new germplasm, initiate genetic and evolutionary studies, and efficiently manage and conserve genetic resources. The presence of duplicate accessions within collections is a burden to gene banks and their users. The increasing size of collections and the decreasing available resources have stimulated gene banks to identify and remove redundant germplasm in order to increase the efficiency of conservation and utilization (van Hintum and Visser 1995; van Hintum and Knupffer 1995; van Hintum et al. 1996; van Treuren et al. 2001). The first stage of characterization is the evaluation of descriptor traits that are diagnostic, generally highly heritable, and usually easily scored in discrete classes. The second stage of characterizing germplasm is evaluation of other traits considered desirable by the breeders, farmers, and consumers of that particular crop. Characters such as plant height, flowering and maturity time, number of branches, number of fruits or yield can all indicate agronomic worth of an accession. Descriptors for chickpea (IBPGR, ICRISAT, and ICARDA 1993), peanut (IBPGR and ICRISAT 1992), broadbean (IBPGR 1983b), grasspea (IPGRI 2000), lentil (IBPGR 1985a), pigeonpea (IBPGR and ICRISAT 1993), Phaseolus (USDA 1998), common bean (IBPGR 1982; INIA, IPGRI, and MADRP 2001a), lima bean (INIA, IPGRI, and MADRP 2001b), scarlet runner bean (IPGRI 2003), tepary bean (IBPGR 1985b), soybean (IBPGR 1984), cowpea (IBPGR 1983a), mung bean (IBPGR 1980), and bambara groundnut (IPGRI, IITA, and BAMNET 2000), as well as multi-crop passport descriptors as listed (http://www.ipgri.cgiar.org), provide an important framework for characterization of legume genetic resources for various morphophysiological, reproductive, and biochemical traits. The passport, characterization, and evaluation data should be easily accessible to the users in a searchable format that readily assists the selection of desired germplasm. The use of the SQL software package has been very helpful for streamlining entry, storage, and retrieval of information on genetic resources. However, the development of complex query systems and decision support tools will greatly enhance the future utilization of the germplasm collection. 
While a germplasm curator or botanist can readily evaluate germplasm for basic descriptors, further evaluation for grain quality, resistance to pests and diseases, tolerance to abiotic stresses, and molecular genetic characterization requires diverse specialized skills. The estimates of genetic relationships can be useful for organizing germplasm for conservation of genetic resources, for the identification of cultivars, for selection of parents for hybridization, for predicting favorable heterotic combinations, and for reducing the number of accessions needed to ensure sampling of a broad range of genetic variability. Molecular characterization of germplasm is a particularly useful tool for assisting gene bank curators to better manage genetic resources, helping them to identify redundant germplasm and to provide users with the most diverse germplasm for applications in research and breeding (Bretting and Widrlechner 1995; Virk et al. 1995; Brown and Kresovich 1996; van Treuren et al. 2001). Accessions with the most distinct DNA profiles are likely to contain the greatest number of novel alleles. It is in these accessions that one is likely to uncover the largest number of unique and potentially agronomically useful alleles. This strategy has resulted in the identification of a significant number of new and agronomically useful quantitative trait loci (QTL) alleles in wild germplasm of rice and tomato (Tanksley and McCouch 1997). Molecular markers also facilitate the genetic mapping of important traits that plant breeders can then use to enhance the power and efficiency of their selection (see section V B). Marker-assisted introgression of agronomic traits from germplasm to elite cultivars offers powerful new mechanisms for efficient use of genetic resources in crop breeding programs (Haussmann et al. 2004).

Morphological traits, isozymes, and DNA-based genetic markers are routinely used to measure genetic relatedness among germplasm. However, the conflicting results obtained from different assays illustrate that these relationships are far from simple (Moser and Lee 1994; Powell et al. 1996; Tatineni et al. 1997; Dillmann et al. 1997; Schut et al. 1997; Crouch et al. 2000; Jordan et al. 2003; Soleimani et al. 2002; Hamza et al. 2004). This is not surprising, as the traits and genomic regions reflected by various morphological and molecular markers can be under very different profiles and intensities of natural and artificial selection. However, in contrast to phylogenetic analysis, for effective germplasm utilization diversity assessments need to capture variation in as many loci of potential agronomic importance as possible. Thus, characterizing germplasm with a variety of both morphological and molecular markers is likely to provide the best estimate of genetic diversity if a precise level of differentiation is required for selection of germplasm. 


\section{Core Collection}

Yield improvement in most legume crops has lagged behind the cereals, even where yield increases have occurred, as in the case of chickpea productivity in India, which steadily increased from 482 to $780 \mathrm{~kg} \mathrm{ha}^{-1}$ from 1951 to 2000 (Ali and Kumar 2003). Similarly, soybean yield increased in the USA from 1690 to $2561 \mathrm{~kg} \mathrm{ha}^{-1}$ from 1961 to 2000 (FAO 2003). Thus, legume yield appears to have reached a plateau and the lack of further significant progress is a cause for concern. One reason for the stagnation or complete absence of progress is that legume breeders have tended to confine themselves to crosses within their working collection, consisting largely of highly adapted materials, and rarely use more diverse germplasm sources. For instance, in 24 years (1978 to 2001) the chickpea breeders at ICRISAT involved only 801 germplasm but 11,383 pre-bred materials in hybridization that resulted in 3430 advanced breeding lines. Similarly, in India's chickpea program, a nursery of 184 breeding lines evaluated in 2001 included 284 cultivars and breeding lines in their pedigrees but only 13 gene bank accessions (mostly for stress resistance) as parents. This is obviously only a small fraction of the available germplasm diversity of over 17,000 chickpea accessions in ICRISAT's gene bank.

Core collections present a manageable and cost-effective entry point into germplasm collections for identifying parental genotypes with new sources of disease and pest resistance or abiotic stress tolerance. Screening of core collections is usually the most efficient and reliable means of carrying out an initial search of the germplasm collections. Evaluation of larger amounts of germplasm through multi-location trials is both very expensive and time consuming, while large-scale generation of accurate and precise evaluation data from such trials is generally not possible to dramatically reduce the probability of identifying desirable material. Core collections are usually constituted from the $10 \%$ of the entire germplasm collection that represents $90 \%$ of the collections variability (Brown 1989). These representative subsample collections are developed from the entire collection, using all available information on accessions including the origin and geographical distribution plus characterization and evaluation data. Ten percent of most crop germplasm collections are a much more feasible amount of material for intensive and precise evaluation. In this way, the development of a core collection has the advantage of displaying much of the variability conserved in the gene bank in a limited number of accessions, allowing a researcher to identify new sources of resistance to new isolates or biotypes of diseases and pests at a substantially lower cost than evaluating the full 
collection. In some cases this approach will not lead to the identification of many new sources of favourable genetic variation. Nevertheless, evaluation of the cluster representatives captured by the core collection then provides an efficient means of identifying which areas of the entire germplasm collection warrant more extensive evaluation in the search for more genetic variation associated with the target trait. Core collections also serve as an excellent mechanism for transferring genetic diversity from the primary centers of diversity of a crop to secondary centers. Core collections are available for chickpea, pigeonpea, peanut, common bean, mung bean, pea, lentil, and cowpea (Table 6.11). Most core collections have been designed from global or regional collections held within international agricultural research centers or national program gene banks, while a few have also been developed for wild accessions (Tohme et al. 1996).

In legume crops with over 10,000 accessions, even a core collection could be unmanageably large, so a further reduction is also valuable, providing it is not associated with losing too much of the spectrum of diversity. Thus, Upadhyaya and Ortiz (2001) developed a strategy for sub-sampling a core collection to develop a mini-core collection, again based on selecting $10 \%$ of the accessions representing $90 \%$ of the variability of the larger collection. In this process, the core collection is evaluated for various morphological, agronomic, and quality traits to select a subset of $10 \%$ of accessions from this core subset (i.e., $1 \%$ of the entire collection) that captures a large proportion (i.e., more than $80 \%$ of the entire collection) of the useful variation. Selection of core and minicore collections is based on standard clustering procedures used to separate groups of similar accessions, combined with various statistical tests to identify the best representatives. The mini-core collection for chickpea consisted of 211 accessions, while the peanut mini-core consists of 184 accessions (Table 6.11).

Core or mini-core germplasm collections have been used for identifying a range of germplasm with beneficial traits for use in breeding programs. Both germplasm curators who manage gene banks as well as plant breeders who use germplasm in improvement programs have benefited from the development of legume core collections that represent the large variability in the germplasm collections of any given gene bank. Some examples of the benefits of using core collections are described below:

1. Peanut. When 20 agronomic traits were evaluated on 504 accessions of the Asian peanut core collection in multi-location environments, 60 diverse accessions were identified that could be used to broaden the 
Table 6.11. Description of core collections of chickpea, common bean, cowpea, peanut, mungbean, pigeonpea, pea, and lentil.

\begin{tabular}{|c|c|c|c|c|c|}
\hline \multirow[b]{2}{*}{ Crop } & \multicolumn{2}{|c|}{$\begin{array}{l}\text { Size and extent of } \\
\text { characterization of } \\
\text { original collection }\end{array}$} & \multicolumn{2}{|c|}{ Core collection } & \multirow[b]{2}{*}{ Reference } \\
\hline & $\begin{array}{l}\text { Accessions } \\
\text { (No.) }\end{array}$ & $\begin{array}{l}\text { Traits } \\
\text { (No.) }\end{array}$ & Description & $\begin{array}{l}\text { Accessions } \\
\text { (No.) }\end{array}$ & \\
\hline \multirow[t]{3}{*}{ Chickpea } & 16,991 & 13 & Core & 1,956 & $\begin{array}{l}\text { Upadhyaya et al. } \\
\text { 2001a }\end{array}$ \\
\hline & 1,956 & 22 & Minicore & 211 & $\begin{array}{l}\text { Upadhyaya and } \\
\text { Ortiz } 2001\end{array}$ \\
\hline & 3,315 & - & Core & 505 & Hannan et al. 1994 \\
\hline \multirow{4}{*}{$\begin{array}{l}\text { Common } \\
\text { bean }\end{array}$} & 388 & 47 & Iberian core & 52 & Rodino et al. 2003 \\
\hline & 157 & 14 & Netherlands core & 31 & Zeven et al. 1999 \\
\hline & 975 & - & $\begin{array}{l}\text { CIAT wild } \\
\text { species core }\end{array}$ & 114 & Tohme et al. 1996 \\
\hline & 24,000 & - & $\begin{array}{l}\text { CIAT cultivated } \\
\text { core }\end{array}$ & 1,420 & Tohme et al. 1995 \\
\hline Cowpea & 10,227 & - & Core & 2,078 & IITA 2002 \\
\hline Lentil & 2,390 & - & Core & 287 & $\begin{array}{l}\text { Simon and Hannan } \\
1995\end{array}$ \\
\hline Mungbean & 1,532 & 38 & Core & 152 & Bisht et al. 1998 \\
\hline Pea & 2,886 & - & Core & 505 & $\begin{array}{l}\text { Simon and Hannan } \\
1995\end{array}$ \\
\hline \multirow[t]{4}{*}{ Peanut } & 14,310 & 14 & Core & 1,704 & $\begin{array}{l}\text { Upadhyaya et al. } \\
2003\end{array}$ \\
\hline & 1,704 & 31 & Minicore & 184 & $\begin{array}{l}\text { Upadhyaya et al. } \\
2002\end{array}$ \\
\hline & 4,738 & 15 & Asian core & 504 & $\begin{array}{l}\text { Upadhyaya et al. } \\
\text { 2001c }\end{array}$ \\
\hline & 7,432 & 24 & USDA core & 831 & $\begin{array}{l}\text { Holbrook et al. } \\
1993\end{array}$ \\
\hline Pigeonpea & 12,153 & 14 & Core & 1,290 & Reddy et al. 2004 \\
\hline
\end{tabular}

genetic base of cultivars (Upadhyaya et al. 2004). In addition, 10 new diverse sources of early maturity (landraces) that were as early as the earliest maturing control (Chico) but produced 25 to 36\% more pod yield than in the early maturing, widely adapted cultivar JL 24 (ICRISAT 2002b). Further evaluation of the peanut core identified five accessions that showed tolerance to low temperature but produced higher pod yield (Upadhyaya et al. 2001b). Incorporation of cold tolerance and early maturity into improved genetic background would extend peanut cultivation 
in the Indian north plains. Evaluation of the USDA peanut core collection (Holbrook et al. 1993) identified two accessions that showed 90\% less root-knot nematode damage (Holbrook et al. 2000).

2. Chickpea. Evaluation of a chickpea core collection resulted in identification of accessions that had maturity dates similar to those of the early maturing control cultivar but higher seed yields than commercial controls (ICRISAT 2002b). Accessions showing drought (Krishnamurthy et al. 2003) and salinity (Serraj et al. 2004) tolerance have also been identified in the chickpea core and chickpea mini-core collections, respectively. The drought-tolerant accessions had deeper roots than drought-tolerant control cultivar (Krishnamurthy et al. 2003).

3. Pea. Screening of a pea core collection for Fusarium wilt resistance identified 62 accessions with resistance to race 2, 39 accessions with resistance to race 1 , and one of wild progenitors with resistance to both races (McPhee et al. 1999). Fusarium root rot (Fusarium solani f. sp. pisi) is another economically important fungal disease of pea in most peagrowing areas around the world. Screening of the pea core collection identified 44 accessions with partial resistance to Fusarium root rot, with a disease severity rating of 2.5 or less on a 0 to 5 scale (where $5=$ completely rotted) (Grunwald et al. 2003).

4. Lentil. When the lentil core collection of 577 germplasm accessions was evaluated for resistance to vascular wilt disease, six accessions showed $\leq 5 \%$ wilted plants in comparison to $100 \%$ wilted plants in the susceptible control (Sarker et al. 2001). From the USDA lentil core collection of 287 accessions (Simon and Hannan 1995), accessions with high grain and fodder yields were identified for use in breeding programs (Tullu et al. 2001)

5. Common Bean. Eleven new sources of resistance to white mold were reported when Miklas et al. (1999) evaluated a subset of the USDA common bean core collection. Similarly, Mahuku et al. (2003) identified 32 accessions that were resistant to angular leaf spot in the CIAT common bean core collection, which had also been screened by Islam et al. (2002) for anthracnose and common bacterial blight resistance.

\section{E. Elite Germplasm, Genetic Stock, and Cultivar}

It is beyond the scope of this review to provide a detailed summary of the literature related to improved grain legumes breeding lines and cul- 
tivars. However, analysis of 24 years (1980-2003) of scientific literature published in the journal Crop Science revealed 570 articles on new grain legume genetic resources, including the registration of grain legume germplasm (102 publications), genetic stocks (12 publications), and cultivars (456 publications). Among the species represented, soybean ranked first with 325 publications, followed by common bean (120), chickpea (38), cowpea (27), pea (24), lentil (17), and pigeonpea (9). Two recent review articles provide a detailed description of the genetic resources of peanut and their utilization in crop improvement programs (Dwivedi et al. 2003; Holbrook and Stalker 2003).

Grain legume germplasm and cultivars possess many desirable attributes that have been introgressed into improved genetic backgrounds. For example, germplasm releases or cultivars exist for soybean with variation in seed size (large or small seeded types) and seed composition (high protein content, low oil content, altered fatty acids, low in oligosaccharide, deficient in lipoxygenase isozyme and trypsin inhibitor); for chickpea, pigeonpea, and pea germplasm with high protein content; for pea and lentil with varying cotyledon color (yellow, green and/or red); for common bean and pea with excellent canning quality; for soybean, cowpea, chickpea, pigeonpea, pea, lentil, and common bean with varying degrees of resistance to pests (defoliators, aphids, leaf minor, and nematodes) or diseases (fungal, bacterial, and viruses) and tolerance to drought and/or high temperature; for soybean with resistance to lodging, iron chlorosis, and pod shattering; and for soybean and common bean with adaptation to wide and narrow planting systems.

In addition, herbicide tolerant (wild perennial Glycine species) and special-purpose soybeans (for sprouts and fermented products); cold and salinity tolerant chickpea; winter-hardy peas; double-podded chickpeas and peas; leafless peas; genetic or cytoplasmic male sterile pigeonpea and soybean; and extra early-maturing chickpea and common bean are now available that may be used in breeding programs to incorporate these beneficial traits into new genetic backgrounds.

\section{F. Wild Species Germplasm}

Wild species of grain legumes harbor beneficial alleles and genes for improvement of grain quality and yield, resistances to pests and diseases, and tolerance to environmental stresses (Table 6.12). For example, wild relatives have provided resistance to nematodes in pigeonpea, chickpea, and soybean; to Ascochyta blight in chickpea, lentil, and pea; to weevils in common bean, rice bean, and pea; to bruchids in cowpea, chickpea, mung bean, and rice bean; to Fusarium wilt, leaf miner, botrytis gray 
Table 6.12. Wild species relatives of grain legume crops reported to possess agronomically beneficial traits.

\begin{tabular}{|c|c|c|c|}
\hline Crop & Trait & Wild species & Reference \\
\hline \multirow[t]{14}{*}{ Chickpea } & \multicolumn{3}{|c|}{ Pest and disease resistance } \\
\hline & Fusarium wilt & $\begin{array}{l}\text { C. bijugum, C. judiacum, C. reticulatum, C. echinospermum, } \\
\text { C. pinnatifidum, C. canariense, C. chorassanicum, C. cuneatum, } \\
\text { and C. montbreti }\end{array}$ & $\begin{array}{l}\text { Infantino et al. 1996; Croser } \\
\text { et al. 2003; Rao et al. } 2003\end{array}$ \\
\hline & Cyst nematode & C. bijugum, C. pinnatifidum, and C. reticulatum & $\begin{array}{l}\text { Sharma et al. 1994; Vito et al. } \\
\text { 1996; Rao et al. } 2003\end{array}$ \\
\hline & Root-knot nematode & C. judiacum, C. pinnatifidum, C. chorassanicum, and C. cuneatum & Sharma et al. 1994 \\
\hline & Leaf miner & $\begin{array}{l}\text { C. reticulatum, C. echinospermum, C. pinnatifidum, } \\
\text { C. chorassanicum, C. bijugum, C. judiacum, and C. cuneatum }\end{array}$ & Croser et al. 2003 \\
\hline & Bruchid & $\begin{array}{l}\text { C. reticulatum, C. echinospermum, C. pinnatifidum, C. bijugum, } \\
\text { C. judiacum, and C. cuneatum }\end{array}$ & Croser et al. 2003 \\
\hline & Bortytis gray mold & C. bijugum and C. pinnatifidum & $\begin{array}{l}\text { Stevenson and Haware 1999; } \\
\quad \text { Rao et al } 2003\end{array}$ \\
\hline & $\begin{array}{l}\text { Ascochyta blight } \\
\text { and Fusarium wilt }\end{array}$ & C. judiacum, C. bijugum, C. pinnatifidum & Stamigna et al. 2000 \\
\hline & Ascochyta blight & $\begin{array}{l}\text { C. reticulatum, C. echinospermum, C. pinnatifidum, C. bijugum, } \\
\text { C. judiacum, C. cuneatum, and C. montbreti }\end{array}$ & $\begin{array}{l}\text { Croser et al. 2003; Rao et } \\
\quad \text { al. } 2003\end{array}$ \\
\hline & Phytophthora & C. echinospermum & $\begin{array}{l}\text { Croser et al. 2003; Knights } \\
\text { et al. } 2003\end{array}$ \\
\hline & \multicolumn{3}{|l|}{ Agronomic characters } \\
\hline & Cold tolerance & $\begin{array}{l}\text { C. reticulatum, C. echinospermum, C. pinnatifidum, C. bijugum, } \\
\text { C. judiacum, and C. microphyllum }\end{array}$ & Croser et al. 2003 \\
\hline & Drought tolerance & C. microphyllum & Croser et al. 2003 \\
\hline & High seed protein & C. bijugum and C. reticulatum & Rao et al. 2003 \\
\hline
\end{tabular}




\begin{tabular}{|c|c|c|c|}
\hline \multirow{4}{*}{$\begin{array}{l}\text { Common } \\
\text { bean }\end{array}$} & \multicolumn{3}{|l|}{ Pest resistance } \\
\hline & Mexican bean weevil & Wild P. vulgaris & Acosta-Gallegos et al. 1998 \\
\hline & \multicolumn{3}{|l|}{ Agronomic characters } \\
\hline & Salinity & $\begin{array}{l}\text { P. micranthus, } P \text {. mcvaughii, } P \text {. lunatus, } P \text {. filiformis, and } \\
P . \text { vulgaris }\end{array}$ & Bayuelo-Jimenez et al. 2002 \\
\hline \multirow[t]{3}{*}{ Cowpea } & \multicolumn{3}{|l|}{ Pest resistance } \\
\hline & $\begin{array}{l}\text { Cowpea mottle carmo } \\
\text { virus }\end{array}$ & V. vexillata & Ogundiwin et al. 2002 \\
\hline & Bruchid & $\begin{array}{l}\text { V. riukiuensis resistant to Callosobruchus maculates and } \\
\text { V. reflexo-pilosa to C. chinensis }\end{array}$ & Tomooka et al. 1992 \\
\hline \multirow[t]{5}{*}{ Lentil } & \multicolumn{3}{|l|}{ Disease resistance } \\
\hline & Ascochyta blight & Lens ervoides and L. odemensis & Ahmad et al. 1997 \\
\hline & Vascular wilt & L. nigricans subsp. ervoides and L. culinaris subsp. orientalis & Bayaa et al. 1995 \\
\hline & \multicolumn{3}{|l|}{ Agronomic characters } \\
\hline & Winter hardiness & L. culnaris subsp. orientalis & Hamdi et al. 1996. \\
\hline \multirow[t]{2}{*}{ Mungbean } & \multicolumn{3}{|l|}{ Pest resistance } \\
\hline & Bruchid & Vigna sublobata & Kaga and Ishimoto 1998 \\
\hline \multirow[t]{5}{*}{ Pea } & \multicolumn{3}{|c|}{ Pest and disease resistance } \\
\hline & Aschochyta blight & P. fulvum and $P$. humile & Ali et al. 1994a; Wroth 1998 \\
\hline & Weevil & P. fulvum & $\begin{array}{l}\text { Hardie and Clement 2001; } \\
\quad \text { Clement et al. } 2002\end{array}$ \\
\hline & \multicolumn{3}{|l|}{ Agronomic characters } \\
\hline & Cold tolerance & P. elstius (JI 2055) and P. elstius (JI 1398) & Ali et al. 1994b \\
\hline \multirow[t]{2}{*}{ Peanut } & \multicolumn{3}{|c|}{ Pest and disease resistance } \\
\hline & $\begin{array}{l}\text { Rust, leaf spots, nema- } \\
\text { todes, defoliators, } \\
\text { and virus }\end{array}$ & Several accessions from secondary and tertiary gene pool & $\begin{array}{l}\text { Holbrook and Stalker 2003; } \\
\text { Dwivedi et al. } 2003\end{array}$ \\
\hline
\end{tabular}


Table 6.12. (continued)

\begin{tabular}{|c|c|c|c|}
\hline Crop & Trait & Wild species & Reference \\
\hline \multirow[t]{2}{*}{ Rice bean } & Pest resistance & & \\
\hline & Bruchid & V. umbellata & Tomooka et al. 2000 \\
\hline \multirow[t]{11}{*}{ Soybean } & \multicolumn{3}{|c|}{ Pest and disease resistance } \\
\hline & $\begin{array}{l}\text { Sclerotinia stem rot } \\
\text { and sudden death } \\
\text { syndrome }\end{array}$ & G. tomentella & Hartman et al. 2000 \\
\hline & Rust & G. tomentella & Schoen et al. 1992 \\
\hline & $\begin{array}{l}\text { Soybean mosaic } \\
\text { virus (SMV) }\end{array}$ & G. canescens, G. clandestine, and G. tomentella & Zhuang et al. 1996 \\
\hline & Brown spot & $\begin{array}{l}\text { G. clandestina (PI 255745) and G. tabacina } \\
\text { (PI } 319697 \text { and PI 321392) }\end{array}$ & Lim and Hymowitz 1987 \\
\hline & Cyst nematode & $\begin{array}{l}\text { G. soja and G. gracilis } \\
\text { G. soja }\end{array}$ & $\begin{array}{l}\text { Lin } 1996 \\
\text { Wang et al. } 2001\end{array}$ \\
\hline & \multicolumn{3}{|l|}{ Agronomic characters } \\
\hline & $\begin{array}{l}\text { High linolenic fatty } \\
\text { acid }\end{array}$ & G. soja & Pantalone et al. 1997b \\
\hline & High protein content & G. soja and G. gracilis & Lin 1996 \\
\hline & Salinity tolerance & $\begin{array}{l}\text { G. argyrea (accession 1626), G. clandestina (accession1388 } \\
\text { and 1389), G. microphylla (accessions } 1143 \text { and 1195) }\end{array}$ & Pantalone et al. 1997a \\
\hline & $\begin{array}{l}\text { Herbicide }(2,4-D) \\
\quad \text { resistance }\end{array}$ & G. latifolia and G. microphylla & Hart et al. 1991 \\
\hline
\end{tabular}




\section{Pigeonpea Pest and disease resistance}

Pod fly and pod wasp $\quad$ C. scarabaeoides, $R$. bracteata, C. albicans, and F. stricta

Phytophthora blight

Sharma et al. 2003

Pod borer

C. platycarpus and C. serieus

C. acutifolius, C. albicans, C. platycarpus, C. reticulatus,

C. scarabaeoides, and C. serieus

Pod wasp

C. albicans and C. scarabaeoides

Pod fly and pod borer

C. scarabaeoides

Sterility mosaic virus (SMV)

Pod fly

Root-knot and reniform nematodes

Cyst nematode

Reniform and cyst nematodes

Agronomic characters

Salinity tolerance

\section{C. scarabaeoides, C. albicans, C. crassus, C. lineatus,} and $C$. sericeus

A. scarabaeoides, C. acutifolius, C. albicans, C. lineatus, C. scarabaeoides, and $C$. sericeus

C. scarabaeoides, $R$. reniformis, and C. reticulatus

C. scarabaeoides, R. densiflora, and Flamingia spp.

C. platycarpus

Rao et al. 2003

Rao et al. 2003

Rao et al. 2003

Verulkar et al. 1997;

Romeis et al. 1999

Kulkarni et al. 2003;

Rao et al. 2003

Saxena et al. 1990; Rao et al. 2003

Sharma et al. 1993b; Rao et al. 2003

Sharma et al. 1993a

Sharma 1995

Atylosia platycarpa, Rynchosia, Dunbaria, A. albicans, A. cajanifolia, C. platycarpus

Subbarao et al. 1991; Rao et al. 2003

Drought tolerance C. reticulates

Photoperiod

C. platycarpus and C. sericeus

Rao et al. 2003

Rao et al. 2003

High seed protein

Rao et al. 2003 
mold, and phytophthora rot in chickpea; to pod fly, pod wasp, and sterility mosaic virus in pigeonpea; and to Sclerotinia stem rot, sudden death syndrome, rust, soybean mosaic virus, and brown spot in soybean. Wild species are also reported to possess salinity tolerance in pigeonpea, soybean, and common bean; drought tolerance in pigeonpea, chickpea, and pea; cold tolerance in chickpea; herbicide tolerance in soybean; and winter hardiness in lentil and pea. Wild species have also been reported with high seed protein content in chickpea, pigeonpea, and soybean; high linoleic fatty acid in soybean; and photoperiod insensitivity in pigeonpea. For a detailed summary of peanut wild genetic resources possessing beneficial traits, the reader is referred to Dwivedi et al. (2003) and Holbrook and Stalker (2003). These examples convincingly demonstrate the potential of wild genetic resources to contribute agronomic traits that are suboptimum or entirely absent in cultivars (see section V A).

\section{IMPACT OF GENETIC RESOURCES IN CONVENTIONAL LEGUME BREEDING}

Plant breeding has contributed to increased crop productivity by systematically creating new high yielding and better adapted genotypes. Crop genetic resources have played an important role in providing novel genetic variation that legume breeders have used in improvement programs to develop these new genotypes. However, it is generally agreed that integrated approaches are necessary to continue to increase agricultural production and profitability by capturing the full benefit of plant biodiversity. The Global Plan of Action (FAO 1996) proposed a number of measures to foster greater utilization of genetic resources in crop improvement, including the expanded creation, characterization, and evaluation of core collections; increased genetic enhancement and base-broadening efforts; development and commercialization of underutilized species; development of new markets for local varieties and "diversity-rich" products and concomitant efficient seed production and distribution; comprehensive information systems for PGR; and promoting public awareness of the value of PGR for food and agriculture.

There are already many success stories related to the use of both elite and exotic gene pools of legume genetic resources in the development of improved genotypes that are better adapted to diverse environments, that possess resistance to abiotic and biotic stresses, and that are expected to increase legume production in target production systems across the globe. 


\section{A. Germplasm Distribution}

There are more than one million accessions of legume genetic resources documented in gene banks around the world, of which less than $20 \%$ $(187,418)$ are held by international agricultural research centers (IARCs), which, as a result, have been major sources of seed distribution to researchers in the developing and developed worlds (FAO 1998). Germplasm distribution from CIAT, CIMMYT, ICARDA, ICRISAT, ILRI, and IRRI was tracked during a period from 1973 to 2001 and over $80 \%$ of the one million samples distributed from these gene banks during this period were sent to organizations in developing countries (mostly to universities and national agricultural research institutes). Thus, much of the germplasm (73\%) that emerged from those countries through germplasm collections flowed back as distributed seed (Raymond 2001).

1. Chickpea. At ICRISAT, the pattern of germplasm distribution from 1973 to 1998 was analyzed; it was found that 112,818 samples of 16,311 chickpea accessions had been supplied to scientists in 81 countries, with countries in Asia receiving the maximum number of accessions followed by countries in the Americas, Europe, and Oceania. A maximum of 302 requests was received for a single accession, ICC 4973 (L 550), a kabuli cultivar from India. Shannon-Weaver diversity index $\left(\mathrm{H}^{\prime}\right)$ (Shannon and Weaver 1949) analysis of the accessions distributed was similar to the diversity in the entire collection. Chickpea germplasm distribution has resulted in the release of 15 varieties in 12 countries up until 1999 (Table 6.13).

2. Peanut. Up until 1998, ICRISAT distributed 14,180 accessions of peanut (94.7\% of the full collection), with only 794 accessions (5.3\%) having never been requested. Countries in Africa received the maximum number of accessions (92.3\%) followed by countries in Asia (76.6\%), Europe (5.6\%), the Americas (5.3\%), and Oceania (2.2\%). A maximum of 297 requests from 73 countries were received for the accession ICG 799 (Kadiri 3), a hypogaea cultivar from India. Most requests were received for accessions belonging to subsp. hypogaea followed by subsp. vulgaris, and subsp. fastigiata. The diversity index $\mathrm{H}^{\prime}$ of the accessions distributed was similar to the diversity of the entire collection, indicating that the diversity available in the entire collection has been well sampled by the users. Eleven varieties have been released in 12 countries from the peanut germplasm distributed from ICRISAT (Table 6.13).

3. Pigeonpea. ICRISAT distributed 65,747 seed samples of 10,648 pigeonpea accessions during the period 1974 to 2003, revealing that 
Table 6.13. List of chickpea, pigeonpea, peanut, broadbean, lentil, common bean, cowpea, and soybean genetic resources released as cultivars in different parts of the world.

\begin{tabular}{ll}
\hline Crop & Accession number and country of release \\
\hline Broadbean & BPL 710 (Icarus) in Australia; ILB 1270 (Giza Blanka) in Egypt; ILB \\
& 938(Giza 461) in Egypt; ILB 1269 (Barkat) in Iran. \\
Chickpea & ICC 237 in Oman; ICC 552 (Yezin1) in Myanmar; ICC 3274 \\
& (Barichhola 7) in Bangladesh; ICC 14880 (Hira) in Australia; ICC \\
& 4923 (Jyothi) in India; ICC 4951 in Myanmar; ICC 4998 (Bina Sola \\
& 2) in Bangladesh; ICC 6098 (Radha) in Nepal; ICC 8521 (Aztec) in \\
& USA; ICC 8649 (Shendi) in Sudan; ICC 11879 in Turkey, Algeria, \\
& Morocco, and Syria (Ghab 1); ICC 13816 in Algeria (Yialousa), \\
& Italy (Sultano), and Syria (Ghab 2); ICC 14559 (Barichhola 5) in \\
& Bangladesh; and ICC 14911 in Turkey and Morocco; ICC 4944 \\
& (Keyhman) in Myanmar.
\end{tabular}

Common bean

G76 in Cuba, Chile (as Redkloud) and Peru (Rojo Mollepata); G685 in Burundi, Kenya and Rwanda (Vunikingi); G858 in Rwanda (Muhondo 6), G1753 in Argentina; G2331 in Burundi (Muhondo) and Congo (Kihembe); G233 in Congo (Aliya), Kenya, Rwanda and Uganda (Umabano); G2579 in Panama (Renacimiento); G2816 in Burundi (Mavutaninka) and Ethiopia (Gofta); G2829 in Peru (Gloriabamba); G2858 in Congo (Maharagi Soja); G3410 in Peru and Rwanda (Puebla); G3645 in Peru (Jamapa); G3680 in Brazil (Ouro Negro), G3807 in Ecuador (Bayito); G4017 in Bolivia, Peru and Swaziland (Carioca); G4445 in Canada, China, Zimbabwe (Ex Rico) and Ethiopia (Awash/Bunsi); G4450 in Peru (Royal Red); G4494 in Burundi, Malawi, Mozambique , Panama (Calima) and Tanzania (Lyamungu 90); G4495 in Costa Rica (Porillo Sintético); G4523 in Panama (ICA Palmar), Peru (INIA 17), Rwanda (Rubona 5); G5476 in Tanzania (SUA90); G5773 in Bolivia, Costa Rica, Cuba, Mozambique, Peru (ICA Pijao), Guatemala (Suchitán) and Venezuela (Tenerife); G5853 in Peru (Cristál Blanco); G7930 in Peru (Alubia); G7951 in Bolivia (Araona) and Burundi; G11239 in Ethiopia (Mexican 142); G11780 (INIAP 416-Canario); and G12488 (ICA Llanogrande) in Colombia; G13369 and G13374 in Tanzania; G13614 in Rwanda (de Celaya); G13625 in Burundi; G14013 in Cuba (Guamá 23); G17702 in Bolivia (Carioca 80) (Voysest 2000).

Cowpea

IITA bred and shared a range of cowpea lines combining multiple resistances to diseases and pests, early maturity and preferred seed types to over 65 countries.

Lentil ILL 4400 in Algeria; ILL 481 (Indian head) in Canada; ILL 5523 (Centinela) in Chile; ILL 4605 (Precoz) in Egypt and Morocco and Pakistan (Manserha 89); ILL 358 and NEL 2704 in Ethipoia; ILL 5582 in Iraq, Jordan and Libya; ILL 4402 in Nepal; ILL 813 (Rubatab) in Sudan; ILL 942 (Erzurum 89), ILL 1384 (Malazgirt 89), and ILL 854 (Sazak 91) in Turkey; and ILL 784 (Crimson) in USA. 
Table 6.13. (continued)

\begin{tabular}{ll}
\hline Crop & Accession number and country of release \\
\hline Peanut & ICG 7886 (Cordi payne) in Jamaica; ICG 7827 in Phillipines, \\
& Myanmar (Sinpadetha 2), and Sierra Leone; ICG 2974 in Myanmar \\
& (Sinpadetha 3), Tanzania (Johari), and Gambia; ICG 273 (Sedi) in \\
& Ethiopia; ICG 221 in Swaziland; ICG 1697 (Singa) and ICG 1703 \\
& (Panter) in Indonesia; ICG 2271 in Nepal; ICG 7794 in Ethiopia; \\
& ICG 12991 in Uganda (Serenut 4T) and Malawi (Baka); ICG 7898 \\
& in Mauritius. \\
ICP 14770 (Abhaya) in India; ICP 14056 in Australia and Fiji (Royes); \\
ICP 8863 (Maruti) in India; ICP 11384 (Bageswari) in Nepal; ICP \\
9145 (Nandolo wa nswana) in Malawi; ICP 7035 (Kamica) in Fiji; \\
and ICP 6997 (Rampur Arhar) in Nepal. \\
TGX 306-036C and TGX 536-02D in Nigeria and Ghana; TGX 297- \\
192C and TGX 813-6D in Ghana; TGX 814-76D and TGX 849-294D \\
in D.R. Congo; TGX 849-313D, TGX 923-2E, TGX 1019-2EB, \\
TGX1019-2EN, and TGX1830-20E in Nigeria; TGX 1440-1E, TGX \\
1448-2E, and TGX 1740-2F in Nigeria, Togo and Benin; TGX 1485- \\
1D in Nigeria, Benin, Togo and Uganda. \\
\hline
\end{tabular}

$78.6 \%$ of the pigeonpea accessions stored in the gene bank have been accessed. The predominant users have been scientists in India followed by those in Kenya, Uganda, Malawi, Venezuela, and Australia. The germplasm accession ICP 7035 has been in greatest demand as it belongs to the vegetable type, possesses large seeds, and is resistant to sterility mosaic virus disease. Based on the ICRISAT-supplied pigeonpea germplasm, seven cultivars have been released in five countries (Table 6.13).

4. Broadbean and Lentil. ICARDA distributed 2,716 accessions of broadbean, 6,230 accessions of lentil, and 638 accessions of wild Lens species during 1990-94, most of them to developing countries. The greatest use of this material has been for identifying new sources of resistance to rust, Ascochyta blight, chocolate spot, and striga. Many broadbean-breeding programs in various countries were established using ICARDA germplasm resources. Thirteen lentil accessions and four broadbean accessions have been released in 14 and 3 countries, respectively (Robertson 1997; Robertson and Erskin 1997) (Table 6.13). 
5. Common Bean. CIAT distributed 80,000 Phaseolus bean germplasm samples during the period from 1979 to 1994. Fifty-five of the 203 common bean cultivars released in 37 countries are derived from genebank accessions that were included in CIAT international bean nurseries distributed worldwide during those years (Hidalgo and Beebe 1997; Voysest 2000) (see also Table 6.13).

\section{B. Impact of Domesticated Germplasm on Breeding Gains}

The distribution of grain legume genetic resources has had a profound impact particularly on the enhancement of biotic stress resistance and abiotic stress tolerance. For example, in common bean, CIAT and partners have used gene-bank accessions in the development of improved germplasm/cultivars with resistance to bean golden yellow mosaic virus, bean common mosaic necrosis virus, bean pod weevil, common bacterial blight, rust, web blight, as well as greater tolerance to high temperatures for Central America (Beebe et al. 1993, 1995; Beaver et al. 2003). In the case of cowpea, IITA and partners have developed unique germplasm with characteristics such as snap-type pods, green manure/cover crop capabilities, heat and chilling tolerance, delayed leaf senescence, differences in carbon isotope discrimination, harvest index, rooting and plant water- and nutrient-relations traits, resistance to root-knot nematodes, fusarium wilt, Striga, thrips, aphid, lygus bug, and cowpea weevil, and for quality traits including all-white and sweet grains. This has produced a valuable resource for all future breeding of cowpea cultivars for Africa and the USA (IITA 2001; Hall et al. 2003; Singh et al. 2003a). An improved Striga-resistant cowpea variety IT97K-499-38 yielded 50\% to $300 \%$ higher than the local varieties in Striga infested fields in Benin Republic that also caused high percentage of suicidal germination of Striga hermonthica seeds (IITA 2001). Early maturing chickpea germplasm (ICCV 2 and ICCV 96029) has enabled chickpea to escape damage due to drought, cold, and Helicoverpa at flowering and podding stages and thus opened up new possibilities for growing chickpea in semiarid and arid regions globally (Kumar and Abbo 2001).

IITA cowpea breeding lines combine multiple resistances to diseases and pests, early maturity and preferred seed types (Singh et al. 2003a). This material bred initially at IITA stations in Nigeria (Ibadan and Kano) was sent for testing worldwide and 65 countries released cultivars. In 2002, 409 sets of cowpea trials including 140 cultivars and breeding lines were shared by IITA with 105 partners in 24 countries (IITA 2002). In 2003, the farmer-to-farmer diffusion of an improved 
cowpea cultivar included more than 27,000 farmers in Kano State of Nigeria (IITA 2003).

IITA and African national programs are making concerted efforts to breed resistant soybean cultivars for home and industrial uses, which are driving intensive cultivation of soybean in several regions, particularly in Nigeria where about 80 soybean-based agro-processing businesses are flourishing (Singh et al. 2004). The resultant cultivars combine disease resistance with seed longevity, promiscuous nodulation, early maturity, and resistance to pod shattering. After thorough testing in mutilocation trials, many of these cultivars were released in Nigeria, Ghana, D.R. Congo, Benin, Togo, and Uganda.

\section{Use of Wild Germplasm}

There has been very limited use of exotic gene pools in legumes in comparison to the cereals or horticultural crops, in which the introduction of alien germplasm in breeding programs has been shown to have promise in widening the germplasm base of these crops (reviewed by Tanksley and McCouch 1997). The few successful examples of transfer of beneficial traits from wild legume accessions or species to legume breeding lines or cultivars include genes for resistance to rust, leaf spots, and nematodes in peanut (reviewed by Dwivedi et al. 2003; Holbrook and Stalker 2003); for cleistogamous flowers (Saxena et al. 1990a), high protein (Saxena et al. 1987), and cytoplasmic nuclear male sterility (Saxena and Kumar 2003) in pigeonpea; for resistance to cyst nematode and phytophthora root rot (Malhotra et al. 2002; Knights et al. 2003) as well as cold tolerance in chickpea (ICARDA 1996); and for arcelin-based bruchid resistance in common bean (Osborn et al. 1988; Acosta-Gallegos et al. 1998). The effectiveness of these novel traits has often been dramatic. For example, pigeonpea natural outcrossing species suffers from rapid genetic deterioration among germplasm accessions, genetic stocks, and cultivars but breeding has led to the development of a few elite partially cleistogamous lines with tenfold lower rates of outcrossing than the typical pigeonpea cultivars in India (Saxena et al. 1993). Similarly, cytoplasmic male sterility (CMS) lines originating from Cajanus scarabaeoides have opened up the possibility of producing the CMSbased hybrids in pigeonpea (Saxena and Kumar 2003).

Arcelins are abundant, lectin-like seed storage proteins that are present in wild $P$. vulgaris. Seven allelic variants of arcelin, designated as arcelin 1 to arcelin 7, have been reported (Osborn et al. 1986; Lioi and Bollini 1989; Santino et al. 1991; Acosta-Gallegos et al. 1998). High levels 
of resistance to the bean weevil in wild $P$. vulgaris populations of Mexican origin (Schoonhoven et al. 1983) are associated with the arcelin (arcelin 1 or arcelin 5) locus itself or a factor linked to it (Osborn et al. 1988; Goossens et al. 2000). Breeding lines derived from a cross between a wild accession (G02771) and cultivated $P$. vulgaris showed high levels of resistance to weevil (Kornegay et al. 1993).

The genes for promiscuous nodulation and seed longevity that led to the success of soybean cultivars in West Africa were introgressed from 'wild' sprawling soybean accessions (TGm 737, 719 618, 579, 577), mostly from Indonesia (Ortiz 2004b). Of course, the most difficult task for IITA soybean breeders was to recover the agronomic background of elite cultivars while maintaining the introgressed traits (E. Kueneman, FAO, pers. commun.).

\section{Conclusions from Conventional Manipulation of Genetic Resources}

There is a great abundance of useful genetic variability across the primary, secondary, and tertiary gene pools of most important legume crops. However, it is the elite breeding lines and landraces of the cultigen that breeders continue to focus on while the vast resources of the wild species remain largely untapped despite often containing the best sources of pest and disease resistance or tolerance to environmental stresses. The underlying reasons for the underutilization of crop related biodiversity are complex, varied, and often crop specific. Nevertheless, there are three main limiting factors that appear to be common to most crops: the lack of accurate and precise multilocational characterization of germplasm, the lack of rational systematic entry points into the vast international collections, and the lack of robust cost-effective tools to facilitate the efficient utilization of exotic germplasm in plant breeding programs. The development of core germplasm collections offers an important strategic solution to the first two constraints, even though there is some indication that current core and mini-core collections may be somewhat confounded by the type of phenotype data used in their assignments. Nevertheless, their existence has facilitated intensive phenotypic evaluation of diverse germplasm, which provides an essential foundation for future multidisciplinary efforts and refinements. This has already resulted in the identification of countless new sources of pest and disease resistance or tolerance to environmental stresses that had been overlooked by previous more extensive (but necessarily less intensive) screening processes. Clearly, the current challenge is to now define genetic mini-core collections that represent the total genetic diversity of gene banks that can equally serve current breeding criteria and as yet 
undetermined new breeding goals. This will then provide a highly valuable systematic entry point to germplasm collections for the entire research and breeding community. Meanwhile, rapid progress is being made in our knowledge and ability to manipulate these novel sources of economically important genetic variation. The opportunities offered in this respect by recent advances in legume genomics is the focus of the remaining sections of this paper.

\section{MOLECULAR-ENHANCED STRATEGIES FOR MANIPULATING NOVEL GENETIC VARIATION FOR LEGUME BREEDING}

\section{A. Interspecific Hybridization}

Inter-specific hybridization is an important method for expanding the gene pool available to grain legume breeders by introgressing genes from wild relatives of each crop (see Table 6.12 and also section III F). However, reproductive incompatibility mechanisms between species, embryo mortality, hybrid sterility, and limited genetic recombination present major barriers to greater use of wild germplasm from the secondary and tertiary gene pools (Muehlbauer et al. 1994). Reproductive isolation between a cultigen and its tertiary gene pool can be the result of crossing barriers both at the pre- and post-zygotic levels. Pre-zygotic barriers include biochemical incompatibilities that stop pollen germination, restrict pollen tube growth in the style or ovary, or prevent growth of the pollen tube towards the micropyle or embryo sac (Stalker 1980). Post-zygotic barriers include abnormal endosperm or embryo development, and chromosome elimination or aberration due to inconsistencies in parental genomes often resulting from ploidy level differences or cytoplasmic incompatibilities (Cooper and Brink 1940).

A list of the successful crosses made between grain legume cultigens and their wild species is provided in Table 6.14 along with an indication of the beneficial traits available from these inter-specific hybridization programs. Inter-specific crosses have been useful for incorporating resistance to nematodes in chickpea and groundnut; resistance to rust and leaf spots in groundnut; resistance to bruchid in mung bean and cowpea; resistance to ascochyta blight in pea; resistance to common bacterial blight in common bean; tolerance to drought and cold temperature in chickpea; tolerance to salinity in pigeonpea; and improved agronomic traits and seed quality in soybean, chickpea, and pigeonpea. Inter-specific hybridization in pigeonpea has generated progeny with unique characteristics such as dwarf stature, new types of cytoplasmic 
Table 6.14. Examples of successful gene introgression from wild species to cultivated grain legume crops.

\begin{tabular}{|c|c|c|}
\hline Crop & $\begin{array}{l}\text { Source of } \\
\text { introgressed trait }\end{array}$ & Description of interspecific derivatives \\
\hline \multicolumn{3}{|c|}{ Successful trait introgression from wild species to the cultigen } \\
\hline Chickpea & $\begin{array}{l}\text { C. reticulatum and } \\
\text { C. echinospermum }\end{array}$ & $\begin{array}{l}\text { Resistance to cyst nematode, drought and cold tolerance, } \\
\text { high biomass, and earliness. }\end{array}$ \\
\hline Common Bean & P. acutifolius & $\begin{array}{l}\text { Introgression of common bacterial blight resistance into } \\
\text { common bean. }\end{array}$ \\
\hline \multirow[t]{2}{*}{ Mungbean } & V. sublobata & $\begin{array}{l}\text { Bruchid resistance incorporated into cultivated mungbean } \\
\text { (V. radiata). }\end{array}$ \\
\hline & V. glabrescens & Pest resistance incorporated into $V$. radiata. \\
\hline Pea & P. fulvum (JI1006) & Ascochyta blight resistance incorporated. \\
\hline Peanut & Several species & $\begin{array}{l}\text { Resistance to rust, leaf spots, nematodes, insect pests, } \\
\text { and peanut bud necrosis virus disease. }\end{array}$ \\
\hline \multirow[t]{2}{*}{ Soybean } & G. soja & $\begin{array}{l}\text { Introgressed lines carrying the PI407305 haplotype } \\
\text { at QTL locus demonstrated 9.4\% yield advantage } \\
\text { over control genotypes. }\end{array}$ \\
\hline & G. soja and G. gracilis & $\begin{array}{l}\text { Selected introgressed lines showed profuse pod } \\
\text { production and branching, large seeds and strong } \\
\text { stems, high protein and fat content. }\end{array}$ \\
\hline
\end{tabular}

Malhotra et al. 2003; Singh and Ocampo 1997

Rava et al. 1996

Kaga and Ishimoto 1998

Chen et al. 1989

Wroth 1998

Dwivedi et al 2003; Hoolbrook and Stalker 2003

Concibido et al. 2003; Wang et al. 2004

Lin 1996 


\section{Viable hybrids produced from crosses between wild species and cultivated crops}

\begin{tabular}{|c|c|c|c|}
\hline Cowpea & V. vexillata & $\begin{array}{l}\mathrm{F}_{1} \text { hybrid produced between } V \text {. vexillata } \times V \text {. unguiculata } \\
\text { using in vitro embryo rescue procedure. }\end{array}$ & $\begin{array}{l}\text { Gomathinayagam et al. 1998; } \\
\text { Ogundiwin et al. } 2002\end{array}$ \\
\hline Lentil & $\begin{array}{l}\text { L. orientalis, } \\
\text { L. odemensis, } \\
\text { L. ervoides, and } \\
\text { L. nigricans }\end{array}$ & $\begin{array}{l}\text { Viable hybrids produced between } L \text {. culinaris and the } \\
\text { four wild species. }\end{array}$ & Ahmad et al. 1995 \\
\hline \multirow[t]{4}{*}{ Pigeonpea } & C. platycarpus & $\begin{array}{l}\text { Using the embryo rescue technique, } \mathrm{F}_{1} \text { hybrids were } \\
\text { produced but these were completely pollen sterile. }\end{array}$ & Mallikarjuna and Moss 1995 \\
\hline & $\begin{array}{l}\text { C. reticulatus var. } \\
\text { grandifolius }\end{array}$ & $\mathrm{F}_{1}$ hybrids between $C$. cajan and $C$. reticulatus produced. & Reddy et al. 2001 \\
\hline & C. acutifolius & $\mathrm{F}_{1}$ and $\mathrm{BC}_{1}$ hybrids produced. & Mallikarjuna and Saxena 2002 \\
\hline & A. albicans & $\begin{array}{l}\text { Genetic introgression of salinity tolerance from } \\
\text { A. albicans to } C \text {. cajan demonstrated in the } \mathrm{F}_{1} \text {. }\end{array}$ & Subbarao et al. 1990 \\
\hline Soybean & G. tomentella & $\begin{array}{l}\text { Fertile plants produced from backcross introgression into } \\
\text { G. max from tertiary gene pool species G. tomentella. }\end{array}$ & Singh et al. 1993 \\
\hline
\end{tabular}


male sterility, and cleistogamous flowers (Reddy 1990). Products of inter-specific hybridization are not usually released directly as varieties due to deleterious linkage drag usually associated with introgression of traits from wild species. However, 'Coan' and Nema TAM in peanut (Simpson and Starr 2001; Simpson et al. 2003) and Tara and Jules in common bean (Muñoz et al. 2004) are notable exceptions, where deleterious linkage drag to a large extent has been overcome. They have been released in the United States. In general, inter-specific derivatives are treated as pre-breeding products that are useful for introducing new sources of variation into the initial cycles of a breeding program.

The most useful tertiary gene pool species for common bean breeders has been $P$. acutifolius or tepary bean, which offers many sources of resistance to diseases and pests and tolerance to environmental stresses (Pratt and Gordon 1994; Mejía-Jiménez et al. 1994). Congruity backcrossing has been shown to help in the transfer of desirable quantitative traits between the two species by raising recombination, although total rates of introgression still remain low (Mejía-Jiménez et al. 1994; Muñoz et al. 2004). Attempts to incorporate useful genes of rice bean ( $V$. umbellata) into adzuki bean ( $V$. angularis) have been even more difficult due to reproductive barriers between the two cultigens. However, another wild relative of adzuki bean, V. riukiuensis, is cross compatible with both adzuki and rice beans and therefore may serve as a bridging species (Siriwardhane et al. 1991). In the case of broadbean, no wild progenitors are known and there are no reported cases of interspecific hybridization between cultivated broadbean and any of the wild Vicia species.

\section{B. Linkage Mapping and QTL Detection}

1. Molecular Markers and Genetic Linkage Maps. High-density genetic linkage maps are a useful basis for identifying markers tightly linked to quantitative trait loci (QTL) that contribute to economically important traits (Paterson et al. 1988; Lander and Botstein 1989), for cloning gene(s) by chromosome walking (Wicking and Williamson 1991), and for developing marker-assisted selection of desirable genes in breeding programs (Burr et al. 1983; Tanksley et al. 1989). A wide range of marker techniques have been used for linkage mapping and QTL detection in legumes, including those based on morphological and biochemical (isozymes and proteins) assays, hybridization assays such as RFLP (restriction fragment length polymorphism), and polymerase chain reaction (PCR)-based assays such as RAPD (random amplified polymorphic 
DNA), AFLP (amplified fragment length polymorphism), and SSR (simple sequence repeats) or microsatellites.

The high polymorphism, high reproducibility, easy automation, and codominant nature of microsatellite markers have led to them becoming the assay of choice for marker-assisted selection. The AFLP marker system remains the most powerful and cost-effective assay for background selection in marker-accelerated backcross programs. In many crop plants, including some of the legumes, expressed sequence tags (ESTs) from tissue specific cDNA libraries are being increasingly used as candidate gene markers. However, EST markers generally detect a low level of polymorphism in intra-specific mapping populations and thus need to be converted to CAPS (cleaved amplified polymorphic sequences) (Caranta et al. 1999) or SNP (single nucleotide polymorphism) markers before routine use in mapping and molecular breeding.

Large-scale SNP marker development in legumes has been inspired by the large-scale EST sequencing and development of high-density genetic linkage maps in humans (1.42 million markers) (The International SNP Map Working Group 2001) and in model systems such as rice (Oryza sativa) (Nasu et al. 2002) and Arabidopsis thaliana (Cho et al. 1999; Drenkard et al. 2000; Jander et al. 2002; Schmid et al. 2003; Torjek et al. 2003). SNP development has also been initiated in the model legumes, $M$. truncatula and $L$. japonicus (Table 6.15). SNP markers offer several key advantages over conventional genetic markers; they are biallelic, codominant, highly abundant, capable of high throughput genotyping, have low mutation rates, and are often linked to genes (Kwok and Gu 1999).

Soybean is the most advanced legume crop with regard to marker technologies, already having a large set of SNP markers, while most other legume crops have only progressed to routine application of SSRs and/or ESTs with a few proof-of-concept SNP markers in chickpea, common bean, cowpea, peanut, mung bean, pea, and pigeonpea (Table 6.15). Thus, there is an urgent need to accelerate marker development in most of the legumes, particularly the research-neglected species.

Genetic linkage maps are available for both model and crop legumes with linkage groups aligned to the haploid chromosome complement of the two species (Table 6.16). These maps have an average marker density of $4.24 \mathrm{cM}$ for M. truncatula, and 0.6 to $2.6 \mathrm{cM}$ for L. japonicus. Genetic linkage maps for the legume crops are generally much less saturated and have been derived from both (i) inter-specific populations as in chickpea and lentil (Table 6.17) or mung bean, cowpea, adzuki bean, and peanut (Table 6.18) and (ii) intra-specific populations as in pea, chickpea, broadbean, and grasspea (Table 6.19), or soybean, common bean, and cowpea (Table 6.20). Most of the initial genetic maps reported 
Table 6.15. Overview of SSR, EST, SNP, and CAP markers reported in model species and grain legume crops.

Marker Summary of the marker information Reference

\section{Crop Legumes}

Broadbean

SSR

12 SSR located on chromosome 1.

Pozarkova et al. 2002

\section{Chickpea}

SSR

10 SSR from genomic library of C. arietinum cultivar Pusa 362.

218 SSR primers designed from 389 microsatellite containing clones.

43 of the 53 clones from chickpea genomic libraries selected for sequencing showed the presence of microsatellites.

EST 2,860 EST sequences from subtracted root library.

Sethy et al. 2003

Winter et al. 1999

Huttel et al. 1999

Winter et al. 1999

ICRISAT 2002

Common

bean SSR

57 SSR from coding and non-coding sequences.

Isolated 21 SSR (GA)n from a highly microsatellite-enriched library.

Isolated, cloned, and sequenced genomic DNA fragments containing 68 microsatellite loci from 3 Phaseolus vulgaris genomic libraries, and number of alleles ranged from 1-14

alleles per locus when tested on 21 diverse genotypes.

49 SSRs from common bean and 12 from the genus Vigna.

Forty-four primer pairs derived from cowpea microsatellite-enriched libraries constructed from the DNA of the breeding line IT84S-2264-2; one primer pair each derived from the sequences of the 1-amino-cycloprane-1-carboxylate oxidase cDNA of mungbean and the protein kinase cDNA of mothbean.

EST 728 EST sequences submitted to dbEST.

SNP SNPs detected between the homologous sequences of the 1150-bp DNA fragments on COK-4 locus from anthracnose resistant (SEL 1308) and susceptible (Black Magic) genotypes.

\section{Cowpea}

SSR

Forty-four SSR isolated from cowpea microsatellite-enriched libraries constructed from the DNA of a breeding line IT84S-2264-2, and one SSR each from sequences of the 1-aminocycloprane-1-carboxylate oxidase cDNA of mungbean ( $V$. radiata) and the protein kinase cDNA of mothbean ( $V$. aconitifolia).

Blair et al. 2003

Yaish and Vega 2003

Gaitan-Solis et al. 2002

Yu et al. 1999

Li et al. 2001

Hernandez et al. 2004 Melotto and Kelly 2001

Li et al. 2001 


\section{Mungbean}

SSR

Pea

SSR

(1)

23 microsatellite loci and six cryptically simple sequence repeats.

171 SSR from 663 sequences retrieved from genebank/EMBL databases: CT/AG and

TCT/AGA most frequent nucleotides.

318 SSR (http://www.agrogene.com/ssrdevelopment.htm).

$$
15 \text { SSR }
$$

Peanut

SSR

110 SSR from genomic cDNA libraries of peanut cultivar, Florunner.

Six SSR.

SNP Several SNP detected while comparing the coding sequences from the high and low oleic acid genotypes: two (at 442 and $448 \mathrm{bp}$ ) associated with the high O/L oil trait.

\section{Pigeonpea}

SSR

20 SSR.

Soybean

SSR

EST

SNP

\section{SSR}

120,000 EST from more than 50 cDNA libraries, coalesced into 16,928 contigs and 17,336 singletons. On average, each contig composed of 6 ESTs and spanned $788 \mathrm{bp}$.

308,582 EST

29,540 EST obtained by sequencing a cDNA library constructed from salicylic acid treated soybean seedlings.

216 SNP detected from 116 gene-derived STSs.

Eight SNP detected from six-converted AFLP markers representing 996 bp sequences from alleles of each of Forrest (resistant to soybean cyst nematode) and Essex (susceptible to cyst nematode).

Two SNPs (A519-1SNPs) reported within approximately 400 bp of the sequence of RFLP locus A519-1.

\section{Scarlet runner bean}

Kumar et al. 2002

Burstin et al. 2001

Ford et al. 2002

Ferguson et al. 2004

Hopkins et al. 1999

Lopez et al. 2000

Burns et al. 2001

Cregan et al. 1999a

Shoemaker et al. 2002

Rudd 2003

Tian et al. 2004

Zhu et al. 2003a

Meksem et al. 2001b

Coryell et al. 1999

Rudd 2003 
Table 6.15. (continued)

Marker Summary of the marker information Reference

\section{Model legumes}

\section{Medicago truncatula}

SSR $\quad$ Five SSRs obtained from microsatellite-enriched genome libraries and four from sequences available in GenBank.

EST 899 ESTs, of which 603 have homology to known genes, from root-hair-enriched cDNA library (http://bio-SRL8.stanford.edu).

EST 10,500 EST markers from 28,000 cDNAs obtained from 5- to 13-day old immature seeds. $40 \%$ of these ESTs have no match in the public sequence databases suggesting that many represent mRNAs derived from genes specifically expressed in seeds (www.plantphysiol.org).

EST Over 140,000 ESTs sequences from $30 \mathrm{cDNA}$ libraries representing various vegetative and reproductive organs. Of these, 340 putative gene products or tentative consensus sequences expressed solely in root nodules, and are represented by two to 379 ESTs (http://www.tigr.org/tdb/mtgi).

EST ESTs to characterize the sets of genes expressed in roots during Rhizobial and/or mycorrhizal symbiosis: 21,473 5'-and 3'-ESTs grouped into 6359 clusters, corresponding to distinct virtual genes, along with 52,498 other $M$. truncatula ESTs available in the dbEST database.

\section{Lotus japonicus}

EST $\quad 110$ ESTs

EST $93,0005^{\prime}$ and $3^{\prime}$ ESTs obtained from normalized and size-selected cDNA libraries constructed from seven different organs, and 70,137 of these 3' ESTs clustered into 20,127 nonredundant groups (http://www.kazusa.or.jp/en/plant/lotus/est/).

Covitz et al. 1998

White et al. 2000

Fedorova et al. 2002

Journet et al. 2002

http://www.medicago.org

Szczyglowski et al. 1997

Asamizu et al. 2000

Poulsen and Podenphant 2002 
Table 6.16. Overview of genetic and cytogenetic linkage maps generated for Lotus japonicus and Medicago truncatula.

Marker and mapping population details

Description of the genetic, cytogenetic or chromosomal map

Reference

\section{Medicago truncatula}

313 markers (72 RAPD + 220 AFLP +

19 known genes +2 isozymes)

124 RILs from Jemalong 6 × DZA315.16

\section{Lotus japonicus}

15 markers (3 morphological + 12 DAF) $100 \mathrm{~F}_{2}$ plants from B-129-S9 Gifu $\times$ B-581 Funakura

605 markers (524 AFLP + 3 RAPD + 39 gene-specific +33 SSRs + 6 recessive symbiotic mutant loci) $\mathrm{F}_{2}$ populations from $L$. japonicus $\times$ L. filicaulis

$\mathrm{F}_{2}$ population from L. japonicus Gifu $\times$ L. filicaulis

217 markers (single-dose RFLP, RAPD, ISSR, STS, isozyme, and 5 duplex RFLP) Tetraploid Lotus corniculatus population
289 uniformly distributed markers mapped on 8 linkage groups with a total map length of $1225 \mathrm{cM}$, and average map density of $4.24 \mathrm{cM}$.

Eight $M$. truncatula LG are homologous to those of diploid alfalfa (M. sativa) implying a good level of macrosynteny between the two genomes.

Molecular cytogenetic map constructed based on a pachytene DAPI

karyogram that enabled the identification of all chromosomes based on chromosome length, centromere position, heterochromatin patterns and position of three repetitive sequences.

This was the first molecular linkage map of this model legume with 11 linkage groups.

Genetic map consisting of 6 linkage groups corresponding to the 6 chromosomes in L. japonicus. The total map length is $367 \mathrm{cM}$ and the average marker distance is $0.6 \mathrm{cM}$.

Chromosomal map developed using DNA clones from 32 genomic regions that enabled the assignment of linkage groups to chromosomes, the comparison between genetic and physical distances throughout the genome, and partially characterized different repetitive sequences.

Nineteen of these clones were also mapped genetically; that makes the $L$. japonicus map one of the most extensive correlations of the genetic and chromosomal maps in plants, enabling the determination of physical and genetic distance regions along the whole chromosome complement.

The map spans $572.1 \mathrm{cM}$ comprising 6 linkage groups: three (LG 2, 3, and 4) well defined; two (LG 5 and 6) poorly discriminated due to apparent marker duplication between them, and one (LG 1) was poorly defined because of high degree of differentiation between its homologous members.
Thoquet et al. 2002

Kulikova et al. 2001

Jiang and Gresshoff 1997

Sandal et al. 2002

Pedrosa et al. 2002

Fjellstrom et al. 2003 
Table 6.17. Overview of genetic linkage maps generated from interspecific crosses in temperate grain legume crops.

\section{Chickpea $(\mathrm{n}=\mathbf{8})$}

47 gene specific markers integrated into an existing map based on SSR, AFLP, DAF, and other anonymous markers (Winter et al. 1999, 2000) 159 RILs from ICC $4958 \times$ PI 489777

51 markers (one RGA and 50 STMS) 142 RILs from FLIP 84-92C $\times$ PI 599072

354 markers (118 STMS, 96 DAF, 70 AFLP, 37 ISSR, 17 RAPD, 8 isozyme, 3 cDNA, 2 SCAR) 130 RILs from ICC4958 × PI489777

120 SSR markers 90 RILs from ICC $4958 \times$ PI 489777)

91 markers (9 morphological +27 isozyme +10 RFLP + 45 RAPD) $3 \mathrm{~F}_{2}$ populations

144 markers (1 morphological + 11 isozyme +111 RAPD + 21 ISSR) 142 RILs from FLIP84-92C $\times$ PI 599072

\section{Lentil ( $(n=7)$}

200 markers (71 RAPDs, 39 ISSRs, 83 AFLPs, 2 SSRs, and 5 morphological) $113 \mathrm{~F}_{2}$ plants from $L$. culinaris ssp. culinaris $\times$ L. culinaris ssp orientalis

177 markers (89 RAPD + 79 AFLP + 6 RFLP + 3 morphological) 86 RILs from ILL $5588 \times$ L692-16-1 (s)
The map consists of 296 markers and covers $2483.3 \mathrm{cM}$ in 8 large and 4 small linkage groups. The gene-specific markers derived from sequences of protein known to be involved in plant defense responses are distributed throughout the whole map but particularly on linkage groups $3-5$.

The map consists of 167 markers and covers $1174.5 \mathrm{cM}$ with 9 linkage groups, with an average marker distance of $7.0 \mathrm{cM}$.

303 markers cover $2077.9 \mathrm{cM}$ in 8 large and 8 small linkage groups with an average distance of $6.8 \mathrm{cM}$ between markers. A clustering of markers observed in central regions of linkage groups. The map includes 3 loci contributing to Fusarium resistance.

120 markers grouped into 11 linkage groups with a total map length of $613 \mathrm{cM}$ and an average distance of $5.47 \mathrm{cM}$ between markers.

The map consists of 10 linkage groups with a total distance of 550 $\mathrm{cM}$, and average marker density of $6.04 \mathrm{cM}$.

The 116 markers grouped into 9 linkage groups with a total map length of $981.6 \mathrm{cM}$ and average marker density of $8.4 \mathrm{cM}$.

At a LOD score of 3, 161 markers were grouped into 10 linkage groups covering 2,172.4 cM, with an average distance between markers of $15.87 \mathrm{cM}$. There were six linkages with 12 or more markers each, and four small groups with two or three markers each.

The map comprises of 177 markers grouped into 7 linkage groups with a total map distance of $1073 \mathrm{cM}$ and average marker density of $6.0 \mathrm{cM}$.
Pfaff and Kahl 2003

Tekeoglu et al. 2002

Winter et al. 2000

Winter et al. 1999

Simon and Muehlbauer 1997

Santra et al. 2000

Duran et al. 2004

Eujayl et al. 1998a 
Table 6.18. Overview of genetic linkage maps generated from interspecific crosses in tropical grain legume crops.

\begin{tabular}{|c|c|c|}
\hline Marker and population size & Summary of the genetic linkage map & Reference \\
\hline \multicolumn{3}{|l|}{ Adzuki bean $(n=11)$} \\
\hline $\begin{array}{l}132 \text { markers (108 RAPD }+19 \text { RFLP }+5 \\
\text { morphological) } \mathrm{F}_{2} \text { population from Adzuki bean } \\
\text { and its wild relative } V . \text { nakashimae }\end{array}$ & $\begin{array}{l}\text { The map consists of } 14 \text { linkage groups and covers a distance of } \\
1250 \mathrm{cM} \text {, with an average between marker density of } 9.47 \\
\text { cM. }\end{array}$ & Kaga et al. 1996 \\
\hline \multicolumn{3}{|l|}{ Cowpea $(n=11)$} \\
\hline $\begin{array}{l}171 \text { markers (RAPD, SSR, AFLP, and } \\
\text { morphological) RIL population from improved } \\
\text { cowpea cultivar } \times \text { wild relative }\end{array}$ & $\begin{array}{l}\text { The map consists of } 12 \text { linkage groups with a total map length } \\
\text { of } 2269 \mathrm{cM} \text { and average marker density of } 13.27 \mathrm{cM} \text {. }\end{array}$ & Ortiz 2003 \\
\hline $\begin{array}{l}80 \text { markers (77 RAPD }+3 \text { morphological) RIL } \\
\text { population from IT84S-2246- } 4 \times \text { TVNu 110-3A }\end{array}$ & $\begin{array}{l}\text { The map spanned } 669.8 \mathrm{cM} \text {, and } 12 \text { linkage groups that ranged } \\
\text { in size from } 14.0 \text { to } 175.4 \mathrm{cM} \text {. The distribution of interval } \\
\text { sizes between adjacent markers ranged from } 0.7 \text { to } 26.7 \mathrm{cM} \\
\text { with an average distance of } 9.9 \mathrm{cM} \text {. }\end{array}$ & Ubi et al. 2000 \\
\hline \multicolumn{3}{|l|}{ Mungbean $(n=11)$} \\
\hline 255 RFLP loci 80 RILs from Berken $\times$ ACC 41 & $\begin{array}{l}\text { The map consists of } 13 \text { linkage groups with a total distance of } \\
737.9 \mathrm{cM} \text { and average marker density of } 3.0 \mathrm{cM} \text {. The linkage } \\
\text { groups vary in length from } 8.7 \mathrm{cM} \text { to } 100.7 \mathrm{cM} \text {. }\end{array}$ & $\begin{array}{l}\text { Humphry et al. } \\
2002\end{array}$ \\
\hline \multicolumn{3}{|l|}{ Peanut $(n=20)$} \\
\hline RFLP markers $\mathrm{BC}_{1}$ from TxAG $6 \times$ Florunner & $\begin{array}{l}370 \text { RFLP loci mapped into } 23 \text { linkage groups with a total map } \\
\text { length of } 2210 \mathrm{cM} \text { and average marker density of } 5.97 \mathrm{cM} \text {. }\end{array}$ & Burow et al. 2001 \\
\hline
\end{tabular}


Table 6.19. Overview of genetic linkage maps generated from intra-specific crosses in temperate grain legume crop genotypes.

\begin{tabular}{|c|c|c|}
\hline Marker and population size & Summary of the genetic linkage map & Reference \\
\hline \multicolumn{3}{|l|}{ Broadbean $(n=6)$} \\
\hline $\begin{array}{l}84 \text { markers ( } 3 \text { enzyme }+76 \text { RAPD }+2 \text { seed protein } \\
\text { genes }+3 \text { SSRs) } 196 \mathrm{~F}_{2} \text { plants from } \mathrm{Vf} 6 \times \mathrm{Vf} 136\end{array}$ & $\begin{array}{l}\text { The map consists of } 16 \text { linkage groups covering } 1445.5 \mathrm{cM} \text {, with an } \\
\text { average marker density of } 13.77 \mathrm{cM} \text {. }\end{array}$ & $\begin{array}{l}\text { Roman et al. } \\
2002\end{array}$ \\
\hline $\begin{array}{l}71 \text { markers ( } 9 \text { isozyme }+45 \mathrm{RAPD}+5 \text { seed protein } \\
\text { genes }+12 \mathrm{SSR}) 11 \mathrm{~F}_{2} \text { populations sharing Vf6 as } \\
\text { female parent }\end{array}$ & $\begin{array}{l}192 \text { loci arranged into } 14 \text { linkage groups with a total map distance } \\
\text { of } 1559 \mathrm{cM} \text {, and average marker density of } 8 \mathrm{cM} \text {. }\end{array}$ & $\begin{array}{l}\text { Roman et al. } \\
2004\end{array}$ \\
\hline \multicolumn{3}{|l|}{ Chickpea $(\mathrm{n}=8)$} \\
\hline $\begin{array}{l}66 \text { markers (51 STMS + } 3 \text { ISSR + } 12 \text { RGA) } 85 \mathrm{~F}_{2} \\
\text { plants from ICC12004 } \times \text { Lasseter }\end{array}$ & $\begin{array}{l}\text { The map consists of } 8 \text { linkage groups with a total map length of } \\
534.5 \text { cM and average distance between markers of } 8.1 \text { cM. LG I } \\
\text { represents the largest and LG VIII the smallest linkage group. } \\
\text { SSR markers are distributed throughout genome while RGA } \\
\text { markers cluster along with ISSR makers on LGs 1, 2, and } 3 \text {. }\end{array}$ & $\begin{array}{l}\text { Flandez- } \\
\text { Galvez et al. } \\
2003\end{array}$ \\
\hline \multicolumn{3}{|l|}{ Grasspea $(n=7)$} \\
\hline $\begin{array}{c}75 \text { markers (71 RAPD + } 3 \text { isozyme }+1 \\
\text { morphological) } 100 \mathrm{~F}_{2} \text { individuals }\end{array}$ & $\begin{array}{l}\text { Sixty-nine markers (one morphological }+3 \text { isozyme }+65 \text { RAPD) } \\
\text { assigned to } 14 \text { linkage groups with a total map length of } 898 \mathrm{cM} \\
\text { and average distance between markers was } 17.2 \mathrm{cM} \text {. }\end{array}$ & $\begin{array}{l}\text { Chowdhury } \\
\text { and Slink- } \\
\text { ard } 1999\end{array}$ \\
\hline $\begin{array}{l}64 \text { markers ( } 47 \text { RAPD }+7 \text { STMS }+13 \text { STS/CAPS) } \\
92 \text { backcross derived individuals from ATC } \\
80878 \times \text { ATC } 80407\end{array}$ & $\begin{array}{l}\text { Sixty-four markers assigned to } 9 \text { linkage groups with a total map } \\
\text { length of } 803.1 \mathrm{cM} \text {, and the average spacing between markers } \\
\text { was } 15.8 \mathrm{cM} \text {. }\end{array}$ & $\begin{array}{l}\text { Skiba et al. } \\
2004\end{array}$ \\
\hline
\end{tabular}


Pea $(n=7)$

69 markers (3 morphological + 4 RGA + 56 RFLP + $4 \mathrm{SSR}+2 \mathrm{RAPD}) 174 \mathrm{~F}_{2}$ plants from Erygel $\times 661$

240 markers (164 AFLP + 33 RAPD + 12 ISSR + 5 CAPs + 1 STS + 11 isozymes + 14 morphological) 104 RILs from Wt $10245 \times$ Wt 11238

206 markers (192 AFLP + 13 RAPD + 1 STS) 88 RILs from Carneval $\times$ MP 1401

209 markers (RFLP/RAPD/AFLP/ RGA) $102 \mathrm{~F}_{2}$ plants from Prima $\times$ OSU442-15

240 RAPD markers 139 RILs from Terese $\times$ K 586

355 RFLP markers 71 RILs from JI $281 \times$ JI 399
69 markers mapped across 12 linkage groups with a total map distance of $550 \mathrm{cM}$, and average distance between markers of about $8.0 \mathrm{cM}$.

204 markers mapped across 9 linkage groups spanning a total of $2416 \mathrm{cM}$, with an average distance between markers of $12 \mathrm{cM}$. The size of the linkage groups ranged from $34 \mathrm{cM}$ to $503 \mathrm{cM}$ but around half of the map intervals are shorter than $10 \mathrm{cM}$ and only $1.5 \%$ intervals longer than $30 \mathrm{cM}$.

206 markers assigned to 10 linkage groups spanning a total of 1274 cM of pea genome, with an average distance between markers of $6.2 \mathrm{cM}$. Fourteen markers were common to the previous pea genetic maps (Gilpin et al. 1997; Laucou et al. 1998) that allowed six (I, II, III, IV, VI, and VII) of these linkage groups to be aligned to the previous pea linkage maps, whereas four linkage groups (A to D) remained unassigned.

The map consists of 14 linkage groups and covers $1330 \mathrm{cM}$ distance, with an average distance between markers of $6.36 \mathrm{cM}$.

The map consists of 9 linkage groups and covers 1139 cM distance, with an average marker density of $4.75 \mathrm{cM}$. The size of the $9 \mathrm{LGs}$ ranges from $21.1 \mathrm{cM}$ to $187.1 \mathrm{cM}$.

The map consists of 7 linkage groups covering $1881 \mathrm{cM}$, with an average distance between markers of $5.29 \mathrm{cM}$.
Dirlewanger et al. 1994

Irzykowska et al. 2001

Tar'an et al. 2003b

Gilpin et al. 1997

Laucou et al. 1998

Ellis et al. 1992 
Table 6.20. Overview of genetic linkage maps generated from intra-specific crosses in tropical grain legume crop genotypes.

\section{Common bean $(\mathrm{n}=11)$}

246 markers (78 SSR, 48 RFLP, 102 RAPD and 18 AFLP) on 87 RILs (DOR364 $\times$ G 19833) as well as 22 microsatellites on 75 additional RILs from BAT93 $\times$ Jalo EEP558

563 markers (120 RFLP + 430 RAPD + few isozyme/ morphological) 75 RILs from BAT93 $\times$ Jalo EEP558

152 markers (112 RFLP, 7 isozyme, 8 RAPD, 15 known genes) $\mathrm{F}_{2}$ population from BAT93 $\times$ Jalo EEP558

244 markers (224 RFLP + 9 each isozyme and seed protein +2 morphological) Back cross population from XR-235-1-1 $\times$ Calima

\section{Cowpea $(\mathrm{n}=11)$}

181 markers (133 RAPD + 19 RFLP + 25 AFLP + 3 morphological and classical +1 biochemical) 94 RILs from IT84S-2049 × 524B

423 markers (242 AFLP + 181 previously mapped RAPD, RFLP, AFLP, and biochemical) 94 RILs from IT84S-2049 $\times 524 \mathrm{~B}$
A genome-wide anchored map consists of 246 markers covering 11 linkage groups with a total map length of $1720 \mathrm{cM}$ and average SSR marker density of $19.5 \mathrm{cM}$.

SSR loci were distributed across each of the 11 chromosomes, with the number per chromosome ranging from 5 to 17 with an average of 10 SSRs.

The map consists of 11 linkage groups with a total map length of $1226 \mathrm{cM}$ and average marker density of $2.17 \mathrm{cM}$.

Total map length of $827 \mathrm{cM}$ in 15 linkage groups. Average interval between markers of $6.5 \mathrm{cM}$.

The 244 markers assigned to 145 loci/locus across 11 linkage groups with a total map length of $960 \mathrm{cM}$, and average marker density of $3.93 \mathrm{cM}$.

The 181 loci grouped into 12 linkage groups spanning $972 \mathrm{cM}$ with an average marker distance of $6.4 \mathrm{cM}$. Linkage groups ranged from 3 to $257 \mathrm{cM}$ in length and included 2 to 41 markers.

The genetic map consists of 11 linkage groups with a total map length of $2670 \mathrm{cM}$ and average marker density of $6.43 \mathrm{cM}$. A large contiguous portion ( $580 \mathrm{cM}$ ) of LG 1, that had been undetected in previous mapping work, was discovered and is composed of entirely AFLP markers.

An extraordinary variation in the size of linkage groups was observed: > 300 cM (LG1); 200-300 cM (LG2 to LG6); 100-200 cM (LG7 and LG8); <100 cM (LG9 to LG11).
Blair et al. 2003

Freyre et al. 1998

Nodari et al. 1993

Vallejos et al. 1992

Menendez et al. 1997

Ouedraogo et al. 2002a 
70 RAPD markers

$75 \mathrm{~F}_{2}$ plants from GSC01 × GSC02

\section{Soybean $(\mathbf{n}=20)$}

420 new SSR markers

Five populations

452 markers (RFLP + SSR + EST) 184 RILs from Kefeng No.1 $\times$ Nannong 1138-2

436 markers (329 RAPD + 103 SSR + 4 other) 76 RILs from PI 437088A $\times$ Asgrow A3733

\section{SSR markers}

$2 \mathrm{~F}_{2}$ populations from USDA/Iowa State G. $\max \times$ G. soja and Univ. Nebraska Clark $\times$ Harosoy) and RIL population from Univ. Utah Minsoy $\times$ Noi 1

840 markers (165 RFLP + 25 RAPD + 650 AFLP)
The map spanned 474.1 cM across 11 linkage groups, with an average marker distance of $6.87 \mathrm{cM}$. The six linkage groups have $40 \mathrm{cM}$ or more whereas the remaining 5 linkage groups ranged from 4.9 to $24.8 \mathrm{cM}$. The number of markers per linkage group ranged from 2 to 32 . The longest (LG 1) spans $190.6 \mathrm{cM}$ while the shortest (LG 1) is $4.9 \mathrm{cM}$.

Integrated genetic map consisting of 20 linkage groups with a total map length of $2523.6 \mathrm{cM}$ containing 1849 markers (1015 SSRs, 709 RFLPs, 73 RAPDs, 24 classical traits, 6 AFLPs, 10 isozymes, and 12 others), with an average marker density of $1.36 \mathrm{cM}$. The number of new SSR markers added to each linkage group ranged from 12 to 29 but the ratio of SSR marker number to linkage group map distance did not differ among 18 of the 20 linkage groups; however, the SSRs were not uniformly spaced over a linkage group. These clusters of SSRs may be indicative of gene-rich regions of soybean, indicating a significant association of genes and SSRs.

The map consists of 21 linkage groups with a total map length of $3595.9 \mathrm{cM}$, and average marker density of $7.9 \mathrm{cM}$. All the linkage groups except LG F were consistent with those of the consensus map of Cregan et al. (1999).

The 2943 cM genetic linkage map consists of 35 linkage groups that, on the basis of SSR homology, aligned with the 20 known soybean linkage groups.

606 SSR loci mapped in one or more of three populations. Each SSR mapped to a single locus in the genome, with a map order that was essentially the same in all the three populations. The 20 linkage groups derived from each of the three populations could be consolidated into a consensus set of 20 homologous linkage groups presumed to correspond to the 20 pairs of soybean chromosomes.

The 3441 cM map consists of 840 markers grouped into 28 LGs, with an average between marker density of $4.09 \mathrm{cM}$.
Shim et al. 2001

Song et al. 2004

Zhang et al. 2004

Chung et al. 2003

Cregan et al. 1999a

Keim et al. 1997 
for legumes were based on interspecific crosses, usually due to the practical need to use mapping populations with a maximum level of genetic polymorphism when the number of markers available in a crop is relatively low and the cultigen has a low level of genetic variability. An exception to this has been in crops with diverse intra-specific gene pools such as common bean, in which inter-specific crosses were not necessary. Trait-linked markers identified by using inter-specific populations may be useful for introgression/pre-breeding programs but may not be highly valuable for marker-assisted selection in narrow crosses used to develop breeding populations in which the linkage or polymorphism may be lost. This means markers must be generated or validated in a panel of lines/populations representing improved varieties and including the donor genotypes before routine application in a breeding program. Unfortunately, there are very few reports in the literature of marker validation or application in diverse breeding populations. Clearly, a large proportion of legume linkage maps, particularly in lesserstudied crops, are not truly representative of the cultigen genome, although they do offer valuable starting points for the species or genus of interest. There is a large variation in map length both within and between legume species; for example, total map distance ranges from 550 to $2416 \mathrm{cM}$ in pea, 534 to $2483 \mathrm{cM}$ in chickpea, 960 to $1720 \mathrm{cM}$ in common bean, and 474 to $2670 \mathrm{cM}$ in cowpea. This is generally likely to result from differences in the number of chromosomes and total size of the genomes as well as the use of different numbers of markers (increasing the number of markers will generally, until a certain threshold is reached, give larger total map lengths), inclusion of skewed markers (that tend to exaggerate map distances), and use of different mapping softwares (which vary in their estimates of map distances). In addition, many published maps report more linkage groups (LGs) than the haploid chromosome number of that species, for example 9 to 14 LGs in pea $(\mathrm{n}=7), 9$ to 16 LGs in chickpea $(\mathrm{n}=8), 14$ to 16 in broadbean $(\mathrm{n}=6)$, and 20 to 35 LGs in soybean $(n=20)$. This is frequently the result of insufficient marker density, as most saturated maps can be directly aligned with the haploid chromosome complement (Tekeoglu et al. 2002).

Segregation distortion introduces another problem to the development of genetic maps, which is particularly common when using populations from interspecific crosses. This distortion can be due to (i) pre- or postzygotic selection bias due to reduced fitness or lethal effect of certain allelic combinations, (ii) chromosome inversion leading to reduced recombination, and (iii) suppression of recombination at meiosis caused by a non-/or partial homology between chromosomes. This 
distortion can be exacerbated during the tissue culture phase of double haploid (DH) population development or during selection of individuals at each generation of single seed descent during the development of recombinant inbred lines (RILs) mapping populations (Rick 1966; Cheng et al. 1981; Paran et al. 1995; Flandez-Galvez et al. 2003). Skewed segregation in mapping populations can affect both the establishment of linkage groups and the estimation of recombinant frequency. These problems can be minimized by decreasing the recombination fraction used to reject linkage and by limiting the ability to detect linkage among closely co-segregating markers (Wang et al. 1994). Another reason for reduced recombination is the presence of heterochromatin, which due to its more condensed structure has less opportunity for synapsis compared to euchromatin (Tanksley et al. 1992). However, a significant proportion of genes are to be found in these regions which have (especially areas proximal to the centromeres) meiotic crossovers occurring at a rate 5- to 10-fold less than other regions. High-resolution genetic maps will be much easier to generate in regions of higher recombination. For regions of suppressed recombination, much larger progeny sizes will be needed to detect the crossovers necessary for constructing dense genetic maps. Suppression of recombination is also likely to enhance the effects of deleterious "linkage drag" where target genes are introgressed along with genes that convey negative effects on agronomic performances (Stam and Zeven 1981). Excess heterozygosity is also reported to contribute genetic map distances (Knox and Ellis 2002).

The generation of reliable, dense biallelic maps will allow rapid identification of markers for an array of monogenic and polygenic traits, thus facilitating rapid, intensive, and cost-effective study and manipulation of a range of economically and biologically important processes (Cho et al. 1999). Therefore, there is clearly an urgent need to develop saturated genetic linkage maps particularly of the research-neglected crops. The quickest and most cost-effective means of doing this is with co-dominant PCR-based markers (preferably SSRs and SNPs). Increased marker density around genes of interest will provide starting points for chromosome walking, which is the first step in map-based cloning (Tanksley et al. 1992) and will provide sufficient markers for routine marker-assisted breeding. The use of large-insert genomic libraries, especially bacterial artificial chromosomes (BAC), for chromosome walking and for physical mapping of the genome becomes more feasible as the marker density increases (Woo et al. 1994). These libraries are also useful for positional cloning of genes (Arondel at al. 1992) and targeted development of microsatellite markers (Cregan et al. 1999; Meksem et al. 2000). 
Genome-wide physical maps are important tools for genome sequencing, targeted marker development, efficient positional cloning, and highthroughput EST mapping (Marra et al. 1999; Mozo et al. 1999; Chang et al. 2001; Tao et al. 2001; Chen et al. 2002). Amongst the legumes, whole genome physical maps are only available in soybean (Wu et al. 2004a,b), for which a 10x BAC library and a plant-transformation-competent binary large-insert plasmid clone (BIBAC)-based physical map (based on $2905 \mathrm{BAC} / \mathrm{BIBAC}$ contigs spanning $1408 \mathrm{Mb}$ ) have been developed ( $\mathrm{Wu}$ et al. 2004a). When successfully integrating this physical map with the existing soybean composite genetic map using 388 DNA markers, the ancient tetraploid origin of soybean was also confirmed. This provides an important platform for advanced genome research of soybean and other legume species. Wu et al. (2004b) have also developed a 5x largerinsert BAC library in a smaller vector (pECBAC1), using ECoRI. This BAC library contains 38,400 clones; about $99 \%$ of the clones have inserts; the average insert size is $157 \mathrm{kbp}$; and the ratio of vector to insert size is much smaller ( $7.5 \mathrm{kbp}: 157 \mathrm{kbp}$ ) than in the library created for physical mapping, thus providing a much more useful resource for positional cloning. Mudge et al. (2004) used 683 soybean BAC contigs anchored with RFLPs to explore microsyntenic relationships among duplicated regions and examine the physical organization of hypomethylated (gene rich) genomic regions. This study has revealed that RFLPs are physically clustered in less than $25 \%$ of the genome; most of the genes are clustered in less than $275 \mathrm{Mbp}$ of the genome; and approximately $40 \%-50 \%$ of this gene rich portion is associated with RFLP-anchored contigs.

BAC libraries have also been reported for common bean, pea, chickpea, and peanut. The common bean BAC library, from a Sprite snap bean-derived genotype, consists of 33,792 clones and estimated 3- to 5fold coverage of the common bean genome, with an average insert size of the library of around $100 \mathrm{~kb}$ (Vanhouten and MacKenzie 1999). Coyne et al. (2000) constructed a BAC library from a pea germplasm line PI 269818 that represents one genome equivalent and contains 50,000 BAC clones with an average insert size of $110 \mathrm{~kb}$ and packages another 20,000 mini-BACs ( $\leq 60 \mathrm{kbp}$ ) that may be useful in filling gaps in a 5- to 6 -fold coverage library. Thus, the final library consists of approximately 250,000 clones representing 5- to 6-fold haploid genome equivalents, depending on the average insert size of the BAC clones. In chickpea, a BAC library from germplasm line FLIP 84-92C has 23,780 clones representing approximately 3.8 haploid genome equivalents, with an average insert size of $100 \mathrm{~kb}$ (Rajesh et al. 2004). A 10x BAC library in chickpea is also under construction (Cook, pers. commun.). The BAC library in 
peanut contains 182,784 clones representing 6.5 haploid genome equivalents, with an average insert size of $104 \mathrm{~kb}$, and thus allowing the isolation of virtually any single-copy locus (B. Yuksel, pers. commun.).

\section{Molecular Markers for Genes Contributing to Important Agronomic} Traits. Genetic linkage maps have been used for identifying QTL (quantitative trait loci) markers for a wide range of biochemical, physiological, and morphological traits in the model species and major legume crops (Ane et al. 2002). Amongst the crop legumes, soybean, common bean, and pea are the most extensively studied, with QTL markers reported for a number of important agronomic traits including resistance to pests and diseases, abiotic stress tolerance, nitrogen fixation potential, and grain quality (Tables 6.21 and 6.22). Rapid progress is now also being seen in a number of lesser-studied crops, with markers reported for resistance to fusarium wilt in pea, chickpea, broadbean, common bean, and lentil; for ascochyta blight in pea, chickpea, broad-bean, and lentil; for common bacterial blight in chickpea and common bean; for powdery mildew in common bean and mung bean; for rust in broadbean and common bean; for broomrape in broadbean and cowpea; and for anthracnose in common bean (Tables 6.21 and 6.22).

\section{Linkage Disequilibrium and Association Mapping}

Conventional linkage mapping relies on the development of defined genetic populations, which can be used for molecular marker analysis, and identification of genes underlying traits by marker-phenotype correlations (see section $\mathrm{V} \mathrm{B}$ ). The effective mapping of complex traits requires large recombinant inbred line (RIL) (Burr et al. 1988), advanced backcross (Tanksley and Nelson 1996) or double haploid (Kasha and Kao 1970; Chen and Hayes 1989) populations or, alternatively, near-isogenic lines (NILs) (Muehlbauer et al. 1988). These genetic populations or stocks (unlike $\mathrm{F}_{2}$ mapping populations) usually can be readily evaluated in several locations and seasons thus greatly improving the quality of phenotype data to be used for identifying marker associations. However, the development of such populations is time consuming and takes several years. Moreover, any marker-trait associations identified in this way must be validated in independent populations before routine application in breeding programs (Sun et al. 2001). Another drawback to linkage mapping is that it is based on genetic distance and thus is confounded by different recombination patterns within a given physical distance between target loci and marker in different populations. Given the 
Table 6.21. Overview of markers associated with beneficial agronomic traits in tropical grain legume crops.

\section{Common bean}

Angular leaf spot (ALS)

Anthracnose

Bacterial brown spot (BBS)

Bean common mosaic virus (BCMV)
A single dominant gene confers resistance to ALS in MAR-2, and a RAPD marker (OPE-4) has been identified that is linked to the resistance gene at a distance of $5.8 \mathrm{cM}$.

A single dominant gene confers resistance to ALS pathogen race 61.41 in BAT 332. Identified two RAPD markers, OPAA01 $1_{950}(5.1 \mathrm{cM})$ and OPAO12 $2_{950}(5.8 \mathrm{cM})$, linked with resistance to ALS.

AFLP markers (ECAG/MACC-1, EACA/MAGA-2, EAGG/MAAC-8) linked to the Co-1 locus associated with resistance to anthracnose.

Six RAPD markers linked to the Co-4 gene: 4 in coupling and 2 in repulsion phase. Marker OPY20830C is tightly linked $(0.0 \mathrm{cM})$ to $\mathrm{Co}$.

RAPD marker (OPAZ20940) linked in coupling phase at $7.1 \mathrm{cM}$ of the $C o-6$ gene in the $\mathrm{F}_{2}$ populations Rudá × AB136.

RAPD marker (ROH20450) linked to the Mesoamerican Co-2 anthracnose resistance gene, was transformed into a SCAR marker (SCH20) and tested in different genetic backgrounds.

Two RAPD markers linked to the Co- $4^{2}$ allele were identified (OAS13950 and OAL9740) and one dominant SCAR (SAS13) was developed.

Four RAPD markers (OF10530 at 1.9 from the Co1(A) allele and in repulsion-phase; OAB3450 at $5.9 \mathrm{cM}$ from the Co5(Mexique3) allele and in coupling-phase; and OAH1780 and OAK20890 at 12.3 and $7.3 \mathrm{cM}$ from the $\mathrm{Co} 6$ allele and in coupling and repulsion phase, respectively) were developed for differentials.

A genomic region on LG 2 was significantly associated with QTL for BBS resistance.

A RAPD marker, tightly linked (0 cM) with $b c-12$ gene conferring resistance to BCMV, was converted into a SCAR marker (SBD1300) that mapped on LG B3.

A marker for the bc3 gene was obtained from the co-dominant RAPD band ROC11/350/420 and confirmed in different genetic backgrounds.

A SCAR marker (SW13) was developed from the corresponding RAPD primer (OW13690) linked to the I gene, at between 1.0 and $5.0 \mathrm{cM}$ in three $\mathrm{F}_{2}$ populations.
Ferreira et al. 2000

Caixeta et al. 2003

Mendoza et al. 2001

de Arruda et al. 2000

Alzate-Marin et al. 2000

Geffroy et al. 1998

Young et al. 1998

Young and Kelly 1997

Jung et al. 2003

Miklas et al. 2000

Johnson et al. 1997

Melotto et al. 1996; Haley et al. 1994 
Bean golden mosaic virus

(BGMV)

\section{Common}

bacterial

blight (CBB)
One codominant RAPD marker (R2570/530) tightly linked at $4.2 \mathrm{cM}$ to the recessive resistance gene bgm-1.

Fourteen RAPDs linked to 7 QTL conferring resistance to BGMV and/or common bacterial blight.

Major gene located on LG G5, and one QTL each on LG G2, G3, and G5 explained 36.5\%, 10.2\% and $42.2 \%$ of the variation for reaction to CBB, respectively.

SCAR marker BC420 created and analyzed in RIL (HR67 × W1744d) and breeding populations.

QTL study with $78 \mathrm{~F}_{9}$ RILs derived from Great Northern Belneb RR-1 × A 55 for mapping resistant to common bacterial and halo blight as well as bean common mosaic necrosis virus (BCMNV). The linkage map spanned $755 \mathrm{cM}$ and 11 LGs, and contained 87 RAPD markers.

A RAPD marker (BC409.1250) significantly associated with CBB resistance in 3 crosses and all three Xcp species, indicating that it might be tightly linked to the CBB resistance genes.

Two genes for resistance to CBB from XR-235-1-1 were detected, one linked to Bng40 in LG A, one linked to Bng139 in LG F and the last one linked to Bng154 in LG J. Effect of two Calima-derived resistance genes, linked to Bng25a and Bng154 in LG J, were also detected

The two previously identified RAPD markers (R7313 and R4865) located on the same linkage group explained $22 \%$ of the variation in response to CBB in the current mapping population.

QTL study based on a RAPD marker map for the cross PC50 $\times$ XAN159 spanning 426 cM based on 70 RILs and 168 RAPD markers.

Four RAPD markers (R7313, RE416, RE49, and R4865) associated with resistance to CBB.

QTL study based on partial linkage map for the cross BAC $6 \times$ HT 7719 spanning 545 cM and based on 84 markers and 128 RILs analyzed for CBB, web blight and rust.
Urrea et al. 1996

Miklas et al. 1996

Tar'an et al. 2001

Yu et al. 2000

Ariyanthne et al. 1999

Jung et al. 1999

Yu et al. 1998

Ta'ran et al. 1998

Jung et al. 1997

Bai et al. 1997

Jung et al. 1996 
Table 6.21. (continued)

\section{Common bean (continued)}

Fusarium wilt A RAPD marker (U20.750) tightly linked with QTL on LG 10 accounting for 63.5\% of the variation.

Fall et al. 2001

Powdery mildew RAPD markers linked with resistance to powdery mildew were OPRO2-832, OPDO8-759, and OPN10and angular 851 and for angular leaf spot were OPNO2-436 and OPNO7-1072.

leaf spot

Rust

Six RAPD markers in coupling phase linkage, and marker OAB18.650 closely linked (7.6 cM) to Ur-7 gene. All the linked markers detected in $\mathrm{F}_{2}$ also segregated in RILs, and located on LG 11.

Two RAPD markers flanking the rust resistance gene block identified: one at $5.8 \mathrm{cM}$ (OX11630) and the other at $7.7 \mathrm{cM}$ (OF101050) from the gene.

Two SCAR markers SCARBA08 at $4.3 \mathrm{cM}$ and SCARF10 at $6.0 \mathrm{cM}$ from the rust resistance locus.

A RAPD marker OA4.1050 closely linked to the $U r-9$ gene at a distance of $8.6 \mathrm{cM}$.

Two RAPD markers linked to the gene block of interest were identified (OF10970 at $2.15 \mathrm{cM}$ and OI19460 at $0.0 \mathrm{cM}$ in a 97 individual $\mathrm{BC}_{6} \mathrm{~F}_{2}$ population.

A RAPD marker OA141100 linked to the dominant $U r 2$ gene in an 84 individual $\mathrm{BC}_{6} \mathrm{~F}_{2}$ population.

White mold

2 QTL conferring resistance to white mold, located on LG B6 and B8, contributing 13\% and $26 \%$ of the disease reaction in the field, respectively.

QTL affecting partial physiological resistance, partial field resistance, and porosity over furrow were reported.

Drought

Nodulation and common bacterial blight (CBB)

4 and 5 QTLs identified for drought tolerance in two recombinant inbred populations (Sierra/AC1028 and Sierra/Lef-2RB), respectively grown under stress and non-stress conditions at eight locations.

Four QTL associated with increased number of nodules and resistance to Xanthomonas, suggesting a common genetic control for response to bacterial infection in common bean.

Four QTL identified in the same genomic region for resistance to CBB and nodulation which accounted for $75 \%$ and $50 \%$ phenotypic variation for CBB and nodulation, respectively.

Melo et al. 2002

Park et al. 2003

Faleiro et al. 2000

Correa et al. 2000

Park et al. 1999

Haley et al. 1993

Miklas et al. 1993

Miklas et al. 2003

Park et al. 2001

Schneider et al. 1997

Souza et al. 2000

Nodari et al 1993

QTL analysis of nodule number (NN) and CBB resistance in a 70 individual $\mathrm{F}_{2}$-derived $\mathrm{F}_{3}$ families of BAT93 $\times$ Jalo EEP-558 identified 8 QTLs for NN of which 4 were shared for CBB resistance.

Tsai et al. 1998 
Cooking time

Nutritional traits

Agronomic traits

Canning quality

Domestication syndrome

\section{Cowpea}

Earliness and seed weight

Striga
A RAPD marker (UNAM-16) of 300 bp explained $23 \%$ of the variation in cooking time of the lines studied.

Five putative QTL significantly associated with seed mass, two with Ca, two with Fe, one with Zn, and four with tannin content in the seed, explaining $42 \%, 25 \%, 25 \%, 15 \%$, and $41 \%$ of the phenotypic variation, respectively.

Twenty QTL identified for 14 traits: the number ranged from one to three, and accounted for $11.3-43.1 \%$ variation for the traits.

Degree of splitting (SPLT) and overall appearance (APP) determines the canning quality. Major QTL identified on two linkage groups: one QTL linked with 7 RAPD markers on B8 LG of the core map; the second QTL linked with 4 markers but not assigned to core LGs.

Three genomic regions are reported to have major effect on domestication traits (loss of seed dispersal, seed dormancy, determinate growth habit, fruit size, and seed weight) in common bean: one region greatly affects growth habit and phenology; the other seed dispersal and dormancy; and a third, the size of fruit and seed.

A gene for earliness mapped on LG 2 in an interval spanning $26 \mathrm{cM}$ around RFLP marker locus D1301a, accounting for $21 \%$ of the phenotypic variation. A RAPD marker OB6a on LG 5 accounted for $9 \%$ of the phenotypic variation in seed weight.

Three and six AFLP markers tightly linked to Rsg2-1 and Rsg4-3 loci conferring resistance to $S$. gesnerioides race 1 from Burkina Faso and to race 3 from Nigeria, respectively. Two markers linked to both Rsg2-1 and Rsg4-3.
Jacinto-Hernandez et al. 2003

Guzman-

Maldonado et

al. 2003

Tar'an et al. 2002

Posa-Macalincag et al. 2002

Koinange et al. 1996

Menendez et al 1997

Ouedraogo et al. 2001 
Table 6.21. (continued)

Trait Summary of the QTL identified Reference

\section{Cowpea}

Striga (cont.)

Agronomic traits

Aphid

Cucumber mosaic virus (CMV)

\section{Mungbean}

Powdery mildew
Seven AFLP markers linked to Rsg3, the gene conferring resistance to race 1 in Gorom, with two markers (E-AGA/M-CTA460 and E-AGA/M-CAG300) flanking Rsg3 at 2.5 and $2.6 \mathrm{cM}$, respectively. Five AFLP markers linked to the race 1 resistance gene 994-Rsg present in IT81D-994. The two markers showing the tightest linkage to the 994-Rsg locus are E-AAG/M-AAC450 and E-AAG/MAAC150 at 2.1 and $2.0 \mathrm{cM}$, respectively. Two of the markers linked to 994-Rsg, E-AGA/M-CAG300 and E-AGA/M-CAG450, are also linked to Rsg3.

Four AFLP markers (E-ACT/M-CTC ${ }_{115}$, E-ACT/M-CAC ${ }_{115}$, E-ACA/M-CAG ${ }_{108}$, and E-AAG/M-CTA 190 ) mapped at 3.2, 4.8, 13.5, and $23.0 \mathrm{cM}$, respectively, from the $R s g 1$ gene that confers resistance to Striga race 3 in IT93K-693-2. A SCAR marker (SEACTMCAC83/85) was also developed from an AFLP fragment from E-ACT/M-CAC that may be useful in breeding programs.

QTL detected for leaf length and width, primary leaf length and width, leaf area, days to flowering, maturity, pod length, and seed/pod weight. Several regions of the genome affected more than one trait.

A tightly linked RFLP marker (bg4D9b) associated with aphid resistance gene (Rac1) and several flanking markers in the same linkage group reported.

Cry gene in Kurodane-Sanjaku confers resistance to CMV. RAPD markers D13/E14-350 (5.2 cM), WA3850 (11.5 cM), OPE3-500 (24.5 cM) and RGA (CRGA5 at $0.7 \mathrm{cM})$ were found associated with cry locus.

A major QTL accounted for $64.9 \%$ of the variation in resistance to powdery mildew.

Three genomic regions together contributed $58 \%$ of the total phenotypic variation associated with resistance to powdery mildew.
Ouedraogo et al. $2002 b$

Boukar et al. 2004

Ubi et al. 2000

Myers et al. 1996

Chida et al. 2000

Chaitieng et al. 2002

Young et al. 1993 
Bruchid

A single dominant gene, $B r$, confers resistance to bruchid in TC1966. Eight RAPD-based markers, one mungbean and four common bean genomic clones effectively integrated around $\mathrm{Br}$ within a $3.7 \mathrm{cM}$ interval. $\mathrm{Br}$ gene mapped to a $0.7 \mathrm{cM}$ segment between a cluster consisting of 6 markers and a common bean RFLP marker, Bng110.

\section{Pigeonpea}

Cytoplasmic male sterility (CMS)

\section{Soybean}

Yield

Seed size

Seed yield, and oil and protein content

Seed weight

Sprout yield

Seed

Isoflavone
A RAPD marker, OPC-11 (600 bp) associated with male sterility in 288A and 67A but absent in the maintainer (288B and 67B) and restorer (TRR 5 and TRR 6) lines.
Concibido et al. 2003

Hoeck et al. 2003 variation in population 1; 16 markers accounted for 7.8 to $36.5 \%$ variation in population 2 ; and 22 markers accounted for 8.6 to $28.8 \%$ variation in population 3 .

A seed protein, oil, and yield QTL mapped close to RAPD marker (OPAW13a) in a small LG-I interval flanked by the SSR markers Satt496 and Satt239.

Three and five markers significantly associated with seed weight variation in the $\mathrm{F}_{2}$ and $\mathrm{F}_{3}$ populations and together they explained $50 \%$ and $60 \%$ of the phenotypic variation, respectively.

Four QTL associated with sprout yield located in the same genomic region as the QTL for seed weight. This reveals that either QTL for sprout yield are genetically linked to seed weight QTL or else that seed weight QTL pleiotropically condition sprout yield.

Six QTL significantly associated with seed isoflavone content.
Kaga and Ishimoto 1998

Souframanien et al. 2003
Chung et al. 2003

Maughan et al. 1996

Lee at al. 2001

Meksem et al. 2001a;

Kassem et al. 2004

(continued) 
Table 6.21. (continued)

\section{Soybean (cont.)}

Water use effici- A total of 4 and 6 independent RFLP markers linked with WUE and LASH together explained 38\% and ency (WUE) and leaf ash (LASH)

WUE $53 \%$ of the variability, respectively. A major QTL on USDA LG J explained $13.2 \%$ of the variation in WUE. LASH was negatively correlated with WUE and two QTL were associated with both WUE and LASH.

Two independent RFLP markers (A063E and A489H) associated with WUE. A063E was also linked with WUE in the Young $\times$ PI416937 population. Marker A489H explained 14\% of the variation in WUE.

Drought tolerance

Major QTL detected for yield beta, yield, and carbon isotope discrimination.

Salt tolerance

A major QTL for salt tolerance close to the Sat_091 SSR marker on LG-N accounted for $41 \%, 60 \%$, and $79 \%$ of the total genetic variation in the field, greenhouse, and combined environments, respectively.

Soybean mosaic virus (SMV) and peanut mottle virus $(\mathrm{PMV})$

Corn earworm

\section{Cyst} nematode
$6.8 \mathrm{cM}$ region around Rsv1 and Rpv1, resistant genes, mapped using over 20 RFLP, RAPD, and microsatellite markers. The Rsv 1 and $R p v 1$ are tightly linked at a distance of $1.1 \mathrm{cM}$.

One major and two minor QTL associated with resistance to corn earworm. The major QTL is linked with RFLP marker 584 on LG M of the USDA/Iowa soybean genetic map, and contributes $37 \%$ of the total variation for resistance.

A major QTL conferring resistance to cyst nematode mapped to the region containing rhg1 on LG G and to the region containing Rhg4 on LG A2. Mapping of many different sources of resistance revealed QTL in this same region suggesting that these diverse sources may share common genes for resistance. Candidate genes for rhg1 and Rhg4 have also been cloned.
Mian et al. 1996

Mian et al. 1998

Specht et al 2001

Lee et al. 2004

Gore et al. 2002

Rector et al. 1998

Concibido et al. 2004 
Root-knot

nematode

Peanut

root-knot

nematode

Sudden death syndrome (SDS)

Agronomic traits

Iron

deficiency

chlorosis

Flowering, maturity, and photoperiod insensitivity
Two QTL associated with resistance to root-knot nematode were located on two LGs: RFLP marker B212-1 on LG F and A725-2 on LG D1 accounted for 46\% and 13\% of the variation in gall number, respectively.

Two QTL conferring resistance to peanut root-knot nematode identified: one mapped at 0-cM from RFLP marker B212V-1 and accounted for 32\% variation in gall number, whereas another mapped between $\mathrm{B} 212 \mathrm{D}-2$ to $\mathrm{A} 111 \mathrm{H}-2$ and accounted for $16 \%$ of the variation.

Two QTL identified by RAPD markers, OO05250 and OC01650, associated with mean SDS response and together contributed $34 \%$ of the total phenotypic variation.

63 QTL that had LOD>3 for 9 agronomic traits mapped on 12 LGs. Seven ESTs linked closely with or located at the same loci as the QTL. EST marker, GmK.F0590, accounted for $20 \%$ of the total variation for 4 agronomic traits.

Major QTL identified for plant height, lodging, flowering, reproductive period, maturity, yield, seed weight, and seed oil and protein contents.

QTL with minor effects detected on six linkage groups of the Pride B216 $\times$ A15 population, whereas one major QTL detected in population Anoka × A7.

Time to flowering, maturity, and photoperiod insensitivity is controlled by a major QTL with large effect, modified by several minor QTL, all three QTL are located in the same region on LG C2 in both populations.
Tamulonis et al. 1997a

Tamulonis et al. $1997 b$

Hnetkovsky et al. 1996

Zhang et al. 2004

Mansur et al. 1996; Brummer et al. 1997; Orf et al. 1999

Lin et al. 1997

Tasma et al. 2001 
Table 6.22. Overview of markers associated with beneficial agronomic traits in temperate grain legumes.

\section{Broadbean}

Broomrape

Seed weight

Rust

Ascochyta blight

\section{Chickpea}

Ascochyta blight
Three QTL confer resistance to broomrape, and together accounted for 74\% of the variation. One QTL explained more than $35 \%$ of the phenotypic variance whereas the others accounted for 11.2 and $25.5 \%$, respectively.

Several QTL for seed weight; the most important of which, located on chromosome 6, explained about $30 \%$ of the total phenotypic variation.

Three RAPD markers in coupling phase (OPD13736, OPL181032, and OPI20900) and two in repulsion phase (OPP021172 and OPR07930) mapped to the resistance gene for race 1 (Uvf-1). No recombination detected between OPI20900 and $U f_{V}-1$.

Two putative QTL, Af1 and Af2, identified on LGs VIII and IVa and together explained $46 \%$ of the total phenotypic variation for resistance to Ascochyta blight.

Two QTLs conferring resistance to Ascochyta blight accounted for $45.0 \%$ and $50.3 \%$ phenotypic variation in 1997 and 1998, and mapped to LG 6 and LG 1, respectively. Two RAPD markers flanking the first QTL were $10.9 \mathrm{cM}$ apart while one ISSR and enzyme marker flanking the second QTL were $5.9 \mathrm{cM}$ apart.

A major locus, ar1 mapped on LG 2, conferring resistance to Ascochyta blight pathotype 1 and two independent recessive major loci, ar2a on LG2 and ar2b on LG4, conferring resistance to pathotype 2. ar2a is tightly linked to ar1 indicating a clustering of resistance genes in that region of the chickpea genome.

Resistance to Ascochyta blight is encoded by 2-3 QTL. OPS06-1 and OPS03-1, located on LG 4, were linked to markers UBC733B and UBC181A flanking the major Ascochyta blight locus. The former mapped at the peak of QTL between UBC733B (4.1 cM) and UBC181A (9.6 cM) while the latter mapped $25.1 \mathrm{cM}$ away from UBC733B. Three of these markers closely linked to the major QTL.

A major QTL for resistance to Ascochyta blight, located close to the locus of the OPAC04/1200 marker, explained 20 to $23.7 \%$ of the total phenotypic variation.
Roman et al. 2002

Vaz-Patto et al. 1999

Avila et al. 2003

Roman et al. 2003

Santra et al. 2000

Udupa and Baum 2003

Rakshit et al. 2003

Millan et al. 2003 
Double podding

Agronomic traits

Nodulation and common bacterial blight (CBB)

\section{Grasspea}

Ascochyta blight that has been mapped $0.6 \mathrm{cM}$ from SSR markers TA96 and TA27 and STMS marker CS27A. Another SSR marker, TA194, at $14.3 \mathrm{cM}$, flanked the gene on the other side. Established the linkage between foc-3 and two other chickpea wilt resistance genes, foc-1 (syn. $\mathrm{h}_{1}$ ) and foc-4. Foc-3 was mapped 9.8 cM from foc-1 and $8.7 \mathrm{cM}$ from $f o c-4$, whereas foc- 1 and $f o c-4$ are closely linked at $1.1 \mathrm{cM}$.

A RAPD marker (OPJ20600) linked with resistance to fusarium wilt.

Linkage analysis indicated that the genes for resistance to races 4 and 5 were on the same LG and were separated by $11.2 \mathrm{cM}$. The gene for resistance to race 0 was not linked to the race 4 and 5 resistance genes. An allele-specific marker (CS-27R/CS-27F) was located between the two-resistance genes and was 7.2 and $4 \mathrm{cM}$ from the genes for resistance to races 4 and 5 , respectively.

Two RAPD markers (CS 27700 and UBC 170550) located 9 cM from the race 4-resistance locus, were on the same side of the resistance gene. The genes for resistance to race 1 and 4 are $5 \mathrm{cM}$ apart.

An ISSR marker (UBC-855500) linked to fusarium wilt race 4 resistance gene at a distance of $5.2 \mathrm{cM}$. It co-segregated with CS 27700, a RAPD marker previously shown to be linked to fusarium wilt resistance race 1 gene, and mapped to LG 6.
A gene that confers double podding, gene symbol " $s$ ", is important for breeding high yielding chickpea cultivars. A SSR marker, TA-80, was located at $4.84 \mathrm{cM}$ from the " $s$ " locus.

Four QTL identified for 100-seed weight (on LG 4 and LG9), seed number per plant (LG 4), and days to $50 \%$ flowering (LG 3). A double podding gene mapped to LG 6 was linked to $\operatorname{Tr} 44$ and $\operatorname{Tr} 34$ at a distance of $7.8 \mathrm{cM}$ and $11.5 \mathrm{cM}$, respectively.

For each trait, at least four putative QTL identified, which accounted for $50 \%$ and $75 \%$ of the phenotypic variation in nodule number and CBB resistance.
Sharma et al. 2004

Rubio et al. 2003

Tekeoglu et al 2000

Tullu et al. 1998

Ratnaparkhe et al. 1998

Rajesh et al. 2002

Cho et al. 2002

Nodari et al. 1993

Skiba et al. 2004 for resistance to Ascochyta blight, respectively, in the backcross population of the cross ATC $80878 \times$ ATC 80407. 
Table 6.22. (continued)

Trait

Summary of the QTL identified

Reference

\section{Lentil}

Anthracnose

Ascochyta

blight

Frost injury

Fusarium wilt

Pea

Resistance to lodging and mycospharella blight

Fusarium wilt race 1

Fusarium wilt, powdery mildew, and pea common mosaic virus (PCMV)
A major dominant gene, LCt-2, confers resistance to anthracnose in PI 320937, and 2 flanking RAPD and 3 AFLP markers linked to the LCt-2 locus.

A single recessive gene, ra12, confers resistance to Ascochyta blight in Indianhead cultivar. Two flanking RAPD marker, UBC227 ${ }_{1290}$ and OPD-10 ${ }_{870}$, linked in repulsion phase to the gene ra12 at 12 and $16 \mathrm{cM}$, respectively.

Tolerance to frost is monogenic, and a RAPD marker (OPS 16750) linked to the locus for radiation-frost tolerance (Frt) trait at $9.1 \mathrm{cM}$.

A single dominant gene $\left(F_{W}\right)$ confers resistance to fusarium wilt, and a RAPD marker (OPK 15900) located at a distance of $10.8 \mathrm{cM}$. Two other RAPD markers in coupling (OP-B17800 and OP-D15500) and another in repulsion (OP-C04650) phase were found associated with resistance to Fusarium wilt.

Two QTL associated with resistance to lodging together contributed $58 \%$ of the phenotypic variation. Three QTL each for plant height and mycospharella blight resistance accounted for $65 \%$ and $36 \%$ of the total phenotypic variation, respectively. These QTL were relatively consistent across environments. The AFLP marker associated with the major locus for lodging resistance was converted into a SCAR marker that corresponds well with the lodging reaction of 50 pea varieties.

Single dominant gene confers resistance to fusarium wilt race 1, and an AFLP marker (ACG:CAT_222) has been located within $1.4 \mathrm{cM}$ of the $F_{W}$ gene.

Molecular markers linked with resistance to fusarium wilt (6 cM from $F_{W}$ ), powdery mildew (11 cM from er), and PCMV ( $15 \mathrm{cM}$ from $\mathrm{mo}$ ) have been reported, and three QTL explained most of the variation associated with resistance to Ascochyta blight race C.
Tullu et al. 2003

Chowdhury et al. 2001

Eujayl et al. 1999

Eujayl et al. 1998b

Tar'an et al. 2003b

McClendon et al. 2002

Dirlewanger et al. 1994 
Aphanomyces root rot

Ascochyta

blight and/or

plant

maturity
A major QTL, Aph1, that explained up to $47 \%$ of the variation, and few minor QTL associated with resistance to aphanomyces root rot.

Six QTL detected at the seedling stage together explained up to $74 \%$ of the variance and 10 QTL detected at the adult plant stage in the field accounted for 56.6-67.1\% of the variance. Four QTL were identified under both growth chamber and field conditions suggesting that these loci were not plant growth-stage specific. A few QTL for flowering and plant height were co-located with QTL for resistance.

Eleven and fourteen QTL detected for resistance to Ascochyta blight in A26 $\times$ Rovar and A88 $\times$ Rover populations, respectively. Of these, six QTL were associated with the same genomic regions in both the populations that reside on LG-II, III, IV, V, and VII (2 QTL). For plant maturity, six QTL were detected in the A26 $\times$ Rovar while five QTL mapped in the A88 $\times$ Rovar populations. QTL for plant maturity coincide with Ascochyta blight resistance QTL in four genomic regions: LG II (two regions), III, and V, linked either in repulsion or coupling phase.

Eight of 13 QTL associated with resistance to Ascochyta blight were detected in multiple environments.

Pea seed born mosaic virus (PSbMV)

Powdery mildew

Green seed color

Seed weight

Grain yield, seed protein,
An STS marker (sG05_2537) located approximately 4 cM from the sbm1 gene that confers resistance to PSbMV.

An RFLP marker (GS185) about 8 cM from the sbm-1, the gene for resistance to PSMV.

Three RAPD primers in coupling (OPO-18, OPE-16, and OPL-6) and two in repulsion phase (OPE161600 and OPL-61900) linked to powdery mildew resistance gene, er-1.

Two major QTL affecting seed color: QTL 1 and QTL 2 account for $61 \%$ and $56 \%$ variation of the variation for seed lightness and seed hue, respectively.

A common seed weight QTL mapped to the same region of LG III in two crosses.

Across 13 environments, four QTL identified each for grain yield and maturity and 3 QTL for seed protein concentration that accounted for $39 \%, 45 \%$, and $35 \%$ of the total phenotypic variation, respectively.
Pilet-Nayal et al. 2003

Prioul et al. 2004

Timmerman-Vaughan et al. 2004

Timmerman-Vaughan et al. 2002

Frew et al. 2002

Timmerman-Vaughan et al. 1993

Tiwari et al. 1998

McCallum et al. 1997

Timmerman-Vaughan et al. 1996

Tar'an et al. 2004 
limitations of conventional linkage mapping, there has been considerable interest recently in the development of methodologies that do not require the creation of mapping populations for each trait and that generate markers that can be more immediately applicable in diverse breeding programs.

Linkage disequilibrium (LD) and genetic association mapping analyses are means of identifying a close association between genes contributing to target traits and marker loci using a structured collection of diverse germplasm (Thornsberry et al. 2001). LD mapping relies on population-level associations between target loci and nearby markers and has been extensively employed for mapping disease traits in mammals in which genetic populations are more difficult to develop. LD itself typically arises when all or most of the target alleles in a population share a common ancestral origin and a species or crop has undergone an evolutionary bottleneck. Most importantly, the LD approach is based on the use of natural or human-selected populations of plants rather than genetic populations. Moreover, LD mapping has the advantage that resultant markers tend to be both genetically and physically close to the gene of interest and therefore more readily applicable in a diverse range of breeding programs. The fundamentals of LD mapping have been reviewed in detail elsewhere (Boreck and Suarez 2001; Nordborg and Tavare 2002; Flint-Garcia et al. 2003; Rafalski and Morgante 2004).

In contrast to the numerous linkage disequilibrium (LD) studies in humans and other mammals, there are very few publications on this topic in agriculturally important crops including legumes (Virk et al. 1996; Beer et al. 1997; Pakniyat et al. 1997; Forster et al. 1997; Igartua et al. 1999; Remington et al. 2001; Thornsberry et al. 2001; Turpeinen et al. 2001; Hansen et al. 2001; Sun et al. 2001, 2003; Skot et al. 2002; Ivandic et al. 2002, 2003; Amirul Islam et al. 2004; Zhu et al. 2003a; Simko et al. 2004; Sabharwal et al. 2004). Traditionally, the plant community has been reticent to use LD mapping, believing that it can lead to spurious and non-functional associations due to mutation, genetic drift, population structure, breeding systems and selection pressure (Hill and Weir 1994; Pritchard et al. 2000). However, most of these limitations are being overcome in recent mammalian studies by following precautions that minimize circumstantial correlations and maximize the accuracy of association statistics. Unfortunately, the real value of LD mapping in plants remains to be demonstrated, as most of the reports to date are based on small population sizes or a limited number of markers and generally lack validation. 
The most powerful LD analyses take account of two types of recombination: (i) unique or rare recombination between members of different populations or species (between different parts of the genome); and (ii) repeated recombination within a population between homologous sites. The analytical methods appropriate in the former context are inappropriate in the latter because they depend on recognizing the existence of runs of nucleotides with similar ancestry (Smith 1999). It is also important to determine the optimum number of markers required, which depends on the extent of disequilibrium and on how finely loci are to be mapped (Altshuler et al. 2000). In general, LD studies have tended to use a large number of markers selected from high-density linkage maps available in many mammalian systems. This number of markers is not available in most legumes, so a compromise number must be determined.

Initial LD mapping studies have been conducted in the model plant Arabidopsis thaliana, which is characterized by a high level of polymorphism and extensive haplotype structure and thus provides a highly appropriate scenario for association mapping (Hagenblad and Nordborg 2002). In a study of the FRI locus, Nordborg et al. (2002) found that LD decays at a distance of roughly $1 \mathrm{cM}$ or $250 \mathrm{kbp}$ in Arabidopsis compared to one to a few kbp in maize. Meanwhile, a study on patterns of local and genome-wide linkage decay around six genes in maize inbreds using SSR and SNP loci revealed that intra-genic linkage decay generally declined rapidly with distance $\left(\mathrm{r}^{2}<0.1\right.$ within $\left.1500 \mathrm{bp}\right)$, but that rates of decline were highly variable among genes. This rapid decline of LD in maize probably reflects the large effective population size during maize evolution and high levels of recombination within genes. Provided the effects of population structure are effectively controlled, this research suggests that association studies can help to identify the genetic basis of important traits in maize (Remington et al. 2001). Association mapping between DNA markers and agronomic characters in a collection of plant genetic resources would allow (i) assessment of the genetic potential of specific genotypes prior to phenotypic evaluation, (ii) identification of superior trait alleles in germplasm collections, (iii) high resolution QTL mapping, and (iv) validation of candidate genes responsible for quantitative agronomic characters (Gebhardt et al. 2004). In a recent large-scale study in potato, association mapping was carried out using a gene bank collection of 600 cultivars of potato (Solanum tuberosum ssp. tuberosum) bred between 1850 and 1990 (Gebhardt et al. 2004). Highly significant associations were identified with QTL for resistance to late blight (Phytophthora infestans) and plant maturity. They also 
traced introgression of marker alleles associated with increased resistance and late maturity from the wild species $S$. desmissum. Other studies have detected associations between quantitative traits and RAPD markers, with Virk et al. (1996) predicting the performance of rice accessions. Similarly, RFLP markers were associated with quantitative traits in oats (Beer et al. 1997); however, most of these markers were not validated during QTL mapping of a population derived from a cross between 'Kanota' and 'Ogle'. Using association mapping, Sabharwal et al. (2004) identified 15 AFLP markers obtained from eight AFLP primer combinations associated with seed-coat colour in 39 Brassica juncea lines, two of which (E-ACA/M-CTG ${ }_{350}$ and E-AAC/M-CTC ${ }_{235}$ ) were validated in recombinant inbred populations associated with yellow and brown seed-coat color, respectively. Kraakman et al. (2004) reported association between AFLP markers and complex quantitative traits such as mean yield, adaptability (Finlay-Wilkinson slope), and stability (deviations from the regression) in a collection of 146 modern two-rowed spring barley cultivars trial data. Regression of those traits on individual marker data disclosed marker-trait associations for mean yield and yield stability. In addition, many of the associated markers were located in the regions where earlier QTL were found for yield and yield components, thus demonstrating that association mapping can be a viable alternative to classical QTL analyses based on crosses between inbred lines, especially for complex traits with costly measurements.

LD mapping has also been carried out using SNP haplotype analysis of 25 diverse soybean accessions that revealed a low level of linkage decay and a deficiency in the number of haplotypes (Zhu et al. 2003a). This lack of genome-wide linkage decay coupled with the low haplotype diversity suggested that the cultivated soybean genome was a mosaic of a limited number of haplotypes that may have resulted from recombination among three or four ancestral haplotypes. A recent study in common bean by Amirul Islam et al. (2004) showed that about $10 \%$ of the accessions in the CIAT core collection exhibited evidence of introgression between the Andean and Mesoamerican gene pools and that RAPD markers associated with these introgressions were associated with several morphological, economic, and nutritionally important characteristics.

\section{Dissection and Manipulation of Legume Physiology}

The public release of the entire genome sequence of $A$. thaliana and rice, and the rapid progress being made in sequencing the gene space of other major crops (including maize and soybean) and model legumes (M. trun- 
catula and L. japonicus) provide the basis for new approaches to plant research and breeding that may now be largely anchored to specific gene sequences and their putative functions. Because of the similarities between genes that code for the same trait in different species, comparative genomics will become an essential tool for technological leapfrogging from major crops and model systems to many related crops. Meanwhile, transgenic technologies have the potential to facilitate quantum leaps in improvements in economically important metabolic pathways that can be drastically influenced by a small number of genes. The current adoption, success and failures, and future prospects of transgenic crop varieties has been reviewed in detail elsewhere (Chandra and Pental 2003; Halford 2004; Popelka et al. 2004). To date, the most widely grown transgenic crops are soybean ( $33.3 \mathrm{~m} \mathrm{ha})$ and maize $(9.8 \mathrm{~m} \mathrm{ha})$ with herbicide tolerance or insect pest resistance (James 2003). The products from these new crops are now incorporated into a wide range of processed foods that include altered protein, starch, or oil quality; and improved micronutrient or vitamin content (Dunwell 1998). There has also been large-scale adoption of cotton ( $6.8 \mathrm{~m} \mathrm{ha}$ ) and canola ( $2.7 \mathrm{~m} \mathrm{ha}$ ) with the same herbicide tolerance or insect pest resistance transgenes (James 2003). Six countries grew 99\% of the global transgenic area (67.7 $\mathrm{m} \mathrm{ha}$ ) in 2003: USA (42.8 m ha), Argentina (13. $9 \mathrm{~m} \mathrm{ha}$ ), Canada (4.4 m ha), Brazil (3 m ha), China (2.8 $\mathrm{m} \mathrm{ha}$ ), and South Africa (0.4 m ha) (James 2003; http://www.isaaa.org/kc).

Recent developments in legume genomics are also providing an array of molecular breeding opportunities to legume breeders. The critical advances include the availability of a large number of robust PCR-based markers such as SSR, ESTs, and SNPs and the generation of high-density genetic maps. At the same time, the generic advances in automation technologies now offer real possibilities for the efficient development and application of marker-assisted selection techniques at a scale and unit cost that is finally of relevance to plant breeding programs and international germplasm collections. Meanwhile, developments in microarray technology promise a new paradigm of simultaneous selection for a diverse range of complex traits.

Among the traits of interest, the exploitation of genomics, transgenics, and molecular breeding will allow legume breeders to enhance pest and disease resistance, increase environmental stress tolerance, improve symbiotic nitrogen fixation, and develop nutritional quality (biofortification) in the future.

Plant breeders have been successful in creating new high-yielding cultivars in many crops by incorporating just a few genes, i.e., those 
involved in plant height and photoperiodism (Miflin 2000). However, continued improvement has been increasingly complex and difficult. Manipulating components of yield is confounded by the highly complex genetic nature of this trait in which there is substantial interaction between underlying genes (epistasis), and significant environmental dependency of gene expression (Ribaut and Hoisington 1998).

Many of the most agronomically and economically important traits (i.e., drought, salinity, yield, and nutritional quality) in most crops have quantitative phenotypic variation, are under polygenic control, and are significantly affected by the environment. These traits are, therefore, very difficult and time consuming to manipulate in conventional breeding programmes. These factors are also at least as troublesome during the identification of trait-based genetic markers. Moreover, the expertise, the time, and expense required to generate appropriate phenotype data for QTL mapping should never be underestimated. However, once effective and reliable markers have been identified, substantial progress can be made in the speed and precision of manipulating these traits in breeding programs.

Whole plant physiology modeling is becoming an increasingly important tool for aiding improvement in breeding efficiency of complex traits. These models help define crop ideotypes for different environments. QTL mapping is carried out for physiological components that are more likely to relate directly to gene expression. Modeling can then be used to extrapolate information to a new environment (Podlich and Cooper 1998; Cooper et al. 2002; Chapman et al. 2002, 2003; Yin et al. 2003, 2004).

Using the ideotype approach, Chinese researchers have developed superhybrid rice by incorporating a few morpho-physiological traits such as long, narrow, and erect top leaves and large panicles that hang close to the ground to enhance the efficiency of crop light capture (Setter et al. 1995). In field trials at four separate locations in China, these superhybrids produced $15 \%$ to $20 \%$ higher yields than existing hybrids that already generated $10.5 \mathrm{t} \mathrm{ha}^{-1}$ (Normile 1999). Based on the complimentary aspects of modeling and mapping, Yin et al. (2003) proposed an approach that integrates marker-assisted selection (MAS) into the model-based ideotype framework to support breeding for improved crop yield. For this approach to be effective, there is a need to develop crop models capable of predicting yield differences among genotypes in a population under various environmental conditions.

System biology attempts to discover and understand biological properties that emerge from the interaction of many system elements (Ideker et al. 2001; Kitano 2002). It examines the structure and dynamics of cellular and organismal function, rather than the characteristics of isolated 
parts of a cell or organism. The substantial progress in molecular biology, particularly in genomics, proteomics, and high-throughput measurements, has facilitated researchers to collect comprehensive datasets on the mechanisms underlying plant growth and plant responses to perturbations. A plant requires information about its environment and its interaction with that environment and uses that information to dictate its adaptive responses that result in the plant phenotype. Significant endeavors in the field of whole-plant modeling are now being directed at understanding genetic regulation and aiding crop improvement (Hammer et al. 2002; Cooper et al. 2002; Chapman et al. 2003; Yin et al. 2003, 2004). Crop models with generic approaches to underlying physiological processes (Wang et al. 2002) provide a means to link phenotype and genotype through simulation analysis to provide what is being termed the "in silico plant." Modern genomics has enormous potential for generating huge amounts of information about individual components in the genotype to phenotype pathway. Whole plant physiology modeling offers a means of reconstructing the entire pathway and thereby providing a critical link between molecular genetics and crop improvement. Important progress in this area has already been made for leaf growth in maize (Zea mays L.) in response to temperature and water deficit (Raymond et al. 2003), photoperiod responses in sunflower (Helianthus annuus L.) (Leon et al. 2001), stay green trait in sorghum (Sorghum bicolor L.) (Borell et al. 2001), specific leaf area in barley (Hordium vulgare L.) (Yin et al. 1999), and tolerance to water deficit in various crops (Tardieu 2003).

1. Enhancing Stress Tolerance. Drought and salinity are major abiotic factors limiting legume productivity. In this context, the development of enhanced tolerance or avoidance mechanisms is a critical element in ensuring yield stability in many target environments. Despite intensive efforts over the past 50 years or more, the identification and utilization of drought and/or salinity tolerance traits in conventional breeding programs has been generally unsuccessful. New knowledge and tools from the rapid progress in legume genomics and functional genomics are identifying a cascade of regulatory genes that open new possibilities for altering plant architecture and metabolism that will undoubtedly contribute to breaking the current impasse in stress tolerance breeding.

Drought Tolerance. The necessary tools and methods for characterizing drought environments, sources of drought tolerance, and drought tolerant traits (root characteristics, photosynthate partitioning, water use efficiency, etc.), in addition to our ability to rapidly advance generations 
using marker-assisted selection, are now available to help us embark upon a focused program of genetic enhancement for drought tolerance using trait-based molecular breeding. For instance, an ideotype approach was adopted at ICRISAT for genetic improvement of drought tolerance in chickpea (Saxena 2003). Concurrent selection for drought-tolerant traits, disease resistance, and yield in early segregating generations is essential to develop viable new varieties.

Several gene transfer approaches have been attempted with the objective of improving the stress tolerance of plants both based on single genes or a product of a regulatory gene that activates a whole cascade of other gene products in the plant stress response pathway (Holmberg and Bulow 1998). Genetically engineered plants for single gene products include those encoding for enzymes required for the biosynthesis of osmoprotectants (Hayashi et al. 1997), modified membrane lipids (Ishizaki-Nishizawa et al. 1996), a LEA (late embryogenesis abundant) protein (Xu et al. 1996), and detoxification enzymes (Mckersie et al. 1996). Similarly, many genes that are thought to be involved in stress response can be simultaneously regulated by using a single gene encoding, a stress-inducible transcription factor (Kasuga et al. 1999). $D R E B / C B F$ genes are a small family of transcription factors that bind to the drought-responsive elements (DRE) found in the promoters of many drought-responsive genes of Arabidopsis (Liu et al. 1998; Gilmour et al. 1999) and rice (Dubouzet et al. 2003). This offers the possibility of manipulating the regulation of plant response to multiple stresses including drought, salinity, and freezing. Preliminary evaluation of peanut, wheat, and rice transformants containing the DREB1 A gene has shown enhanced tolerance to drought stress (Dubouzet et al. 2003; Mathur et al. 2004; Pellegrineschi et al. 2004). However, expression of DREB1A gene under constitutive promoter CaMV 35s induces growth retardation under normal growth conditions (Liu et al. 1998). In contrast, plants produced using the stress-regulated rd29A promoter demonstrated increased tolerance to freezing, salt and water limited stresses, without producing changes in the normal phenotype of the transformed plants (Kasuga et al. 1999). Transgenic plants carrying coda and P5CSF: $129 \mathrm{~A}$ genes for drought tolerance in chickpea (ICRISAT 2004) and a gene for aluminium tolerance in soybean (Ermolayev et al. 2003) have also been developed that are in various stages of characterization under containment glasshouses/field trials.

Polyamines are small, ubiquitous, nitrogenous compounds that have been implicated in a variety of stress responses in plants (Bajaj et al. 1999). Plant polyamine content has been modulated by the overexpression/down-regulation of arginine decarboxylase ( $a d c$ ), ornithine decar- 
boxylase (odc), and S-adenosylmethionine decarboxylase (samdc) (Lepri et al. 2001; Mehta et al. 2002; Thu-Hang et al. 2002; Trung-Nghia et al. 2003). Overexpression of heterologous adc or odc cDNAs in plants generally results in the production of high levels of putrescine that protected the plants from environmental stresses (Capell et al. 1998). Capell et al. (2004) produced transgenic rice plants containing adc gene (maize Ubi1 promoter) from Datura stramonium that produced much higher levels of putrescine under stress, promoting spermidine and spermine synthesis. This study demonstrated that manipulation of polyamine biosynthesis in plants could produce drought-tolerant germplasm. Thus, both DREB and non-DREB genes are now available to breeders to use in enhancing the drought-tolerance profile of their legumes. However, the complex nature of this trait and the negative yield effects of many stressrelated transgenes suggests that a combination of transgenic and markerassisted selection technologies will be required to create effective new varieties. This would most likely involve the pyramiding of transgenes from outside the crop species together with drought-tolerance and yieldrelated genes from within the crop species.

Salinity Tolerance. Transgenic technologies have also been recently used to develop salt-tolerant plants by over-expressing a single gene. Glenn et al. (1999) successfully engineered transgenic Arabidopsis plants to overexpress AtNHX1, a vacuolar $\mathrm{Na}^{+} / \mathrm{H}^{+}$antiport, which allowed the plants to grow in $200 \mathrm{mM} \mathrm{NaCl}$. Meanwhile, the same genetic modification expressed in tomato plants enabled them to grow in $200 \mathrm{mM} \mathrm{NaCl} \mathrm{solu-}$ tion as well as the wild type (Zhang and Blumwald 2001). A similar strategy was also used to genetically modify rapeseed (Brassica napus), one of the most important oilseed crops cultivated worldwide (Zhang et al. 2001). The resulting plants could grow in salt concentrations that were 50 times higher than normal producing conditions. Although the transgenic plants grown in high salinity under greenhouse conditions accumulated sodium up to $6 \%$ of their dry weight, growth of these plants was only marginally affected by the high salt concentration. Moreover, the seed yields and oil quality were not affected by the high salinity of the soil. Such plants are not only tolerant to higher levels of salinity, but can also remove a high proportion of salts from soil, thus offering bioremediation of saline soils. These examples demonstrate that it should be possible in the near future to bio-engineer a broad spectrum of legume crops to be productive on saline soils or under poor water quality irrigation.

2. Increasing Symbiotic Nitrogen Fixation. Legumes have the ability to establish symbioses with rhizobia and mycorrhizal fungi, a characteris- 
tic that makes them of interest for plant nutrition research (Udvardi 2002). Caetano-Anolles and Gresshoff (1991) identified many genetic loci that are essential for symbiotic nitrogen fixation (SNF) in different legume species. Some of these genes are required for early events, such as bacterial signal recognition or events that allow colonization of the root by rhizobia. Other plant genes play essential roles in later stages of nodule development, in biochemical processes that support nitrogen fixation, and in feedback control of nodulation (Colebatch et al. 2002). Recent developments in reverse genetics and functional genomics promise to accelerate the isolation of important symbiotic genes in legumes, including the model legumes $M$. truncatula and L. japonicus. Approximately 40 symbiosis $(S y m)$ mutants have already been identified in various legume species, including pea, soybean, $M$. truncatula, and L. japonicus (Udvardi 2002) and several have been cloned by genetic and physical mapping. These Sym genes are essential for nodulation and/or symbiotic nitrogen fixation in legumes. Similarly, the discovery of a gene controlling the proliferation of induced nodule primordia in soybean (NARK) opens a new field of functional genomics of symbiosis (Gresshoff 2003).

Since increasing information and resources are becoming available from the model legumes and major crops such as pea and soybean, these resources can be harnessed for SNF research in other legumes as well. Transfer of knowledge from the model legumes to lesser-studied legume crops is a multifaceted process, which should include a systematic analysis of existing legume SNF mutants, large-scale generation and physiological characterization of new SNF mutants, and analysis of mutations focusing on known NOD and ENOD cDNAs of model legumes. Functional genomics of mutant, normal, and high-performance SNF lines could also be performed by hybridization of their nodulated and non-nodulated root cDNAs to gene chips available for the model legumes (Winter et al. 2003).

3. Biofortification. Legume crops are extremely important in human and animal diets, supplying $33 \%$ of human protein globally. Legume seeds are rich in protein, oil (peanut and soybean), minerals (iron and zinc), and vitamins. Isoflavones that are produced exclusively in legumes have drawn much attention because of their benefits to human health, and for their roles in plant defense and root nodulation. The potential to produce legume-based foods that have altered composition (both changes in nutritional properties and in anti-nutrients) is now a reality, and will further enhance the benefits from legumes in human diets.

Potential biotechnology modifications of the three major seed components of nutritional and commercial significance, namely of seed oil fatty acids, proteins, and carbohydrates, is now possible. For example, modifications of fatty acid composition, especially for high oleic acid 
content have been realised. These have been achieved through induced mutation and rDNA modifications (Downey and Taylor 1996). Soybean oil can also be changed in terms of the degree of unsaturation and the length of fatty acid chains (Topfer et al. 1995). The reduction in polyunsaturated fatty acids reduces the need for hydrogenation and thereby reduces the incidence of trans-fatty acids, which have detrimental effects on indices of coronary heart disease risk. Increasing the level of essential amino acids in oil seed meals as well as legume grains is also the subject of considerable research. For example, Kinney (1995) was able to increase the level of lysine by $7.5 \%$ to $40 \%$ of the total amino acid content of soybean and canola meals by inserting the gene cordap $A$, from Corynebacterium glucamicum, that encodes one of the enzymes insensitive to lysine feedback (dihydrodipecolinate synthase). Molving et al. (1997) introduced a chimeric gene with seed-specific expression of a sulfur-rich sunflower seed albumin into narrow-leafed lupin (Lupinus angustifolius L.). In feeding trails with rats, the transgenic seeds $(0.94 \%$ increase in methionine content and $12 \%$ reduction in cystein content) gave statistically significant increases in live weight gain, true protein digestibility, biological value, and net protein utilization compared with wild type seeds. Transgenic plants have also been developed that carry a gene encoding for a methionine-rich storage albumin protein from Brazil nut to enhance methionine in common bean and soybean (Muntz et al. 1998; Aragao et al. 1999); a gene that co-suppresses an enzyme (Grierson et al. 1996) that converts oleic acid to linoliec acid and thus improves oil quality in soybean (Mazur et al. 1999); tumor-associated, embryonic protein antibody in pea for in vitro immuno-diagnosis and in vivo imaging of human cancers (Perrin et al. 2000); and Arabidopsisbased MPBQ/MSBQ methyltransferase gene (VITAMIN E 3; VTE3) to engineer increased vitamin $E$ activity in soybean (Sattler et al. 2004). The feasibility of using genetic engineering to improve the nutritive value of grain legume has thus been demonstrated. These genes are candidates for the recently launched CGIAR global challenge program on 'Biofortified Crops for Improved Human Nutrition' (http://www.ifpri.org/ themes/grp06/paper/biofort.pdf) (also known as Harvest Plus CP), which will support research and development of nutrient-dense cultivars of 17 crops (including beans, peanut, lentil, cowpea, and pigeonpea).

4. Bioinformatics. There are many publicly available bioinformatic resources for legume researchers (Table 6.23). These include sequence repositories, gene expression databases, gene identification and structure databases, databases containing genetic and physical maps, genomic databases, metabolic pathways, protein and structure databases, and their associated tools. All of these resources have been developed by 
Table 6.23. Bioinformatic resources for legume genomics and molecular breeding.

\begin{tabular}{|c|c|c|}
\hline Database & Analysis and retrieval tool & Database content \\
\hline $\begin{array}{l}\text { TIGR Medicago Gene } \\
\text { Indices }\end{array}$ & $\begin{array}{l}\text { Blast, query pages and sequence } \\
\text { downloads }\end{array}$ & $\begin{array}{l}\text { Sequence resource permitting searches } \\
\text { based on sequence similarity, } \\
\text { keywords or tissue origin, functional } \\
\text { annotation, analysis and } \\
\text { comparisons of EST expression } \\
\text { between different libraries or tissues }\end{array}$ \\
\hline $\begin{array}{l}\text { M. truncatula } \\
\text { genomic resources }\end{array}$ & $\begin{array}{l}\text { Genscan, Diogenes for ORF finding, } \\
\text { and Blast tools }\end{array}$ & $\begin{array}{l}\text { Provides access to } M \text {. truncatula cDNA } \\
\text { and BAC libraries, chromosome } \\
\text { marker maps, protocols and links to } \\
\text { other databases like the Oybase, TAIR, } \\
\text { Gramene, Beangenes, and UKCropnet. }\end{array}$ \\
\hline $\begin{array}{l}\text { M. truncatula } \\
\text { genome database }\end{array}$ & Blast & $\begin{array}{l}\text { Integrated database containing physical } \\
\text { mapping data, genetic mapping data } \\
\text { and BAC sequence data }\end{array}$ \\
\hline $\begin{array}{l}\text { Medicago EST } \\
\text { Navigation System } \\
\text { (MENS) }\end{array}$ & $\begin{array}{l}\text { PATSCAN, BLAST, FrameD, gene } \\
\text { finding programmes, electronic } \\
\text { northerns, sequence analysis tools, } \\
\text { protein family search }\end{array}$ & $\begin{array}{l}\text { Genomic, EST, proteomic, and } \\
\text { expression data from Medicago have } \\
\text { been integrated in this database and } \\
\text { can be mined. }\end{array}$ \\
\hline $\begin{array}{l}\text { SNRF Plant 2D- } \\
\text { PAGE database for } \\
\text { Medicago } \\
\text { truncatula }\end{array}$ & Query pages & 2D PAGE gel archives. \\
\hline $\begin{array}{l}\text { Proteomics of } \\
\text { Medicago } \\
\text { truncatula }\end{array}$ & Query pages & $\begin{array}{l}\text { 2D MaldiTOF experimental data, } \\
\text { Tandem Mass spectrometry and 2D } \\
\text { electrophoresis experiments }\end{array}$ \\
\hline
\end{tabular}
http://www.tigr.org/tigr- scripts/tgi/T_index.cgi?specie $\mathrm{s}=$ medicago

http://www.medicago.org other databases like the Oybase, TAIR, tegrated database containing physical

http://mtgenome.ucdavis.edu/db/

http://medicago.toulouse.inra.fr $/ \mathrm{mt} / \mathrm{EST}$

http://www.noble.org/2Dpage/s earch.asp

http://www.mtproteomics.fr.st/ 


\section{L. japonicus \\ Genomics \\ database}

\section{TIGR Lotus Gene Indices}

TIGR soybean Gene Indices

Soybase

Soybean Gbrowse database

Soybean genomics and microarray

database
Blast, keywords search, searching the Lotus japonicus EST index through query pages, and the Legume genome Scanner

Blast, query pages and sequence downloads

Blast, query pages and sequence downloads

Blast and query pages to search EST collection and annotations

\section{Gbrowse}

Database query tools
Provides access to LegumeBase, a database containing genetic resource information from $L$. japonicus and $G$. max. Besides, EST, marker, mapping data and access to leguminous genes from Lotus and Medicago is provided.

Sequence resource, permitting searches based on sequence similarity,

keywords or tissue origin, functional annotation, analysis and comparisons of EST expression between different libraries or tissues and analysis.

Sequence resource, permitting searches based on sequence similarity,

keywords or tissue origin, functional annotation, analysis and comparisons of EST expression between different libraries or tissues.

Provides access to comprehensive genetic maps, 25 single population molecular marker maps, marker information, allele data, information on agronomic traits, pathways data, germplasm data, proteins mapped, etc.

Soybean genomics information.

Sequence and microarray experiment data. http://www.kazusa.or.jp/lotus/

http://www.tigr.org/tigrscripts/tgi/T_index.cgi?specie $\mathrm{s}=1$ _japonicus

http://www.tigr.org/tigrscripts/tgi/T_index.cgi?specie $\mathrm{s}=$ soybean

http://soybase.org

http://bioinformatics.siu.edu/

http://psi081.ba.ars.usda.gov/S GMD/Default.htm 
Table 6.23. (continued)

\begin{tabular}{|c|c|c|c|}
\hline Database & Analysis and retrieval tool & Database content & URL \\
\hline $\begin{array}{l}\text { Soybase Pathways } \\
\text { Database }\end{array}$ & $\begin{array}{l}\text { Metabolic component of soybase, con- } \\
\text { tains diagrams for viewing pathways }\end{array}$ & $\begin{array}{l}\text { Metabolic pathways, descriptions, and } \\
\text { diagrams for basic pathways. }\end{array}$ & $\begin{array}{l}\text { http://soybase.ncgr.org/cgi-bin/ } \\
\text { ace/generic/search/soybase }\end{array}$ \\
\hline $\begin{array}{l}\text { Legume Information } \\
\text { system (LIS) }\end{array}$ & Blast LIS & $\begin{array}{l}\text { EST, genomic, map, pathway, proteo- } \\
\text { mic resources from multiple legume } \\
\text { species, enabling cross species } \\
\text { comparisons. }\end{array}$ & $\begin{array}{l}\text { http://www.comparative- } \\
\text { legumes.org/ }\end{array}$ \\
\hline Legume DB & $\begin{array}{l}\text { Blast, Fasta, Fastacmd, Repeat Masker, } \\
\text { ClustalW, EMBOSS tools, Xcompare, } \\
\text { MultiBlast, CMAP and BioDAS map } \\
\text { visualization tools }\end{array}$ & $\begin{array}{l}\text { Permits comparative genomics, candidate } \\
\text { gene mining, PCR primer design. Map } \\
\text { visualization tools allow highlighting } \\
\text { of areas of macro and micro synteny } \\
\text { across closely related target species. }\end{array}$ & $\begin{array}{l}\text { http://cbbc.murdoch.edu.au/ } \\
\text { projects/legumedb/ }\end{array}$ \\
\hline $\begin{array}{l}\text { ILDIS-International } \\
\text { legume database } \\
\text { and Information } \\
\text { service }\end{array}$ & $\begin{array}{l}\text { Web based query tool-LegumeWeb and } \\
\text { litchi software }\end{array}$ & $\begin{array}{l}\text { Permits searching of the world's legume } \\
\text { species diversity catalog. The litchi } \\
\text { software enables merging of taxono- } \\
\text { mic data from different sources. }\end{array}$ & http://www.ildis.org/ \\
\hline $\begin{array}{l}\text { Consensus Legume } \\
\text { DB }\end{array}$ & $\begin{array}{l}\text { Provides links to several databases and } \\
\text { their associated sequence analysis } \\
\text { and mapping tools. }\end{array}$ & $\begin{array}{l}\text { Integrates EST, unigene, HTGS, } \\
\text { markers, maps, etc. from multiple } \\
\text { sources: the M. truncatula } \\
\text { consortium DB, TIGR resources, } \\
\text { Soybase, Arabidopsis Information } \\
\text { resource (TAIR) and Gramene. }\end{array}$ & http://www.legumes.org \\
\hline $\begin{array}{l}\text { KEGG pathways } \\
\text { Database }\end{array}$ & Query pages, visualization tools & Information on metabolic pathways. & $\begin{array}{l}\text { http://www.genome.jp/kegg/ } \\
\text { metabolism.html }\end{array}$ \\
\hline Sputnik & Query interface & $\begin{array}{l}\text { Functional predictions, comparative } \\
\text { analysis and annotation for 500,000 } \\
\text { plant EST derived peptides. }\end{array}$ & http://sputnik.btk.fi/ \\
\hline
\end{tabular}


researchers focusing on M. truncatula, L. japonicus, and G. max. However, the information is valuable for comparison and extrapolation to other legumes. There are also increased efforts toward providing a single portal/or consensus database with links to individual crop-specific databases to provide a single platform for the comparative genomics of legumes. Most databases provide access to several bioinformatic tools, comparative mapping, and data visualization tools. These include sequence comparison methods such as various versions of BLAST, gene prediction tools, pattern searching and mapping programs, etc. Databases generated specifically for legume researchers are more eclectic, combining varieties of tools for the analysis of several types of datasequence, proteomic, or expression data (such as the MENS database). Since data analysis methods are dynamic, varying with the nature of data and hypothesis tested, database systems are now being designed that insulate the analysis methods from the data itself. One such system is DOME (http://medicago.vbi.vt.edu/index.html), a relational database that allows merging of microarray, proteomic, and metabolic profile data in Medicago. While these represent a new generation of databases, still the most frequently used resources are those individual model legume repositories such as the TIGR Gene Indices. These databases are curated, containing the results and analysis of worldwide projects on the target species; the data is non-redundant and annotated. Information on gene expression and protein family is also available and retrievable, making this a highly useful resource for legume research.

The molecular maps for legume crops of the semi-arid tropics (cowpea, groundnut, and pigeonpea) are not very dense compared to the other related legume crops such as soybean, common bean, and pea. However, data from related species could be mined to develop maps and markers. Hence, nucleotide sequences of the legume model species $M$. truncatula, available at the National Center for Biotechnology Information (http://www.ncbi.nlm.nih.gov), have been downloaded in FASTA format and the repeat patterns in the sequence were located using the tandem repeat finder program at http://c3.biomath.mssm.edu/trf.html (Mahalakshmi et al. 2002). The sequences with potential repeat motifs were then analysed to determine possible potential flanking regions around the repeat motifs, which might yield product sizes of about 200 bp using the PRIMER 3 program (http://www-genome.wi.mit.edu/cgibin/primer/primer3_www.cgi). The gene indices database from TIGR (http://www.tigr.org/tdb/tgi/mtgi/) was also downloaded, and a local database containing the entire sequences in FASTA format, the repeat motif, the potential primer, and the gene indices was created in a relational database (SQL7.0 ${ }^{\mathrm{TM}}$ ). The resultant database of repeat motifs was 
analyzed to classify the patterns, and their occurrence and abundance (Mahalakshmi et al., submitted). Of about 156,000 sequences that were searched, 7325 sequences were found to contain a repeat motif and may yield SSRs with amplification product sizes of around $200 \mathrm{bp}$. Of these, the most abundant repeats were the tri-nucleotide (5210) group. Except for a very small proportion (436), these link to the gene annotation database at TIGR. To facilitate further exploration of this resource, a dynamic database with options to search and link to other resources is being developed. Such an approach may lead to the development of microsatellite markers for the same species or closely associated species within the same genus.

Modern comparative and functional genomics coupled with new marker technologies as well as bioinformatic, biometric, and modeling tools are becoming a major force for an emerging revolution in crop improvement that seeks to identify and define the structure and function of key genes, and reveal when and how these genes generate desirable phenotypes that can be used in crop improvement. Combining this knowledge with recent advances in genomics technologies provides the mechanism for "Breeding by Design" (Peleman and van der Voort 2003) where new varieties and new crop products can be designed in a more rational way than has been previously possible through conventional plant breeding. Having documented here the progress in studying and manipulating key individual traits, we are now poised for a new paradigm in plant breeding in which entire profiles of specifically selected genes can be manipulated to provide a complement of desirable traits. High-value crop ideotypes will be sequentially generated combining target product profiles for any specific cropping system environment. These "designer legumes" will transform and merge agricultural and industrial production to an extent only limited by mankind's imagination and motivation to continue to innovate.

\section{ADVANCED APPLICATIONS IN LEGUME MOLECULAR BREEDING}

\section{A. Comparative Genomics and Allele Mining}

In this section, we describe the comparative genomic relationships between model species, major crops, and lesser-studied but economically important legume crops. In particular, we focus on the potential of comparative mapping and gene sequence homology to benefit structural and functional genomics, and ultimately molecular breeding of 
legume crops. In this context, we consider structural genomics the construction of genetic and physical maps, and functional genomics the comparison of gene expression across tissues, species, and environments. Both of these fields are being fueled by rapid access to new genetic and sequence information, and are driving the important area of comparative biology.

1. Model Systems. As discussed in the introduction, two model legumes, L. japonicus and M. truncatula, have been studied intensively with a particular initial emphasis on symbiotic relationships with nitrogen-fixing rhizobia and arbuscular mycorrhizal fungi as well as the synthesis of secondary metabolites such as isoflavonoids that are not found in $A$. thaliana (Barker et al. 1990; Handberg and Stougaard 1992; Jiang and Greshoff 1997; Cook et al. 1997). Along with A. thaliana, these species have emerged as the genomic hubs for comparative mapping and genomic studies in the dicots. The key attributes of all model plants are a small diploid genome, rapid reproductive cycle, autogamous nature, prolific seed production, and numerous genetic and genomic resources available for the molecular investigation of diverse traits of biological and economic importance (Table 6.24). M. truncatula is a forage legume commonly grown in Australia and is a close relative of lucern (alfalfa: M. sativa), the most important forage crop worldwide. In addition, it belongs to the same phylogenetic group (galegoid) as Pisum (pea), Vicia (vetch, broadbean, and cowpea), Cicer (chickpea), Lens (lentil), and Trifolium (clover) (Doyle et al. 1996). The M. truncatula genome is organized into two distinct regions: the pericentromeric heterochromatin, which is rich in repeated sequences but contains a low density of expressed genes and the extensive gene-rich euchromatic regions. Gene density is approximately one gene per 6-10 kilobase pairs (kbp) in $M$. truncatula, on par with that of $A$. thaliana (Nakamura et al. 2002; Young et al. 2003). In contrast, $L$. japonicus is phylogenetically distant from the galegoid phylum and less closely related to most economically important legumes except for groundnut and Lupin. Both model legumes are distant from the Phaseoleae tribe that includes many important legumes such as soybean (Glycine), common bean (Phaseolus), and pigeonpea (Cajanus). Researchers have made substantial progress toward creating numerous genetic and genomics resources in the two model legumes: $M$. truncatula has a dense genetic linkage map (Thoquet et al. 2002), numerous mutants (Sagan et al. 1995; Penmetsa and Cook 1997), tissue specific cDNA libraries (Gamas et al. 1996; Covitz et al. 1998; Gyorgyey et al. 2000), EST collections (Journet et al. 2002), isolated resistant gene analogues (Cannon et al. 2002; Zhu et al. 2002), large-insert BAC libraries 
Table 6.24. Key attributes of the legume model systems Medicago truncatula and Lotus japonicus compared with Arabidopsis thaliana.

\begin{tabular}{|c|c|c|c|}
\hline Key attributes & Medicago truncatula & Lotus japonicus & Arabidopsis thaliana \\
\hline $\begin{array}{l}\text { Ploidy level/ } \\
\text { chromosome \# (n) }\end{array}$ & Diploid, $\mathrm{n}=8$ & Diploid, $\mathrm{n}=6$ & Diploid, $\mathrm{n}=5$ \\
\hline $\begin{array}{l}\text { Genome size and } \\
\text { sequencing } \\
\text { information }\end{array}$ & $\begin{array}{l}500-550 \mathrm{Mbp} \text {; sequencing of the } \\
\text { entire gene space ongoing }\end{array}$ & $\begin{array}{l}400 \mathrm{Mbp} \text {; large-scale genome sequencing } \\
\text { initiated }\end{array}$ & $\begin{array}{l}120 \mathrm{Mbp} \text {; entire genome } \\
\text { sequenced }\end{array}$ \\
\hline Breeding behavior & Self fertile and short generation time & Self fertile and short generation time & $\begin{array}{l}\text { Self fertile and short } \\
\text { generation time }\end{array}$ \\
\hline Reproduction & Prolific seed production & Prolific seed production & Prolific seed production \\
\hline DNA markers & $\begin{array}{l}\text { PCR (RAPD, AFLP, SSRs, and ESTs)- } \\
\text { based markers reported (Cho et al. } \\
\text { 1999; Drenakrd et al. 2000; Jander } \\
\text { et al. 2002; Torjeck et al. 2003; } \\
\text { Schmid et al. 2003) }\end{array}$ & $\begin{array}{l}\text { PCR-based markers (RAPD, AFLP, SSRs, and } \\
\text { ESTs) reported (Covitz et al. 1998; White } \\
\text { et al. 2000; Baquerizo-Audiot et al. 2001; } \\
\text { Fedorova et al. 2002; Journet et al. 2002; } \\
\text { www.medicago.org) }\end{array}$ & $\begin{array}{l}\text { Both RFLP and PCR (RAPD, } \\
\text { AFLP, SSRs, ESTs, and } \\
\text { SNPs)-based markers } \\
\text { reported (Asamizu et al. } \\
\text { 2000; Poulsen and } \\
\text { Podenphant 2002) }\end{array}$ \\
\hline Genetic linkage map & $\begin{array}{l}\text { A genetic linkage map with an } \\
\text { average map density of } 4.24 \mathrm{cM} \\
\text { reported (Chang et al. 1988, 2001; } \\
\text { Nam et al. 1989; Reiter et al. 1992; } \\
\text { Lieu et al. 1996; Choi et al. 2004) }\end{array}$ & $\begin{array}{l}\text { A high density genetic map with an average } \\
\text { map distance of 0.6 cM reported (Kulikova } \\
\text { et al. 2001; Thouquet et al. 2002; Sandal et } \\
\text { al. 2002; Hayashi et al. 2001); Chromo- } \\
\text { some map integrating the position of BAC } \\
\text { and plasmid clones from } 32 \text { genomic } \\
\text { regions (Pedrosa et al. 2002) }\end{array}$ & $\begin{array}{l}\text { Genetic maps with average } \\
\text { map density between } \\
1.88 \text { to } 5.24 \text { cM are } \\
\text { reported (Jiang and Gress- } \\
\text { hoff 1997; Sandal et al. } \\
\text { 2002; Pedrosa et al. 2002; } \\
\text { Fjellstrom et al. 2003) }\end{array}$ \\
\hline
\end{tabular}


Genome sequencing

Genetic

transformation

\section{Symbiotic} relationship

Genetic and genomic resources
111 Mbp of the 454-526 Mbp genome sequenced; 190,000 ESTs submitted to Genbank of which about 37,000 are Unigenes http://www.medicago .org/genome/stats.php

Efficient transformation protocol established

Symbiotic relationships with Sinorhizobium and mycorrhizae; a model legume to study indeterminate nodulation

BAC clones; large ESTs; FISH for analysis pachytene chromosome and gene TILLING to identify point mutation; efficient transformation system; high density genetic map; numerous ecotypes and RILs; high degree of synteny with diploid alfalfa and pea
A total of 320 TAC clones covering $32.5 \mathrm{Mb}$ sequenced (Sato et al. 2001; Nakamura et al. 2002; Kaneko et al. 2003; Asamizu et al. 2003; Kato et al. 2003)

Efficient transformation protocol established

Symbiotic relationships with Rhizobium and mycorrhizae; a model legume to study determinate nodulation

Linkage maps, BAC library (Men et al. 2001); expression arrays both for plant and endosymbiont genes; efficient transformation system; cDNA libraries constructed and large number of ESTs developed; gene TILLING to identify point mutations; genome sequencing initiated; tools for rapid map-based cloning of genes; diverse ecotypes and mutants and RILs (Gifu B-129 × Miyakojima MG-20)
115.4 Mb of the $125 \mathrm{Mb}$ genome sequenced (AGI 2000)

Efficient transformation protocol established

No symbiotic relationships either with Rhizobium or with mycorrhizae

BAC/BIBAC library; large numbers of RFLP, RAPD, AFLP, SSRs, ESTs, and SNPs; efficient

transformation system; high density of genetic map; numerous ecotypes and RILs 
(Nam et al. 1999), an efficient transformation system (Chabaud et al. 1996; Trinh et al. 1998; Trieu et al. 2000), and a well-characterized nitrogen-fixing symbiont, Sinorhizobium meliloti (Galibert et al. 2001). A database of over 170,000 M. truncatula (Mt) ESTs has been assembled based on in-depth sampling from various developmental stages and pathogen-challenged tissues (http://www.medicago.org/MtDB) and can be queried through a series of interfaces and filters. A relational database provides a wide range of user-defined data mining options, allowing researchers to quickly and independently identify sequences that match specific research interests through user-defined criteria (Lamblin et al. 2003). The $L$. japonicus genomic resources include diverse ecotypes, a large number of DNA markers, a high-density genetic linkage map, expression arrays, cDNA and BAC libraries, a partially sequenced genome (320 TAC clones covering $32.5 \mathrm{Mb}$ ), an efficient transformation protocol, and well-studied symbiotic relationships with Rhizobium and Mycorrhizae (Table 6.24).

\section{Comparative Mapping}

Synteny between Dicot Families. Comparative genomics is defined as the study of similarities and differences in the structure and function of gene(s) across taxa (Paterson et al. 2000). It facilitates the mapping of orthologous loci across plant species, genera, and families. Orthologous loci show common vertical descent and function as opposed to paralogs that are genes that have arisen within the same genome through duplication and may have evolved different functions (Fitch 1970). Comparative mapping in monocots has demonstrated that the order and sequence of genes is highly conserved between different cereal crop genomes (Devos and Gale 1997; Gale and Davos 1998). More recently, nearly six thousand Triticaea ESTs that had been physically mapped using wheat (Triticum aestivum L.) deletion lines and segregating populations were compared with the first draft of the public rice genome sequence. A rice genome perspective on the homoeologous wheat genome based on sequence analysis shows general similarity to the previously published comparative maps based on RFLP analysis. For most rice chromosomes, there is a preponderance of wheat genes. However, some wheat ESTs with multiple wheat genome locations is associated with genomic regions not well conserved between rice and wheat. Conversely, comparing the wheat deletion map with the rice genome sequence revealed a breakdown of gene content and order synteny. This suggests there is an abundance of rearrangements, insertions, and duplications that differentiate the wheat and rice genomes. These differences may complicate the use of rice as a hub for cross-species transfer of infor- 
mation in non-conserved regions (La Rota and Sorrells 2004). Comparative mapping amongst dicots has revealed an even a more complex pattern but comparative genomics still offers a range of important potential impacts (Bennetzen 2000; Paterson et al. 2000). Initial comparative mapping in the Solanaceae family (like that in cereals) was based on restriction fragment length polymorphism (RFLP) analysis. More recently, a large number of conserved ortholog sequence (COS) markers have also been identified for comparative genomics between Arabidopsis and members of the Solanaceae (Fulton et al. 2002). COS markers can be used directly as hybridization probes in RFLP mapping or, alternatively, the COS sequences can be used to BLAST search EST databases or to design PCR markers to amplify the orthologous locus in the target species. Significant synteny between Arabidopsis and soybean has been demonstrated along the entire length of Arabidopsis chromosome 1 and soybean linkage group A2 (Grant et al. 2000). There are also several examples of synteny mapping between Arabidopsis and the model legume species (Table 6.24).

Synteny amongst Legumes. The phylogenetic relationships between different legume genera suggests that a comparative genomics approach will be useful in translating knowledge and tools from the model legumes to other legume species within the Papilionoideae subfamily. Legumes are seen to form a coherent taxonomic group with frequent and widespread macro- and micro-synteny (Young et al. 2003), as evidenced by an increasing number of studies showing the relationships between Medicago/Lotus and various grain legume crops (Table 6.25) and between different food legumes (Table 6.26).

There are a number of reports concerning the cross species and genera amplification of SSR markers. Eujayl et al. (2004) demonstrated that a high proportion of $M$. truncatula ESTs-based SSRs markers amplified in species throughout the Medicago genus. Similarly, a high proportion of SSR markers from pea amplified in vetch (39\%) and lentil (60-75\%), although a lower proportion of chickpea SSR markers amplified in pea (18\%) (Pandian et al. 2000). However, Peakall et al. (1998) reported limited cross-genera SSR amplification (3\% to 13\%) within the Papilionoideae, although cross species amplification was more successful. More recently, the transferability of SSR markers between Medicago, soybean, cowpea, and peanut revealed a high proportion $(30.78 \%)$ of the SSR primers generating reproducible and cross-genus amplicons (117 polymorphic bands) that could be used as DNA markers for characterization and evaluation of legume germplasm (Wang et al. 2004a). Twentythree universal primers [SNP-containing sequence tagged sites (STS)] in soybean, common bean, cowpea, chickpea, and barrel medic are reported 
Table 6.25. Examples of comparative mapping between dicot model systems (Arabidopsis, Medicago or Lotus) and legume crops (chickpea, pea and soybean).

Plant species

Comparative mapping result

Reference

Arabidopsis and chickpea

Arabidopsis and soybean

Arabidopsis, Lotus, and pea

Arabidopsis, Medicago, and soybean

Medicago and pea

Medicago, Lotus, and soybean
Synteny between the Fusarium resistance gene cluster of chickpea (19 markers on linkage group 2) and the corresponding regions in the Arabidopsis genome (short segments of chromosome 1 and 5).

Mapping of 82 tentative orthologous genes reveals a lack of extended macrosynteny between the two genomes, although localized synteny has been frequently reported over small genetic intervals. The genetically linked loci in M. truncatula often share multiple points of synteny with Arabidopsis. The two genomes are related by network of microsynteny that is often highly degenerate either due to selective gene loss from duplicated loci or due to the absence of close homologs of $M$. truncatula genes in Arabidopsis.

27 of 78 sequences on soybean molecular linkage group (MLG)-G showed significant similarity to Arabidopsis. The conserved microsynteny in Bng122-Bng173 region of soybean with Arabidopsis extends over several hundred kbp.

Soybean linkage group A2 (soyA2) and Arabidopsis chromosome 1 showed significant synteny over almost their entire lengths, with only $2-3$ chromosomal rearrangements required to bring the map into substantial agreement. Smaller blocks of synteny were identified between soyA2 and Arabidopsis chromosome 4 and 5 (near the RPP5 and RPP 8 genes) and between soyA2 and Arabidopsis chromosomes 1 and 5 (near the PhyA and PhyC genes).

LjSYM2 gene from L. japonicus and PSSYM19 from P. sativum are required for the formation of nitrogenfixing root nodules and arbuscular mycorrhiza. Local colinearity in the region around LjSYM2/PsSYM19 identified in all the three species; LjSYM2/PSSYM19 corresponds to two duplicated segments of the Arabidopsis chromosomes AtII and AtIV.

27 of the 50 soybean contig groups showed microsynteny with Medicago. Substantial conservation among soybean contigs in the same group, with $86.5 \%$ of the groups showing at least some level of microsynteny. Seven of the 50 soybean contig groups (14\%) exhibited microsynteny with Arabidopsis.

$M$. truncatula and pea genomes at SYM2 region share a conserved gene content.

Apyrases are suggested to play important roles in plant nutrition, photomorphogenesis, and nodulation. A phylogenetic analysis of apyrase homologs from M. truncatula, Glycine max, and Lotus japonicus identified a potentially legume-specific clade that contains a well-characterized soybean (Glycine soja) apyrase, Gs52, as well as homologs from Dolichos, Lotus, Medicago, and Pisum. Sister clades contain homologs from members of Brassicaceae, Solanaceae, Poaceae, and Fabaceae.
Benko-Iseppon et al. 2003

Zhu et al.

$2003 \mathrm{~b}$

Foster-

Hartnett et

al. 2002

Grant et al. 2000

Stracke et al 2004

Yan et al. 2003

Gualtieri et al. 2002

Cannon et al. 2003 
Table 6.26. Examples of comparative mapping amongst tropical and temperate grain legumes, 1992 to 2002.

\begin{tabular}{|c|c|c|}
\hline Plant species & Level of synteny & Reference \\
\hline $\begin{array}{l}\text { Azuki bean and } \\
\text { rice bean }\end{array}$ & $\begin{array}{l}\text { Comparison between two adzuki interspecific maps, the UA linkage map ( } V \text {. umbellata } \times V \text {. angularis }) \\
\text { and the AN map ( } V \text {. angularis } \times V \text {. nakashimae), revealed that UA linkage groups } 1,3,4,6,7,10 \text {, and } \\
11 \text { correspond to AN linkage groups } 4,3,6,1,5,7 \text {, and } 11 \text {, respectively. Sixteen conserved linkage } \\
\text { blocks were found in the interspecifc map of } V \text {. angularis } \times V \text {. nakashimae and } V \text {. radiata. }\end{array}$ & $\begin{array}{l}\text { Kaga et al. } \\
\quad 2000\end{array}$ \\
\hline \multirow[t]{2}{*}{$\begin{array}{r}\text { Cowpea and } \\
\text { mungbean }\end{array}$} & $\begin{array}{l}\text { Genomic regions in linkage group } 2 \text { with greatest effect on seed weight spanned the same RFLP markers } \\
\text { that are collinear in arrangement on homologous linkage groups both in cowpea and mungbean. }\end{array}$ & $\begin{array}{l}\text { Fatokun et al. } \\
1993\end{array}$ \\
\hline & $\begin{array}{l}\text { The hybridization analysis revealed that the genic complement between mungbean and cowpea appears } \\
\text { to be similar at the nucleotide level, although the copy number of some loci changed between them. } \\
\text { The comparative map demonstrated that some linkage blocks remained highly conserved in both the } \\
\text { species but that the linear arrangement of the markers has changed. Other linkage groups in cowpea } \\
\text { consists of segments from different linkage blocks in mungbean. }\end{array}$ & $\begin{array}{l}\text { Menancio- } \\
\text { Hautea et al. } \\
1993\end{array}$ \\
\hline $\begin{array}{l}\text { Mungbean, } \\
\text { common } \\
\text { bean, and } \\
\text { soybean }\end{array}$ & $\begin{array}{l}\text { Mungbean and common bean exhibited a high degree of linkage conservation and preservation of marker } \\
\text { order. On average, the length of conserved genetic blocks between these species is approximately } 36.6 \\
\mathrm{cM} \text { and the longest is } 103.5 \mathrm{cM} \text {. Only short and scattered linkage blocks are conserved between mung- } \\
\text { bean or common bean and soybean, with an average length of } 12.2 \mathrm{cM} \text { for conserved blocks between } \\
\text { mungbean and soybean and } 13.9 \mathrm{cM} \text { for the conserved block between common bean and soybean. }\end{array}$ & $\begin{array}{l}\text { Boutin et al. } \\
1995\end{array}$ \\
\hline $\begin{array}{l}\text { Cowpea, mung- } \\
\text { bean, and } \\
\text { soybean }\end{array}$ & $\begin{array}{l}\text { Soybean and cowpea share an orthologous seed-weight gene, and the genomic region significantly associ- } \\
\text { ated with seed weight spanned the same RFLP markers (sgA816, sgK024, and sgA226) in the same } \\
\text { linkage order, but not in mungbean. However, the linear order of these marker loci is conserved in all } \\
\text { the three species. }\end{array}$ & $\begin{array}{l}\text { Maughan et al. } \\
1996\end{array}$ \\
\hline $\begin{array}{l}\text { Mungbean and } \\
\text { lablab }\end{array}$ & $\begin{array}{l}\text { Comparison of mungbean and lablab genetic linkage map, using common } 65 \text { RFLP probes, reveals highly } \\
\text { conserved marker order between the two genomes. However, the two genomes have apparently accumu- } \\
\text { lated a large number of duplicates/deletions after they diverged. }\end{array}$ & $\begin{array}{l}\text { Humphry et } \\
\text { al. } 2002\end{array}$ \\
\hline Pea and lentil & $\begin{array}{l}\text { Conserved linkage relationships exist for } 250 \mathrm{cM} \text { regions on linkage groups } 1,2,4,5 \text {, and } 6 \text { between lentil } \\
\text { and pea genetic map. }\end{array}$ & $\begin{array}{l}\text { Weeden et al. } \\
1992\end{array}$ \\
\hline $\begin{array}{l}\text { Pea, chickpea, } \\
\text { and lentil }\end{array}$ & $\begin{array}{l}\text { Five regions of the chickpea map have gene orders similar to those found in the pea genome. However, } \\
\text { the degree of similarity is somewhat less than that found between pea and lentil. }\end{array}$ & $\begin{array}{l}\text { Simon and } \\
\text { Muehlbauer } \\
1997\end{array}$ \\
\hline $\begin{array}{l}\text { Pea, lentil, and } \\
\text { broadbean }\end{array}$ & $\begin{array}{l}\text { One of the } 11 \text { linkage groups in broadbean contains two isozyme loci, EST and Tpi-p, which share some homol- } \\
\text { ogy with chromosome } 4 \text { of pea. Another isozyme loci, Prx-1, is conserved in pea, broadbean, and lentil. }\end{array}$ & $\begin{array}{l}\text { Torres et al. } \\
1993\end{array}$ \\
\hline
\end{tabular}


when screening 1204 soybean-derived STS (http://www.embrapa.br/ labex/download/perry-cregan-group-poster.pdf). Similarly, a comparison of sequenced regions in M. truncatula, L. japonicus, and G. max revealed high conservation between the genomes of $M$. truncatula and $L$. japonicus but a lower level of conservation between M. truncatula and G. max. This suggests that comparative mapping may have considerable utility for basic and applied research in the legumes, although its predictive value is likely to decline with increasing phylogenetic distance and genome duplication (Choi et al. 2004a). Thus, an ongoing collaboration of Aarhus University (Denmark) with EMBRAPA and UCB (Brazil) is integrating Arachis into a single unified legume genetic framework using "legume family anchor markers." This project has identified 867 evolutionary conserved sequences (ECSs) from M. truncatula, G. max, and $L$. japonicus that have a high probability of being conserved in less well-characterized legumes. The comparison of map positions of ECS markers in different legumes should allow the development of a preliminary comparative map across an extensive range of legume crops and model systems (David Bertioli, EMBRAPA, unpublished data).

\section{International Initiatives Harnessing Comparative Genomics for Crop}

Improvement. The revolution in biology, data management, and communications has provided the scientific communities with tremendous opportunities for solving some of the world's most serious agricultural and food security issues. This has led to the formation of the Generation Challenge Program (GCP) "Unlocking Genetic Diversity in Crops for the Resource-Poor" (www.generationcp.org). Generation Challenge Program (GCP) is based on harnessing comparative biology to release the value of global germplasm collections through the development of improved molecular breeding systems with a particular focus on drought tolerance. The development of gene-based markers in cereals, legumes, and clonal crops through comparative analysis with the model systems is a key component of this program. The GCP is creating a strong coalition of institutions dedicated to alleviating poverty through the application of recent advances in biological sciences. This alliance aims to harness powerful tools of the genomics revolution to unlock the genetic potential within crop germplasm to address the needs of the resource-poor in developing countries. The key feature of the platform is the creation of a platform that is applicable to any crop and any trait. Preliminary proofof-concept activities focus on the 22 mandate crops of the CGIAR (Consultative Group on International Agricultural Research) system and environmental stress tolerance traits. The development goal of this challenge program is to increase food security and improve livelihoods in 
developing countries by enhancing the use of freely available genetic resources in plant breeding programs. This requires a concerted focus on the generation, management, dissemination, and application of comparative biological knowledge. The GCP contributes to this goal by creating an integrated platform for dissecting genetic diversity in crop plant genetic resources by identifying important genes to reduce the impacts of environmental stresses on crop productivity. Complementary efforts will also be captured to enhancing yield through improved pest and disease resistancee and improve nutritional quality of crop products. Beyond this, the challenge program will identify, manipulate, and validate gene expression, resulting in plants with potential value far beyond the present-day crops. New traits (and the tools to manipulate them) will be transferred, through seeds or vegetative propagules, to breeding programs across the developing world. The challenge program is divided into five subprograms-genetic diversity of global genetic resources; comparative genomics for gene discovery; trait capture for crop improvement; genetic resource, genomic, and crop information systems; and capacity-building and product delivery.

Medicago Genomics Consortium. The Center for Medicago Genomics Research, established at the Samuel Roberts Noble Foundation, USA (http://www.noble.org/medicago/index.htm), is engaged in the study of genetic and biological events associated with growth, development, and environmental interactions in $M$. truncatula using large-scale EST sequencing, gene expression profiling, and high throughput metabolite and protein profiling. The center is interfacing these multiple technologies to produce an integrated set of tools that can address fundamental questions about (a) biosynthesis of natural products affecting forage quality and human health, (b) cellular and molecular basis for the gravitropic root growth and the role of cytoskeleton in this process, (c) legume root development and molecular mechanisms of polar auxin transport, (d) non-host pathogen resistance, (e) RNA silencing pathway, and (f) arbuscular mycorrhizal (AM) symbiosis. Other global genomics projects in $M$. truncatula include an inventory of gene function; BACbased sequencing of gene-rich euchromatic regions; application of bioinformatic tools to functional genomics; high-throughput TILLING (targetting induced local lesions in genome) mutant analysis; meristem proteomics; molecular interactions between rhizobium, phytohormones, and nodulation mutants; and R gene isolation and defense gene expression profiling (VandenBosch and Stacey 2003).

Lotus Genomics Consortium. The Miyakogusa foundation, a nonprofit organization in Japan, initiated research on L. japonicus in 1999 and 
develops public resources such as linkage maps, expression arrays (of both plant and endosymbiont genes), and transformation techniques. The consortium brings together 30 laboratories spread throughout Japan. A seed center has also been established at the National Agricultural Research Center, Hokkaido (http://cryo.naro.affrc.go.jp/sakumoto/mameka/lotus-e.htm) and a large set of ESTs from normalized and size-selected cDNA libraries, obtained from seven different organs, is available from the Kazuza Institute (http://www.kazusa.or.jp/en/plant/lotus/est).

Soybean Genomics Consortium. Soybean is a major source of edible oil and high-quality protein, and a leading commercial crop in the United States, where soybean commodity boards (notably the North Central Soybean Research Program and United Soybean Board) have supported genomics as a way of encouraging genetic enhancement in the crop through the development of DNA markers, transformation techniques, structural and functional genomics, as well as bioinformatics. Soybean has a complex genome structure but a rich repertoire of genomic tools and resources that include a vast EST collection (more than 300,000 ESTs from approximately $80 \mathrm{cDNA}$ libraries mostly from the cultivars Williams and Williams 82) and 400 SNP markers developed from ESTs, a densely populated genetic map (over 1000 SSRs and 700 RFLP markers on a consensus map), a developing physical map (consisting of 3,000 contigs anchored to about 500 genetic markers), microarray resources, and an efficient transformation system. The array of resources available would be improved by finishing the physical map and by developing a better understanding of the gene space and chromosomal topography of the species (Shoemaker et al. 2003; http://www.agbioforum.org; http:// www.soybeangenome.org/soybeansIntlminutes.html). The successful application of biotechnology-assisted breeding of soybean is expected to provide considerable direct and indirect support for similar progress in other legume crops.

Common Bean Consortium. Common bean genomics scientists formed a consortium to establish the necessary framework of knowledge, resources, and tools required to generate disease-resistant, stresstolerant, high-quality, and high-yielding common bean varieties (http:// www.phaseolus.net/phaseomics; Broughton et al. 2003).

Chickpea Genomics Consortium. This consortium was formed in early 2003 to produce a consensus genetic linkage map of the Cicer genome, to make bacterial artificial chromosome (BAC) libraries of chickpea, and to establish a chickpea consortium website. A consensus map for Cicer arietinum and Cicer species is planned as one of the first products 
of the consortium followed by physical mapping and sequencing of important regions of the chickpea genome (http://www.icgc.wsu.edu).

Pea Microsatellite Consortium. This consortium, led by AgroGene, has 21 members worldwide, has cloned 882 sequences and designed 318 primer pairs, for the detection of polymorphism in leading pea genotypes (http://www.agrogene.com/ssrdevelopment.htm).

4. Genome Sequencing in Legumes. Genome sequencing has begun in L. japonicus (450 Mb) and M. truncatula (525 Mb) and is the basis for comparisons to the completed sequences for Arabidopsis (128 Mb) and rice (425 Mb) (indica and japonica subspecies), which has facilitated the assignment of putative functions of thousands of genes. The Medicago genome sequencing efforts also include a physical map and over 170,000 ESTs. Common bean and cowpea have small genomes, chickpea and pigeonpea have relatively large genomes, and soybean, peanut, pea, lentil, and broad bean have large to massive and complex genomes (Bennett and Leitch 2003; see also section I D). Hence, there is little likelihood in the immediate future of genome-wide sequencing projects in other legume crops. Thus, legume scientists and breeders must devise strategies to make maximum use of the complete genome sequence of Arabidopsis and the partial genome sequences of Medicago and Lotus. The development of tissue and stress-specific subtractive EST libraries in legume crops is likely to be a highly efficient means of capturing advances from model systems for these lesser-studied crops.

5. Allele Mining. Sequence information and DNA markers form the foundation of genetic linkage mapping and marker-assisted breeding, while also providing a tool for the comparison of genomes between species and for allele mining of germplasm collections. Linked SSR and AFLP markers are currently the most abundant type of mapped marker in most legume crops; however, they are not always appropriate for gene mining due to recombination between these neutral markers and the gene of interest. For this reason, the use of gene-based markers (developed from ESTs) provides a more direct path for the identification of new allelic variation from germplasm collections and a quick and inexpensive route to a short list of germplasm accessions with potentially new traits compared to phenotypic screening. Fortunately, a wealth of EST information exists in soybeans, Medicago, and several other legumes. To be useful, gene-based markers derived from ESTs need to be associated with traits, a process called candidate gene discovery. Thereafter, the new candidate gene alleles must be evaluated to determine which ones actually provide 
a beneficial effect on the trait of interest under field conditions. Associating allelic polymorphisms with phenotypic variation is confounded in plants by population structure (Buckler and Thornsberry 2002). The presence of subgroups with an unequal distribution of alleles can lead to spurious associations. This problem can be corrected by estimating population structure and by conducting appropriate association tests. This approach has been effectively used for the identification of candidate gene-based markers through association mapping of flowering time in maize (Thornsberry et al. 2001).

Mining for R-gene Alleles. The candidate gene approach has been particularly useful for the investigation of pest and disease resistance. A large group of plant resistance genes encode cytoplasmic receptor-like proteins that contain leucine-rich repeat (LRR) and nucleotide-binding site (NBS) domains. As a group, these genes have been called resistance gene analogs (RGAs). The high degree of sequence conservation among the NBS-LRR class of resistance genes has permitted the design of degenerate oligonucleotides for use in PCR for gene isolation and subsequent development of molecular markers. Defense-related genes associated with broad-spectrum resistance have been targeted to identify effective alleles in rice (Ramalingam et al. 2003). The same approach has been used in chickpea in which C. arietinum RGAs were used to isolate the orthologous alleles from $C$. reticulatum and where alleles were found to cluster into distinct classes, each associated with a known resistance phenotype (Huettel et al. 2002). Other examples of RGA cloning include the use of candidate RGAs to discover alleles for resistance to the soybean mosaic virus Rsv1, Rsv3, and Rsv4 (Liao et al. 2002) and the use of a kinase RGA to mine for alleles for the Co-4 anthracnose resistance locus in common bean (Melotto and Kelly 2001). Divergence of RGA sequences at the Co-y, Co-z, Co-9 locus were studied in common bean and were found to be correlated with the molecular evolution of the anthracnose pathogen at the population level (Geffroy et al. 1999; Ferrier-Cana et al. 2003). The LRR domains are considered the major determinants of recognition specificity for Avr (avirulence) factors and pathogen elicitors, often through direct protein-protein interactions (Leister and Katagiri 2000).

Other Examples of Candidate Gene Allele Mining. There is a rapidly increasing number of functionally annotated sequences associated with stress tolerance, including genes for dehydrin, catalase, glycolate oxidase, and thioredoxin peroxidase that are induced or suppressed as a result of the combined effect of drought and heat shock (Rizhsky et al. 2002). This has led to reports of the mining of desiccation-induced transcripts that may have a role in anthocyanin biosynthesis (Gopalakrishna 
et al. 2001). Another area in which allele mining has been useful is in the explanation of morphological and phenological variation. For example, El-Assal et al. (2001) identified the EDI locus as a QTL partly accounting for the difference in flowering response to photoperiod between two Arabidopsis accessions. Positional cloning of the EDIQTL showed it to be a novel allele of $C R Y 2$, encoding the blue-light photoreceptor cryptochrome-2 that has previously been shown to promote flowering in long-day photoperiods (Guo et al. 1998). Mapping of the vernalization trait to the FRIGIDA locus (FRI) led to mining Arabidopsis ecotypes for FRI alleles in an attempt to identify the underlying genetic differences between the late-flowering and early-flowering ecotypes. An extensive set of FRI alleles was surveyed and the polymorphisms in the form of deletions (31-376 bp) were associated with early flowering (Johanson et al. 2000).

Amongst legumes, the dehydrin candidate gene (Dhn, LEA-D11) has been used in association studies in cowpea to determine the genetic variation underlying chilling tolerance (Ismail et al. 1999). Two types of allelic variation were identified at the protein level (one deletion and two amino acid substitutions), which were confirmed to be functionally significant in inheritance studies. In another study, the molecular nature of the high oleate trait in peanut was examined using the oleoyl-PC desaturase candidate gene $a h F A D 2 B$ wherein a single residue mutation co-segregated with the trait (Jung et al. 2000b). In a similar approach in pea, degenerate primers based on the amino acid sequences of a $49 \mathrm{kDa}$ apyrase (EC 3.6.1.5) were used to screen for alleles in a pea stem cDNA library (Shibata et al. 2001). The cultivated gene pool in a number of legume species (pea, common bean, and cowpea) has been identified as genetically diverse, whereas other legumes (chickpea, soybean, and peanut) possess a narrow genetic base for the cultigen. Sequencing of alleles in one or more of the genetically diverse crops may provide important diversity for crop improvement if allelic differences confer an improved phenotype. In such an approach, the objective is to identify a sequence change that is associated with the improved phenotype. This sequence change can then become the basis of a SNP marker for that allele that can be used in subsequent MAS applications using those new alleles. Variation at the sequence level can also help infer relationships within the legume family from trees that describe the phylogenetic relatedness between the sequences of different alleles.

\section{B. Functional Genomics and Gene Discovery}

Functional genomics refers to the association between sequence and functional phenotypes. Knowing the entire sequence and location of 
genes underlying a target trait is only the first step in determining the relative function and importance of those genes. Functional genomics provides the means to determine the key roles and interactions of these genes that then become the targets for molecular breeding. Different specializations within functional genomics include transcriptomics, proteomics, and metabolomics. The interface between these different areas of functional genomics allows the unequivocal assignment of functions to new plant genes (Holtorf et al. 2002). Plant functional genomics has greatly benefited from technology developments driven by the genomics communities working on humans, yeast, fruit flies, mice, and nematodes. These developments now allow researchers to simultaneously profile vast numbers of different genes or proteins.

Gene discovery has benefited tremendously from developments in high throughput EST sequencing and DNA microarrays. Large-scale analysis of gene expression in Arabidopsis using cDNA and/or oligonucleotide arrays has given new insights into photosynthesis, biotic and abiotic stresses, nitrogen assimilation, and organ development (Desprez et al. 1998; Ruan et al. 1998; Maleck et al. 2000; Schenk et al. 2000; Wang et al. 2000; Girke et al. 2000; White et al. 2000; Zhu and Wang 2000; Bohnert et al. 2001; Seki et al. 2001). Similarly, gene expression analysis in $M$. truncatula and L. japonicus is beginning to elucidate many details of traits that are not well represented in Arabidopsis, including plantmicrobe symbiotic associations with $\mathrm{N}$-fixing rhizobia and with mycorrhizal fungi, defense response, and other agronomic traits such as secondary metabolism and pod development (Penmetsa et al. 2003; Cook 2004; Yahyaoui et al. 2004; Kouchi et al. 2004; Arimura et al. 2004; Naoumkina and Dixon 2004). Among the grain legumes, soybean has the most EST sequences and cDNA libraries developed from a broad range of genotypes, developmental and reproductive stages, organs, tissues, and abiotic and biotic stresses (Shoemaker et al. 2002). In this section, we review examples of different approaches to gene discovery in legumes.

\section{Discovering Candidate Genes Based on Conserved Functional}

Domains. Multi-gene families of related genes control most agronomic traits. These gene families generally evolved through duplication of the original gene followed by sequence divergence of the different copies of that gene. Presumably, during the first phase of such evolution, the generation of allelic variation altered the level of trait expression or conferred expression on different parts of the plant. However, following continued evolution, the different families have often diverged substantially to create new genes encoding new traits affecting adaptation to different environmental stresses or production of new metabolites. In the following section, we give examples of gene families encoding dis- 
ease resistance and affecting nodulation. Clearly, the discovery of genes that have evolved through different evolutionary pathways to influence the same trait requires a different set of approaches than that described here for allele mining.

Using NBS Domains to Discover Disease Resistance Genes in Legumes. Most disease resistance (R) genes in plants share significant homologies in terms of DNA and amino acid sequences as well as structural motifs (Hammond-Kosack and Jones 1997; Dangl and Jones 2001). Nucleotidebinding sites (NBS) and leucine-rich repeats (LRRs) are the most common domains found in plant R-genes where NBS are involved in signal transduction cascades through phosphorylation and dephosphorylation events (Dangl and Jones 2001) and LRRs are a conserved domain involved in ligand binding and pathogen recognition (Hammond-Kosack and Jones 1997).

Degenerate oligonucleotide primers have been used to amplify NBScontaining sequences in near isogenic lines or segregating populations of soybean (Yu et al. 1996; Kanazin et al. 1996; Pennuela et al. 2002), chickpea (Huettel et al. 2002), common bean (Rivkin et al. 1999), cowpea (Gowda et al. 2002), peanut (Bertioli et al. 2003), and alfalfa (Cordero and Skinner 2002). In M. truncatula, over fifty sequences with homology to the NBS domain were obtained using both PCR amplification and database searches and were found to be representative of the NBS sequences of other legumes within the Papilionoid subfamily, establishing $M$. truncatula as a potentially useful model for resistance gene organization (Zhu et al. 2002). In the same study, the genomic locations of RGAs in M. truncatula correlated with those of resistance gene loci in soybean and pea.

Mining Genes Involved in Nodulation. Using molecular genetic technologies such as genome sequencing and gene knock-outs, many of the bacterial genes needed for nodulation (Nod and Nol) and fixation (Fix) have been identified. Similarly, plant genes involved in the nodulation process are also being identified using insertion mutagenesis and positional cloning from the model legumes $L$. japonicus and M. truncatula. The first legume nodulation gene (Nin) was isolated from L. japonicus using transposon mutagenesis with an Ac/Ds transposon system (Schauser et al. 1999). Later, two genes encoding non-nodulation mutants (LjsymRK and MsNORK) were positionally cloned in both $L$. japonicus and M. sativa (Stracke et al. 2002; Endre et al. 2002). Alterations in this gene were revealed when the same gene was cloned from non-nodulating mutants in $M$. truncatula (dmi2) and pea (sym19). Meanwhile, map-based cloning was useful in soybean for the isolation of a nodule auto-regulation receptor kinase (GmNARK), which as a missense 
mutation has a weak nodulation phenotype, while as a nonsense mutation causes extensive super nodulation (Searle et al. 2003). In addition, the lotus LjNin gene has been used to isolate PsNin, an orthologous gene in pea (Borisov et al. 2003). In an approach using EST sequencing, the genome-wide analysis of nodule-specific transcripts in M. truncatula revealed 340 tentative consensus sequences (TCs) that were expressed solely in root nodules and that could be grouped into nine categories based on the predicted function of their protein products (Fedorova et al. 2002). In a similar study using ESTs, Szczyglowski et al. (1997) identified a range of novel ESTs associated with late developmental events during nodule organogenesis in L. japonicus. Parallel experiments have also been initiated in common bean through comparative analysis of 14,000 ESTs from nodule, root, pod, and leaf (Hernandez et al. 2004). The isolation of these candidate genes and the whole field of comparative biology of symbiosis is a role model for comparative genomics studies of other agronomic traits in model legumes and related crops.

2. Studying Candidate Genes Using Microarrays. DNA microarrays, which consist of thousands of gene sequences spotted in high-density array on glass or nylon membranes, are being used for gene expression analysis, polymorphism detection, DNA re-sequencing, and large-scale, whole-genome genotyping (Schena et al. 1995; Chee et al. 1996; Lemieux et al. 1998). The use of microarrays in plants creates extensive databases of quantitative information about changes in gene expression in various tissues or organs in response to developmental processes or changes in the level of pathogens, pests, drought, cold, salt, photoperiod, and other environmental variables. An alternative to DNA spotting of microarrays is the use of photolithography to generate gene chips with tens of thousands of oligonucleotides synthesized directly onto a glass slide (Lockhart et al. 1996; Lipshutz et al. 1999). These gene chips have the advantage that since they are based on short sequences they do not suffer from cross-hybridization of structurally related genes (Wodicka et al. 1997). Although the chips are currently too costly for routine use in many breeding programs, it seems likely that technical innovations and efficiencies associated with expanded use will drive their cost down. While microarray-based characterization of plant genomes has the potential to revolutionize plant breeding and agricultural biotechnology, there are still technical limitations associated with the currently available microarray technology, including high background intensities that obscure signals for weakly expressed transcripts and the difficulty of distinguishing homologous genes due to sequence similarity (Duggan et al. 1999; Gibbings et al. 2003). 
Among the legumes, Maguire et al. (2002) constructed cDNA microarrays for soybean containing 4100 unigene ESTs derived from axenic roots and evaluated their applicability and utility for functional genomics of organ differentiation in legumes. In this study, several ESTs showed high levels (a 50-fold) of differential expression in either root or shoot tissues of soybean. There was a linear correlation $\left(\mathrm{r}^{2}=0.99\right.$, over 5 orders of magnitude) between microarray and quantitative real-time RT-PCR data when a small number of physiologically interesting and differentially expressed sequences found by microarray were verified by both quantitative real-time RT-PCR and Northern blot analysis. Thus microarray analysis of legume has enormous potential not only for the discovery of new genes involved in tissue differentiation and function, but also for studying the expression of previously characterized genes, gene networks, and gene interaction in wild-type, mutant, or transgenic plants. Somatic embryos constitute a model system to study basic aspects of embryogenesis, as well as a tool for efficient transformation. Somatic embryos develop from the adaxial side of the cotyledon, whereas the abaxial side evolves into a callus. Using a 9,280-cDNA clone array, Thibaud-Nissen et al. (2003) identified 495 cDNA clones that are differentially expressed during the development of somatic embryos. Clustering the clones according to expression profile data allowed them to determine the timing of the molecular events taking place during the embryogenesis in soybean.

Soybean Genomics and Microarray Database (SGMD) is a public database that provides an integrated view of the interaction of soybean with the soybean cyst nematode. SGMD contains genomic, EST, and microarray data with embedded analytical tools allowing correlation of soybean ESTs with their gene expression profiles. It also has analytical tools to facilitate the rapid mining of microarray data by integrating many analytical methods within the data itself (http://psi081.ba.ars.usda.gov/ SGMD/default.htm; Alkharouf and Matthews 2004).

A purified yeast elicitor that contains polysaccharides composed entirely of mannose, has been shown to be a strong inducer of the isoflavonoid pathway and to lead to accumulation of phenylpropanoidderived natural products in $M$. truncatula. Using DNA arrays consisting of 16,000 70-mer oliginucleotides designed from a unigene set of M. truncatula EST sequences, Naoumkina and Dixon (2004) observed rapid increases in mRNA levels of specific members of gene families encoding the enzymes L-phenylalanine ammonia-lyase (PAL), chalcone synthase (CHS), caffeoly coenzyme A 3-O-methyl-transferase (CCOMT), isoflavone reductase (IFR), and several other defense genes. Hierarchical cluster analysis revealed a group of these genes with distinct expression patterns. There is a growing interest in genes involved in the 
phenylpropanoid pathway, and thus these genes serve as an internal control for global expression profile analysis.

Temperature stress has a dramatic effect on crop productivity throughout the world. Using cDNA microarrays, Chen et al. (2004) profiled gene expression of mung bean that responded to temperature stress during the germination, and identified many stress-responsive ESTs using the Eisen Cluster and TreeView software (http://www.life.nthu.edu.tw/ islty/). cDNA microarray technology has also been used to study the molecular mechanisms intrinsic to reproductive organ development. Genes specifically expressed during the development of anther and pistil in L. japonicus have been isolated. Cluster analysis of the mircoarray data revealed 21 and 111 independent cDNA groups that were specifically expressed in immature and mature anthers, respectively (Endo et al. 2004). Similarly, Kuster et al. (2004) have reported candidate genes for nodule and arbuscular mycorrhiza development, amongst them different nodulespecific leghaemoglobin and nodule genes as well as a mycorrhizaspecific phosphate transporter gene. This study demonstrates that the Mt6k-RIT arrays serve as useful tools for an identification of genes relevant for legume root endosymbioses. A comprehensive profiling of such candidate genes will provide a new set of gene targets for molecular breeding of crops better adapted to improved cultivation practices.

\section{Identifying Candidate Genes Using Serial Analysis of Gene Expres-} sion (SAGE). SAGE is a powerful technique that provides absolute measures of gene expression based on sequencing of mRNA-derived fragments, or SGAT tags. The technique has been developed to quickly and efficiently survey genome-wide transcript expression. It is best applied to organisms whose genomic sequences are known or that have a substantial cDNA sequence database. Because SAGE tags tend to originate from the $3^{\prime}$ portion of transcripts, they are less effectively screened against most cDNA libraries, which are generally sequenced only from their $5^{\prime}$ ends (Donson et al. 2002). Both SAGE and cDNA microarray techniques have the potential to produce vast amounts of data that must be carefully organized and analyzed in order to be able to draw meaningful conclusions. This becomes a special challenge when data is generated from experiments conducted under many different conditions or locations. To address this issue, Lash et al. (2000) constructed a public gene expression data repository (SAGEmap) and online data access and analysis site (http://www.ncbi.nlm.nih.gov/sage) to maintain SAGE data and to help in gene assignments and statistical testing.

The National Science Foundation (NSF), USA, is supporting a project (http://soybean.ccgb.umn.edu/) to stimulate basic and applied research on functional genomics of soybean through the development of tools for 
global gene expression analysis. The main objectives are to build a soybean "unigene" set defined by 5 ' and 3 ' sequence data, to construct and use microarrays for global expression, and to generate and sequence SAGE-tagged libraries. To date, this project has constructed $20 \mathrm{cDNA}$ libraries and generated 132,992 SAGE tags, of which 40,121 are unique, in soybean (http://soybean.ccgb.umn.edu). Similarly, over 70,000 3' ESTs, have been obtained from normalized and size-selected cDNA libraries made from different organs of $L$. japonicus, and these cluster into over 20,000 unigenes (Asamizu et al. 2000).

Substantial developments have recently been made to create the SuperSAGE methodology (Matsumura et al. 2003), which uses the type III restriction endonuclease EcoP15I, to isolate tags of $26 \mathrm{bp}$ in length from defined positions of cDNAs. This approach will be especially useful for transcriptome profiling of two or more interacting organisms like host and pathogens. SuperSAGE has been applied to Maganporthe grisea (blast)-infected rice leaves to simultaneously study gene expression profiles of both the rice host and blast fungus. This was possible because the genomes of both organisms have been fully sequenced. However, the methodology can also be used with organisms that do not have whole genome sequence databases.

4. Dissecting Entire Metabolic Pathways. Metabolites are the final products of gene expression, and the comprehensive large-scale analysis of metabolites is termed metabolomics. Metabolite profiling is usually achieved through the use of gas chromatography or mass spectrometry. These qualitative and quantitative analyses provide a holistic view of the biochemical status or biochemical phenotype of an organism. The use of metabolite profiling is an important tool for comparative display of gene function that has the potential not only to provide deeper insight into complex regulatory processes but also to directly determine metabolic phenotypes (Fiehn et al. 2000). In this section, we provide some key examples in which the metabolic pathways underlying important agronomic traits in legumes have been sufficiently well dissected to see likely practical impacts.

Isoflavonoid Biosynthesis. Isoflavonoids are a specialized form of flavonoids, synthesized exclusively in legumes. They are reported to reduce the occurrences of certain types of cancers, reduce postmenopausal symptoms, prevent coronary heart disease, and have positive effects on neurobehavioral activities. The isoflavonoid synthesis pathway is probably the best-characterized natural product pathway in plants (Dixon and Steele 1999). Roessner et al. (2001) developed a metabolic profiling technique based on gas chromatography-mass spectrometry technology that 
allows detection of a wide range of hydrophilic metabolites within a single chromatographic run. This approach was used to study potato sucrose metabolism, demonstrating the use of metabolic profiling in conjunction with data-mining tools as a powerful technique for the comprehensive characterization of a plant genotype. For details, the readers may refer to a review article on isoflavone biosynthesis pathways that focuses on key structural enzymes and transcription factors, and on progress in metabolic engineering of isoflavone biosynthesis in both legume and non-legume plants (http://www.oardc.ohio-state.edu/soydefense/silencing/yupubs/ metabengineer.pdf).

Isoflavone synthase catalyzes the first committed step of isoflavone synthesis, a branch of the phenylpropanoid pathway. Soybean contains the highest level of isoflavones, roughly more than 100-fold higher than many other legumes (http://www.nal.usda.gov/fnic/foodcomp/data/ isoflav/isoflav.html). Jung et al. (2000a) identified two soybean genes encoding isoflavone synthase that they then used to isolate homologous genes from other leguminous species, including red clover, white clover, hairy vetch, mung bean, alfalfa, lentil, snow pea, and lupine. Identification of isoflavone synthase genes should allow manipulation of the phenylpropanoid pathway for agronomic and nutritional purposes. Dhaubhadel et al. (2003) detected isoflavonoids in all organs of soybean plants, but the amount varied depending on the tissue and development stage; the greatest concentrations were found in mature seeds and leaves. Using 2-hydroxyisoflavonone synthase genes (IFS1 and IFS2), they determined patterns of expression in different tissues and developmental stages. The highest expression of IFS1 was in the root and seed coat, while IFS2 was mostly expressed in embryos and pods and in elicitor-treated or pathogen challenged tissues. Developing soybean embryos have an ability to synthesize isoflavonoids de novo but transport from maternal tissues may also contribute to the accumulation of these natural products in the seed.

Thiol Tripeptides Synthesis Pathway. The thiol tripeptides, glutathione (GSH) and homoglutathione (hGSH), perform multiple roles in legumes, including protection against toxicity of free radicals and heavy metals. Matamoros et al. (2003) characterized three genes involved in the synthesis of GSH and hGSH in the model legume L. japonicus, where they are present as single copies. The y-glutamylcysteine synthetase (yecs) gene mapped on the long arm of chromosome 4 (70.0 cM), whereas the glutathione synthase (gshs) and homoglutathione synthase (hgshs) genes mapped on the long arm of chromosome $1(81.3 \mathrm{cM})$ arranged in tandem with a separation of approximately $8 \mathrm{~kb}$. The promoter regions of yecs, 
gshs, and hgshs contain regulatory elements related to a plant's response to light, hormones, and stress conditions. Determination of transcript levels, enzyme activities, and thiol contents in nodules, roots, and leaves revealed that yecs and hgshs are expressed in all organs, whereas gshs is functional at significant levels only in nodules, strongly suggesting an important role of GSH in the rhizobia-legume biosymbiosis.

Triacylglycerol Synthesis Pathway in Lupin. Oil content and quality are fundamental agronomic traits of oil-seed legumes such as soybean, peanut, and lupine. Oil quality is determined by triacylglycerols (TAGs) that are stored as seed energy reserves. In a comparative study of two lupin species, L. mutabilis (high oil species) and L. angustifolius (low oil species), Francki et al. (2002) cloned a differentially-expressed glucose dehydrogenase-like gene and compared expression levels of this gene and other key enzymes of the lipid biosynthetic pathway, including acetyl-CoA carboxylase (ACCase) and diacylglycerol acyltransferase (DAGAT), in an attempt to explain differences in TAG accumulation.

Symbiosis with Rhizobium and Mycorrhiza. Root protein profiles have been studied during root development and nodule formation in M. truncatula. Hundreds of proteins are induced during nodule formation (Mathesius et al. 2001; Bestel-Corre et al. 2002). In experiments with different arbuscular mycorrhiza (AM) species, Burleigh et al. (2002) found that different species vary widely in their expression of root-specific genes involved in response to phosphorous starvation. For example, Glomus mosseae colonization of $M$. truncatula resulted in the greatest reduction in MtPT2 and Mt4 gene (phosphorous starvation-inducible plant genes) expression and the highest level of phosphorous uptake and growth. At the other extreme, Gigaspora rosea, whose colonization resulted in the highest level of MtPT2 and Mt4 gene expression, had the lowest phosphorous uptake and growth. In addition, other legumes may have a differential response to mycorrhiza at the level of colonization, nutrient uptake, and growth both in terms of profile and level of gene expression.

Seed Development and Germination. Seed germination is a complex physiological process but a highly important component of crop productivity. In farming systems, seed priming is often used to accelerate germination and improve uniformity of crop establishment. Proteomic analysis of Arabidopsis seed germination and priming revealed changes in the abundance (up- and down-regulation) of the 74 proteins observed during germination and the specificity of certain proteins with certain phases of seed germination (Girke et al. 2000; Gallardo et al. 2001). 
More recently, advances have also been made in our understanding of how metabolic networks are regulated at the protein level during reserve deposition in seeds in M. truncatula (Gallardo et al. 2003). This information should be useful for the analysis of seed development in legumes that may help in the engineering of legume seed composition for increased yield and enhanced end-user value.

These discoveries highlight the power of proteomics and metabolomics to unravel specific features of complex developmental processes and to provide candidate protein markers for traits of commercial importance. It is expected that in turn the underlying genetic markers will be identified that can be used as candidate gene-markers in molecular breeding programs.

\section{New Technologies for Marker-Assisted Selection}

1. High-Throughput SSR Marker Genotyping. The throughput potential and unit cost of virtually all PCR-based assays can be substantially increased with readily available semi-automated technologies developed largely to serve the mass sequencing market. Although this requires significant investment in equipment, protocol development, and optimization, this is nevertheless appropriate even for lesser-studied crops, as ICRISAT has achieved for chickpea, groundnut/peanut, and pigeonpea. One of the most compelling reasons for adopting this approach is the opportunity to scale-down reaction volumes. For example, moving from a total reaction volume of $10 \mu \mathrm{l}$ to $5 \mu \mathrm{l}$, moving from 96 well to 384 well format, and pooling PCR products prior to electrophoresis detection has substantially reduced unit costs. Further reductions in PCR costs can be achieved through optimization of the individual component concentrations. Although the optimization process is laborious, it also improves the efficiency of the PCR, resulting in fewer spurious amplification products.

A major constraint to large-scale genotyping is resolving the resultant bottlenecks at the DNA extraction stage and data management and analysis steps. The genotyping process invariably starts with DNA sample preparation and it is important that the DNA be of the highest quality, as this has a huge impact on whether robust, easily callable data is generated. Low-cost high-throughput DNA extraction protocols must be developed for each specific crop of interest, as has been achieved for ICRISAT mandate crops (Mace et al. 2003). Although commercial kit options are available, these are too expensive for routine use in molecular breeding programs. Conversely, although there are many reports of large-scale low-cost DNA extraction systems, these rarely provide the 
quality of DNA required for trouble-free reliable applications in highthroughput genotyping systems. Similarly, Laboratory Information Management Systems (LIMS) and Decision Support Systems must be developed to serve the unique demands and processes of each lab (Ermolaeva et al. 1998).

The M.S. Swaminathan Applied Genomics Lab at ICRISAT uses 96well DNA extraction, 8-tip liquid handling robotics, 96-capillary semiautomated genetic analysis, and high-throughput data management systems tailored to applications in all five mandate crops: sorghum, pearl millet, chickpea, groundnut/peanut, and pigeonpea (ICRISAT 2002a). This lab is almost entirely dedicated to germplasm diversity analysis, trait mapping, and marker-assisted breeding with less than $5 \%$ of throughput used for sequencing or functional genomics research. This type of genotyping potential is particularly valuable for QTL mapping of complex traits, in which a large number of markers $(n>100)$ need to be screened across a range $(n>3)$ of large populations $(n>250)$.

The use of high-throughput semi-automated genotyping systems for PCR-based markers, such as SSR markers, dramatically increases the efficiency of data collection while reducing the cost per data point compared to manual systems. It was not uncommon in the early 1990s, particularly in lesser-studied crops, to see genotyping costs of US \$5 per sample (including DNA extraction, RFLP analysis, and data collection). During the mid-1990s there were several reports of US $\$ 2$ or even US \$1 per sample. For example, Concibido et al. (1996) estimated a cost of US $\$ 2.00$ per data point for RFLP compared to US \$1.50 per data point for SSR fingerprinting for cyst nematode resistance using marker-assisted selection. Similarly, the high-throughput human genotyping project estimated unit costs of US $\$ 1.00$ per SSR data point (Hall et al. 1996). However, \$1 per sample is prohibitively high for many breeding programs. Most recently, the high-throughput genotyping facility at the University of Georgia reported developing a soybean genotyping pipeline capable of generating 7500 SSR data points per week at an estimated cost of around US $\$ 0.50$ per data point (http://www.gsf99.uiuc .edu/invited/2_2_01.pdf). So costs are clearly falling, but unfortunately it is not possible to compare directly most cost analyses presented in the literature, as these often do not include all relevant costs such as DNA extraction and data collection, labour, and equipment depreciation. Moreover, once a particular marker has been reliably associated with an important trait of interest, there are then a wide range of options for optimizing, refining, or even transforming that marker to reduce the unit costs of large-scale screening. 
2. Simple Markers from Fingerprinting Assays. The conventional marker assays including RFLP, RAPD, AFLP, and SSR have greatly contributed to our current understanding of genome organization and genetic variation. However, they are constrained by their dependence on gel electrophoresis, resulting in low throughput through manual systems and limited scalability even if detection can be automated. Moreover, these methods are based on size separation of multiple DNA fragments and thus suffer from difficulties in precisely correlating bands on gels with allelic variants.

\section{Sequence Characterized Amplified Region (SCAR) Markers. RAPD} markers belong to the dominant class of genetic markers, have poor reproducibility, and their application in marker-assisted selection (MAS) is severely limited. Transforming a RAPD marker into a SCAR marker generally improves reproducibility and increases throughput potential in MAS programs (Paran and Mitchelmore 1993) and offers the possibility of eliminating the use of gel electrophoresis (Gu et al. 1995). However, developing a SCAR marker is laborious and tight linkage of the RAPD marker to a gene (or QTL) of interest must be confirmed before converting RAPD bands into SCAR markers. Tightly linked RAPD markers are reported for resistance to common bacterial blight, fusarium wilt, and bean common mosaic virus in common bean (Miklas et al. 2000; Yu et al. 2000; Fall et al. 2001) and for ascochyta blight resistance in lentil (Chowdhury et al. 2001). The utility of SCAR markers in MAS has been demonstrated for the selection of resistance to common bacterial blight in common bean (Yu et al. 2000) and for resistance to ascochta blight in lentil (Chowdhury et al. 2001). However, development of SCAR markers may also be associated with a loss of detectable polymorphism, as was seen when a RAPD fragment (UBC227 ${ }_{1290}$ ) was converted into a SCAR marker in lentil (Chowdhury et al. 2001).

Single Locus or Allele-Specific Assays from AFLP. Amplified fragment length polymorphism (AFLP) technology is based on the PCR amplification of selected restriction fragments of a total genomic digest. Separation of labeled amplified products is then achieved through denaturing polyacrylamide gel electrophoresis (Vos et al. 1995). Unlike SSR and RFLP, a priori knowledge of genome structure is not required for AFLP assays, which also have the added advantage of generating a large number of amplification products. Thus, AFLP analysis is particularly valuable for diversity analysis and background genome selection in marker-accelerated backcross programs. However, AFLP assays are less suitable for allele frequency studies, marker-assisted selection, or mapbased cloning, as many AFLP markers are redundant and hence the 
assay becomes too expensive and too laborious for large-scale single locus screenings (Liu et al. 1998). On this basis, the use of AFLP analysis in linkage mapping must be followed by the conversion of specific AFLP markers into single locus PCR markers, such as cleaved amplified polymorphic site (CAPS) markers (Konieczny and Ausubel 1993) or sequenced characterized amplified region (SCAR) markers (Paran and Mitchelmore 1993). However, conversion of AFLP markers from complex fingerprints into simple single locus assays can be problematic, as DNA sequence information is required to design new locus-specific PCR primers, and single locus polymorphism information is required to design an allele-specific assay. Nevertheless, Brugmans et al. (2003) describes a procedure demonstrating a high success rate for the conversion of AFLP markers (from rather small $131 \mathrm{bp}$ to large $359 \mathrm{bp}$ size fragments) into locus-specific markers in tomato (Lycopersicum esculentum) and flax (Linum ussitatisimum).

There are few reports of the successful conversion and application of SCAR-based AFLP markers. Five AFLP markers were converted to CAP and SCAR markers associated with resistance to clubroot disease in Brassica (Piao et al. 2004). Similarly, AFLP-derived SCAR markers have been utilised in fine mapping of the $V f$ region controlling resistance to fungal disease in apple (Huaracha et al. 2004), for seed coat colour in Brassica (Negi et al. 2000), for development of sorghum downy mildew resistance gene markers in maize (Agrama et al. 2002), and for resistance to lodging in pea (Tar'an et al. 2003b) and Striga gesneriodes in cowpea (Boukar et al. 2004).

3. Gel-free Diagnostics. TaqMan technology relies on the use of a 20-30 bp probe labeled with a fluorescent reporter dye and a fluorescent quencher dye, which detect specific sequence polymorphisms in PCR products. The TaqMan probe hybridizes to a complementary region within the PCR product; during the process of amplification, the TaqMan probe is degraded due to the $5^{\prime} \rightarrow 3^{\prime}$ exonuclease activity of Taq DNA polymerase. This leads to a release of the quenching effect on the reporter component of the probe, resulting in an increase of fluorescence intensity of the reporter dye. The light emission increases exponentially through subsequent PCR cycles and can be measured by spectrophotometry during or at the end of the PCR. The TaqMan assay is useful in diagnostic applications, such as the screening of samples for the presence or incorporation of favorable traits and the detection of pathogens and diseases.

The TaqMan assay allows high sample throughput, because no gelelectrophoresis is required for detection, and short analysis time, as the 
reaction can be stopped as soon as a significant amplification difference is detected. The major disadvantages with this technology are: requirement for sequence data for primer and probe construction, high unit costs due to the requirement for the fluorogenic probes/quencher, and potential inefficiencies from single allele specific tests if no allied approach is employed to distinguish false negatives (PCR failures) from true negatives (absence of allele). Indeed, it has been reported that TaqMan screening for detection of a candidate gene $R h g^{4}$ conferring resistance to soybean cyst nematode was accurate in only $90 \%$ of RIL progeny compared to 95\% accuracy during conventional electrophoresis (Meksem et al. 2001c). Clearly, this is unacceptable for large-scale application of a capital and operationally expensive assay. Fortunately, it is likely that in most cases precision and accuracy can be readily increased to more acceptable levels through intensive optimization.

A rapid TaqMan assay has been developed to assess the dosage of the dihydroflavonol 4-reductase $(d f r)$ allele in cultivated potato, which is associated with red-skinned cultivars (Jong et al. 2003). Through the use of fluorogenic allele-specific probes, one for red allele and the other for "not-red" $d f r$ alleles, a TaqMan allelic discrimination assay clustered the diploid clones tested into three distinct groups (homozygous for the red allele, heterozygous for the red allele, and homozygous for the notred allele), based on the relative amount of two different dyes released. The assay has been reported to successfully discriminate allelic dosage in autopolyploid potato (Jong et al. 2003).

The development of microplate or filter-based detection systems is likely to be an important component intervention for the more widespread adoption of MAS technologies in developing countries. In particular, the availability of allele-specific gene-based marker systems will have a substantially higher throughput potential than gel-based system assays, while requiring less expertise and expense. Clearly the development of low-cost high-throughput DNA extraction and PCR amplification systems is a parallel requirement toward providing a complete appropriate package for tropical breeding programs. The Generation Challenge Program is currently addressing these issues on behalf of the wider community.

4. Trait-Specific SNP Markers. Recent technological advances in DNA sequence analysis and the establishment of DNA-chip technologies have provided the framework for large-scale discovery and analysis of DNA variation. Single nucleotide polymorphisms (SNPs) are markers that focus on variation at the nucleotide level within the genome. However, this approach does require $a$ prior knowledge on the allelic nature of the variations within the genome for the genetic population under study. 
There are a number of approaches used for the development of SNPs: screening ESTs for polymorphic sites (Zhu et al. 2003a; Choi et al. 2004b) or through an enriched shotgun genome sequencing methodology involving multiple individuals (Altshuler et al. 2000). There is much interest in SNP markers due to their highly multiplex nature and ease of automated detection, resulting in the generation of more data points per unit time than with any other marker system. Indeed, the rationale of the HapMap project in humans is to focus on SNPs associated with disease traits. The eventual aim is to be able to scan the entire genome by genotyping fewer than 500,000 SNPs as opposed to 10 million common SNPs (International HapMap Consortium 2004). Research in plants lags far behind humans and animals. However, there are a few examples that suggest the plant community is moving in a similar direction. For example, several of the multinational breeding companies are highly focused on SNP-based markers in their soybean molecular breeding programs (Cahill 2000). In the public sector, soybean unigenes ESTs have been used for SNPs discovery in soybean as well as several other legume species including common bean, cowpea, chickpea, pea, peanut, and Medicago truncatula. For example, when 1,204 soybean-derived sequence tagged sites (STS) were amplified in other legume species, $15.3,13.8,6.1,5.6,2.7$, and $2.7 \%$ of the 1204 primer sets were able to generate sequencable products in genomic DNA of $P$. vulgaris, $V$. unguiculata, C. arietinum, M. truncatula, P. sativum, and A. hypogea, respectively (http://www.Embrapa.br/labex/download/perry/-cregan-groupposter.pdf). The frequency of SNPs in soybean is somewhat low: between 1.98 SNPs per kbp (coding DNA) and 4.68 SNPs per kbp (noncoding DNA), as estimated from the analysis of 25 soybean genotypes (Zhu et al. 2003a). Trait specific SNPs have also been identified in barley for the Mlo gene and have been used by breeders as a routine assay for marker-assisted selection for mlo-mediated resistance to powdery mildew in barley at the seedling stage (Paris et al. 2003).

5. Array-Based Genotyping. There is no doubt that with the use of robotics and capillary electrophoresis (CE), the cost of SSR genotyping will continue to fall as marker sets are further optimized, multiplex PCR and CE co-loading sets and conditions elucidated, and high-throughput genotyping systems further refined. Similarly, the comparative advantage of SSR markers as a research tool for linkage analysis and QTL mapping is likely to remain for some time to come. However, to reach a compelling costbenefit threshold for large-scale routine molecular breeding applications, there is significant need to reduce genotyping costs below $\$ 0.10$ per sample (including costs from DNA extraction to data analysis). At the same time, there is significant pressure to provide a unified system capable of 
simultaneous foreground selection of multiple complex traits and background selection of the recurrent parent genome. Achieving this level of scale-up and or cost effectiveness will require the application of an entirely different type of genotyping platform.

Although hybridization technologies gave way to PCR-based markers during the 1990s in the quest for automation, in the current decade hybridization approaches (now miniaturized through array technology) are returning as the best solution for cost-effective scaling-up of marker-aided selection. However, before that can happen, substantial genomic resources must be generated in the crop of interest and a range of technical issues must be resolved to ensure reliable DNA-DNA or cDNA-cDNA hybridization of hundreds or thousands of DNA templates on a single tiny matrix.

The quest for genome-wide analysis of expression led to the development of a number of array-based approaches, including macroarrays (Desprez et al. 1998) and microarrays (Schena et al. 1995). DNA chips are based on binding random or known DNA fragments or oligonucleotides onto a microscope slide, displaying up to 409,000 spots in an area of $1.28 \mathrm{~cm}^{2}$ (Fodor 1997), and detecting mRNA at levels of 1/100,000 or 1/500,000 (Gerhold et al. 1999).

Diversity arrays technology (DArT) (Jaccoud et al. 2001; http:// www.cambia.org.au/main/diversityarrays.htm) is a novel methodology for genotyping a large number of arbitrary genome-wide markers using array technology. It is a low-cost high-throughput robust system, a sequence-independent form of genotyping, and requires a minimal DNA sample to provide comprehensive genome coverage. Although this approach has been successfully applied in Arabidopsis, rice, cassava, wheat, barley, apple, and a forage grass (Jaccoud et al. 2001; Peng et al. 2002; Patarapuwadol et al. 2004), it has been difficult to establish routine applications in the lesser-studied crops in which its use is the most justified.

Conventional microarray analysis interrogates the target or template RNA or DNA in solution using DNA probes on the array slide. This is well suited to linkage mapping studies in which thousands of markers must be screened across hundreds of individuals. However, more recently the reverse arrangement has been employed such that amplified PCR products from thousands of individuals are spotted on an array slide and screened with a small number of labeled probes. The approach is known as Tagged Microarray Marker (TAM) (Flavell et al. 2003). TAM is highly suitable for large-scale analysis with a small number of codominant molecular markers based on retrotransposon insertion sequence polymorphisms or SNPs. The cost for TAM is estimated at 6 
cents per assay, with an initial capital equipment cost of approximately $\$ 100,000$ for the microarrayer and scanner (Flavell et al. 2003).

Low-cost high-throughput assay technologies will be a critical element of regional shuttle genotyping hubs where breeders from NARS partners and indigenous seed companies can achieve large-scale cost-effective MAS using state-of-the art facilities. Building molecular breeding success stories without substantial capital investment is likely to be an important intermediate step for more widespread adoption of MAS technologies in developing countries. However, it is far from clear which technology offers the best opportunity for MAS applications in these settings. Thus, multi-site and multi-application evaluation of a range of these technologies is an urgent priority that the Generation Challenge Program is currently addressing on behalf of the wider community.

\section{Successful Applications of Molecular Breeding in Legumes}

Marker-assisted selection (MAS) is most useful for traits where phenotypic evaluation is expensive or difficult, particularly for those polygenic traits with low heritability that are highly affected by the environment (Nienhuis et al. 1987). Indirect selection based on marker genotype rather than phenotype can be used to accelerate the speed and increase the precision of genetic progress, as well as reducing the number of generations and in turn lowering costs. Marker-assisted breeding can also break linkages between the target traits and undesirable genes (Young and Tanksley 1989). MAS is accomplished through the positive selection of markers tightly linked to (or within) genes of interest (often referred to as foreground selection) while marker-accelerated backcross (MAB) involves the concomitant negative 'negative background selection' of marker alleles elsewhere across the donor parent genome (Tanksley et al. 1989). The efficiency of MAS and MAB depends on the size of the population, the number of markers used, the distance between marker loci, the genomic region containing the desired quantitative trait loci (QTL), and the experimental design used in the marker association studies (number of replications, locations, and seasons plus size and type of population). The effectiveness of MAS decreases as the distance between the marker and target QTL increases because of the increased probability of recombination between marker and trait loci and thus the increased probability of false positives or false negatives. Similarly, selective power may be lost due to differences in recombination patterns in the breeding population as compared to the genetic population used for the original marker-trait association. Thus, validation of QTL markers is a critical precursor to routine use in applied breeding programs. 
At least four levels of validation can be envisaged for use: a different population from the same cross, a half-sib population, a population from one or more closely related parental genotypes, and a population from distantly related parental genotypes. These populations should also be phenotyped in a number of different environments to simultaneously detect environmental (E) effects and QTL $\times$ E interactions for the putative QTL. Trait heritability, the proportion of additive genetic variance explained by the marker loci affecting the trait, and the selection method used all influence the selection efficiency of both conventional and marker-assisted breeding programs.

Deleterious linkage drag is the most frequent reason given by plant breeders for not making extensive use of exotic germplasm for the introgression of novel traits. The extent of linkage drag depends upon the population size, the number of meiotic generations before selection is applied, the size of the donor genome segments retained, and the genomic location of the locus of interest (Hanson 1959; Stam and Zeven 1981; Young and Tanksley 1989). However, in most cases, MAS can provide a substantial improvement over conventional introgression and backcross breeding. Of course, MAS cannot help when the perceived linkage drag turns out to be deleterious pleiotropy of the target gene.

The literature now contains hundreds of research articles reporting the development of markers, identification of polymorphisms amongst cultivated and wild germplasm, constructing of genetic linkage maps, and QTL mapping of economically and agronomically important traits (see Tables 6.15 to 6.22 ; also see section V B). MAS is now routinely used in the breeding of many major cereal crops (Ahmadi et al. 1992; Yoshimura et al. 1995; Ribaut et al. 1997; Huang et al. 1997; Tuvesson et al. 1998; Hittalmani et al. 2000; Chen et al. 2000; Sanchez et al. 2000; Robert et al. 2001; Thomas 2003; Xu et al. 2004). In contrast, there are relatively few reports on the application of MAS in legume crops. The ratio of MAS and $\mathrm{MAB}$ reports compared with the number of research articles on the mapping of agronomic traits is surprisingly low in both cereal and legume crops. In this section, we briefly discuss the few documented cases in soybean, common bean, lentil, and pea that have demonstrated the effectiveness of MAS in legume breeding.

\section{Soybean}

Nematodes. The soybean cyst nematode (SCN) is one of the most economically destructive pests of soybean (Noel 1992). Conventional breeding for SCN resistance is difficult because multiple genes control this characteristic (Caviness 1992) and nematode populations are geneti- 
cally heterogeneous (Niblack 1992). One major locus conferring partial resistance to SCN has been identified that controls more than $50 \%$ of variation in resistance against several races of the nematode (Concibido et al. 1994, 1996, 1997; Web et al. 1995). Marker-assisted selection using the SSR marker Satt309 (located only 1-2 cM away from the rhg1 locus) now forms the basis of most public breeding efforts (Cregan et al. 1999b; Mudge et al. 1997). Indirect selection with Satt309 was 99\% accurate in predicting lines that were susceptible in subsequent greenhouse assays (Cregan et al. 1999b). Wang et al. (2001a) reported two major QTL that confer resistance to race 3 of the soybean cyst nematode in an $\mathrm{F}_{2}$ population (A81-356022 $\times$ G. soja) and they further confirmed these QTL in a population of $100 \mathrm{BC}_{1} \mathrm{~F}_{2}$ plants developed by crossing A81-356022 to a line from the $\mathrm{F}_{2}$ population that carried the two resistance QTL from G. soja.

Earworm. MAB approaches have also been used to pyramid a QTL conditioning corn earworm resistance in the soybean line PI 229358 together with $c r y 1 A c$ transgene from the recurrent parent Jack-Bt (Walker et al. 2002). When $\mathrm{BC}_{2} \mathrm{~F}_{3}$ plants with or without the cry1Ac transgene were subjected to leaf feeding bioassays with corn earworm and soybean looper larvae, few larvae of either species survived on leaves expressing the $c r y 1 A c$ protein. Though not as great as the effect of $c r y 1 A c$, the PI 229358-derived QTL also had a detrimental effect on larval weights of both pest species. The combined deployment of transgene and QTLmediated resistance to a lepidopteran pest may be the most viable strategy for control of insect pests.

Seed Weight. This is an important component of yield, as well as an important aspect of market preference in soybean. Mian et al. (1996a) identified seven and nine independent RFLP loci associated with seed weight in population 1 (Young $\times$ PI 416937) and population 2 (PI 97100 $\times$ Coker 237), respectively. Together these loci explained at least $73 \%$ of the variability in seed weight with a heritability of at least $90 \%$. The six marker loci associated with seed weight in each population were highly consistent across environments and years, which is a critical precursor to the development of an effective MAS program. Hoeck et al. (2003) identified SSR markers associated with QTL for seed size and compared the effectiveness of phenotypic selection and MAS for seed size in three populations of soybean. Population 1 had 12 markers that individually accounted for $8.1 \%$ to $14.9 \%$ of the variation for seed size combined across environments, population 2 had 16 markers that individually accounted for $7.8 \%$ to $36.5 \%$ of the variation, and population 3 had 22 markers that individually accounted for $8.6 \%$ to $28.8 \%$ of the 
variation. In this study, phenotypic selection for seed size was at least as effective as and less expensive than MAS. The lack of added value for MAS of this trait is an important example of the need for establishing clear justification prior to the development of MAS systems. This trait has high heritability in soybean ( 0.45 to 0.93 ) and is relatively easy to accurately and precisely phenotype and, thus on this basis at least, does not present a compelling case for needing marker-aided intervention.

2. Common Bean. The development of integrated consensus linkage maps in common bean, including the map locations of disease and insect pest resistance genes, has provided a sound basis for the development of MAS systems for disease resistance in bean that are now routinely carried out in many bean breeding programs (Kelly et al. 2003).

Bacterial Blight. Breeding for common bacterial blight (CBB) resistance in common bean is complicated by pathogen variability (Schuster et al. 1983), linkage of resistance with undesirable traits (Beebe 1989), and different genes conditioning resistance in leaves, pods, and seeds (ArnaudSantana et al. 1994). Two RAPD markers (R7313 and R4865) linked to genes conferring resistance to CBB have been reported in Phaseolus vulgaris (Bai et al. 1997). Tar'an et al. (1998) examined the use of these markers for selecting CBB resistant material from $\mathrm{F}_{5: 6}$ recombinant inbred lines (RILs). The two markers located on the same linkage group accounted for $22 \%(\mathrm{P}=0.0002)$ of the variation for resistance to CBB. Seventy percent of the lines that possessed both markers were observed to be resistant, whereas $73 \%$ of the lines that had neither of the RAPD markers were susceptible. This indicates that these disease resistance markers are stable and of potential value for plant breeding programs. $\mathrm{Yu}$ et al. (2000) reported a RAPD marker, BC420 ${ }_{900}$, significantly associated with a major QTL that accounted for approximately $62 \%$ of the phenotypic variation for resistance to CBB in HR67. When converted into a sequence characterized amplified region (SCAR) marker and used for selection in a different population (Envoy $\times$ HR67), the prediction of resistance was $94.2 \%$ accurate. The estimated cost for using SCAR and RAPD markers to analyse 100 bean lines is around US $\$ 4.50$ per data point, respectively, whereas conventional greenhouse screening costs nearly $\$ 7.00$ per data point. The greenhouse test requires more than 30 days, whereas MAS can be completed in about one week.

Anthracnose. Resistance to anthracnose (Colletotrichum lindemuthianum) in the cultivar 'TO' is monogenic and controlled by a dominant resistance gene, Co-4 (Bassett 1996), which is different and independent of other anthracnose resistance genes, $\mathrm{Co}-1, \mathrm{Co}-2, \mathrm{Co}-3, \mathrm{Co}-5$, and $\mathrm{Co}-6$ (Fouilloux 1979; Young et al. 1998). The gene Co-4 is reported to be 
effective against 22 of the 25 C. lindemuthianum pathotypes identified in Brazil (Rava et al. 1994), and is an important source of resistance used by several breeding programs (Fouilloux 1979; Pastor-Corrales et al. 1994; Young and Kelly 1996, 1997). Six RAPD markers linked to the Co-4 genes have been reported: four in coupling and two in repulsion phases. The combined use of both markers allows the differentiation of homozygous and heterozygous resistant plants with selection efficiencies of $100 \%$ and $98 \%$, which shows that it is possible to develop codominant assays from RAPD markers providing both repulsion and coupling phase markers are available for the gene of interest (de Arruda et al. 2000).

Rust. The Guatemalan black bean (Phaseolus vulgaris L.) genotype PI 181996 is resistant to all known races of the bean rust. Johnson et al. (1995) investigated the value of two RAPD markers $\left(O A C 20_{490}\right.$ in coupling and OAE $10_{890}$ in repulsion phases) linked to rust resistance in PI 181996, using a diverse group of common bean cultivars and breeding lines. All the cultivars into which PI 181996 resistance was introgressed had the RAPD OAC20 ${ }_{490}$.

Drought. Breeding for a highly complex quantitative trait like drought tolerance could be substantially assisted by the development of MAS systems capable of identifying tolerant genotypes in early generations. Schneider et al. (1997) identified four RAPD markers that were consistently and significantly associated with yield under stress, yield under optimum irrigation, and geometric mean yield across a broad range of environments. Using these markers in breeding populations from the same parental genotypes as the mapping populations generated individuals with $11 \%$ increase in yield under drought stress, whereas conventional selection based on yield performance failed to increase performance in the USA. However, when a parallel validation was carried out in Mexico, the markers were not found to offer any advantage over conventional selection.

Seed Yield. A procedure for MAS of complex traits in common bean using an index based on QTL-linked markers and genetic distances between lines and a target parent has been reported (Tar'an et al. 2003a). A comparison of the mean seed yields of the top five lines selected by different schemes demonstrated that the highest-yielding group was selected on the basis of a combination of phenotypic performance and a high QTL-based index, followed by groups identified by a high QTLbased index, conventional selection, and a low QTL-based-index. This study also showed that the use of the QTL-based index in conjunction with genetic distance to the target parent would enable a plant breeder to select lines that retain important QTL in a desirable genetic background. 
Thus, it is increasingly clear that the greatest gains will be achieved through the best combination of molecular and conventional approaches and not through either alone.

\section{Lentil}

Ascochyta and Anthracnose. Ascochyta blight and anthracnose are the two most destructive diseases of lentil. Two genes are believed to confer resistance to Ascochyta blight (ral1 and AbR1), while a single gene is reported to control resistance to anthracnose (95B36 isolate). Tar'an et al. (2003c) pyramided the two genes for resistance to Ascochyta blight together with the gene for resistance to anthracnose in F6:7 RILs (CDC Robin $\times 964 a-46$ ). More than $82 \%$ of the lines that had either or both of the Ascochyta blight resistance (18\% false negatives) markers were resistant, while $80 \%$ of the lines that had neither marker were susceptible ( $20 \%$ false positives). When a parallel validation was carried out using different ascochyta blight isolates, the selective power was slightly lower with $26 \%$ false negatives and $21 \%$ false positives. Similarly, screening with the anthracnose marker correctly identified $85 \%$ of the resistant lines. These validation studies suggest good potential for marker-assisted disease resistance breeding in lentil. Although the selective power of these markers does not appear especially high, it is likely that this is partly due to the innate problems associated with the reproducibility of this assay. Thus, the development of SCAR or allele-specific assays from these markers would surely increase the robustness and power of selection of marker-assisted disease resistance breeding in lentil.

\section{Pea}

Mycosphaerella Blight. Tar'an et al. (2003b) identified two major QTL that together explained $58 \%$ of the total phenotypic variation associated with lodging resistance in RILs evaluated over 11 environments in Canada. They converted the most important AFLP band into a SCAR marker (A001). The presence or absence of A001 corresponded well with the known lodging reaction of 50 commercial pea cultivars; thus demonstrating that selection for lodging resistant genotypes can be done indirectly using the A001 marker.

The validation case studies described in this section show that although there are few examples in the public domain literature, nevertheless, where time and effort are invested, MAS can be an effective tool in public legume plant breeding programs, as indeed has long been appreciated 
and extensively utilized in the private seed sector. Thus, marker technology can assist the transfer of beneficial traits into otherwise elite genetic backgrounds, and can be used for the characterization and exploitation of biodiversity in gene banks. However, a number of difficulties remain for the development and application of molecular breeding technologies. Most critical is the need to develop better phenotypic evaluation methodologies for marker development. All too often, plant breeders use standard 1-5 or 1-9 scores during the marker development phase. Generally, such scoring systems are a good compromise for genetic progress in the context of conventional crop improvement. However, they are rarely the most appropriate methodology for the identification of marker-trait associations, particularly for traits with a complex genetic basis, low heritability, and high environmental interaction. For these traits, a more intensive phenotyping approach is required that provides highly quantitative data for component traits of the target character. In addition to generating accurate and precise phenotype data, it is equally important that field screening programs be based on multiple replications, locations, and seasons. Finally, there is a critical need for basing marker development on mapping population sizes substantially larger than those commonly used in academic situations, together with validation in multiple diverse populations (Young 1999).

For successful, large-scale, cost-effective MAS screening, there is generally a need for assay technology development that reduces the cost of DNA extraction and PCR, and, where possible, eliminates the need for data collection through electrophoresis. For example, there are several options for direct staining of DNA once allele-specific associated primers (ASAPs) have been identified that will specifically amplify only a DNA fragment tightly linked to one allele at a locus of interest ( $\mathrm{Gu}$ et al. 1995). Although once such a plus-minus assay is available, one must also develop multiplex controls for false negatives.

Recent developments in legume genomics are rapidly providing an array of molecular breeding opportunities to legume breeders. This includes the availability of a large number of robust PCR-based markers such as SSR, ESTs, and SNPs, the generation of high-density genetic maps, and the progress being made in sequencing the genomes of the two model legumes, M. truncatula and L. japonicus. At the same time, generic advances in automation technologies now offer real possibilities for the efficient development and application of marker-assisted selection techniques at a scale and unit cost that is finally of relevance to plant breeding programs and international germplasm collections. However, for the next magnitude increase in throughput and decrease in unit 
costs, we will have to look to micro-array technology to finally provide the required scale and cost for simultaneous selection of a diverse range of complex traits.

\section{CONCLUSIONS AND FUTURE PROSPECTS}

Resource-poor farmers across the developing world depend on grain legumes to sustain the health of their families and livestock, and to enhance their economic well-being. Invariably, they grow these crops under rain-fed low-input systems. These factors create a multiplicity of demands and stresses on these crops that can only be effectively addressed through holistic agricultural research and development programs that are now tasked with increasing productivity, yield stability, and profitability.

Traditional agricultural systems across the world have depended on the rotation of cereal and legume crops. However, with increasing intensification of agriculture during the twentieth century, there has been a substantial emphasis on cereals as the pre-eminent food commodity in national production and international trade. In turn, this has been reflected by a continuous and cumulative increase in funding for research and breeding of cereal crops (Goff and Salmeron 2004) that has resulted in the state-of-the-art in legumes falling further and further behind. Nevertheless, a renaissance is in sight thanks to the designation of two legume species as model genomes. Progress in the genomics of Medicago and Lotus offers the potential for real technological leapfrogging amongst legume crops.

Our newfound ability to dissect the genetics and biology of complex traits influencing the full range of agronomic characters is innately complementary and synergistic to ideotype breeding and should drive the long-awaited appearance of knowledge-led breeding systems. So-called 'molecular-enhanced plant breeding' will facilitate a new generation of seed-based products emerging from a much more target-orientated process both in terms of ecoregional adaptation and end-user preference. However, substantial advances in bioinformatics and whole plant physiology modeling will be required to enable the largely reductionist approaches of the genomics community to be effectively re-engineered into a meaningful crop plant. In addition, considerable increases in our knowledge and ability to positively manipulate genotype-byenvironment interaction and epistasis will be required to ensure that crop architecture performs as envisaged. The evolving science of simulating breeding systems is likely to be a tremendously important tool in 
this respect (Chapman et al. 2003; Wang et al. 2004c). Similarly, technologies that readily allow research scientists to work alongside plant breeders (Podlich et al. 2004) on real populations, grown in realistic environments (where possible in farmers' fields) using appropriate largescale experimental designs, will be increasingly critical. This will require breeders to augment and adjust their trait assessment profiles. Thus, in addition to scoring plant characteristics, breeders will need to assess agro-ecozone parameters such as water productivity and nutrient use efficiency. The critical issue here will be the development of systemic multidisciplinary and multi-sector teams that integrate researchers, growers, processors, traders, consumers, and other stakeholders. Only then will it be possible to effectively design holistic solutions to complex multifaceted problems that can be evaluated and refined early in the product development pathway. The increasing absence of academic (public sector) critical mass in this fundamentally important domain between research outputs and product development is surely one of the most pervasive reasons for insufficient impact in farmers' fields from investments in tropical plant science research and breeding. There is an urgent need for the academic community to value intellectual endeavour in this area and to populate it with some of the best minds in the field. Only then will we begin to see the promise of research for development again reaching the dramatic levels of impact realized during the green revolution.

Plant breeding during the twentieth century has been characterized by continuous incremental changes such as improvements in genetics and biometrics, plus more infrequent revolutionary changes including the automation of breeding trials and the computerization of phenotyping. In this context, the molecularization of plant breeding is a natural and inevitable next step. Beyond the increased potential power of selection, marker-assisted breeding offers additional advantages in the area of economics of scale both in terms of cost and time, as very different traits can be manipulated using the same technology. Most importantly, as with previous revolutionary changes, the integration of genomics will require a fundamental redesign of breeding systems in order to maximize the value of this new tool. Nowhere is this need more intense than in the effective merging of genetic resources, biotechnology, and pre-breeding strategies. Conventional approaches to identifying and utilizing genetic resources have tended to be highly inefficient. Genomics and bioinformatics now offer highly targeted mechanisms for providing plant breeders with structured and systematic entry points into vast global crop-related germplasm collections. Moreover, tools are emerging from these disciplines that will offer highly powerful approaches for rapid 
screening for target alleles, genes, and traits. However, again the promised impact will require radical changes in the design and implementation of trials, not least in the way traits are screened.

A number of model plant species have emerged that will each likely play a different role in the advancement of science and technology: Arabidopsis (metabolic pathways of fundamental importance to the functioning of plants), Medicago and Lotus (nitrogen fixation and other physiological processes of agronomic importance), and rice and maize (components of productivity, plus biotic and abiotic stresses important for yield stability). However, the extent to which genetic knowledge from model systems will be readily translated into economic impact in related crops remains to be empirically demonstrated (Thro et al. 2004). Dramatic progress in comparative mapping of cereals during the 1990s (Gale and Davos 1998) gave much impetus to an excessive focus on a few species based on the premise that advances in model systems could be directly translated into related crop species for immediate application and agronomic progress. More recently, there has been a shift to more gene-based (sequence) information and the ability to reverse engineer target traits into their genic components has become more routine. This has led to a partial re-evaluation of the comparative genomics doctrine, as unique gene level variation within the target crop has been assigned increasing importance (Doust et al. 2004). We must expect that the answers to many questions about crop productivity will be found in these crops and their related germplasm (Thro et al. 2004).

Recent studies show a strong correlation between the degree of synteny and phylogenetic distance in legumes. There appears to be a high level of conservation between Medicago and pea but the synteny with soybean is difficult to characterize (Choi et al. 2004a). In addition, genome size, ploidy, and structural reorganization are seen as significant confounding factors for the effective utilization of comparative genomics in molecular breeding. Moreover, as the whole genome sequence of rice opens up huge new possibilities for studying economic traits, it has also raised fundamental questions about the validity of current standard operating procedures. Most critically, it appears that the cross genera assignment of gene function deserves a more cautionary approach (Bennetzen et al. 2004). Functional validation of new genes within the species of interest is clearly becoming an essential component of the process. Conversely, different genes may be responsible for the same phenotype in different species (Havey 2004). Thus, some traits will require de novo research in the target crop or crop group. These types of findings will almost certainly lead to the emergence of a whole new generation of model crops, each valued for the intensive study of one or more specific trait(s) within their respective taxonomic clades: for exam- 
ple, pearl millet, cowpea, and cassava for drought tolerance; wheat, barley, and rice for disease resistance; and so forth. These studies will provide fundamentally important information for trait, gene, and allelemining of germplasm collections. However, it seems clear that there will be few major shortcuts or silver bullets. Instead, a continuous cumulative but iterative build-up of information from germplasm through breeding populations to new varieties will be required for consistent impact from unlocking crop-related genetic diversity.

Genomics research in legume crops and model systems will soon routinely define the location of loci controlling a target trait as well as identify underlying candidate genes and their sequences (through mapping, mutation, and transcriptional-based investigations). Based on this new knowledge, it will be possible to develop highly precise DNA markers for assisted-selection or aided-introgression. However, the efficacy of these markers will depend largely on the stringency of the marker development process and the tailoring of the breeding system. Where these criteria are fulfilled, we should expect to see new crop types with increased productivity, enhanced yield stability, and reduced input requirements. These new crops will have grossly altered architectures and/or physiological profiles. Yet, to see these advances have an impact beyond the experiments of crop physiologists, it will be necessary for the research and breeding community to adopt very different perspectives on their roles in product development, testing, refinement, and delivery. Most importantly, perhaps, the academic community must become more favourably inclined to publish negative results and inconsistencies that will allow the plant breeding community to more rapidly and efficiently identify and move ahead with best bet technologies and approaches.

\section{ACKNOWLEDGMENTS}

The authors wish to thank Rolf Folkertsma and Hari Sharma (ICRISAT) for their critical review of the manuscript, and three anonymous reviewers (Plant Breeding Reviews) for their extensive suggestions. We also thank the staff of ICRISAT library for their tireless efforts in conducting literature searches and arranging for reprints, and KDV Prasad for text editing, references, and tables as well help in obtaining rare publications. Sangam Dwivedi and Jonathan Crouch are partially funded by the Generation Challenge Program. Legume molecular breeding research at ICRISAT has benefited from substantial contributions from the Asian Development Bank, the Department for International Development, the European Union, and the Government of Japan. 


\section{LITERATURE CITED}

Acikgoz, N. 2001. Status of the European Lens database. p. 48-49. In: L. Magioni, M. Ambrose, R. Schachl, G. Duc, and E. Lipman (compilers), Report of a Working Group on Grain Legumes. Third Meeting, 5-7 July 2001, Krakow, Poland. IPGRI, Rome, Italy.

Acosta-Gallegos, J. A., C. Quintero, J. Vargas, O. Toro, J. Thome, and C. Cardona. 1998. A new variant of arcelin in wild common bean, Phaseolus vulgaris L., from southern Mexico. Genet. Resour. Crop Evol. 45:235-242.

Ae, N., J. Arihara, K. Okada, T. Yoshihara, and C. Johansen. 1990. Phosphorous uptake by pigeonpea and its role in cropping systems of the Indian subcontinent. Science 248: 477-480.

Ae, N., and R. F. Sen. 2002. Root cell-wall properties are proposed to contribute to phosphorous (P) mobilization by groundnut and pigeonpea. p. 123-131. In: J. J. Adu-Gyamfi (ed.), Food security in nutrient-stressed environments: exploiting plant genetic capabilities. Kluwer Academic Publishers, The Netherlands.

Aggarwal, V. D., and J. T. Ouedraogo. 1989. Estimation of cowpea yield loss from Striga infection. Trop. Agr. 66:91-92.

AGI. 2000. Analysis of the genome sequence of the flowering plant Arabidopsis thaliana. Nature 408:796-815.

Agrama, H., S. Houssin, and M. Tarek. 2002. Cloning of AFLP markers linked to resistance to Peronosclerospora sorghi in maize. Mol. Genet. Genom. 267:814-819.

Ahmad, M., A. G. Fautrier, D. L. McNeil, D. J. Burritt, and G. D. Hill. 1995. Attempt to overcome post-fertilization barrier in interspecific crosses of the genus Lens. Plant Breed. 114:558-560.

Ahmad, M., A. C. Russell, and D. L. McNeil. 1997. Identification and genetic characterization of different resistance sources to ascochyta blight within the genus Lens. Euphytica 97:311-315.

Ahmadi, N., L. Albar, G. Pressoir, A. Pinel, D. Fargette, and A. Ghesquiere. 1992. Genetic basis and mapping the resistance to rice yellow mottle virus. III. Analysis of QTL efficiency in introgressed progenies confirmed the hypothesis of complementary epistasis between two resistance QTLs. Theor. Appl. Genet. 103:1084-1092.

Ali, M., and S. Kumar. 2003. Chickpea research in India: an overview. p. 1-13. In: M. Ali, S. Kumar, and N. B. Singh (eds.), Chickpea research in India. Indian Institute of Pulses Research, Kanpur, India.

Ali, S. M., B. Sharma, and M. J. Ambrose. 1994a. Current status and future strategy in breeding pea to improve resistance to biotic and abiotic stresses. Euphytica 73:115-126.

Ali, S. M., B. Sharma, M. J. Ambrose, F. J. Muehlbauer, and W. J. Kaser. 1994b. Current status and future strategies in breeding pea to improve resistance to biotic and abiotic stresses. p. 540-558. In: F. J. Muehlbauer and W. J. Kaiser (eds.), Expanding the production and use of cool season food legumes. Kluwer Academic Publishers, Dordrecht, The Netherlands.

Alkharouf, N. W., and B. F. Matthews. 2004. SGMD: the soybean genomics and microarray database. Nucl. Acid Res. 32(Database issue):D398-D400.

Allkin, R., D. J. Goyder, F. A. Bisby, and R. J. White. 1986. Names and synonyms of species and subspecies in the Vicieae. Issue 3. Vicieae Database Project, Univ. Southampton, U.K.

Altshuler, D., V. J. Pollera, C. R. Cowles, W. J. Van Etten, J. Waldwin, L. Linton, and E. S. Lander. 2000. A SNP map of human genome generated by representation shot gun sequencing. Nature 407:513-516. 
Alzate-Marin, A. L., H. Menarim, J. M. Chagas, E. G. de Barros, and M. A. Moreira. 2000. Identification of a RAPD marker linked to the $\mathrm{Co}-6$ anthracnose resistant gene in common bean cultivar AB 136. Genet. Mol. Biol. 23:633-638.

Ambrose, M. 2001. Pisum progress report. p. 57-59. In: L. Magioni, M. Ambrose, R. Schachl, G. Duc, and E. Lipman (compilers), Report of a Working Group on Grain Legumes. Third Meeting, 5-7 July 2001, Krakow, Poland. IPGRI, Rome, Italy.

Amirul Islam, F. M., S. Beebe, M. Muñoz, J. Tohme, R. J. Redden, and K. E. Basford. 2004. Using molecular markers to assess the effect of introgression on quantitative attributes of common bean in the Andean gene pool. Theor. Appl. Genet. 108:243-252.

Ane, J.-M., J. Levy, P. Thoquet, O. Kulikova, F. de Billy, V. Penmetsa, D.-J. Kim, F. Debelle, C. Rosenberg, D. R. Cook, T. Bisseling, T. Huguet, and J. Denarie. 2002. Genetic and cytogenetic mapping of DMI1, DMI2, and DMI3 genes of Medicago truncatula involved in Nod factor transduction, nodulation, and mycorrhization. Mol. Plant Microbe Interact. 15:1108-1118.

Angelova, S. 2001. Maintenance, enrichment and preservation of grain legume collections in Bulgaria. p. 69-73. In: L. Magioni, M. Ambrose, R. Schachl, G. Duc, and E. Lipman (compilers), Report of a Working Group on Grain Legumes. Third Meeting, 5-7 July 2001, Krakow, Poland. IPGRI, Rome, Italy.

Anonymous. 2003. Special legume issue. Plant Physiology 131(3): This issue contains many interesting papers on model legumes, legume phylogeny, genetic transformation, utilization, nutritional quality, natural products, and genomics.

Aragao, F. J. L., L. M. G. Barros, M. V. de Sousa, M. F. G. de Sa, E. R. P. Almeida, E. S. Gander, and E. L. Rech. 1999. Expression of methionine-rich storage albumin from the Brazilian nut (Bertholletia excelsa H.B.K., Lecythidaceae) in transgenic bean plants (Phaseolus vulgaris L., Fabaceae). Genet. Mol. Biol. 22:445-449.

Arimura, G.-I., R. Ozawa, S. Kugimiya, J. Takabayashi, and J. Bohlman. 2004. Herbivoreinduced defence response in a model legume. Two-spotted spider mites induce emission of (E)- $\beta$-Ocimene and transcript accumulation of (E)- $\beta$-Ocimene synthase in Lotus japonicus. Plant Physiol. 135:1976-1983.

Ariyarathne, H. M., D. P. Coyne, G. Jung, P. W. Skroch, A. K. Vidaver, J. R. Steadman, P. N. Miklas, and M. J. Bassett. 1999. Molecular mapping of disease resistance genes for halo blight, common bacterial blight, and bean common mosaic virus in a segregating population of common bean. J. Am. Soc. Hort. Sci. 124:654-662.

Arnaud-Santana, E., D. P. Coyne, K. M. Eskridge, and A. K. Vidaver. 1994. Inheritance, low correlations of leaf, pod and seed reactions to common blight disease in common beans, and implications for selection. J. Am. Soc. Hort. Sci. 119:116-121.

Arondel, V., B. Lemieux, I. Hwang, S. Gibson, H. M. Goodman, and C. R. Somerville. 1992. Map-based cloning of a gene controlling Omega-3 fatty acid desaturation in Arabidopsis. Science 258:1353-1355.

Arumuganathan, K., and E. D. Earle. 1991. Nuclear DNA content of some important plant species. Plant Mol. Biol. Rep. 9:208-219.

Asamizu, E., T. Kato, S. Sato, Y. Nakamura, T. Kaneko, and S. Tabata. 2003. Structural analysis of a Lotus japonicus genome. IV. Sequence features and mapping of seventythree TAC clones which cover the 7.5 Mb regions of the genome. DNA Res. 10:115-122.

Asamizu, E., Y. Nakamura, S. Sato, and S. Tabata. 2000. Generation of 70137 non-redundant expressed sequence tags from a legume, Lotus japonicus. DNA Res. 7:127-130.

Avila, C. M., J. C. Sillero, D. Rubiales, M. T. Moreno, and A. M. Torres. 2003. Identification of RAPD markers linked to the $U v f-1$ gene conferring hypersensitive resistance against rust (Uromyces viciae-fabae) in Vicia faba L. Theor. Appl. Genet. 107:353-358. 
Babu, C. R., S. K. Sharma, S. R. Chaterjee, and Y. P. Abrol. 1988. Seed protein and amino acid composition of wild Vigna radiata var. sublobata (Fabaceae) and two cultigens, $V$. mungo and $V$. radiata. Econ. Bot. 42:54-61.

Bai, Y., T. E. Michaels, and K. P. Pauls. 1997. Identification of RAPD markers linked to common bacterial blight resistance genes in Phaseolus vulgaris L. Genome 40:544-551.

Bajaj, S., J. Targolli, L. F. Liu, T. H. D. Ho, and R. Wu. 1999. Transgenic approach to increase dehydration-stress tolerance in plants. Mol. Breed. 5:493-503.

Baquerizo-Audiot, E., B. Desplanque, J. M. Prosperi, and S. Santoni. 2001. Characterization of microsatellite loci in the diploid legume Medicago truncatula (barrel medic). Mol. Ecol. Notes 1:1-2.

Barker, D. G., S. Bianchi, F. London, Y. Dattee, G. Duc, S. Essad, P. Flament, P. Gallusci, G. Genier, P. Guy, X. Muel, J. Tourneur, J. Denarie, and T. Huguet. 1990. Medicago truncatula, a model plant for studying the molecular genetics of the Rhizobium-legume symbiosis. Plant Mol. Biol. 8:40-49.

Barulina, E. I. 1930. Lentils of USSR and other countries; a botanico agronomical monograph. Trudy Prikl. Bot. Genet. Selek. Suppl. 40:265-319.

Bassett, M. J. 1996. List of genes-Phaseolus vulgaris L. Annu. Rep. Bean Improv. Coop. 12:13-15.

Bayaa, B., W. Erskine, and A. Hamdi. 1995. Evaluation of wild lentil collection for resistance to vascular wilt. Genet. Resour. Crop Evol. 42:231-235.

Bayuelo-Jimenez, J. S., D. G. Debouck, and J. P. Lynch. 2002. Salinity tolerance in Phaseolus species during early vegetative growth. Crop Sci. 42:2184-2192.

Beaver, J. S., J. C. Rosas, J. Myers, J. Acosta, J. D. Kelly, S. Nchimbi-Msolla, R. Misangu, J. Bokosi, S. Temple, E. Arnaud-Santana, and D. P. Coyne. 2003. Contributions of the Bean/Cowpea CRSP to cultivar and germplasm development in common bean. Field Crops Res. 82:87-102.

Beebe, S., C. Cardona, O. Díaz, F. Rodríguez, E. Mancia, and S. Ajquejay. 1993. Development of common bean (Phaseolus vulgaris L.) lines resistant to the bean pod weevil, Apion godmani Wagner, in Central America. Euphytica 69:83-88.

Beebe, S., P. W. Skroch, J. Tohme, M. C. Duque, F. Pedraza, and J. Nienhuis. 2000. Structure of genetic diversity among common bean land races of Middle American origin based on correspondence analysis of RAPD. Crop Sci. 40:264-273.

Beebe, S. E. 1989. Quantitative genetics in Phaseolus vulgaris: the example of resistance to Xanthomonas campestris pv. Phaseoli. p. 213-238. In: S. Beebe (ed.), Current topics in breeding of common bean. Proc. Int. Bean Breed. Workshop Working Doc. 47, CIAT, Cali.

Beebe, S. P., I. Ochoa, P. Skroch, J. Nienhuis, and J. Tivang. 1995. Genetic diversity among common bean breeding lines developed for Central America. Crop Sci. 35:1178-1183.

Beer, S. C., W. Siripoonwiwat, L. S. O’Donoughue, E. Souza, D. Matthews, and M. E. Sorrells. 1997. Association between molecular markers and quantitative traits in an oat germplasm pool: Can we infer linkages. J. Agr. Genomics 3. [online] URL:http:// www.ncgr.org/research/jag/papers97/paper197/indexp197.html.

Bell, E. A. 1964. Relevance of biochemical taxonomy to the problem of lathyrism. Nature 203:378-380.

Benko-Iseppon, A.-M., P. Winter, B. Huettel, C. Staginnus, F. J. Muehlbauer, and G. Kahl. 2003. Molecular markers closely linked to fusarium resistance genes in chickpea show significant alignments to pathogenesis-related genes located on Arabidopsis chromosomes 1 and 5. Theor. Appl. Genet. 107:379-386.

Bennett, M. D., and I. J. Leitch. 2003. Plant DNA C-values database (release 2.0, Jan. 2003) http://www.rbgkew.org.uk/cval/homepage.html. 
Bennetzen, J. L. 2000. Comparative sequence analysis of plant nuclear genomes: Microcolinearity and its many exceptions. Plant Cell 12:1021-1029.

Bennetzen, J. L., C. Coleman, R. Liu, J. Ma, and W. Ramakrishna. 2004. Consistent overestimation of gene number in complex plant genomes. Curr. Opin. Plant Biol. 7: $732-736$.

Bertioli, D. J., S. C. Leal-Bertioli, M. B. Lion, V. L. Santos, G. Pappas Jr., S. B. Cannon, and P. M. Guimaraes. 2003. A large-scale analysis of resistance gene homologues in Arachis. Mol. Genet. Genom. 270:34-45.

Bestel-Corre, G., E. Dumas-Gaudot, V. Poinsot, M. Dieu, J. F. Dierick, T. R. J. van, V. Gianinazzi-Pearson, and S. Gianinazzi. 2002. Proteome analysis and identification of symbioses-related proteins from Medicago truncatula Gaertn. by two dimensional electrophoresis and mass spectrometry. Electrophoresis 23:122-137.

Bisht, I. S., R. K. Mahajan, and D. P. Patel. 1998. The use of characterization data to establish the Indian mungbean core collection and assessment of genetic diversity. Genet. Resour. Crop Evol. 45:127-133.

Blair, M. W., F. Pedraza, H. F. Buendia, E. Gaitan-Solis, S. E. Beebe, P. Gepts, and J. Tohme. 2003. Development of a genome-wide anchored microsatellite map for common bean (Phaseolus vulgaris L.). Theor. Appl. Genet. 107:1362-1374.

Boerma, H. R., and J. E. Specht (eds.). 2004. Soybeans: Improvement, production, and uses. American Society Agronomy, Agronomy Monograph 16 (third edition). pp. 1,180.

Bohnert, H. J., P. Ayoubi, C. Borchert, R. A. Bressan, R. L. Burnap, J. C. Cushman, M. A. Cushman, M. Deyholos, R. Fisher, D. W. Galbraith, P. M. Hasegawa, M. Jenks, S. Kawasaki, H. Koiwa, S. Kore-eda, B.-H. Lee, C. B. Michalowski, E. Misawa, M. Nomura, N. Oztuk, B. Postier, R. Prade, C.-P. Song, Y. Tanaka, H. Wang, and J.-K. Zhu. 2001. A genomics approach towards salt stress tolerance. Plant Physiol. Biochem. 39:295-311.

Bond, D. A., G. J. Jellis, G. G. Rowland, J. L. Guen, L. D. Robertson, S. A. Khalil, and L. LiJuan. 1994. Present status and future strategy in breeding faba beans (Vicia faba L.) for resistance to biotic and abiotic stresses. Euphytica 73:151-166.

Boreck, I. B., and B. K. Suarez. 2001. Linkage and association: basic concepts. Adv. Genet. 42:45-66.

Borisov, A. Y., L. H. Madsen, V. E. Tsyganov, Y. Umehara, V. A. Voroshilova, A. O. Batagov, N. Sandal, A. Mortensen, L. Schauser, N. Ellis, I. A. Tikhonovich, and J. Stougaard. 2003. The Sym35 gene required for root nodule development in pea is an ortholog of Nin from Lotus japonicus. Plant Physiol. 131:1009-1017.

Borrell, A. K., G. L. Hammer, and E. Oosterom. 2001. Stay green: a consequence of the balance between supply and demand for nitrogen during grain filling? Ann. Appl. Biol. 138:91-95.

Boukar, O., L. Kong, B. B. Singh, L. Murdock, and H. W. Ohm. 2004. AFLP and AFLPderived SCAR markers associated with Striga gesnerioides resistance in cowpea. Crop Sci. 44:1259-1264.

Boutin, S. R., N. D. Young, T. C. Olson, Z.-H. Yu, R. C. Shoemaker, and C. E. Vallejos. 1995. Genome conservation among three legume genera detected with DNA markers. Genome 38:928-937.

Bradley, C. A., G. L. Hartman, L. M. Wax, and W. L. Pedersen. 2002. Quality of harvested seeds associated with soybean cultivars and herbicides under weed-free conditions. Plant Dis. 86:1036-1042.

Bretting, P. K., and M. P. Widrlechner. 1995. Genetic markers and plant genetic resource management. Plant Breed. Rev. 31:11-86.

Broughton, W. J., G. Hernandez, M. Blair, S. Beebe, P. Gepts, and J. Vanderleyden. 2003. Beans (Phaseolus spp.)—model food legumes. Plant Soil 252:55-128. 
Brown, A. H. D. 1989. Core collections: a practical approach to genetic resources management. Genome 31:818-824.

Brown, S. M., and S. Kresovich. 1996. Molecular characterization for plant genetic resources conservation. p. 85-93. In: A. H. Paterson (ed.), Genome mapping of plants. Academic Press, San Diego.

Brugmans, B., R. G. M. van der Hulst, R. G. F. Visser, P. Lindhout, and H. J. van Eck. 2003. A new and versatile method for the successful conversion of AFLP markers into simple single locus markers. Nucl. Acid Res. 31:10-55.

Brummer, E. C., G. L. Graef, J. Orf, J. R. Wilcox, and R. C. Shoemaker. 1997. Mapping QTL for seed protein and oil content in eight soybean populations. Crop Sci. 37:370-378.

Buckler, E. S., and J. M. Thornsberry. 2002. Plant molecular diversity and applications to genomics. Curr. Opin. Plant Biol. 5:107-111.

Burleigh, S. H., T. Cavagnaro, and I. Jakobsen. 2002. Functional diversity of arbuscular mycorrhizas extends to the expression of plant genes involved in plant nutrition. J. Expt. Bot. 53:1593-1601.

Burns, M. J., K. J. Edwards, H. J. Newbury, B. V. Ford-Lloyd, and C. D. Baggott. 2001. Development of simple sequence repeat (SSR) markers for the assessment of gene flow and genetic diversity in pigeonpea (Cajanus cajan). Mol. Ecol. Notes 1:283-285.

Burow, M. D., C. E. Simpson, J. L. Starr, and A. H. Paterson. 2001. Transmission genetics of chromatin from a synthetic amphiploid in cultivated peanut (A. hypogaea L.): Broadening the gene pool of a monophyletic polyploid species. Genetics 159:823-837.

Burr, B., F. A. Burr, K. H. Thompson, M. C. Albertson, and C. W. Stubber. 1988. Gene mapping with recombinant inbreds in maize. Genetics 118:519-526.

Burr, B., S. V. Evola, F. A. Burr, and J. S. Beckmann. 1983. The application of restriction fragment length polymorphism to plant breeding. p. 45-49. In: J. K. Setlow and A. Hollaender (eds.), Genetic engineering. Vol. 5. Plenum Press, New York.

Burridge, J. A., and T. Hymowitz. 1997. Management of USDA wild perennial Glycine collection. Soybean Genet. Newsl. 24:123-124.

Burstin, J., G. Deniot, J. Potier, C. Weinachter, G. Aubert, and A. Baranger. 2001. Microsatellite polymorphism in Pisum sativum. Plant Breed. 120:311-317.

Burton, J. W. 1997. Soybean (Glycine max (L.) Merr.). Field Crops Res. 53:171-186.

Caetano-Anolles, G., and P. M. Gresshoff. 1991. Plant genetic control of nodulation. Annu. Rev. Microbe. 45:345-382.

Cahill, D. 2000. High throughput marker assisted selection. Proc. 8th Biennial Conference on the Cellular and Molecular Biology of the Soybean. Lexington, KY.

Caixeta, E. T., A. Borem, S. A. Fagundes, S. Niestche, E. G. de Barros, and M. A. Moreira. 2003. Inheritance of angular leaf spot resistance in common bean line BAT 332 and identification of RAPD markers linked to the resistance gene. Euphytica 134:297-303.

Campbell, C. G., R. B. Mehra, S. K. Agrawal, Y. Z. Chen, A. M. Abd El Moneim, H. I. T. Khawaja, C. R. Yadav, J. U. Tay, and W. A. Araya. 1994. Current status and future strategy in breeding grasspea (Lathyrus sativus). Euphytica 73:167-175.

Cannon, S. B., W. R. McCombe, S. Sato, S. Tabata, R. Denny, L. Palmer, M. Katari, N. D. Young, and G. Stacey. 2003. Evolution and microsynteny of the apyrase gene family in three legume genomes. Theor. Appl. Genet. 270:347-361.

Cannon, S. B., H. Y. Zhu, A. Baumgarten, R. Sprangler, G. May, D. R. Cook, and N. D. Young. 2002. Diversity, distribution and ancient taxonomic relationships within the TIR and non-TIR NBS-LRR resistance gene subfamilies. J. Mol. Evol. 54:548-562.

Capell, T., L. Bassie, and P. Christou. 2004. Modulation of the polyamine biosynthetic pathway in transgenic rice confers tolerance to drought stress. Proc. Nat. Acad. Sci. USA 101:9909-9914. 
Capell, T., C. Escobar, H. Lui, D. Burtin, O. Lepri, and P. Christou. 1998. Over-expression of the oat argentine decarboxylase cDNA in transgenic rice (Oryza sativa L.) affects normal development patterns in vitro and results in putrescine accumulation in transgenic plants. Theor. Appl. Genet. 97:246-254.

Caranta, C., A. Thabuis, and A. Palloix. 1999. Development of a CAPS marker for the Pvr4 locus: A tool for pyramiding potyvirus resistance genes in pepper. Genome 42:1111-1116.

Caviness, C. E. 1992. Breeding for resistance to cyst nematode. p. 143-156. In: R. D. Riggs and J. A. Wrather (eds.), Biology and management of the soybean cyst nematode. APS Press, St. Paul, MN.

Chabaud, M., C. Larsonnaud, C. Marmouget, and T. Huguet. 1996. Transformation of Barrel Medic (Medicago truncatula Gaertn.) by Agrobacterium tumefaciens and regeneration via somatic embryogenesis of transgenic plants with the MtENOD12 nodulin promoter fused to the GUS reporter gene. Plant Cell Rep. 15:305-310.

Chaitieng, B., A. Kaga, O. K. Han, X. W. Wang, S. Wongkaew, P. Laosuwan, N. Tomooka, and D. A. Vaughan. 2002. Mapping a new source of resistance to powdery mildew in mungbean. Plant Breed. 121:521-525.

Chandel, K. P. S., R. N. Lester, and R. J. Starling. 1984. The wild ancestor of urid and mungbeans (V. mungo (L) Hepper and V. radiata (L.) Wilczek). Bot. J. Linn. Soc. 89:85-86.

Chandra, A., and D. Pental. 2003. Regeneration and genetic transformation of grain legumes. Curr. Sci. 84:381-387.

Chang, C. C., J. L. Bowman, A. W. DeJohn, E. S. Lander, and E. M. Meyerowitz. 1988. Restriction fragment length polymorphism linkage map for Arabidopsis thaliana. Proc. Nat. Acad. Sci. (USA) 85:6856-6860.

Chang, Y.-L., Q. Tao, C. Scheuring, K. Ding, K. Meksem, and H.-B. Zhang. 2001. An integrated map of Arabidopsis thaliana for functional analysis of its genome sequence. Genetics 159:1231-1242.

Chapman, S. C., M. Cooper, D. W. Podlich, and G. L. Hammer. 2003. Evaluating plant breeding strategies by simulating gene action and dryland environment effects. Agron. J. 95:99-113.

Chapman, S. C., G. L. Hammer, D. W. Podlich, and M. Cooper. 2002. Linking biophysical and genetic models to integrate physiology, molecular biology and plant breeding. p. 167-187. In: M. S. Kang (ed.), Quantitative genetics, genomics and plant breeding. CABI, Wallingford, UK.

Chatterjee, B. N., and S. Dana. 1997. Rice bean (Vigna umbellata (Thumb) Ohwi and Ohashi). Trop. Grain Legume Bull. 10:22-25.

Chee, M., R. Yang, E. Hubbell, A. Berno, X. C. Huang, D. Stern, J. Winkler, D. J. Lockhart, M. S. Morris, and S. P. A. Fodor. 1996. Accessing genetic information with high-density DNA arrays. Science 274:610-614.

Chen, F., and P. M. Hays. 1989. A comparison of Hordeum bulbosum-mediated haploid production efficiency in barley using in vitro floret and tiller culture. Theor. Appl. Genet. 77:701-704.

Chen, H. K., M. C. Mok, S. Shanmugasundaram, and D. W. S. Mok. 1989. Interspecific hybridization between Vigna radiata (L.) Wilczek and V. glabrescens. Theor. Appl. Genet. 78:641-647.

Chen, M., G. Presting, W. B. Barbazuk, J. L. Goicoechea, B. Blackmon, G. Fang, H. Kim, D. Frisch, Y. Yu, S. Sun, S. Higingbottom, J. Phimphilai, D. Phimphilai, S. Thurmond, B. Gaudette, P. Li, J. Liu, J. Hatfield, D. Main, K. Farrar, C. Henderson, L. Barnett, R. Costa, B. Williams, S. Walser, M. Atkins, C. Hall, M. A. Budiman, J. P. Tomkins, M. Luo, I. Bancroft, J. Salse, F. Regad, T. Mohapatra, N. K. Singh, A. K. Tyagi, C. Soderlund, 
R. A. Dean, and R. A. Wing. 2002. An integrated physical and genetic map of the rice genome. Plant Cell 14:537-545.

Chen, S., X. H. Lin, C. G. Xu, and Q. Zhang. 2000. Improvement of bacterial blight resistance of 'Minghui 63', an elite restorer line of hybrid rice, by molecular marker-assisted selection. Crop Sci. 40:239-244.

Cheng, S. S., M. J. Bassett, and K. H. Quesenberry. 1981. Cytogenetic analysis of interspecific hybrids between common bean and scarlet runner bean. Crop Sci. 21:75-79.

Chida, Y., K. Okazaki, A. Karasawa, K. Akashi, Y. Nakazawa-Nas, S. Hase, H. Takahashi, and Y. Ehara. 2000. Isolation of molecular markers linked to the Cry locus conferring resistance to cucumber mosaic cucumovirus infection in cowpea. J. Gen. Plant Pathol. 66:242-250.

Cho, R. J., M. Mindrinos, D. R. Richards, R. J. Sapolsky, M. Anderson, E. Drenkard, J. Dewdney, T. L. Reuber, M. Stammers, N. Federspiel, A. Theologis, W.-H. Yang, E. Hubell, M. Au, E. Y. Chung, D. Leshkari, B. Lemieux, C. Dean, R. J. Lipshutz, F. M. Ausubel, R. W. Davis, and P. J. Oefner. 1999. Genome-wide mapping with biallelic markers in Arabidopsis thaliana. Nature Genet. 23:203-207.

Cho, S., J. Kumar, J. L. Schultz, K. Anupama, F. Tefera, and F. J. Muehlbauer. 2002. Mapping genes for double podding and other morphological traits in chickpea. Euphytica 128:285-292.

Choi, H.-K., J.-H. Mun, D.-J. Kim, H. Zhu, J.-M. Baek, J. Mudge, B. Roe, N. Ellis, J. Doyle, G. B. Kiss, N. D. Young, and D. R. Cook. 2004a. Estimating genome conservation between crop and model legume species. Proc. Nat. Acad. Sci. 101:15289-15294.

Choi, H.-K., D. Kim, T. Uhm, E. Limpens, H. Lim, J.-H. Mun, P. Kalo, R. V. Penmetsa, A. Seres, O. Kulikova, B. A. Roe, T. Bisseling, G. B. Kiss, and D. R. Cook. 2004c. A sequenced-based genetic map of Medicago truncatula and comparison of marker colinearity with M. sativa. Genetics 166:1463-1502.

Choi, I.-Y., D. Hyten, and P. Cregan. 2004b. SNP discovery in legume species using primers derived from soybean unigenes. PAG (abstr.).

Chowdhury, M. A., C. P. Andrahennadi, A. E. Slinkard, and A. Vandenberg. 2001. RAPD and SCAR markers for resistance to Ascochyta blight in lentil. Euphytica 118:331337.

Chowdhury, M. A., and A. E. Slinkard. 1999. Linkage of random amplified polymorphic DNA, isozyme and morphological markers in grasspea (Lathyrus sativus). J. Agr. Sci. 133:389-395.

Chung, J., H. L. Babka, G. L. Graef, P. E. Staswick, D. J. Lee, P. B. Cregan, R. C. Shoemaker, and J. E. Specht. 2003. The seed protein, oil, and yield QTL on soybean linkage group 1. Crop Sci. 43:1053-1067.

Clement, S. L., D. C. Hardie, and L. R. Elberson. 2002. Variation among accessions of Pisum fulvum for resistance to pea weevil. Crop Sci. 42:2167-2173.

Colebatch, G., S. Kloska, B. Trevaskis, S. Freund, T. Altman, and M. Udvardi. 2002. Novel aspects of symbiotic nitrogen fixation uncovered by transcript profiling with cDNA arrays. Mol. Plant Microbe Interact. 15:411-420.

Concibido, V. C., R. L. Denny, S. R. Boutin, R. Hautea, J. H. Orf, and N. D. Young. 1994. DNA marker analysis of loci underlying resistance to soybean cyst nematode (Heterodera glycines Ichinohe). Crop Sci. 34:240-246.

Concibido, V. C., R. L. Denny, D. A. Lange, J. H. Orf, and N. D. Young. 1996. RFLP mapping and marker-assisted selection of soybean cyst nematode resistance in PI 209332. Crop Sci. 36:1643-1650.

Concibido, V. C., B. W. Diers, and P. R. Arelli. 2004. A decade of QTL mapping for cyst nematode resistance in soybean. Crop Sci. 44:1121-1131. 
Concibido, V. C., D. A. Lange, R. L. Denny, J. H. Orf, and N. D. Young. 1997. Genome mapping of soybean cyst nematode resistance gene in 'Peking', PI 90763, and PI 88788 using DNA markers. Crop Sci. 37:258-264.

Concibido, V., B. Le Vallee, P. Mclaird, N. Pineda, J. Meyer, L. Hummel, J. Yang, K. Wu, and X. Delannay. 2003. Introgression of a quantitative trait locus for yield from Glycine soja into commercial soybean cultivars. Theor. Appl. Genet. 106:575-582.

Cook, D. R. 2004. Unraveling the mystery of Nod factor signaling by a genomic approach in Medicago truncatula. Proc. Nat. Acad. Sci. 101:4339-4340.

Cook, D. R., K. A. VandenBosch, F. J. de Bruijin, and T. Huguet. 1997. Model legumes get the nod. Plant Cell 9:275-281.

Cooper, D. C., and R. A. Brink. 1940. Somatoplastic sterility as a cause of seed failure after interspecific hybridization. Genetics 25:593-617.

Cooper, M., S. C. Chapman, D. W. Podlich, and G. L. Hammer. 2002. The GP problem: quantifying gene-to-phenotype relationships. In Silico Biol. 2:151-164.

Cordero, C., and Z. Skinner. 2002. Isolation from alfalfa of resistance gene analogues containing nucleotide-binding sites. Theor. Appl. Genet. 104:1283-1289.

Correa, R. X., M. R. Costa, P. I. Good-God, V. A. Ragagnin, F. G. Faleiro, M. A. Moreira, and E. G. de Barros. 2000. Sequence characterized amplified regions linked to rust resistance gene in common bean. Crop Sci. 40:804-807.

Coryell, V. H., H. Jessen, J. M. Schupp, D. Webb, and P. Keim. 1999. Allele specific hybridization markers for soybean. Theor. Appl. Genet. 98:690-696.

Covitz, P. A., L. S. Smith, and S. R. Long. 1998. Expressed sequence tags from a root-hairenriched Medicago truncatula cDNA library. Plant Physiol. 117:1325-1332.

Coyne, C. J., K. Meksem, D. A. Lightfoot, K. E. Keller, R. R. Martin, M. T. McClendon, D. A. Inglis, E. W. Storlie, and K. E. McPhee. 2000. Construction of bacterial artificial chromosome library for pea (Pisum sativum L.). Pisum Genet. 32:23-26.

Coyne, D. P., J. R. Steadman, G. Godoy-Lutz, R. Gilbertson, E. Arnaud-Santana, J. S. Beaver, and J. R. Myers. 2003. Contributions of the bean/cowpea CRSP to management of bean diseases. Field Crops Res. 82:155-168.

Cregan, P. B., T. Jarvik, A. L. Bush, R. C. Shoemaker, K. G. Lark, A. L. Kahler, N. Kaya, T. T. VanToai, D. G. Lohnes, J. Chung, and J. E. Specht. 1999a. An integrated genetic linkage map of the soybean genome. Crop Sci. 39:1464-1490.

Cregan, P. B., J. Mudge, E. W. Fickus, D. Danesh, R. Denny, and N. D. Young. 1999b. Two simple sequence repeat markers to select for soybean cyst nematode resistance conditioned by the rhg1 locus. Theor. Appl. Genet. 99:811-818.

Cregan, P. B., J. Mudge, E. W. Fickus, L. F. Mareck, D. Danesh, R. Denny, R. C. Shoemaker, B. F. Matthews, T. Jarvik, and N. D. Young. 1999. Targeted isolation of simple sequence repeat markers through the use of bacterial artificial chromosomes. Theor. Appl. Genet. 98:919-928.

Croft, A. M., E. C. K. Pang, and P. W. J. Taylor. 1999. Molecular analysis of Lathyrus sativus L. (grasspea) and related Lathyrus species. Euphytica 107:167-196.

Croser, J. S., F. Ahmad, H. J. Clark, and K. H. M. Siddique. 2003. Utilization of wild Cicer in chickpea improvement-progress, constraints, and prospects. Australian J. Agr. Res. $54: 429-444$.

Crouch, H. K., J. H. Crouch, S. Madsen, D. R. Vuylsteke, and R. Ortiz. 2000. Comparative analysis of phenotypic and genotypic diversity among plantain landraces (Musa spp., AAB group). Theor. Appl. Genet. 101:1056-1065.

Crouch, J. H., H. K. Buhariwalla, M. Blair, E. Mace, B. Jayashree, and R. Serraj. 2004. Biotechnological-based contributions to enhancing legume productivity in resourcepoor areas. p. 47-65. In: R. Serraj (ed.), Symbiotic nitrogen fixation: Prospects for 
enhanced application in tropical agriculture. Oxford and IBH Publ. Co. Pvt. Ltd., New Delhi.

Dangl, J. L., and J. D. G. Jones. 2001. Plant pathogens and integrated defence responses to infection. Nature 411:826-833.

de Arruda, M. C. C., A. L. Alzate-Marin, J. M. Chagas, M. A. Moreira, and E. G. de Barros. 2000. Identification of random amplified polymorphic DNA markers linked to the Co4 resistance gene to Colletotrichum lindemuthianum in common bean. Phytopathology 90:758-761.

Debouck, D. G. 1991. Systematics and morphology. p. 55-118. In: A. V. Schoonhoven and O. Voysest (eds.), Common beans: Research for improvement. CIAT, Cali, Colombia.

Debouck, D. G. 1999. Diversity in Phaseolus species in relation to the common bean. p. 25-52. In: S. P. Singh (ed.), Common bean improvement in the twenty-first century. Kluwer, Dordrecht, The Netherlands.

Desprez, T., J. Amselem, M. Caboche, and H. Hofte. 1998. Differential gene expression in Arabidopsis monitored using cDNA arrays. Plant J. 14:643-652.

Devos, K. M., and M. D. Gale. 1997. Comparative genetics in the grasses. Plant Mol. Biol. 35:3-15.

Dhaubhadel, S., B. D. McGarvey, R. Williams, and M. Gijzen. 2003. Isoflavonoid biosynthesis and accumulation in developing soybean seeds. Plant Mol. Biol. 53:733-743.

Dillmann, C., A. Bar-Hen, D. Guerin, A. Charcosset, and A. Murigneux. 1997. Comparison of RFLP and morphological distances between maize Zea Mays L. inbred lines. Consequences for germplasm protection purposes. Theor. Appl. Genet. 95:92-102.

Dirlewanger, E., P. G. Isaac, S. Ranade, M. Belajouza, R. Cousing, and D. de Vienne. 1994. Restriction fragment length polymorphism analysis of loci associated with disease resistance gene and developmental traits in Pisum sativum L. Theor. Appl. Genet. $88: 17-27$.

Dixon, R. A., and C. L. Steele. 1999. Flavonoids and isoflavonoids-A gold mine for metabolic engineering. Trends Plant Sci. 4:394-400.

Doku, E. V. 1969. Growth habit and pod production in Bambara groundnut (Voandzeia subterranean). Ghana J. Agr. Sci. 2:91-95.

Donson, J., Y. Fang, G. Espiritu-Santo, W. Xing, A. Salazar, S. Miyamoto, V. Armendarez, and W. Volkmuth. 2002. Comprehensive gene expression analysis by transcript profiling. Plant Mol. Biol. 48:75-97.

Doust, A. N., K. M. Devos, M. D. Gadberry, M. D. Gale, and E. A. Kellogg. 2004. Genetic control of branching in foxtail millet. Proc. Nat. Acad. Sci. 101:9045-9050.

Downey, R. K., and D. C. Taylor. 1996. Diversification of canola/rapeseed fatty acid supply for the year 2000. Oléagineux Corps Gras Lipides 3:9-13.

Doyle, J. J., J. A. Chappill, C. D. Bailey, and T. Kajita. 2000. Towards a comprehensive phylogeny of legumes: evidences from $r b c L$ sequences and nonmolecular data. p. 1-20. In: P. Herendeen and A. Bruneau (eds.), Advances in legume systematics, Part 9. Royal Botanic Gardens, Kew, UK.

Doyle, J. J., J. L. Doyle, J. A. Ballenger, and J. D. Palmer. 1996. The distribution and phylogenetic significance of a $50 \mathrm{~kb}$ chloroplast DNA inversion in the flowering plant family Leguminosae. Mol. Phylogenet. Evol. 5:531-541.

Doyle, J. J., J. L. Doyle, J. T. Rauscher, and A. H. D. Brown. 2004. Evolution of the perennial soybean polyploid complex (Glycine subgenus Glycine): a study of contrast. Biol. J. Linnean Soc. 82:583-597.

Doyle, J. J., and M. A. Luckow. 2003. The rest of the iceberg. Legume diversity and evolution in a phylogenetic context. Plant Physiol. 131:900-910. 
Drenkard, E., B. G. Richter, S. Rozen, L. M. Stutius, N. A. Angell, M. Mindrinos, R. J. Cho, P. J. Oefner, R. W. Davis, and F. M. Ausubel. 2000. A simple procedure for the analysis of single nucleotide polymorphisms facilitates map-based cloning in Arabidopsis. Plant Physiol. 124:1483-1492.

Dubouzet, J. G., Y. Sakuma, Y. Ito, M. Kasuga, E. G. Dubouzet, S. Miura, M. Seki, K. Shinozaki, and K. Yamaguchi-Shinozaki. 2003. OsDREB genes in rice, Oryza sativa L., encode transcription activators that function in drought-, high-salt- and cold-responsive gene expression. The Plant J. 33:751-763.

Duc, G., P. Marget, and F. Moussy. 2001. The European Vicia faba database. p. 42-44. In: L. Magioni, M. Ambrose, R. Schachl, G. Duc, and E. Lipman (compilers), Report of a Working Group on Grain Legumes. Third Meeting, 5-7 July 2001, Krakow, Poland. IPGRI, Rome, Italy.

Duggan, D. J., M. Bitnner, Y. Chen, P. Meltzer, and J. M. Trent. 1999. Expression profiling using cDNA microarrays. Nat. Genet. 21:10-14.

Dunwell, J. M. 1998. Novel food products from genetically modified crop plants: methods and future prospects. Int. J. Food Sci. Technol. 33:205-213.

Duran, Y., R. Fratini, P. Garcia, and M. Perez de la Vega. 2004. An intersubspecific genetic linkage map of lens. Theor. Appl. Genet. 108:1265-1273.

Duranti, M., and C. Gius. 1997. Legume seeds: protein content and nutritional value. Field Crops Res. 53:31-45.

Dwivedi, S. L., J. H. Crouch, S. N. Nigam, M. E. Ferguson, and A. H. Paterson. 2003. Molecular breeding of groundnut for enhanced productivity and food security in the semiarid tropics: Opportunities and challenges. Adv. Agron. 80:153-221.

El-Assal, S. E.-D., C. Alaonso-Blanco, A. J. M. Peeters, V. Raz, and M. Koornneef. 2001. A QTL for flowering time in Arabidopsis reveals a novel allele of CRY2. Nature Genet. 29:435-444.

Ellis, R. H., T. D. Hong, E. H. Roberts, and K.-L. Tao. 1990. Low moisture content limits to relations between seed longevity and moisture. Ann. Bot. 65:493-504.

Ellis, T. H. N., L. Turner, R. P. Hellens, D. Lee, C. L. Harker, C. Enard, C. Domoney, and D. R. Davies. 1992. Linkage map in pea. Genetics 130:649-663.

Endo, M., H. Matsubara, T. Kokubun, H. Masuko, Y. Takahata, T. Tsuchiya, H. Fukuda, T. Demura, and M. Watanabe. 2002. The advantage of cDNA microarrays as an effective tool for identification of reproductive organ-specific genes in a model legume, Lotus japonicus. FEBS Letters 514:229-237.

Endre, G., A. Kereszt, Z. Kevei, S. Mihacea, P. Kalo, and G. B. Kiss. 2002. A receptor kinase regulating symbiotic nodule development. Nature 417:962-966.

Ermolaeva, O., M. Rastogi, K. D. Pruitt, G. D. Schuler, M. L. Bittner, Y. Chen, R. Simon, P. Meltzer, J. M. Trent, and M. S. Boguski. 1998. Data management and analysis for gene expression arrays. Nat. Genet. 20:19-23.

Ermolayev, V., W. Weschke, and R. Manteuffel. 2003. Comparison of Al-induced gene expression in sensitive and tolerant soybean cultivars. J. Expt. Bot. 54:2754-2756.

Erskine, W., M. Tufail, A. Russell, M. C. Tyagi, M. M. Rahman, and M. C. Saxena. 1994. Current and future strategies in breeding lentil for resistance to biotic and abiotic stresses. Euphytica 73:127-135.

Erskine, W., and J. R. Witcombe. 1984. Lentil Germplasm Catalog. ICARDA, Aleppo, Syria.

Eujayl, I., M. Baum, W. Powell, W. Erskine, and E. Pehu. 1998a. A genetic linkage map of lentil (Lens sp.) based on RAPD and AFLP markers using recombinant inbred lines. Theor. Appl. Genet. 97:83-89. 
Eujayl, I., W. Erskine, B. Bayaa, M. Baum, and E. Pehu. 1998b. Fusarium vascular wilt in lentil: inheritance and identification of DNA markers for resistance. Plant Breed. 117:497-499.

Eujayl, I., W. Erskine, M. Baum, and E. Pehu. 1999. Inheritance and linkage analysis of frost injury in lentil. Crop Sci. 39:639-642.

Eujayl, I., M. K. Sledge, L. Wang, G. D. May, K. Chekhovskiy, J. C. Zwontizer, and M. A. R. Mian. 2004. Medicago truncatula EST-SSRs reveal cross-species genetic markers for Medicago spp. Theor. Appl. Genet. 108:414-422.

Evans, A. M. 1973. Plant architecture and physiological efficiency in the field bean. p. 279-284. In: D. Wall (ed.), Potentials of field bean and other food legumes in Latin America. CIAT, Cali, Colombia.

Evans, A. M. 1980. Structure, variation, evolution, and classification in Phaseolus. p. 337-347. In: R. J. Summerfield and A. H. Bunting (eds.), Advances in legume science. Royal Botanic Gardens, Kew, UK.

Ezedinma, F. O. C., and F. O. Maneke. 1985. Preliminary studies on bambara groundnut (Voandzeia subterranean Thouars) in the derived Savanna Belt of Nigeria. Trop. Grain Legume Bul. 31:39-44.

Faleiro, F. G., W. S. Vinhadelli, V. A. Ragagnin, R. X. Correa, M. A. Moreira, and E. G. deBarros. 2000. RAPD markers linked to a block of genes conferring rust resistance to the common bean. Genet. Mol. Biol. 23:399-402.

Fall, A. L., P. F. Byrne, G. Jung, D. P. Coyne, M. A. Brick, and H. F. Schwartz. 2001. Detection and mapping of a major locus for fusarium wilt resistance in common bean. Crop Sci. 41:1494-1498.

FAO. 1996. Global plan of action for the conservation and sustainable utilization of plant genetic resources and Leipzig declaration, adopted by the International Technical Conference on Plant Genetic Resources, Leipzig, Germany, 17-23 June 1996. Rome: Food and Agricultural Organization of the United Nations.

FAO. 1998. The state of the world's plant genetic resources for food and agriculture. FAO, Rome, Italy. pp. 465-484.

FAO. 2001. http://apps.fao.org/page/collections?subset=agriculture.

FAO. 2002. http://apps.fao.org/page/collections?subset=agriculture.

Fatokun, C. A., D. I. Menancio-Hautea, D. Danesh, and N. D. Young. 1993. Evidence of orthologous seed weight genes in cowpea and mung bean based on RFLP mapping. Genetics 132:841-846.

Fedorova, M., J. van de Mortel, P. A. Matsumoto, J. Cho, C. D. Town, K. A. VandenBosch, J. S. Gantt, and C. P. Vance. 2002. Genome-wide identification of nodule-specific transcripts in the model legume Medicago truncatula. Plant Physiol. 130:519-537.

Ferguson, M. E., M. Burow, S. R. Schulze, P. J. Bramel, A. Paterson, S. Kresovich, and S. Mitchell. 2004. Microsatellite identification and characterization in peanut $(A$. hypogaea L.). Theor. Appl. Genet. 108:1064-1070.

Ferreira, C. F., A. Borem, G. A. Carvalho, S. Nietsche, T. J. Paula, Jr., E. G. Barros, and M. A. Moreira. 2000. Cell biology and molecular genetics: inheritance of angular leaf spot resistance in common bean and identification of a RAPD marker linked to a resistance gene. Crop Sci. 40:1130-1133.

Ferrier-Cana, E., V. Geffroy, C. Macadre, F. Creusot, P. Imbert-Bollore, M. Sevignac, and T. Langin. 2003. Characterization of expressed NBS-LRR resistance gene candidates from common bean. Theor. Appl. Genet. 106:251-261.

Fiehn, O., J. Kopka, P. Dormann, T. Altmann, R. N. Trethewey, and L. Willmitzer. 2000. Metabolite profiling for plant functional genomics. Nature Biotech. 18:1157-1161. 
Fitch, W. M. 1970. Distinguishing homologous from analogous proteins. Syst. Zool. 19:99-113.

Fjellstrom, R. G., J. J. Steiner, and P. R. Beuselinck. 2003. Tetrasomic linkage mapping of RFLP, PCR, and isozyme loci in Lotus corniculatus. Crop Sci. 43:1006-1020.

Flandez-Galvez, H., R. Ford, E. C. K. Pang, and P. W. J. Taylor. 2003. An intraspecific linkage map of the chickpea (Cicer arietinum L.) genome based on sequence tagged microsatellite site and resistance gene analog markers. Theor. Appl. Genet. 106: 1447-1456.

Flavell, A. J., V. N. Bolshakov, A. Booth, R. Jing, J. Russell, T. H. Ellis, and P. Isaac. 2003. A microarray-based high throughput molecular marker genotyping method: the tagged microarray marker (TAM) approach. Nucl. Acid Res. 31:19-155.

Flavell, A. J., D. B. Smith, and A. Kumar. 1992. Extreme heterogeneity of Ty1-copia group retrotransposons in plants. Mol. Gen. Genet. 231:233-242.

Flint-Garcia, S. A., J. M. Thornsberry, and E. S. Buckler IV. 2003. Structure of linkage disequilibrium in plants. Ann. Rev. Plant Biol. 54:357-374.

Fodor, S. 1997. Massively parallel genomics. Science 277:393.

Fofana, B., X. Vekemans, P. du Jardin, and J. P. Baudoin. 1997. Genetic diversity in lima bean (Phaseolus lunatus L.) as revealed by RAPD markers. Euphytica 95:157-165.

Ford, R., K. L. Roux, C. Itman, J. B. Brouwer, and P. W. J. Taylor. 2002. Diversity analysis and genotyping with sequence tagged microsatellite sites (STMS) primers. Euphytica 124:397-405.

Forster, B. P., J. R. Russell, R. P. Ellis, L. L. Handley, D. Robinson, C. A. Hackett, E. Nevo, R. Waugh, D. C. Gordon, R. Keith, and W. Powell. 1997. Locating genotypes and genes for abiotic stress tolerance in barley: a strategy using maps, markers and the wild species. New Physiol. 137:141-147.

Foster-Hartnett, D., J. Mudge, D. Larsen, D. Danesh, H. Yan, R. Denny, S. Penuela, and N. D. Young. 2002. Comparative genomic analysis of sequences sampled from a small region on soybean (Glycine max) molecular linkage group G. Genome 45:634-645.

Fouilloux, G. 1979. New races of bean anthracnose and consequences on our breeding programs. p. 221-235. In: H. Maraite and J. A. Meyer (eds.), Intl. Symp. Dis. Trop. Food Crops, Universite Catholique de Louvain-la-Neuve, Louvain-la-Neuve, Belgium.

Francki, M. G., P. Whitaker, P. M. Smith, and C. A. Atkins. 2002. Differential expression of a novel gene during seed triacylglycerol accumulation in lupin species (Lupinus angustifolius and L. mutabilis L.). Funct. Integr. Genom. 2:292-300.

Frew, T. J., A. C. Russell, and G. M. Timmerman-Vaughan. 2002. Sequence tagged site markers linked to the $s b m 1$ gene for resistance to pea seedborn mosaic virus in pea. Plant Breed. 121:512-516.

Freyre, R., P. W. Skroch, V. Geffroy, A.-F. Adam-Blondon, A. Shirmohamadali, W. C. Johnson, V. Llaca, R. O. Nodari, P. A. Pereira, S.-M. Tsai, J. Tohme, M. Dron, J. Niehuis, C. E. Vallejos, and P. Gepts. 1998. Towards an integrated linkage map of common bean. 4. Development of a core linkage map and alignment of RFLP map. Theor. Appl. Genet. 97:847-856.

Freytag, G. F., and D. G. Debouck. 2002. Taxonomy, distribution, and ecology of the genus Phaseolus (Leguminosae-Papilionoideae) in North America, Mexico, and Central America. Sida, Botanical Miscellany 23. Botanical Research Institute of Texas, Forth Worth, TX.

Fulton, T. M., R. van der Haven, N. T. Eannetta, and S. D. Tanksley. 2002. Identification, analysis, and utilization of conserved ortholog set markers for comparative genomics in higher plants. Plant Cell 14:1457-1467. 
Gaitan-Solis, E., M. C. Duque, K. J. Edwards, and J. Tohme. 2002. Microsatellite repeats in common bean (Phaseolus vulgaris): isolation, characterization, and cross-species amplification in Phaseolus ssp. Crop Sci. 42:2128-2136.

Gale, M. D., and K. M. Davos. 1998. Comparative genetics in the grasses. Proc. Natl. Acad. Sci. (USA) 95:1971-1974.

Galibert, F., T. M. Finan, S. R. Long, A. Puhler, P. Abola, F. Ampe, F. Barloy-Hubler, M. J. Barnett, A. Backer, P. Boistard, G. Bothe, M. Boutry, L. Bowser, J. Buhrmester, E. Cadieu, D. Capela, P. Chain, A. Cowie, R. W. Davis, S. Dreano, N. A. Federspiel, R. F. Fisher, S. Gloux, T. Godrie, A. Goffeau, B. Golding, J. Gouzy, M. Gurjal, I. Hernandez-Lucas, A. Hong, L. Huizar, R. W. Hayman, T. Jones, D. Kahn, M. L. Kahn, S. Kalman, D. H. Keating, E. Kiss, C. Komp, V. Lelaure, D. Masuy, C. Palm, M. C. Peck, T. M. Pohl, D. Portetelle, B. Purnelle, U. Ramsperger, R. Surzycki, P. Thebault, M. Vandenbol, F.J. Vorholter, S. Weidner, D. H. Wells, K. Wong, K.-C. Yeh, and J. Batut. 2001. The composite genome of the legume symbiont Sinorhizobium meliloti. Science 293:668-672.

Gallardo, K., C. L. Signor, J. Vandekerckhove, R. D. Thompson, and J. Burstin. 2003. Proteomics of Medicago truncatula seed development establishes the time frame of diverse metabolic processes related to reserve accumulation. Plant Physiol. 133:664-682.

Gallardo, K. C. J., S. P. C. Groot, M. Puype, H. Demol, J. Vandekerckhove, and D. Job. 2001. Proteomic analysis of Arabidopsis seed germination and priming. Plant Physiol. 126: 835-848.

Gamas, P., F. D. Niebel, N. Lescure, and J. V. Cullimore. 1996. Use of a substractive hybridization approach to identify new Medicago truncatula genes induced during root nodule development. Mol. Plant Microbe Interact. 9:233-242.

Garry, G., B. Tivoli, M. H. Jeuffroy, and J. Citharel. 1996. Effects of Ascochyta blight caused by Mycosphaerella pinodes on the translocation of carbohydrates and nitrogenous compounds from the leaf and hull to the seed of dried pea. Plant Pathol. 45:769-777.

Garvin, D. F., and N. F. Weeden. 1994. Isozyme evidence supporting a single geographic origin for domesticated tepary bean. Crop Sci. 34:1390-1395.

Gaur, R. B., and R. D. Singh. 1996. Effects of Ascochyta blight on grain yield and protein in chickpea. Indian J. Myco. Plant Pathol. 26:259-262.

Gebhardt, C., A. Ballvora, B. Walkemeier, P. Oberhagemann, and K. Schuler. 2004. Assessing genetic potential in germplasm collections of crop plants by marker-trait association: a case study for potatoes with quantitative variation of resistance to late blight and maturity type. Mol. Breed. 13:93-102.

Geffroy, V., F. Creusot, J. Falquet, M. Sévignac, A. F. Adam-Blondon, H. Bannerot, P. Gepts, and M. Dron. 1998. A family of LRR sequences in the vicinity of the Co-2 locus for anthracnose resistance in Phaseolus vulgaris and its potential use in marker-assisted selection. Theor. Appl. Genet. 96:494-502.

Geffroy, V., D. Sicard, J. C. de Oliveira, M. Sevignac, S. Cohen, P. Gepts, C. Neema, T. Langin, and M. Dron. 1999. Identification of an ancestral resistance gene cluster involved in the coevolution process between Phaseolus vulgaris and its fungal pathogen Colletotrichum lindemuthianum. Mol. Plant Microbe Interact. 12:774-784.

Genta, H. D., M. L. Genta, N. V. Alvarez, and M. S. Santana. 2002. Production and acceptance of a soy candy. J. Food Eng. 53:199-202.

Gepts, P., and D. Debouck. 1991. Origin, domestication, and evolution of the common bean (Phaseolus vulgaris L.). p. 7-53. In: A. van Schoonhoven and O. Voysest (eds.), Common beans: Research for crop improvement. C.A.B. Intl., Wallingford, UK and CIAT, Cali, Colombia.

Gerhold, D., T. Rushmore, and C. T. Caskey. 1999. DNA chips: promising toys have become powerful tools. Trends Biochem. 4:168-173. 
Gibbings, J. G., B. P. Cook, M. R. Dufault, S. L. Madden, S. Khuri, C. J. Turnbull, and J. M. Dunwell. 2003. Global transcript analysis of rice leaf and seed using SAGE technology. Plant Biotechnol. J. 1:271-285.

Gilmour, S. J., D. G. Zarka, E. J. Stockinger, M. P. Salazar, J. M. Houghton, and M. F. Thomashow. 1998. Low temperature regulation of the Arabidopsis CBF family of AP2 transcriptional activators as an early step in cold-induced COR gene expression. Plant J. 16:433-442.

Gilpin, B. J., J. A. McCallum, T. J. Frew, and G. M. Timmerman-Vaughan. 1997. A linkage map of the pea (Pisum sativum L.) genome containing cloned sequences of known function and expressed sequence tags (ESTs). Theor. Appl. Genet. 95:1289-1299.

Girke, T., J. Todd, S. Ruuska, J. White, C. Benning, and J. Ohlrogge. 2000. Microarray analysis of developing Arabidopsis seeds. Plant Physiol. 124:1570-1581.

Gizlice, Z., T. E. Carter Jr., and J. W. Burton. 1993. Genetic diversity in North American soybean: I. Multivariate analysis of founding stock and relation to coefficient of parentage. Crop Sci. 33:614-620.

Gizlice, Z., T. E. Carter Jr., and J. W. Burton. 1994. Genetic base for North American public soybean cultivars released between 1947 and 1988. Crop Sci. 34:1143-1151.

Gizlice, Z., T. E. Carter Jr., T. M. Gerig, and J. W. Burton. 1996. Genetic diversity patterns in North American public soybean cultivars based on coefficient of parentage. Crop Sci. 36:753-765.

Glenn, E., J. J. Brown, and E. Blumwald. 1999. Salt-tolerant mechanisms and crop potential of halophytes. Critic. Rev. Plant Sci. 18:227-255.

Goff, S. A., and J. M. Salmeron. 2004. Back to the future of cereals. Scientific American 291:42-48.

Goldblatt, P. 1981. Cytology and the phylogeny of Leguminosae. p. 427-463. In: R. M. Polhill and P. H. Raven (eds.), Advances in legume systematics, Part 2. Kew: Royal Botanic Gardens.

Gomathinayagam, P., S. G. Ram, R. Rathnaswamy, and N. M. Ramaswamy. 1998. Interspecific hybridization between $V$. unguiculata (L.) Walp. and $V$. vexillata (L.) A. Rich. through in vitro embryo culture. Euphytica 102:203-209.

Goossens, A., C. Quintero, W. Dillen, R. D. Rycke, J. F. Valor, J. de Clercq, M. van Montagu, C. Cardona, and G. Angenon. 2000. Analysis of bruchid resistance in the wild common bean accession G02771: no evidence for insecticidal activity of arcelin 5. J. Expl. Bot. 51:1229-1236.

Gopalakrishna, R., G. Kumar, B. T. K. Prasad, M. K. Mathew, and M. U. Kumar. 2001. A stress-responsive gene from groundnut, Gdi-15, is homologous to flavonol 3-Oglucosyltransferase involved in anthocyanin biosynthesis. Biochem. Biophys. Res. Commun. 284:574-579.

Gore, M. A., A. J. Hayes, S. C. Jeong, Y. G. Yue, G. R. Buss, and M. A. Saghai Maroof. 2002. Mapping tightly linked genes controlling potyvirus infection at the Rsv1 and Rpv1 region on soybean. Genome 45:592-599.

Gowda, B. S., J. L. Miller, S. S. Rubin, D. R. Sharma, and M. P. Timko. 2002. Isolation, sequence analysis and linkage mapping of r-gene analogs in cowpea (Vigna unguiculata L Walp). Euphytica 126:365-377.

Graham, P. H., and C. P. Vance. 2003. Legumes: importance and constraints to greater use. Plant Physiol. 131:872-877.

Grant, D., P. Cregan, and R. C. Shoemaker. 2000. Genome organization in dicots: Genome duplication in Arabidopsis and synteny between soybean and Arabidopsis. Proc. Nat. Acad. Sci. (USA) 97:4168-4173. 
Gresshoff, P. M. 2003. Post-genomic insights into plant nodulation symbioses. Genome Biol. 4:201.1-201.5 (http://genomebiology.com/2003/4/1/201).

Grierson, D., G. W. Lycett, and G. A. Tucker. 1996. Mechanisms and applications of gene silencing. Nottingham: Univ. Press. 205 pp.

Grunwald, N. J., V. A. Coffman, and J. M. Kraft. 2003. Sources of partial resistance to Fusarium root rot in the Pisum core collection. Plant Dis. 87:1197-1200.

Grusak, M. A. 2002. Enhancing mineral content in plant food products. J. Am. Coll. Nutr. 21:178S-183S.

Gu, W. K., N. F. Weeden, J. Yu, and D. H. Wallace. 1995. Large scale cost effective screening of PCR products in marker-assisted selection applications. Theor. Appl. Genet. 91:465-470.

Gualtieri, G., O. Kulikova, E. Limpens, D.-J. Kim, D. R. Cook, T. Bisseling, and R. Geurts. 2002. Microsynteny between pea and Medicago truncatula in the SYM2 region. Plant Mol. Biol. 50:225-235.

Guo, H., H. Yang, T. C. Mockler, and C. Lin. 1998. Regulation of flowering time by Arabidopsis photoreceptors. Science 279:1360-1363.

Gutiérrez Salgado, A., P. Gepts, and D. G. Debouck. 1995. Evidence for two gene pools of the lima bean, Phaseolus lunatus L., in the Americas. Genet. Resour. Crop Evol. 42:15-28.

Guzman-Maldonado, S. H., O. Martinez, J. A. Acosta-Gallegos, F. Guevara-Lara, and O. Paredes-Lopez. 2003. Putative quantitative trait loci for physical and chemical components of common bean. Crop Sci. 43:1029-1035.

Gyorgyey, J., D. Vaubert, J. I. Jimenez-Zurdo, C. Charon, L. Troussard, A. Kondorosi, and E. Kondorosi. 2000. Analysis of Medicago truncatula nodule expressed tags. Mol. Plant Microbe Interact. 13:62-71.

Hagenblad, J., and M. Nordborg. 2002. Sequence variation and haplotype structure surrounding the flowering time locus FRI in Arabidopsis thaliana. Genetics 161:289-298.

Haley, S. D., L. Afanador, and J. D. Kelly. 1994. Identification and application of a random amplified polymorphic DNA marker for the $I$ gene (potyvirus resistance) in common bean. Phytopathology 84:157-160.

Haley, S. D., P. N. Miklas, J. R. Stavely, J. Byrum, and J. D. Kelly. 1993. Identification of RAPD markers linked to a major rust resistance gene block in common bean. Theor. Appl. Genet. 86:505-512.

Halford, N. G. 2004. Prospects for genetically modified crops. Ann. Appl. Biol. 145:17-24.

Hall, A. E., N. Cisse, S. Thiaw, H. O. A. Elawad, J. D. Ehlers, A. M. Ismail, R. L. Fery, P. A. Roberts, L. W. Kitch, L. L. Murdock, O. Boukar, R. D. Phillips, and K. H. McWatters. 2003. Development of cowpea cultivars and germplasm by the Bean/Cowpea CRSP. Field Crops Res. 82:103-134.

Hall, A. E., B. B. Singh, and J. D. Ehlers. 1997. Cowpea breeding. Plant Breed. Rev. 15:215-274.

Hall, J. M., C. A. LeDuc, A. R. Watson, and A. H. Roter. 1996. An approach to high throughput genotyping. Genome Res. 6:781-790.

Hamdi, A., I. Kusmenoglu, and W. Erskine. 1996. Sources of winter hardiness in wild lentil. Genet. Resour. Crop Evol. 43:63-67.

Hammer, G. L., M. J. Kropff, T. R. Sinclair, and J. R. Porter. 2002. Future contribution of crop modeling: from heuristics and supporting decision making to understanding genetic regulation and adding crop improvement. Eur. J. Agron. 18:15-31.

Hammond-Kosack, K., and J. Jones. 1997. Plant disease resistance genes. Annu. Rev. Plant Physio. 48:575-608.

Handberg, K., and J. Stougaard. 1992. Lotus japonicus, an autogamous, diploid legume species for classical and molecular genetics. Plant J. 2:487-496. 
Hannan, R. M., W. J. Kaiser, and F. J. Muehlbauer. 1994. Development and utilization of the USDA chickpea germplasm core collection. p. 217. In: Agron. Abstr., ASA, Madison, WI.

Hansen, M., T. Kraft, S. Ganestam, T. Sall, and N. O. Nilsson. 2001. Linkage disequilibrium mapping of the bolting gene in sea beet using AFLP markers. Genet. Res. 77:61-66.

Hanson, W. D. 1959. Early generation analysis of lengths of heterozygous chromosome segments around a locus held heterozygous with backcrossing or selfing. Genetics 44:833-837.

Hardie, D. C., and S. L. Clement. 2001. Development of bioassays to evaluate wild pea germplasm for resistance to pea weevil (Coleoptera: Bruchidae). Crop Prot. 20:517-522.

Harlan, J. R., and J. M. J. de Wet. 1971. Toward a rational classification of cultivated plants. Taxon 20:509-517.

Hart, S. E., S. Glenn, and W. W. Kenworthy. 1991. Tolerance and the basis for selectivity to 2,4-D in perennial Glycine species. Weed Sci. 39:535-539.

Hartman, G. L., M. E. Gardner, T. Hymowitz, and G. C. Naidoo. 2000. Evaluation of perennial Glycine species for resistance to soybean fungal pathogens that cause Sclerotinia stem rot and sudden death syndrome. Crop Sci. 40:545-549.

Harvey, M. J. 2004. Application of genomic technologies to crop plants: Opportunities and challenges. Crop Sci. 44:1893-1895.

Haussmann, B. I. G., H. K. Parzies, T. Presterl, Z. Susic, and T. Miedaner. 2004. Plant genetic resources in crop improvement. Plant Genetic. Resourc. 2:3-21.

Hawkins, C. F., and A. M. Evans. 1973. Elucidating the behaviour of pollen tubes in intraand interspecific pollinations of Phaseolus vulgaris and P. coccineus. Euphytica 22:378-385.

Hayashi, H., L. Mustardy, P. Deshnium, M. Ida, and N. Murata. 1997. Transformation of Arabidopsis thaliana with the coda gene for choline oxidase: accumulation of glycinebetaine and enhanced tolerance to salt and cold stress. Plant J. 12:133-142.

Hayashi, M., A. Miyahara, S. Sato, T. Kato, M. Yoshikawa, M. Taketa, M. Hayashi, A. Pedrosa, R. Onda, H. Imaizumi-Anraku, A. Bachmair, N. Sandal, J. Stougaard, Y. Murooka, S. Tabata, S. Kawasaki, M. Kawaguchi, and K. Harada. 2001. Construction of a genetic linkage map of the model legume Lotus japonicus using an intraspecific $\mathrm{F}_{2}$ population. DNA Res. 8:301-310.

Hayman, D. S. 1974. Plant growth responses to vesicular-arbuscular endomycorrhiza VI. Effects of light and temperature. New Phytol. 73:71-80.

Hayman, D. S. 1983. The physiology of vesicular-arbuscular endomycorrhizal symbiosis. Can. J. Bot. 61:944-963.

Hepper, F. N. 1963. The Bambara groundnut (Voandzeia subterranean) and Kersting's groundnut (Kerstingiella geocarpa) wild in the West Africa. Kew Bul. 16:395-407.

Hernandez, G., M. Ramírez, M. W. Blair, M. Lara, L. Blanco, M. Muño, S. Barazesh, E. Verdoorn, M. Graham, and C. P. Vance. 2004. Comparative analysis of common bean (Phaseolus vulgaris) nodule, root, pod and leaf expressed sequence tag (ESTs) libraries: a platform for "Phaseomics" research. AEP/ICLGG meeting presented paper, Dijon, France.

Hidalgo, R., and S. Beebe. 1997. Phaseolus beans. p. 139-155. In: D. Fuccillo, L. Sears, and P. Stapleton (eds.), Biodiversity in trust. Cambridge Univ. Press, UK.

Hill, W. G., and B. S. Weir. 1994. Maximum-likelihood estimation of gene location by linkage disequilibrium. Am. J. Hum. Genet. 54:705-714.

Hittalmani, S., A. Parco, T. V. Mew, and R. S. Zeigler. 2000. Fine mapping and DNA marker-assisted pyramiding of three major genes for blast resistance in rice. Theor. Appl. Genet. 100:1121-1128. 
Hnetkovsky, N., S. J. C. Chang, T. W. Doubler, P. T. Gibson, and D. A. Lightfoot. 1996. Genetic mapping of loci underlying field resistance to soybean sudden death syndrome (SDS). Crop Sci. 36:393-400.

Hoeck, J. A., W. R. Fehr, R. C. Shoemaker, G. A. Welke, S. L. Johnson, and S. R. Cianzio. 2003. Molecular marker analysis of seed size in soybean. Crop Sci. 43:68-74.

Hoffman, D. D., G. L. Hartman, D. S. Mueller, R. A. Leits, C. D. Nickell, and W. L. Pedersen. 1998. Yield and seed quality of soybean cultivars infected with Sclerotinia sclerotiorum. Plant Dis. 82:826-829.

Holbrook, C. C., W. F. Anderson, and R. N. Pittman. 1993. Selection of a core collection from the US germplasm collection of peanut. Crop Sci. 33:859-861.

Holbrook, C. C., and H. T. Stalker. 2003. Peanut breeding and genetic resources. Plant Breed. Rev. 22:297-356.

Holbrook, C. C., M. G. Stephenson, and A. W. Johnson. 2000. Level and geographical distribution of resistance to Meloidogyne arenaria in the U.S. peanut germplasm collection. Crop Sci. 40:1168-1171.

Holly, L. 2001. Status of grain legume collections in Hungary. p. 84-87. In: L. Magioni, M. Ambrose, R. Schachl, G. Duc, and E. Lipman (compilers), Report of a Working Group on Grain Legumes. Third Meeting, 5-7 July 2001, Krakow, Poland. IPGRI, Rome, Italy.

Holmberg, N., and L. Bulow. 1998. Improving stress tolerance in plants by gene transfer. Trends Plant Sci. 3:61-66.

Holtorf, H., M.-C. Guitton, and R. Reski. 2002. Plant functional genomics. Naturwissenschaften 89:235-249.

Hopkins, M. S., A. M. Casa, T. Wang, S. E. Mitchell, R. E. Dean, G. D. Kochert, and S. Kresovich. 1999. Discovery and characterization of polymorphic simple sequence repeats (SSRs) in peanut. Crop Sci. 39:1243-1247.

Huang, N., E. R. Angeles, J. Domingo, G. Magpantay, S. Singh, G. Zhang, N. Kumaravadivel, J. Bennett, and G. S. Khush. 1997. Pyramiding of bacterial blight resistance genes in rice: marker-assisted selection using RFLP and PCR. Theor. Appl. Genet. 95:313-320.

Huaracha, E., M. Xu, and S. S. Korban. 2004. Narrowing down the region of the $V f$ locus for scab resistance in apple using AFLP-derived SCARS. Theor. Appl. Genet. 108:274-279.

Huettel, B., F. J. Santra, F. J. Muehlbauer, and G. Kahl. 2002. Resistance gene analogues of chickpea (Cicer arietinum L.): isolation, genetic mapping and association with a Fusarium resistance gene cluster. Theor. Appl. Genet. 105:479-490.

Huettel, B., P. Winter, K. Weising, W. Choumane, F. Weigand, and G. Kahl. 1999. Sequencetagged microsatellite site markers for chickpea (Cicer aeritinum L.). Genome 42:210217.

Humphry, M. E., V. Konduri, C. J. Lambrides, T. Magner, C. L. McIntyre, E. A. B. Aitken, and C. J. Liu. 2002. Development of a mungbean (Vigna radiata) RFLP linkage map and its comparison with lablab (Lablab purpureus) reveals a high level of colinearity between the two genomes. Theor. Appl. Genet. 105:160-166.

Hymowitz, T., R. J. Singh, and K. P. Kollipara. 1998. The genomes of the Glycine. Plant Breed. Rev. 16:289-317.

Ideker, T., V. Thorsson, J. A. Ranish, R. Christmas, J. Buhler, J. K. Eng, R. Bumgarner, D. R. Goodlett, R. Aebersold, and L. Hood. 2001. Integrated genomic and proteomic analyses of a systematically perturbed metabolic network. Science 292:929-934.

IBPGR. 1976. Report of IBPGR working group on engineering, design and cost aspects of long-term seed storage facilities. International Board for Plant Genetic Resources, Rome.

IBPGR. 1980. Descriptors for mung bean (Vigna radiata L.). International Board of Plant Genetic Resources, Rome. 
IBPGR. 1982. Descriptors for common bean (Phaseolus vulgaris L.). International Board of Plant Genetic Resources, Rome.

IBPGR. 1983a. Descriptors for cowpea (Vigna unguiculata L.). International Board of Plant Genetic Resources, Rome.

IBPGR. 1983b. Descriptors for faba bean (Vicia faba L.). International Board of Plant Genetic Resources, Rome.

IBPGR. 1984. Descriptors for soybean (Glycine max). International Board of Plant Genetic Resources, Rome.

IBPGR. 1985a. Descriptors for lentil (Lens culnaris L). International Board of Plant Genetic Resources, Rome.

IBPGR. 1985b. Descriptors for tepary bean (Phaseolus acutifolius Gray). International Board of Plant Genetic Resources, Rome

IBPGR and ICRISAT. 1992. Descriptors for groundnut (Arachis hypogaea L.). International Board of Plant Genetic Resources, Rome, Italy; International Crops Research Institute for the Semi-Arid Tropics, Patancheru, India.

IBPGR and ICRISAT. 1993. Descriptors for pigeonpea (Cajanus cajan (L.) Millsp.). International Board of Plant Genetic Resources, Rome, Italy; International Crops Research Institute for the Semi-Arid Tropics, Patancheru, India.

IBPGR, ICRISAT, and ICARDA. 1993. Descriptors for chickpea (Cicer arietinum L.). International Board of Plant Genetic Resources, Rome, Italy; International Crops Research Institute for the Semi-Arid Tropics, Patancheru, India; and International Center for Agricultural Research in the Dry Areas, Aleppo, Syria.

Ibrahim, A. M., and D. P. Coyne. 1975. Genetics of stigma shape, cotyledon position, and flower color in reciprocal crosses between Phaseolus vulgaris L. and Phaseolus coccineus (Lam.) and implications in breeding. J. Am. Soc. Hort. Sci. 100:622-626.

ICARDA. 1996. Annual Report 1995. Germplasm program Legumes. ICARDA, Alleppo, Syria. pp. 210.

ICRISAT. 2002a. Harnessing biotechnology for the poor. Archival Report 2002. p. 89-92. In: International Crops Research Institute for the Semi-Arid Tropics (ICRISAT), ICRISAT, Patancheru 502324, AP, India. [http://www.icrisat.org/gt1/Archival\% 20 Report\% 202002.pdf]

ICRISAT. 2002b. Crop management and utilization for food security and health. Archival Report. p. 35. In: International Crops Research Institute for the Semi-Arid Tropics (ICRISAT), ICRISAT, Patancheru 502324, AP, India.

ICRISAT. 2004. Harnessing biotechnology for the poor. Archival Report 2003. p. 31-36. In: International Crops Research Institute for the Semi-Arid Tropics (ICRISAT), ICRISAT, Patancheru 502324, AP, India.

Igartua, E., A. M. Casas, F. Ciudad, J. L. Montoya, and I. Romagosa. 1999. RFLP markers associated with major genes controlling heading date evaluated in a barley germplasm pool. Heredity 83:551-559.

Ignacimuthu, S., and C. R. Babu. 1987. Vigna radiata var. sublobata (Fabaceae): Economically useful wild relative of urd and mung beans. Econ. Bot. 41:418-422.

IITA. 2001. International Institute of Tropical Agriculture (IITA), Ibadan, Nigeria, Annual Report 2001. pp. 50.

IITA. 2002. IITA 2002 Workplanning Week Abstracts. International Institute of Tropical Agriculture, Ibadan, Nigeria. $60 \mathrm{pp}$.

IITA. 2003. IITA 2003 Workplanning Week Abstracts. International Institute of Tropical Agriculture, Ibadan, Nigeria. $59 \mathrm{pp}$.

Infantino, A., A. Porta-Puglia, and K. B. Singh. 1996. Screening of wild Cicer species for resistance to Fusarium wilt. Plant Dis. 80:42-44. 
INIA, IPGRI, and MADRP. 2001a. Descriptors for common bean (Phaseolus vulgaris L.). International Plant Genetic Resources Institute, Rome.

INIA, IPGRI, and MADRP. 2001b. Descriptors for lima bean (Phaseolus lunatus L.). International Plant Genetic Resources Institute, Rome.

International HapMap Consortium. 2004. Integrating ethics and science in the international HapMap project. Nature Rev. 5:467-474.

IPGRI. 2000. Descriptors for Lathyrus spp. Int. Plant Genetic Resources Inst., Rome.

IPGRI. 2003. Descriptors for scarlet runner bean (Phaseolus coccineus L.). Int. Plant Genetic Resources Inst., Rome.

IPGRI, IITA, and BAMNET. 2000. Descriptors for bambara groundnut (Vigna subterranean). Int. Plant Genetic Resources Inst., Rome; Int. Inst. Tropical Agriculture, Ibadan, Nigeria; The Int. Bambara Groundnut Network, Germany.

Irzykowska, L., B. Wolko, and W. K. Swiecicki. 2001. The genetic linkage map of pea (Pisum sativum L.) based on molecular marker, biochemical, and morphological markers. Pisum Genet. 33:13-18.

Ishikawa, S., J. J. Adu-Gyamfi, T. Nakamura, T. Yoshihara, and T. Wagatsuma. 2002. Genotypic variability in phosphorous solubilizing activity of root exudates by pigeonpea grown in low nutrient environments. Plant Soil 245:71-81.

Ishizaki-Nishizawa, O., T. Fujii, M. Azume, K. Sekiguchu, N. Murata, T. Ohtani, and T. Toguri. 1996. Low temperature resistance of higher plants is significantly enhanced by a nonspecific cyanobacterial desaturase. Nat. Biotech. 14:1003-1006.

Islam, F. M. A., K. E. Basford, R. J. Redden, C. Jara, and S. Beebe. 2002. Patterns of resistance to angular leaf spot, anthracnose, and common bacterial blight in common bean germplasm. Australian J. Expt. Agr. 42:481-490.

Ismail, A. M., A. E. Hall, and T. J. Close. 1999. Allelic variation of a dehydrin gene cosegregates with chilling tolerance during seedling emergence. Proc. Natl. Acad. Sci. (USA). 96:13566-13570.

Ivandic, V., C. A. Hackett, E. Nevo, R. Keith, W. T. B. Thomas, and B. P. Forster. 2002. Analysis of simple sequence repeats (SSRs) in wild barley from the Fertile Crescent: associations with ecology, geography, and flowering time. Plant Mol. Biol. 48:511-527.

Ivandic, V., W. T. B. Thomas, E. Nevo, Z. Zhang, and B. P. Forster. 2003. Associations of simple sequence repeats with quantitative trait variation including biotic and abiotic stress tolerance in Hordeum spontaneum. Plant Breed. 122:300-304.

Jaccoud, D., K. Peng, D. Feinstein, and A. Kilian. 2001. Diversity arrays: a solid state technology for sequence information independent genotyping. Nucl. Acids Res. 29 No. $4 \mathrm{e} 25$.

Jacinto-Hernandez, C., S. Azpiroz-Rivero, J. A. Acosta-Gallegos, H. Hernandez-Sanchez, and I. Bernal-Lugo. 2003. Genetic analysis and random amplified polymorphic DNA markers associated with cooking time in common bean. Crop Sci. 43:329-332.

Jackson, M. T., and A. G. Yunus. 1984. Variation in grasspea (Lathyrus sativus L.) and wild species. Euphytica 33:549-559.

James, C. 2003. Global status of commercialized transgenic crops: 2003 (Executive summary). International Service for the Acquisition of Agri-Biotech Applications. No. 30 (http://www.isaaa.org/kc/CBTNews/press_release/briefs30/es_b30.pdf).

Jander, G., S. Norris, S. Rounsley, D. Bush, I. Levin, and R. Last. 2002. Arabidopsis mapbased cloning in the post-genome era. Plant Physiol. 129:440-450.

Jiang, Q., and P. M. Gresshoff. 1997. Classical and molecular genetics of the model legume Lotus japonicus. Mol. Plant-Microbe Interact. 10:59-68. 
Johanson, U., J. West, C. Lister, S. Michaels, R. Amasino, and C. Dean. 2000. Molecular analysis of FRIGIDA, a major determinant of natural variation in Arabidopsis flowering time. Science 290:344-347.

Johnson, E., P. N. Miklas, J. R. Stavely, and J. C. Martinez-Cruzado. 1995. Coupling- and repulsion-phase RAPDs for marker-assisted selection of PI 181996 rust resistance in common bean. Theor. Appl. Genet. 90:659-664.

Johnson, W. C., P. Guzmán, D. Mandala, A. B. C. Mkandawire, S. Temple, R. L. Gilbertson, and P. Gepts. 1997. Molecular tagging of the $b c-3$ gene for introgression into Andean common bean. Crop Sci. 37:248-254.

Jong, W. S., D. M. de Jong, and M. Bodis. 2003. A fluorogenic 5' nuclease (TaqMan) assay to assess dosage of a marker tightly linked to red skin color in autotetraploid potato. Theor. Appl. Genet. 107:1384-1390.

Jordan, D. R., Y. Tao, I. D. Godwin, R. G. Henzell, M. Cooper, and C. L. McIntyre. 2003. Prediction of hybrid performance in grain sorghum using RFLP markers. Theor. Appl. Genet. 106:559-567.

Journet, E. P., D. Tuinen, J. Gouzy, H. Crespeau, V. Carreau, M. J. Farmer, A. Niebel, T. Schiex, O. Jaillon, O. Chatagnier, L. Godiard, F. Micheli, D. Kahn, V. GianinazziPearson, and P. Gamas. 2002. Exploring root symbiotic programs in the model legume Medicago truncatula using EST analysis. Nucl. Acid Res. 30:5579-5592.

Jung, G., H. M. Ariyarathne, D. P. Coyne, and J. Nienhuis. 2003. Mapping QTL for bacterial brown spot resistance under natural infection in field and seeding stem inoculation in growth chamber in common bean. Crop Sci. 43:350-357.

Jung, G., D. P. Coyne, P. W. Skroch, J. Nienhuis, E. Arnaud-Santana, J. Bokosi, H. M. Ariyarathne, J. R. Steadman, J. S. Beaver, and S. M. Kaeppler. 1996. Molecular markers associated with plant architecture and resistance to common blight, web blight, and rust in common beans. J. Am. Soc. Hort. Sci. 121:794-803.

Jung, G., P. W. Skroch, D. P. Coyne, J. Nienhuis, E. Arnaud-Santana, H. M. Ariyarathne, S. M. Kaeppler, and M. J. Bassett. 1997. Molecular-marker-based genetic analysis of tepary bean-derived common bacterial blight resistance in different developmental stages of common bean. J. Am. Soc. Hort. Sci. 122:329-337.

Jung, G., P. W. Skroch, J. Nienhuis, D. P. Coyne, E. Arnaud-Santana, H. M. Ariyarathe, and J. M. Marita. 1999. Confirmation of QTL associated with common bacterial blight resistance in four different genetic backgrounds in common bean. Crop Sci. 39:1448-1455.

Jung, S., G. Powell, K. Moore, and A. Abbott. 2000b. The high oleate trait in the cultivated peanut (Arachis hypogaea L). II. Molecular basis and genetics of the trait. Mol. Gen. Genet. 263:806-811.

Jung, W., O. Yu, S.-M. C. Lau, D. P. O’Keefe, J. Odell, G. Fader, and B. McGonigle. 2000a. Identification and expression of isoflavone synthase, the key enzyme for biosynthesis of isoflavones in legumes. Nature Biotech. 18:208-212.

Kaga, A., and M. Ishimoto. 1998. Genetic localization of a bruchid resistance gene and its relationship to insecticidal cyclopeptide alkaloids, the vignatic acids, in mungbean (Vigna radiata L. Wilczek). Mol. Gen. Genet. 258:378-384.

Kaga, A., T. Ishii, K. Tsukimoto, E. Tokoro, and O. Kamijima. 2000. Comparative molecular mapping in Ceratotropis species using an interspecific cross between adzuki bean (Vigna angularis) and rice bean (V. umbellata). Theor. Appl. Genet. 100:207-213.

Kaga, A., M. Ohnishi, T. Ishii, and O. Kamijima. 1996. A genetic linkage map of adzuki bean constructed with molecular and morphological markers using an interspecific population (Vigna angularis $\times$ Vigna nakashimae). Theor. Appl. Genet. 93:658-666.

Kajita, T., H. Ohashi, Y. Tateishi, C. D. Bailey, and J. J. Doyle. 2001. rbcL and legume phylogeny, with reference to Phaseoleae, Millettieae, and allies. Syst. Bot. 26:515-536. 
Kanazin, V., L. F. Marek, and R. C. Shoemaker. 1996. Resistance gene analogs are conserved and clustered in soybean. Proc. Natl. Acad. Sci. (USA) 93:11746-11750.

Kaneko, T., E. Asamizu, T. Kato, S. Sato, Y. Nakamura, and S. Tabata. 2003. Structural analysis of a Lotus japonicus genome. III. Sequence features and mapping of sixty-two TAC clones which cover the 6.7 Mb regions of the genome. DNA Res. 10:27-33.

Kar, S., D. Basu, S. Das, N. A. Ramkrishna, P. Mukherjee, P. Nayak, and S. K. Sen. 1997. Expression of cryIA(c) gene of Bacillus thuringiensis in transgenic chickpea plants inhibits development of pod borer (Heliothis armigera) larvae. Transgenic Res. 6:177-185.

Karikari, S. K. 1972. Correlation studies between yield and some agronomic characters in Bambara groundnut (Voandzeia subterranean Thouars). Ghana J. Agr. Sci. 5:79-83.

Kasha, K. J., and K. N. Kao. 1970. High frequency haploid production in barley (Hordeum vulgare L.). Nature 225:874-876.

Kassem, M. A., K. Meksem, M. J. Iqbal, V. N. Njiti, W. J. Banz, T. A. Winters, A. Wood, and D. A. Lightfoot. 2004. Definition of soybean genomic regions that control seed phytoestrogen amounts. J. Biomed. Biotech. 4:52-60.

Kasuga, M., Q. Liu, S. Miura, K. Yamaguchi-Shinozaki, and K. Shinozaki. 1999. Improving plant drought, salt, and freezing tolerance by gene transfer of a single stressinducible transcription factor. Nat. Biotech. 17:287-291.

Kato, T., S. Sato, Y. Nakamura, T. Kaneko, E. Asamizu, and S. Tabata. 2003. Structural analysis of a Lotus japonicus genome. V. Sequence features and mapping of sixty-four TAC clones which cover the 6.4 Mb regions of the genome. DNA Res. 10:277-285.

Kaul, A. K., M. Q. Islam, and A. Hamid. 1986. Screening of Lathyrus germplasm of Bangladesh for BOAA content and some agronomic characters. p. 130-141. In: A. K. Kaul and D. Coombes (eds.), Lathyrus and Lathyrism, Proc. Intl. Symp. Sponsored by the Institut De Biochenotique Experimentale Des Agrosystemes (IBEAS) and Universite De Pau Et Des Pays De I'Adour, 9-13 September 1985.

Keim, P., J. M. Schupp, S. E. Travis, K. Clayton, T. Zhu, L. Shi, A. Ferreira, and D. M. Webb. 1997. A high-density soybean genetic map based on AFLP markers. Crop Sci. 37:537-543.

Kelly, J. D., P. Gepts, P. N. Miklas, and D. P. Coyne. 2003. Tagging and mapping of genes and QTL and molecular marker-assisted selection for traits of economic importance in bean and cowpea. Field Crops Res. 82:135-154.

Kennedy, A. R. 1995. The evidence for soybean products as cancer preventing agents. J. Nutr. 125:S733-S743.

Kindscher, K. 1992. Medicinal wild plants of the Prairie. Univ. Press of Kansas, Lawrence.

Kinney, A. J. 1995. Improving soybean seed quality. Proc. Intern. Symp. on induced mutations and molecular techniques for crop improvement. Vienna, 19-23 June. pp. 101-113.

Kitano, H. 2002. System biology: a brief overview. Science 253:146-152.

Knights, E. J., R. S. Southwell, and M. W. Schwinghaumer. 2003. Evaluation of wild Cicer species for resistance to phytophthora root rot. p. 54-58. In: R. N. Sharma, G. K. Srivastava, A. L. Rathore, M. L. Sharma, and M. A. Khan (eds.), Chickpea research for the millenium. Proc. Int. Chickpea Conf., 20-22 January 2003, Indira Gandhi Agri. Univ., Raipur, Chhattisgarh, India.

Knox, M. R., and T. H. N. Ellis. 2002. Excess heterozygosity contributes to genetic map expansion in pea recombinant inbred populations. Genetics 162:861-873.

Koinange, E. M. K., S. P. Singh, and P. Gepts. 1996. Genetic control of the domestication syndrome in common bean. Crop Sci. 36:1037-1045. 
Konieczny, A., and F. M. Ausubel. 1993. A procedure for mapping Arabidopsis mutations using co-dominant ecotype-specific PCR-based markers. Plant J. 4:403-410.

Koning, G., D. M. TeKrony, T. W. Pfeiffer, and S. A. Ghabrial. 2001. Infection of soybean with mosaic virus increases susceptibility to Phomopsis spp. seed infection. Crop Sci. 41:1850-1856.

Kornegay, J., C. Cardona, and C. E. Posso. 1993. Inheritance of resistance to Mexican bean weevil in common bean, determined by bioassay and biochemical tests. Crop Sci. 33:589-594.

Kouchi, H., K. Shimomura, S. Hata, A. Hirota, G.-J. Wu, H. Kumagai, S. Tajima, N. Suganuma, A. Suzuki, T. Aoki, M. Hayashi, T. Yokoyama, T. Ohyama, E. Asamizu, C. Kuwata, D. Shibata, and S. Tabata. 2004. Large-scale analysis of gene expression profiles during early stages of root nodule formation in a model legume, Lotus japonicus. DNA Res. 11:263-274.

Kraakman, A. T. W., R. E. Niks, P. M. M. M. Van den Berg, P. Stam, and F. A. Van Eeuwjik. 2004. Linkage disequilibrium mapping of yield and yield stability in modern spring barley cultivars. Genetics 168:435-446.

Krapovickas, A., and W. C. Gregory. 1994. Taxonomia del genero Arachis (Leguminosae). Bonplandia VIII:1-187.

Krishnamurthy, L., J. Kashiwagi, H. D. Upadhyaya, and R. Serraj. 2003. Genetic diversity of drought-avoidance root traits in the mini-core germplasm collection of chickpea. Intl. Chickpea and Pigeonpea Newsl. 10:21-24.

Kulikova, O., G. Gualtieri, R. Geurts, D. J. Kim, D. Cook, T. Huguet, J. H. de Jong, P. F. Fransz, and T. Bisseling. 2001. Integration of the FISH pachytene and genetic maps of Medicago truncatula. Plant J. 27:49-58.

Kulkarni, N. K., A. S. Reddy, P. L. Kumar, J. Vijaynarsimha, K. T. Rangaswamy, V. Muniyappa, L. J. Reddy, K. B. Saxena, A. T. Jones, and D. V. R. Reddy. 2003. Broadbased resistance to pigeonpea sterility mosaic disease in accessions of Cajanus scarabaeoides (L.) Benth. Indian J. Plant Protection 31:6-11.

Kumar, J., and S. Abbo. 2001. Genetics of flowering time in chickpea and its bearing on productivity in semi-arid environments. Adv. Agron. 72:107-138.

Kumar, J. V. D. K., P. J. Dart, and P. V. S. S. Sastry. 1983. Residual effect of pigeonpea (Cajanus cajan) on yield and nitrogen response of maize. Expt. Agr. 19:131-141.

Kumar, S. V., S. G. Tan, S. C. Quah, and K. Yusoff. 2002. Isolation of microsatellite markers in mungbean, Vigna radiata. Mol. Ecol. Notes 2:96-98.

Kupicha, F. K. 1983. Infrageneric structure of Lathyrus. Notes RBG Edinb 41:209-244.

Kuster, H., N. Hohnjec, F. Krajinski, F. El-Yahyaoui, K. Manthey, J. Gouzy, M. Dondrup, F. Mayer, J. Kalinowski, L. Brechenmacher, D. van Tuinen, V. Gianinazzi-Pearson, A. Puhler, P. Gamas, A. Becker, and D. van Tuinen. 2004. Construction and validation of cDNA-based Mt6k-RIT macro- and microarrays to explore root endosymbioses in the model legume Medicago truncatula. J. Biotechnol. 108:95-113.

Kwok, P. Y., and Z. Gu. 1999. SNP libraries: why and how are we building them? Mol. Medicine Today 12:538-543.

Ladizinsky, G. 1993. Wild lentils. Critic. Rev. Plant Sci. 12:169-184.

Ladizinsky, G., and A. Adler. 1976. Genetic relationships among the annual species of Cicer L. Theor. Appl. Genet. 48:197-204.

Ladizinsky, G., B. Pickersgill, and K. Yamamato. 1988. Exploitation of wild relatives of the food legumes. p. 967-978. In: R. J. Summerfield (ed.), World crops: cool season food legumes. Kluwer Acad. Publ., Dordrecht, The Netherlands.

Lamblin, A. F. J., J. A. Crow, J. E. Johnson, K. A. T. Silverstein, T. M. Kunau, A. Kilian, D. Benz, M. Stromvik, G. Endre, K. A. VandenVosch, D. R. Cook, N. D. Young, and E. F. 
Retzel. 2003. MtDB: a database for personalized data mining of the model legume Medicago truncatula transcriptome. Nucl. Acid Res. 31:196-201.

Lander, E. S., and D. Botstein. 1989. Mapping Mendelian factors underlying quantitative traits using RFLP genetic linkage maps. Genetics 121:185-199.

La Rota, M., and M. E. Sorrells. 2004. Comparative DNA sequence analysis of mapped wheat ESTs reveals the complexity of genome relationships between rice and wheat. Funct. Integrat. Genom. 4:34-46 (Online: DOI:10.1007/s10142-003-0098-2).

Lash, A. E., C. M. Tolstoshev, L. Wagner, G. D. Schuler, R. L. Strausberg, G. J. Riggins, and S. F. Altschul. 2000. SAGEmap: A public gene expression resource. Genome Res. 10:1051-1060.

Laucou, V., K. Haurogne, N. Ellis, and C. Rameau. 1998. Genetic mapping in pea. 1. RAPDbased genetic linkage map of Pisum sativum. Theor. Appl. Genet. 97:905-915.

Lawn, R., W. Williams, and B. C. Imrie. 1988. Potential of wild germplasm as a source of tolerance to environmental stresses in mungbean. p. 136-145. In: Mungbean Proc. 2nd Int. Symp., AVRDC, Taiwan.

Lee, G. J., H. R. Boerma, M. R. Villagarcia, X. Zhou, T. E. Carter Jr., Z. Li, and M. O. Gibbs. 2004. A major QTL conditioning salt tolerance in S-100 soybean and descendent cultivars. Theor. Appl. Genet. 109:1610-1619.

Lee, S. H., K. Y. Park, H. S. Lee, E. H. Park, and H. R. Boerma. 2001. Genetic mapping of QTL conditioning soybean sprout yield and quality. Theor. Appl. Genet. 103:702-709.

Leister, R. T., and F. Katagiri. 2000. A resistance gene product of the nucleotide binding site-leucine rich repeats class can form a complex with bacterial avirulence proteins in vivo. Plant J. 22:345-354.

Lemieux, B., A. Aharoni, and M. Schena. 1998. Overview of DNA chip technology. Mol. Breed. 4:277-289.

Leon, A. J., M. Lee, and F. H. Andrade. 2001. Quantitative trait loci for growing degree days to flowering and photoperiod response in sunflower (Helianthus annuus L.). Theor. Appl. Genet. 102:497-503.

Leprei, O., L. Bassie, G. Safwat, P. Thu-Hang, P. Trung-Nghia, E. Holtta, P. Christou, and T. Copell. 2001. Over-expression of cDNA for human ornithine decarboxylase in transgenic rice plants alters the polyamine pool in a tissue specific manner. Mol. Gen. Genet. 266:303-312.

Lewis, G. P., B. D. Schrire, B. A. Mackinder, and J. M. Lock (editors). 2003. Legumes of the world. Royal Botanic Gardens, Kew, UK.

Li, C.-D., C. A. Fatokun, B. Ubi, B. B. Singh, and G. J. Scoles. 2001. Determining genetic similarities and relationships among cowpea breeding lines and cultivars by microsatellite markers. Crop Sci. 41:189-197.

Liao, L., P. Chen, G. R. Buss, Q. Yang, and S. A. Tolin. 2002. Inheritance and allelism of resistance to soybean mosaic virus in Zao18 soybean from China. J. Hered. 93:447-452.

Lim, S. M., and T. Hymowitz. 1987. Reaction of perennial wild species of Genus Glycine to Septoria glycines. Plant Dis. 71:891-893.

Lin, H. 1996. Utilization of wild soybean (Glycine soja and G. gracilis) for the creation of new superior germplasm. Oil Crops China 18:70-72.

Lin, S., S. Cianzio, and R. Shoemaker. 1997. Mapping genetic loci for iron deficiency chlorosis in soybean. Mol. Breed. 3:219-229.

Lin, T.-Y., L.-R. Chen, R.-X. Tzeng, and Z.-G. Giang. 2004. Profiling temperature stressresponded gene expression in Vigna radiata by microarray analysis. Intl. Plant and Animal Genome Conference. Poster \#1033. (http://www.Life.nthu.edu.tw/ islty).

Lioi, L., and R. Bollini. 1989. Identification of a new arcelin variant in wild bean seeds. Bean Improv. Cooperative 32:28. 
Lipshutz, R. J., S. P. A. Fodor, T. R. Gingeras, and D. J. Lockhart. 1999. High density synthetic oligonucleotide arrays. Nat. Genet. 21:20-24.

Liu, Q., M. Kasuga, Y. Sakuma, H. Abe, S. Miura, K. Yamaguchi-Shinozaki, and K. Shinozaki. 1998. Two transcription factors, DREB1 and DREB2, with an EREBP/AP2 DNA binding domain separate two cellular signal transduction pathways in drought- and low-temperature-responsive gene expression, respectively, in Arabidopsis. Plant Cell 10:1391-1406.

Liu, Y.-G., N. Mitsukawa, C. Lister, C. Dean, and R. F. Whittier. 1996. Isolation and mapping of a new set of 129 RFLP markers in Arabidopsis thaliana using recombinant inbred lines. Plant J. 10:733-736.

Liu, Z., A. Nichols, P. Li, and R. Dunham. 1998. Inheritance and usefulness of AFLP markers in channel fish (Ictalurus punctatus), blue catfish (I. furcatus) and their $\mathrm{F}_{1}, \mathrm{~F}_{2}$ and backcross hybrids. Mol. Gen. Genet. 258:260-268.

Lockhart, D. J., H. Dong, M. C. Byrne, M. T. Follettie, M. V. Gallo, M. S. Chee, M. Mittmann, C. Wang, M. Kobayashi, H. Horton, and E. L. Brown. 1996. Expression monitoring by hybridization to high-density oligonucleotide arrays. Nature Biotechnol. 14:1675-1680.

Lopez, Y., H. L. Nadef, O. D. Smith, J. P. Comnnell, A. S. Reddy, and A. K. Fritz. 2000. Isolation and characterization of the $\Delta^{12}$-fatty acid desaturase in peanut (Arachis hypogaea L.) and search for polymorphisms for the high oleate trait in Spanish market-type lines. Theor. Appl. Genet. 100:1131-1138.

Lukoki, L., R. Marechal, and E. Otoul. 1980. Les ancetres sauvages des haricots cultives: Vigna radiata (L.) Wilczek et V. mungo (L.) Hepper. Bull. Jard. Bot. Nat. Belgique 50: 385-391.

Lumpkin, T. A., and D. C. McClary. 1994. Adzuki bean: botany, production, and uses. CAB Int., Wallingford, UK.

Mace, E. S., H. K. Buhariwalla, and J. H. Crouch. 2003. A high-throughput DNA extraction protocol for tropical molecular breeding programs. Plant Mol. Biol. Reptr. 21:459-460.

Maguire, T. L., S. Grimmond, A. Forrest, I. Iturbe-Ormaetxe, K. Meksem, and P. Gresshoff. 2002. Tissue-specific gene expression in soybean (Glycine max) detected by cDNA microarray analysis. J. Plant Physiol. 159:1361-1374.

Mahalakshmi, V., P. Aparana, S. Ramadevi, and R. Ortiz. 2002. Genomic sequence derived simple sequence repeat markers-Case study with Medicago spp. Electronic J. Biotechnol. 5:233-242. http://www.ejbiotechnology.info/content/vol5/issue3/full/2/index.html

Mahuku, G. S., C. Jara, C. Cajiao, and S. Beebe. 2003. Sources of resistance to angular leaf spot (Phaeoisariopsis griseola) in common bean core collection, wild Phaseolus vulgaris and secondary gene pool. Euphytica 130:303-313.

Maleck, K., A. Levin, T. Eulgem, A. Morgan, J. Schmid, K. A. Lawton, J. L. Dangl, and R. A. Dietrich. 2000. The transcriptome of Arabidopsis thaliana during systemic acquired resistance. Nat. Genet. 26:403-410.

Malhotra, R. S., G. Khalaf, S. Hajjar, and S. Arslan. 2003. Interspecific hybridization in chickpea. p. 41-50. In: R. N. Sharma, G. K. Srivastava, A. L. Rathore, M. L. Sharma, and M. A. Khan (eds.), Chickpea research for the millennium. Proc. of the Intl. Conf. 20-22 Jan. 2003. Indira Gandhi Agr. Univ., Raipur, Chhattisgarh, India.

Malhotra, R. S., K. B. Singh, M. Vinto, N. Greco, and M. C. Saxena. 2002. Registration of ILC 10765 and ILC 10766 chickpea germplasm lines resistant to cyst nematode. Crop Sci. 42:1756.

Mallikarjuna, N., and J. P. Moss. 1995. Production of hybrids between Cajanus platycarpus and Cajanus cajan. Euphytica 83:43-46.

Mallikarjuna, N., and K. B. Saxena. 2002. Production of hybrids between Cajanus acutifolius and Cajanus cajan. Euphytica 124:107-110. 
Manshardt, R. M., and M. J. Bassett. 1984. Inheritance of stigma position in Phaseolus vulgaris $\times$ P. coccineus hybrid populations. J. Hered. 75:45-50.

Mansur, L. M., J. H. Orf, K. Chase, T. Jarvik, P. B. Cregan, and K. G. Lark. 1996. Genetic mapping of agronomic traits using recombinant inbred lines of soybean. Crop Sci. 36:1327-1336.

Maquet, A., I. Z. Bi, M. Delvaux, B. Wathelet, and J. P. Baudoin. 1997. Genetic structure of a lima bean base collection using allozyme markers. Theor. Appl. Genet. 95:980-991.

Marechal, R., J. M. Mascherpa, and F. Stainer. 1978. Taxonomic study of one complex group of species from Phaseolus-Vigna genera based on morphology and pollinology data treated to computer analysis (in French). Boissiera 28:1-273.

Marra, M., T. Kucaba, M. Sekhon, L. Hillier, R. Martienssen, A. Chinwalla, J. M. Crockett, J. Fedele, H. Grover, C. Gund, W. R. McCombie, K. McDonald, J. McPherson, N. Mudd, L. Parnell, J. Schein, R. Seim, P. Shelby, R. Waterston, and R. Wilson. 1999. A map for sequence analysis of the Arabidopsis thaliana genome. Nat. Genet. 22:265-270.

Matamoros, M. A., M. R. Clemente, S. Sato, E. Asamizu, S. Tabata, J. Ramos, J. F. Moran, J. Stiller, P. M. Gresshoff, and M. Becana. 2003. Molecular analysis of the pathway for the synthesis of thiol tripeptides in the model legume Lotus japonicus. Mol. PlantMicrobe Interact. 16:1039-1046.

Mathesius, U., G. Keijzers, S. H. Natera, J. J. Weinman, M. A. Djordjevic, and B. G. Rolf. 2001. Establishment of a root proteome reference map for the model legume Medicago truncatula using the expressed sequence tag database for peptide mass fingerprinting. Proteomics 1:1424-1440.

Mathur, P. B., M. J. Devi, R. Serraj, K. Yamaguchi-Shinozaki, V. Vadez, and K. K. Sharma. 2004. Evaluation of transgenic groundnut lines under water limited conditions. Intl. Arachis Newslett. 24:33-34.

Matsumura, H., S. Reich, A. Ito, H. Saitoh, S. Kamoun, P. Winter, G. Kahl, M. Reuter, D. H. Kruger, and R. Terauchi. 2003. Gene expression analysis of plant host-pathogen interactions by SuperSAGE. Proc. Nat. Acad. Sci., USA 100:15718-15723.

Maughan, P. J., M. A. Saghai-Maroof, and G. R. Buss. 1996. Molecular-marker analysis of seed weight: genomic locations, gene action, and evidence for orthologous evolution among three legume species. Theor. Appl. Genet. 93:574-579.

Maxted, N. 1993. A phenetic investigation of Vicia L. (Leguminosae-Vicieae). Bot. J. Linn. Soc. 111:155-182.

Mazur, B., E. Krebbers, and S. Tingey. 1999. Gene discovery and product development for grain quality traits. Science 285:372-375.

McCallum, J., G. Timmerman-Vaughan, T. Frew, and A. Russell. 1997. Biochemical and genetic linkage analysis of green seed color in field pea. J. Amer. Soc. Hort. Sci. 122: 218-225.

McClean, P., P. Gepts, and J. Kami. 2004. Genomics and genetic diversity in common bean. p. 60-82. In: R. F. Wilson, H. T. Stalker, and E. C. Brummer (eds.), Legume crop genomics. AOCS Press, Champaign, Illinois.

McClendon, M. T., D. A. Inglis, K. E. McPhee, and C. J. Coyne. 2002. DNA markers linked to Fusarium wilt race 1 resistance in pea. J. Amer. Soc. Hort. Sci. 127:602-607.

McCutchan, J. S. 2003. Review: A brief history of grasspea and its use in crop improvement. Lathyrus Lathyrism Newsl. 3:18-23.

Mckersie, B. D., S. R. Bowley, E. Harjanto, and O. Leprince. 1996. Water deficit tolerance and field performance of transgenic alfalfa overexpressing superoxide dismutase. Plant Physiol. 111:1177-1181.

McPhee, K. E., A. Tullu, J. M. Kraft, and F. J. Muehlbauer. 1999. Resistance to Fusarium wilt race 2 in the Pisum core collection. J. Amer. Soc. Hort. Sci. 124:28-31. 
Mehta, R. A, T. Cassol, N. Li, N. Ali, A. K. Handa, and A. K. Mattoo. 2002. Engineered polyamine accumulation in tomato enhances phytonutrient content, juice quality and vine life. Nat. Biotechnol. 20:613-618.

Mejía-Jiménez, A., C. Muñoz, H. J. Jacobsen, W. M. Roca, and S. P. Singh. 1994. Interspecific hybridization between common and tepary beans: increased hybrid embryo growth, fertility, and efficiency of hybridization through recurrent and congruity backcrossing. Theor. Appl. Genet. 88:324-331.

Meksem, K., V. N. Njiti, W. J. Banz, M. J. Iqbal, M. M. Kassem, D. L. Hyten, J. Yuang, T. A. Winters, and D. A. Lightfoot. 2001a. Genomic regions that underlie soybean seed isoflavone content. J. Biomed. Biotech. 1:38-44.

Meksem, K., E. Ruben, D. Hyten, K. Triwitayakorn, and D. A. Lightfoot. 2001b. Conversion of AFLP bands into high-throughput DNA markers. Mol. Genet. Genom. 265:207-214.

Meksem, K., E. Ruben, D. L. Hayten, M. E. Schmidt, and D. A. Lightfoot. 2001c. Highthroughput genotyping for a polymorphism linked to soybean cyst nematode resistance gene $R h g^{4}$ by using Taqman ${ }^{\mathrm{TM}}$ probes. Mol. Breed. 7:63-71.

Meksem, K., E. Ruben, K. Zobrist, D. Hyten, Q. Tao, H. B. Zhang, and A. D. Lightfoot. 2000. Two plant transformations ready for bacterial artificial chromosome libraries for soybean: applications in chromosome walking and genome-wide physical mapping. Theor. Appl. Genet. 101:747-755.

Melo, L. C., J. B. dos Santos, and D. F. Ferreira. 2002. Mapping QTL for reaction to powdery mildew and to angular leaf spot in common beans under different environments. Pesquisa-Agropecuaria-Brasileira 37:1115-1126.

Melotto, M., L. Afanador, and J. D. Kelly. 1996. Development of a SCAR marker linked to the I gene in common bean. Genome 39:1216-1219.

Melotto, M., and J. D. Kelly. 2001. Fine mapping of the Co-4 locus of common bean reveals a resistance gene candidate, $C O K-4$, that encodes for a protein kinase. Theor. Appl. Genet. 103:508-517.

Men, A. E., K. Meksem, M. A. Kassem, D. Lohar, J. Stiller, D. Lightfoot, and P. M. Gresshoff. 2001. A bacterial artificial chromosome library of Lotus japonicus constructed in an Agrobacterium tumefaciens-transformable vector. Mol. Plant Microbe Interact. 14:422-425.

Menancio-Hautea, D., C. A. Fatokun, L. Kumar, D. Danesh, and N. D. Young. 1993. Comparative genome analysis of mungbean (Vigna radiata L. Wilczek) and cowpea ( $V$. unguiculata L. Walpers) using RFLP mapping data. Theor. Appl. Genet. 86:797-810.

Mendoza, A., F. Hernandez, S. Hernandez, D. Ruiz, M. de la Vega, G. Mora, J. Acosta, and J. Simpson. 2001. Identification of Co-1 anthracnose resistance and linked molecular markers in common bean line A193. Plant Dis. 85:252-255.

Menendez, C. M., A. E. Hall, and P. Gepts. 1997. A genetic linkage map of cowpea (Vigna unguiculata) developed from a cross between two inbred, domesticated lines. Theor. Appl. Genet. 95:1210-1217.

Meriles, J. M., L. M. Giorda, and D. M. Maestri. 2002. Effect of planting dates on Fusarium sps. and Diaporthe/Phomopsis complex incidence and its relationship with soybean seed quality. J. Phytopathol. 150:606-610.

Mian, M. A. R., D. A. Ashley, and H. R. Boerma. 1998. An additional QTL for water use efficiency in soybean. Crop Sci. 38:390-393.

Mian, M. A. R., M. A. Bailey, J. P. Tamulonis, E. R. Shipe, T. E. Carter Jr., W. A. Parrott, D. A. Ashley, R. S. Hussey, and H. R. Boerma. 1996a. Molecular markers associated with seed weight in two soybean populations. Theor. Appl. Genet. 93:1011-1016. 
Mian, M. A. R., B. A. Bailey, D. A. Ashley, R. Wells, T. E. Carter Jr., W. A. Parrott, and H. R. Boerma. 1996b. Molecular markers associated with water use efficiency and leaf ash in soybean. Crop Sci. 36:1252-1257.

Miflin, B. 2000. Crop improvement in 21st century. J. Exp. Bot. 51:1-8.

Miklas, P. N., R. Delorme, R. Hannan, and M. H. Dickson. 1999. Using a subsample of the core collection to identify new sources of resistance to white mold in common bean. Crop Sci. 39:569-573.

Miklas, P. N., R. Delorme, and R. Riley. 2003. Identification of QTL conditioning resistance to white mold in snap bean. J. Am. Soc. Hort. Sci. 128:564-570.

Miklas, P. N., E. Johnson, V. Stone, J. S. Beaver, C. Montoya, and M. Zapata. 1996. Selective mapping of QTL conditioning disease resistance in common bean. Crop Sci. 36:1344-1351.

Miklas, P. N., R. C. Larsen, R. Riley, and J. D. Kelly. 2000. Potential marker-assisted selection for $b c-12$ resistance to bean common mosaic potyvirus in common bean. Euphytica 116:211-219.

Miklas, P. N., J. R. Stavely, and J. D. Kelly. 1993. Identification and potential use of a molecular marker for rust resistance in common bean. Theor. Appl. Genet. 85:745-749.

Millan, T., J. Rubio, M. Iruela, K. Daly, J. I. Cubero, and J. Gil. 2003. Markers associated with Ascochyta blight resistance in chickpea and their potential in marker-assisted selection. Field Crops Res. 84:373-384.

Molvig, L., L. M. Tabe, B. O. Eggum, A. E. Moore, S. Craig, D. Spencer, and T. J. V. Higgins. 1997. Enhanced methionine levels and increased nutritive value of seeds of transgenic lupins (Lupinus angustifolius L.) expressing a sunflower seed albumin gene. Proc. Nat. Acad. Sci. (USA) 94:8393-8398.

Mozo, T., K. Dewar, P. Dunn, J. R. Ecker, S. Fischer, S. Kloska, H. Lehrach, M. Marra, R. Martienssen, S. Meier-Ewert, and T. Altmann. 1999. A complete BAC-based physical map of the Arabidopsis thaliana genome. Nat. Genet. 22:271-275.

Mudge, J., P. B. Cregan, J. P. Kenworthy, W. J. Kenworthy, J. H. Orf, and N. D. Young. 1997. Two microsatellite markers that flank the major soybean cyst nematode resistance locus. Crop Sci. 37:1611-1615.

Mudge, J., Y. Huihuang, R. L. Denny, D. K. Howe, D. Danesh, L. F. Marek, E. Retzel, R. C. Shoemaker, and N. D. Young. 2004. Soybean artificial chromosome contigs anchored with RFLPs: insights into genome duplication and gene clustering. Genome 47:361-372.

Muehlbauer, F. J., W. J. Kaiser, and C. J. Simon. 1994. Potential for breeding wild species in cool season food legume breeding. p. 531-539. In: F. J. Muehlbauer and W. J. Kaiser (eds.), Expanding the production and use of cool season food legumes. Kluwer Academic Publishers, Dordrecht, The Netherlands.

Muehlbauer, G. J., J. E. Specht, M. A. Thomas-Compton, P. E. Staswick, and R. L. Bernard. 1988. Near-isogenic lines-A potential resource in the integration of conventional and molecular linkage maps. Crop Sci. 28:729-735.

Muñoz, L. C., M. W. Blair, M. C. Duque, W. Roca, and J. Tohme. 2004a. Level of introgression in inter-specific (Phaseolus vulgaris $\times$ P. acutifolius) congruity-backcross lines. Crop Sci. 44:637-645.

Muñoz, L. C., M. W. Blair, M. C. Duque, J. Tohme, and W. Roca. 2004b. Introgression in common bean $\times$ tepary bean interspecific congruity-backcross lines as measured by AFLP markers. Crop Sci. 44:637-645.

Muntz, K., V. Christov, G. Saalbach, T. Saalbach, D. Waddell, T. Pickardt, O. Schieder, and T. Wustenhagen. 1998. Genetic engineering for high methionine grain legumes. Nahrung 42:125-127. 
Murray, M. G., R. E. Cuellar, and W. F. Thompson. 1978. DNA sequence organization in the pea genome. Biochemistry 17:5781-5790.

Murray, M. G., D. L. Peters, and W. F. Thompson. 1981. Ancient repeated sequences in the pea and mungbean genomes and implications for genome evolution. J. Mol. Evol. 17:31-42.

Murti, V. V. S., T. R. Seshadiri, and T. A. Venkitasubramanian. 1964. Neurotoxic compounds of the seeds of Lathyrus sativus. Phytochemistry 3:877-891.

Myers, J. R. 2000. Tomorrow's snap bean cultivars. p. 39-51. In: S. P. Singh (ed.), Bean research, production and utilization. Proc. Idaho bean workshop, Univ. Idaho, Moscow, ID.

Myers, G. O., C. A. Fatokun, and N. D. Young. 1996. RFLP mapping of an aphid resistance gene in cowpea (Vigna unguiculata L. Walp). Euphytica 91:181-187.

Myers, J. R., and J. R. Baggett. 1999. Improvement of snap bean. p. 289-329. In: S. P. Singh (ed.), Common bean improvement in the twenty-first century. Kluwer, Dordrecht, The Netherlands.

Myers, J. R., J. R. Baggett, and C. Lamborn. 2001. Origin, history, and genetic improvement of the Snap pea (Pisum sativum L.). Plant Breed. Rev. 21:93-138.

Nakamura, Y., T. Kaneko, E. Asamizu, T. Kato, S. Sato, and S. Tabat. 2002. Structural analysis of a Lotus japonicus genome. II. Sequence features and mapping of sixty-five TAC clones which cover the 6.5 Mb regions of the genome. DNA Res. 9:63-70.

Nam, H.-G., J. Giraudat, B. den Boer, F. Moonan, W. D. B. Loos, and B. M. Hauge. 1989. Restriction fragment length polymorphism linkage map of Arabidopsis thaliana. Plant Cell 1:699-705.

Nam, Y. W., R. V. Penmasta, G. Endre, P. Uribe, D. J. Kim, and D. R. Cook. 1999. Construction of a bacterial artificial chromosome library of Medicago truncatula and identification of clones containing ethylene-response genes. Theor. Appl. Genet. 98:638-646.

Naoumkina, M. A., and R. A. Dixon. 2004. Microarray-based exploration of yeat-elicitor induced genes in Medicago truncatula. Plant and Animal Genomes XXII Conference, 10-14 January 2004, San Diego, CA, USA. (Poster 815).

Nasu, S., J. Sujuki, R. Ohta, K. Hasegawa, R. Yui, N. Kitazawa, L. Monna, and Y. Minobe. 2002. Search for and analysis of single nucleotide polymorphisms (SNPs) in rice (Oryza sativa, Oryza rufipogan) and establishment of SNP markers. DNA Res. 9:163-171.

Negi, M. S., M. Devic, M. Delseny, and M. Lakshmikumaran. 2000. Identification of AFLP fragments linked to seed coat colour in Brassica juncea and conversion to a SCAR marker for rapid selection. Theor. Appl. Genet. 101:146-152.

Neumann, P., M. Nouzova, and J. Macas. 2001. Molecular and cytogeneic analysis of repetitive DNA in pea (Pisum sativum L.). Genome 44:716-728.

Ng, N. Q., and B. B. Singh. 1997. Cowpea. p. 82-99. In: D. Fuccillo, L. Sears, and P. Stapleton (eds.), Biodiversity in trust. Cambridge Univ. Press, UK.

Niblack, T. L. 1992. The race concept. p. 73-86. In: R. D. Riggs and J. A Wrather (eds.), Biology and management of the soybean cyst nematode. APS Press, St. Paul, MN.

Nienhuis, J., T. Helentjaris, M. Slocum, B. Ruggero, and A. Schaefer. 1987. Restriction fragment length polymorphism analysis of loci associated with insect resistance in tomato. Crop Sci. 27:797-803.

Nodari, R. O., S. M. Tsai, P. Guzman, R. L. Gilbertson, and P. Gepts. 1993. Towards an integrated linkage map of common bean. III. Mapping genetic factors controlling hostbacteria interactions. Genetics 134:341-350.

Noel, G. R. 1992. History, distribution, and economics. p. 8-10. In: R. D. Riggs and J. A. Wrather (eds.), Biology and management of the soybean cyst nematode. APS Press, St. Paul, MN. 
Nordborg, M., J. O. Borevitz, J. Bergelson, C. C. Berry, J. Chory, J. Hagenblad, M. Kreitman, J. N. Maoof, T. Noyes, P. J. Oefner, E. A. Stahl, and D. Weigel. 2002. The extent of linkage disequilibrium in Arabidopsis thaliana. Nature Genet. 30:190-193.

Nordborg, M., and S. Tavare. 2002. Linkage disequilibrium: what history has to tell us. Trends Genet. 18:83-90.

Normile, D. 1999. Crossing rice strains to keep Asia's rice bowls brimming. Science 283:313.

Ogundiwin, E. A., G. Thottappilly, M. E. Aken'-Ova, E. J. A. Ekpo, and C. A. Fatokun. 2002. Resistance to cowpea mottle carmovirus in Vigna vexillata. Plant Breed. 121:517-520.

Ohashi, H., Y. Tateishi, T. Nemoto, and Y. Endo. 1988. Taxonomic studies on the Leguminosae of Taiwan III. Sci. Rep. Tohoku Univ. 4th ser. (Biology) 39:191-248.

Orf, J. H., K. Chase, T. Jarvik, L. M. Mansur, P. B. Cregan, F. R. Adler, and K. G. Lark. 1999a. Genetics of soybean agronomic traits: I. Comparison of three related recombinant inbred populations. Crop Sci. 39:1642-1651.

Orf, J. H., K. Chase, T. Jarvik, L. M. Mansur, P. B. Cregan, F. R. Adler, and K. G. Lark. 1999b. Genetics of soybean agronomic traits: II. Interactions between yield quantitative trait loci in soybean. Crop Sci. 39:1652-1657.

Ortiz, R. 2003. An international public partnership for genetic enhancement of cowpea using a holistic approach to biotechnology. Genomic/Proteomic Technol. 3:45-47.

Ortiz, R. 2004a. Legumes in the agriculture of developing nations. p. 5-8. In: Proc. 5th European Conference on Grain Legumes-2nd International Conference on Legume Genomics and Genetics, 7-11 June, Dijon, France. European Association for Grain Legume Research (AEP), Paris, France.

Ortiz, R. 2004b. Using genetic diversity in plant breeding: problems and prospects. Plant Genetic Res. Newslett. In press.

Osborn, T. C., D. C. Alexander, S. S. M. Sun, C. Cardona, and F. A. Bliss. 1988. Insecticidal activity and lectin homology of arcelin seed protein. Science 240:207-210.

Osborn, T. C., T. Blake, S. S. M. Sun, P. Gepts, and F. A. Bliss. 1986. Bean arcelin. 2. Genetic variation, inheritance and linkage relationships of a novel seed protein of Phaseolus vulgaris. Theor. Appl. Genet. 71:847-855.

Ouedraogo, J. T., B. S. Gowda, M. Jean, T. J. Close, J. D. Ehlers, A. E. Hall, A. G. Gillaspie, P. A. Roberts, A. M. Ismail, G. Bruening, P. Gepts, M. P. Timko, and F. J. Belzile. 2002a. An improved genetic linkage map for cowpea (Vigna unguiculata L.) combining AFLP, RFLP, RAPD, biochemical markers, and biological resistance traits. Genome 45:175-188.

Ouedraogo, J. T., J. B. Tignegre, M. P. Timko, and F. J. Belzile. 2002b. AFLP markers linked to resistance against Striga gesnerioides race 1 in cowpea (Vigna unguiculata). Genome 45:787-793.

Ouedraogo, J. T., V. Maheshwari, D. K. Berner, C.-A. St-Pierre, F. Belzile, and M. P. Timko. 2001. Identification of AFLP markers linked to resistance of cowpea (Vigna unguiculata L.) to parasitism by Striga gesnerioides. Theor. Appl. Genet. 102:1029-1036.

Pakniyat, H., W. Powell, E. Baired, L. L. Handley, D. Robinson, C. M. Scrimgeour, E. Novo, C. A. Hackett, P. D. S. Caligari, and B. P. Foster. 1997. AFLP variation in wild barley (Hordeum spontaneum C. Koch) with reference to salt tolerance and associated ecogeography. Genome 40:332-341.

Palmer, R. G., T. Hymowitz, and R. L. Nelson. 1995. Germplasm diversity within soybean. p. 1-35. In: D. P. S. Verma and R. C. Shoemaker (eds.). Soybean: Genetics, molecular biology and biotechnology. CABI, Wallingford, Oxon, UK.

Pandian, A., R. Ford, and P. W. J. Taylor. 2000. Transferability of sequence tagged microsatellite sites (STMS) primers across four major pulses. Plant Mol. Biol. Report. 18:395a-395h. 
Pantalone, V. R., W. J. Kenworthy, L. H. Slaughter, and B. R. James. 1997a. Chloride tolerance in soybean and perennial Glycine accessions. Euphytica 97:235-239.

Pantalone, V. R., G. J. Rebetzke, R. F. Wilson, and J. W. Burton. 1997b. Relationship between seed mass and linolenic acid in progenies of crosses between cultivated and wild soybean. J. Am. Oil Chem. Soc. 74:563-568.

Paran, I., I. Goldman, S. D. Tanksley, and D. Zamir. 1995. Recombinant inbred lines for genetic mapping in tomato. Theor. Appl. Genet. 90:542-548.

Paran, I., and R. W. Mitchelmore. 1993. Development of reliable PCR-based markers linked to downy mildew resistance gene in lettuce. Theor. Appl. Genet. 85:985-993.

Paris, M., R. H. Potter, R. C. M. Lance, C. D. Li, and M. G. K. Jones. 2003. Typing Mlo alleles for powdery mildew resistance in barley by single nucleotide polymorphism analysis using MALDI-ToF mass spectrometry. Australian J. Agr. Res. 54:1343-1349.

Park, S. O., D. P. Coyne, J. M. Bokosi, and J. R. Steadman. 1999. Molecular markers linked to genes for specific rust resistance and indeterminate growth habit in common bean. Euphytica 105:133-141.

Park, S. O., D. P. Coyne, J. R. Steadman, and P. W. Skroch. 2001. Mapping of QTL for resistance to white mold disease in common bean. Crop Sci. 41:1253-1262.

Park, S. O., D. P. Coyne, J. R. Steadman, and P. W. Skroch. 2003. Mapping of the Ur-7 gene for specific resistance to rust in common bean. Crop Sci. 43:1470-1476.

Pasquet, R. S. 1993a. Classification infraspecifique des formes spontanees de Vigna unguiculata (L.) Walp. A partir de donnees morphologiques. Bull. Jard. Bot. Nat. Belg. 62:127-173.

Pasquet, R. S. 1993b. Two new species of Vigna unguiculata (L.) Walp. (Leguminoseae: Papilionoideae). Kew Bul. 48:805-806.

Pasquet, R. S. 1994. Organisation evolutive des formes spontanees et cultivees du niebe, Vigna unguiculata (L.) Walp. Biosystematique et processus de domestication. These, INAPG, Paris, France.

Pasquet, R. S. 1997. A new species of Vigna unnguiculata (L.) (Leguminoseae: Papilionoideae). Kew Bul. 52:840.

Pasquet, R. S. 1999. Genetic relationships among subspecies of Vigna unguiculata (L) Walp. based on allozyne variation. Theor. Appl. Genet. 98:1104-1119.

Pasquet, R. S., and M. Fotso. 1997. The ORSTOM Bambara groundnut collection. p. 119-123. In: J. Heller, F. Begemann, and J. Mushonga (eds.), Bambara groundnut Vigna subterranea (L.) Verdc. Proc. Workshop on Conservation and Improvement of Bambara Groundnut, 14-16 November 1995, Harare, Zimbabwe. (Promoting the conservation and use of underutilized and neglected crops. 9.).

Pasquet, R. S., S. Schwedes, and P. Gepts. 1999. Isozyme diversity in bambara groundnut. Crop Sci. 39:1228-1236.

Pastor-Corrales, M. A., O. A. Erazo, E. I. Estrada, and S. P. Singh. 1994. Inheritance of anthracnose resistance in common bean accession G 2333. Plant Dis. 78:959-962.

Patarapuwadol, S., D. Jaccoud, J. Carling, V. Caig, S. Yang, M. Evers, M. Akbari, P. Wenzel, E. Huttner, and A. Kilian. 2004. Diversity arrays technology [TM]: high throughput and low-cost whole genome profiling. Plant and Animal Genomes XII Conference, January 10-14, 2004, San Diego, CA.

Paterson, A. H., J. E. Bowers, M. D. Burow, X. Draye, C. G. Elsik, C.-X. Jiang, C. S. Katsar, T.-H. Lan, Y.-R. Lin, R. Ming, and R. J. Wright. 2000. The comparative genomics of plant chromosomes. Plant Cell 12:1523-1539.

Paterson, A. H., E. S. Lander, J. D. Hewitt, S. Peterson, S. E. Lincoln, and S. D. Tanksley. 1988. Resolution of quantitative traits into Mendelian factors, using a complete linkage map of restriction fragment length polymorphism. Nature 335:721-726. 
Paterson, A. H., H. T. Stalker, M. Gallo-Meagher, M. D. Burow, S. L. Dwivedi, J. H. Crouch, and E. Mace. 2004. Genomics and genetic enhancement of peanut. p. 97-109. In: R. F. Wilson, H. T. Stalker, and E. C. Brummer (eds.), Legume crop genomics. AOCS Press, Champaign, Illinois.

Peakall, R., S. Gilmore, W. Keys, M. Morgante, and A. Rafalski. 1998. Cross-species amplification of soybean (Glycine max) simple sequence repeats (SSRs) within the genus and other legume genera: Implications for the transferability of SSRs in plants. Mol. Biol. Evol. 15:1275-1287.

Pearce, S. R., G. Harrison, D. Li, J. S. Heslop-Harrison, A. Kumar, and A. J. Flavell. 1996. The Ty1-copia group retrotransposans in Vicia species: copy number, sequence heterogeneity, and chromosomal location. Mol. Gen. Genet. 250:305-313.

Pedrosa, A., N. Sandels, J. Stougaard, D. Schweizer, and A. Bachmair. 2002. Chromosomal map of model legume Lotus Japonicus. Genetics 161:1661-1672.

Peleman, J. D., and J. R. van der Voort. 2003. Breeding by design. Trend Plant Sci. 8:330-334.

Pellegrineschi, A., M. Reynolds, M. Pacheco, R. M. Brito, R. Almeraya, K. YamaguchiShinozaki, and D. Hoisington. 2004. Stress-induced expression in wheat of the Arabidopsis thaliana DREB1A gene delays water stress symptoms under greenhouse conditions. Genome 47:493-500.

Peng, K., D. Jaccoud, D. Kudrna, Y.-G. Cho, and A. Kilian. 2002. Diversity array technology (DART) applications to plant and animal genomics. Plant, Animal, and Microbe Genomes X Conference. Jan. 12-26, 2002, San Diego, CA.

Penmetsa, R. V., and D. R. Cook. 1997. A legume ethylene-insensitive mutant hyperinfected by rhizobial symbiont. Science 275:527-530.

Penmetsa, R. V., J. A. Frugoli, L. S. Smith, S. R. Long, and D. R. Cook. 2003. Dual genetic pathways controlling nodule number in Medicago truncatula. Plant Physiol. 131:998-1008.

Pennuela, S., D. Danesh, and N. D. Young. 2002. Targeted isolation, sequence analysis, and physical mapping of nonTIR NBS-LRR genes in soybean. Theor. Appl. Genet. 104:261-272.

Pereira, M. G., M. M. T. de Sousa, and I. M. Duarte. 2001. Status of European Cicer database. p. 45-46. In: L. Magioni, M. Ambrose, R. Schachl, G. Duc, and E. Lipman (compilers), Report of a Working Group on Grain Legumes. Third Meeting, 5-7 July 2001, Krakow, Poland. IPGRI, Rome, Italy.

Perrin, Y., C. Vaquero, I. Gerrard, M. Sack, J. Drossard, E. Stoger, P. Christou, and R. Fischer. 2000. Transgenic pea seeds as bioreactors for the production of a single-chain Fv fragment ( $\mathrm{scFv}$ ) antibody used in cancer diagnosis and therapy. Biologia Plantarum 43:345-352.

Pfaff, T., and G. Kahl. 2003. Mapping of gene-specific markers on the genetic map of chickpea (Cicer arietinum L.). Mol. Gen. Genom. 269:243-251.

Piao Z. Y., Y. Q. Deng, S. R. Choi, Y. J. Park, and Y. P. Lim. 2004. SCAR and CAPS mapping of $C R b$, a gene conferring resistance to Plasmodiophora brassicae in Chinese cabbage (Brassica rapa ssp. pekinensis). Theor. Appl. Genet. 108:1458-1465.

Pilet-Nayal, M. L., F. J. Muehlbauer, R. J. McGee, J. M. Kraft, A. Baranger, and C. J. Coyne. 2003. Quantitative trait loci for partial resistance to Aphanomyces root rot in pea. Theor. Appl. Genet. 106:28-39.

Podlich, D. W., and M. Cooper. 1998. QU-GENE: a simulation platform for quantitative analysis of genetic models. Bioinformatics 14:632-653.

Podlich, D. W., C. R. Winkler, and M. Cooper. 2004. Mapping as you go: an effective approach for marker-assisted selection of complex traits. Crop Sci. 44:1560-1571. 
Polhill, R. M., and L. J. G. van der Maesen. 1985. Taxonomy of grain legumes. p. 3-36. In: R. J. Summerfield and E. H. Roberts (eds.), Grain legume crops. Collins Professional and Tech. Books, London.

Popelka, J. C., N. Terryn, and T. J. V. Higgins. 2004. Gene technology for grain legumes: can it contribute to the food challenge in developing countries? Plant Sci. 167:195-206.

Popenoe, H., S. R. King, J. Leon, and L. S. Kalinowski. 1989. Lost crops of the Incas. Nat. Acad. Press, Washington, DC, pp. 1-26.

Posa-Macalincag, M. C. T., G. L. Hosfield, K. F. Grafton, M. A. Uebersax, and J. D. Kelly. 2002. Quantitative trait loci (QTL) analysis of canning quality traits in kidney bean (Phaseolus vulgaris L.). J. Am. Soc. Hort. Sci. 127:608-615.

Poulsen, C., and L. Podenphant. 2002. Expressed sequence tags from roots and nodule primordial of Lotus japonicus infected with Mesorhizobium loti. Mol. Plant Microbe Interact. 15:376-379.

Pozarkova, D., A. Koblizkova, B. Roman, A. M. Torres, S. Lucretti, M. Lysak, J. Dolezel, and J. Macas. 2002. Development and characterization of microsatellite markers from chromosome 1-specific DNA libraries of Vicia faba. Biol. Plantarum 45:337-345.

Pratt, R. C., and S. G. Gordon. 1994. Introgression of Phaseolus acutifolius A. Gray genes into the Phaseolus vulgaris L. genome. Plant Breed. 113:137-149.

Pratt, R. C., and G. P. Nabhan. 1988. Evolution and diversity of Phaseolus acutifolius genetic resources. p. 409-440. In: P. Gepts (ed.), Genetic resources of phaseolus beans. Kluwer Academic Publishers, Boston.

Prioul, S., A. Frankewitz, G. Deniot, G. Morin, and A. Baranger. 2004. Mapping of quantitative trait loci for partial resistance to Mycosphaerella pinodes in pea (Pisum sativum L.), at the seedling and adult plant stages. Theor. Appl. Genet. 108:1322-1334.

Pritchard, J. K., M. Stephens, and P. Donnelly. 2000. Inference of population structure using multilocus genotyping data. Genetics 155:945-959.

Pundir, R. P. S., and R. B. Singh. 1985. Biosystematic relationships among Cajanus, Atylosia and Rhynchosia species and evolution of pigeonpea (Cajanus cajan (L.) Millsp.). Theor. Appl. Genet. 69:531-534.

Rachie, K. O., and L. M. Roberts. 1974. Grain legumes of the lowland tropics. Adv. Agron. 26:1-132.

Rafalski, A., and M. Morgante. 2004. Corn and humans: recombination and linkage disequilibrium in two genomes of similar size. Trend Genet. 20:103-111.

Rajesh, P. N., C. Coyne, K. Meksem, K. D. Sharma, V. Gupta, and F. J. Muehlbauer. 2004. Construction of a Hind III bacterial artificial chromosome library and its use in identification of clones associated with disease resistance in chickpea. Theor. Appl. Genet. 108:663-669.

Rajesh, P. N., A. Tullu, J. Gil, V. S. Gupta, P. K. Ranjekar, and F. J. Muehlbauer. 2002. Identification of an STMS marker for the double-podding gene in chickpea. Theor. Appl. Genet. 105:604-607.

Rakshit, S., P. Winter, M. Tekeoglu, J. Jaurez-Munoz, T. Pfaff, A. M. Benko-Iseppon, F. J. Muehlbauer, and G. Kahl. 2003. DAF marker tightly linked to a major locus for Ascochyta blight resistance in chickpea (Cicer arietinum L.). Euphytica 132:23-30.

Ramalingam, J., C. M. V. Cruz, K. Kukreja, J. M. Chittoor, J.-L. Wu, S. W. Lee, M. Baraoidan, M. L. George, M. B. Cohen, S. H. Hulbert, J. E. Leach, and H. Leung. 2003. Candidate defense genes from rice, barley, and maize and their association with qualitative and quantitative resistance in rice. Mol. Plant Microbe Interact. 16:14-24.

Rao, N. K., L. J. Reddy, and P. J. Bramel. 2003. Potential of wild species for genetic enhancement of some semi-arid food crops. Genetic Resour. Crop Evol. 50:707-721. 
Ratnaparkhe, M. B., D. K. Santra, A. Tullu, and F. J. Muehlbauer. 1998. Inheritance of intersimple-sequence-repeat polymorphisms and linkage with a Fusarium wilt resistance gene in chickpea. Theor. Appl. Genet. 96:348-353.

Rava, C. A., J. G. C. de Costa, A. Sartorato, and M. J. de-O-Zimmermann. 1996. Development of dry bean lines resistant to common bacterial blight from a cross between Phaseolus vulgaris and P. acutifolius. Summa-Phytopathologica 22:33-36.

Rava, C. A., A. F. Puricho, and A. Sartorato. 1994. Caracterizacao de patotipos de Colletotrichum lendemuthianum que ocorrem em algumas regioes produtoras de feijoeiro comum. Fitopatol. Bras. 19:167-172.

Raymond, R. 2001. Germplasm flows shown to greatly benefit developing countries. Geneflow. IPGRI, Rome.

Rector, B. G., J. N. All, W. A. Parrott, and H. R. Boerma. 1998. Identification of molecular markers linked to quantitative trait loci for soybean resistance to corn earworm. Theor. Appl. Genet. 96:786-790.

Reddy, L. J. 1990. Pigeonpea morphology. p. 47-87. In: Y. L. Nene, S. D. Hall, and V. K. Sheila (eds.), The pigeonpea. CABI, Wallingford, UK.

Reddy, L. J., N. K. Rao, and K. B. Saxena. 2001. Production and characterization of hybrids between Cajanus cajan $\times$ C. reticulatus var. grandifolius. Euphytica 121:93-98.

Reddy, L. J., H. D. Upadhyaya, C. L. L. Gowda, and S. Singh. 2004. Development of core collection in pigeonpea (Cajanus cajan (L) Millsp.). Genet. Resourc. Crop Evol. (in press).

Reddy, M. V., S. B. Sharma, and Y. L. Nene. 1990. Pigeonpea: Disease management. p. 303-347. In: Y. L. Nene, S. D. Hall, and V. K. Sheila (eds.), The pigeonpea. CABI, Wallingford, UK.

Reiter, R. S., J. G. K. Williams, K. A. Feldmann, J. A. Rafalski, S. V. Tingey, and P. A. Scolnik. 1992. Global and local genome mapping in Arabidopsis thaliana by using recombinant inbred lines and random polymorphic DNAs. Proc. Nat. Acad. Sci. (USA) 89:1477-1481.

Remington, D. L., J. M. Thornsberry, Y. Matsuoka, L. M. Wilson, and S. R. Whitt. 2001. Structure of linkage disequilibrium and phenotypic associations in the maize genome. Proc. Nat. Acad. Sci. (USA) 25:11479-11484.

Reymond, M., B. Muller, A. Leonardi, A. Charcosset, and F. Tardieu. 2003. Combining quantitative trait loci analysis and an ecophysiological model to analyse the genetic variability of the responses of maize leaf growth to temperature and water deficit. Plant Physiol. 131:664-675.

Ribaut, J.-M., and D. Hoisington. 1998. Marker-assisted selection: New tools and strategies. Trends Plant Sci. 3:236-238.

Ribaut, J. M., C. Jiang, D. Gonzalez de Leon, G. O. Edmeades, and D. A. Hoisington. 1997. Identification of quantitative trait loci under drought conditions in tropical maize. Yield components and marker-assisted selection strategies. Theor. Appl. Genet. 94:887-896.

Rick, C. M. 1966. Abortion of male and female gametes in the tomato determined by allelic interactions. Genetics 53:85-96.

Rivkin, M. I., C. E. Vallejos, and P. E. McClean. 1999. Disease-resistance related sequences in common bean. Genome 42:41-47.

Rizhsky, L., H. Liang, and R. Mittler. 2002. The combined effect of drought stress and heat shock on gene expression in tobacco. Plant Physiol. 130:1143-1151.

Robert, V. J. M., M. A. L. West, S. Inai, A. Caines, L. Arntzen, J. K. Smith, and D. A. St. Clair. 2001. Marker-assisted introgression of blackmold resistance QTL alleles from wild Lycopersicon cheesmanii to cultivated tomato (L. esculentum) and evaluation of QTL phenotypic effects. Mol. Breed. 8:217-233. 
Roberts, E. H. 1973. Predicting the storage life of seeds. Seed Sci. Technol. 1:499-514.

Robertson, L. D. 1997. Faba bean. p. 168-180. In: D. Fuccillo, L. Sears, and P. Stapleton (eds.), Biodiversity in trust. Cambridge Univ. Press, UK.

Robertson, L. D., and M. El-Sheerbeeny. 1988. Faba Bean Germplasm Catalog: Pure Line Collection. ICARDA, Aleppo, Syria.

Robertson, L. D., and W. Erskine. 1997. Lentil. p. 128-138. In: D. Fuccillo, L. Sears, and P. Stapleton (eds.), Biodiversity in trust. Cambridge Univ. Press, UK.

Rodino, A. P., M. Santalla, A. M. D. Ron, and S. P. Singh. 2003. A core collection of common bean from the Iberian peninsula. Euphytica 131:165-175.

Roessner, U., A. Luedemann, D. Brust, O. Fiehn, T. Linke, L. Willimitzer, and A. R. Fernie. 2001. Metabolic profiling allows comprehensive phenotyping of genetically or environmentally modified plant systems. Plant Cell 13:11-29.

Roman, B., Z. Satovic, C. M. Avila, D. Rubiales, M. T. Moreno, and A. M. Torres. 2003. Locating genes associated with Ascochyta fabae resistance in Vicia faba. Australian J. Agr. Res. 54:85-90.

Roman, B., Z. Satovic, D. Pozarkova, J. Macas, J. Dolezel, J. I. Cubero, and A. M. Torres. 2004. Development of a composite map in Vicia faba, breeding applications and future prospects. Theor. Appl. Genet. 108:1079-1088.

Roman, B., A. M. Torres, D. Rubiales, J. I. Cubero, and Z. Satovic. 2002. Mapping of quantitative trait loci controlling broomrape (Orobanche crenata Forsk.) resistance in faba bean (Vicia faba L.). Genome 45:1057-1063.

Romeis, J., T. G. Shanower, and A. J. Peter. 1999. Trichomes of pigeonpea (Cajanus cajan (L.) Millsp.) and two wild Cajanus spp. Crop Sci. 39:564-569.

Ruan, Y., J. Gilmore, and T. Conner. 1998. Towards Arabidopsis genome analysismonitoring expression profiles of 1400 genes using cDNA microarrays. Plant J. 15:821833.

Rubio, J., E. Hajji-Moussa, M. Kharrat, M. T. Moreno, T. Millan, and J. Gil. 2003. Two genes and linked RAPD markers involved in resistance to Fusarium oxysporum f. sp. Ciceris race 0 in chickpea. Plant Breed. 122:188-191.

Rudd, S. 2003. Expressed sequence tags: alternative or complement to whole genome sequences. Trends Plant Sci. 8:321-329.

Russelle, M. 2001. Alfalfa. Am. Sci. 89:252-259.

Sabharwal, V., M. S. Negi, S. S. Banga, and M. Lakshmikumaran. 2004. Mapping of AFLP markers linked to seed coat colour loci in Brassica juncea (L.) Czern. Theor. Appl. Genet. 109:160-166.

Sagan, M., D. Morandi, E. Tarenghi, and G. Duc. 1995. Selection of nodulation and mycorhizal mutants in the model plant Medicago truncatula Gaertn after gamma rays mutagenesis. Plant Sci. 111:63-71.

Sanchez, A. C., D. S. Brar, N. Huang, Z. Li, and G. S. Khush. 2000. Sequence tagged site marker-assisted selection for three bacterial blight resistance genes in rice. Crop Sci. 40:792-797.

Sandal, N., L. Krusell, S. Radutoiu, M. Olbryt, A. Pedrosa, S. Stracke, S. Sato, T. Kato, S. Tabata, M. Parniske, A. Bachmair, T. Ketelsen, and J. Stougaard. 2002. A genetic linkage map of the model legume Lotus japonicus and strategies for fast mapping of new loci. Genetics 161:1673-1683.

Sanders, F. E., and P. B. Tinker. 1973. Phosphate flow into mycorhizal roots. Pest. Sci. 4:385-395.

Sanginga, N., K. E. Dashiell, J. Diels, B. Vanlauwe, O. Lyasse, R. J. Carsky, S. Tarawali, B. Asafo-Adjei, A. Menkir, S. Schulz, B. B. Singh, D. Chikoye, D. Keatinge, and R. Ortiz. 2003. Sustainable resource management coupled to resilient germplasm to provide 
new intensive cereal-grain-legume-livestock systems in the dry savanna. Agriculture Ecosystems and Environment 100:305-314.

Santino, A., B. Valsasina, L. Lioi, A. Vitale, and R. Bollini. 1991. Bean (Phaseolus vulgaris L.) seed lectins: a novel electrophoretic variant of arcelin. Plant Physiol. (Life Sciences Advances). 10:7-11.

Santra, D. K., M. Tekeoglu, M. Ratnaparkhe, W. J. Kaiser, and F. J. Muehlbauer. 2000. Identification and mapping of QTL conferring resistance to Ascochyta blight in chickpea. Crop Sci. 40:1606-1612.

Sarker, A., B. Bayaa, and W. Erskine. 2001. Registration of six lentil germplasm lines with resistance to vascular wilt. Crop Sci. 41:1655.

Sato, S., T. Kaneko, Y. Nakamura, E. Asamizu, T. Kato, and S. Tabata. 2001. Structural analysis of a Lotus japonicus genome. I. Sequence features and mapping of fifty-six TAC clones which cover the $5.4 \mathrm{Mb}$ regions of the genome. DNA Res. 8: 311-318.

Sattler, S. E., Z. Cheng, and D. DellaPenna. 2004. From Arabidopsis to agriculture: engineering improved Vitamin E content in soybean. Trends Plant Sci. 9:365-367.

Saxena, K. B., D. G. Faris, U. Singh, and R. V. Kumar. 1987. Relationship between seed size and protein content in newly developed high protein lines of pigeonpea. Plant Foods for Human Nutr. 36:335-340.

Saxena, K. B., and R. V. Kumar. 2003. Development of a cytoplasmic nuclear male sterility system in pigeonpea using C. scarabaeoides (L.) Thouras. Indian J. Genet. 63:225-229.

Saxena, K. B., L. Singh, and R. P. Ariyanagam. 1993. Role of partial cleistogamy in maintaining genetic purity of pigeonpea. Euphytica 66:225-229.

Saxena, K. B., L. Singh, and L. J. Reddy. 1990a. Low natural outcrossing in cleistogamous pigeonpea mutant. Int. Pigeonpea Newslett. 11:9-10.

Saxena, K. B., L. Singh, M. V. Reddy, U. Singh, S. S. Lateef, S. B. Sharma, and P. Remanandan. 1990b. Intraspecies variation in Atylosia scarabaeoides (L.) Benth., a wild relative of pigeonpea (C. cajan (L.) Millsp.). Euphytica 49:185-191.

Saxena, N. P. 2003. Management of drought in chickpea-A holistic approach. p. 103-122. In: N. P. Saxena (ed.), Management of agricultural drought-Agronomic and genetic options. Oxford \& IBH Publishing Co. Pvt. Ltd., New Delhi.

Schauser, L., A. Roussis, J. Stiller, and J. Stougaard. 1999. A plant regulator controlling development of symbiotic root nodules. Nature 402:191-195.

Schena, M., D. Shalon, R. W. Davis, and P. O. Brown. 1995. Quantitative monitoring of gene expression patterns with a complementary DNA microarray. Science 270:467-470.

Schenk, P. M., K. Kazan, I. Wilson, J. P. Anderson, T. Richmond, S. C. Sommerville, and J. M. Manners. 2000. Coordinated plant defense responses in Arabidopsis revealed by microarray analysis. Proc. Nat. Acad. Sci. (USA) 97:11655-11660.

Schinkel, C., and P. Gepts. 1988. Phaseoline diversity in the tepary bean, Phaseolus acutifolius A. Gray. Plant Breed. 101:292-301.

Schinkel, C., and P. Gepts. 1989. Allozyme variability in the tepary bean, Phaseolus acutifolius A. Gray. Plant Breed. 102:182-195.

Schlueter, J. A., P. Dixon, C. Granger, D. Grant, L. Clark, J. J. Doyle, and R. C. Shoemaker. 2004. Mining the ESTs databases to resolve evolutionary events in major crop species. Genome 47:868-876.

Schmid, K. J., T. R. Sorensen, R. Stracke, O. Torjek, T. Altmann, T. Mitchell-Olds, and B. Weisshaar. 2003. Large-scale identification and analysis of genome-wide single nucleotide polymorphisms for mapping in Arabidopsis thaliana. Genome Res. 13:1250-1257. 
Schneider, K. A., M. E. Brothers, and J. D. Kelly. 1997. Marker-assisted selection to improve drought resistance in common bean. Crop Sci. 37:51-60.

Schoen, D. J., J. J. Burdon, and A. H. D. Brown. 1992. Resistance of Glycine tomentella to soybean leaf rust Phakopsora pachyrhizi in relation to ploidy level and geographic distribution. Theor. Appl. Genet. 83:827-832.

Schoonhoven, A. V., C. Cardona, and J. Valor. 1983. Resistance to the bean weevil and Mexican bean weevil (Coleoptera: Bruchidae) in non-cultivated bean accessions. J. Econ. Entomol. 76:1255-1259.

Schultze, M., and A. Kondorosi. 1998. Regulation of symbiotic root nodule development. Annu. Rev. Genet. 32:33-57.

Schuster, M. L., D. P. Coyne, T. Behre, and H. Leyna. 1983. Sources of Phaseolus species resistance and leaf and pod differential reactions to common blight. Hort. Sci. 18:901-903.

Schut, J. W., X. Qi, and P. Stam. 1997. Association between relationship measures based on AFLP markers, pedigree data and morphological traits in barley. Theor. Appl. Genet. 95:1161-1168.

Searle, I. R., A. M. Men, T. S. Laniya, D. M. Buzas, I. Iturbe-Ormaetre, B. J. Carrol, and P. M. Gresshoff. 2003. Long distance signaling for control in legume requires a CLAVATA1-like receptor kinase. Science 299:109-112.

Seki, M., M. Narusaka, H. Abe, M. Kasuga, K. Yamaguchi-Shinozaki, P. Carninci, Y. Hayashizaki, and K. Shinozaki. 2001. Monitoring the expression pattern of 1300 Arabidopsis genes under drought and cold stresses by using a full-length cDNA microarray. Plant Cell 13:61-72.

Serraj, R. (ed.). 2004. Symbiotic nitrogen fixation: Challenges and future prospects for application in tropical agroecosystems. Oxford \& IBH, New Delhi, India.

Serraj, R., L. Krishnamurthy, and H. D. Upadhyaya. 2004. Screening chickpea mini-core germplasm for tolerance to salinity. Intl. Chickpea and Pigeonpea Newsl. 11:29-32.

Sethy, N. K., B. Shokeen, and S. Bhatia. 2003. Isolation and characterization of sequencetagged mircosatellite sites markers in chickpea (Cicer aeritinum L.). Mol. Ecology Notes $3: 428-430$.

Setter, T. L., E. A. Conocono, J. A. Egdane, and M. J. Kropff. 1995. Possibilities of increasing yield potential of rice by reducing panicle height in the canopy: I. Effects of panicles on light interception and canopy photosynthesis. Aust. J. Plant Physiol. 22:441-451.

Shannon, C. E., and W. Weaver. 1949. The mathematical theory of communication. Univ. Illinois Press, Urbana.

Sharma, H. C., G. Pampapathy, and L. J. Reddy. 2003. Wild relatives of pigeonpea as a source of resistance to the podfly (Melalagromyza obtuse Malloch) and pod wasp (Tranaostigmodes cajaninae La Salle). Genet. Resourc. Crop Evol. 50:817-824.

Sharma, K. D., P. Winter, G. Kahl, and F. J. Muehlbauer. 2004. Molecular mapping of Fusarium oxysporum f. sp. ciceris race 3 resistance gene in chickpea. Theor. Appl. Genet. 108:1243-1248.

Sharma, S. B. 1995. Resistance to Rotylenchulus renoformis, Heterodera cajani, and Meloidogyne javanica in accessions of Cajanus platycarpus. Plant Dis. 79:1033-1035.

Sharma, S. B., P. Remanandan, and K. C. Jain. 1993a. Resistance to cyst nematode (Heterodera cajani) in pigeonpea cultivars and wild relatives of Cajanus. Ann. Appl. Biol. 123:75-81.

Sharma, S. B., P. Remanandan, and D. McDonald. 1993b. Resistance to Meloidogyne javanica and Rotylenchulus reniformis in wild relatives of pigeonpea. J. Nematol. 25(4S):824-829. 
Sharma, S. B., R. A. Sikora, N. Greco, M. D. Vito, and G. Caubel. 1994. Screening techniques and sources of resistance to nematodes in cool season food legumes. Euphytica 73:59-66.

Shibata, K., S. Abe, and E. Davies. 2001. Structure of the coding region and mRNA variants of the apyrase gene from pea (Pisum sativum). Acta Physiol. Plant. 23:3-13.

Shim, J. H., J. Chung, and M. S. Go. 2001. Construction of molecular genetic linkage map using RAPD markers in cowpea. Korean J. Crop Sci. 46:341-343.

Shoemaker, R., P. Keim, L. Vodkin, E. Retzel, S. W. Clifton, R. Waterston, D. Smoller, V. Coryell, A. Khanna, J. Erpelding, X. Gai, V. Brendel, C. Raph-Schmidt, E. G. Shoop, C. J. Vielweber, M. Schmatz, D. Pape, Y. Bowers, B. Theising, J. Martin, M. Dante, T. Wylie, and C. Granger. 2002. A compilation of soybean ESTs: generation and analysis. Genome 45:329-338.

Shoemaker, R. C., K. Polzin, J. Labate, J. Specht, E. C. Brummer, T. Olson, N. D. Young, V. Concibido, J. Wilcox, J. P. Tamoulonis. G. Kochert, and H. R. Boerma. 1996. Genome duplication in soybean (Glycine subgenus soja). Genetics 144:329-338.

Shoemaker, R. C., J. A. Schlueter, P. Cregan, and L. Vodkin. 2003. The status of soybean genomics and its role in the development of soybean biotechnologies. AgBioForum $6: 4-7$.

Simko, I., S. Costanzo, K. G. Haynes, B. J. Christ, and R. W. Jones. 2004. Linkage disequilibrium mapping of a Verticillium dahliae resistance quantitative trait locus in tetraploid potato (Solanum tuberosum) through a candidate gene approach. Theor. Appl. Genet. 108:217-224.

Simon, C. J., and R. M. Hannan. 1995. Development and use of core subsets of cool-season food legume germplasm collections. Hort. Sci. 30:907 (Abstr.).

Simon, C. J., and F. J. Muehlbauer. 1997. Construction of a chickpea linkage map and its comparison with maps of pea and lentil. J. Hered. 88:115-119.

Simpson, C. E., and J. L. Starr. 2001. Registration of Coan peanut. Crop Sci. 41:918.

Simpson, C. E., J. L. Starr, G. T. Church, M. D. Burow, and A. H. Paterson. 2003. Registration of 'Nema TAM' peanut. Crop Sci. 43:1561.

Singh, A. K., and C. E. Simpson. 1994. Biosystematics and genetic resources. p. 96-137. In: J. Smart (ed.), The groundnut crop: A scientific basis for crop improvement. Chapman and Hall, London.

Singh, B. B., H. A. Ajeigbe, S. A. Tarawali, S. Fernandez-Rivera, and M. Abubakar. 2003a. Improving the production and utilization of cowpea as food and fodder. Field Crops Res. 84:169-177.

Singh, B. B., P. Hartmann, C. Fatokun, M. Tamo, S. Tarawali, and R. Ortiz. 2003b. Recent progress on cowpea improvement. Chronica Hort. 43:8-12.

Singh, B. B., F. Hakizimana, E. A. Kueneman, and R. Ortiz. 2004. Soybean production and utilization in Africa. p. 56-70. In: F. Moscardi, C. B. Hoffman-Campo, O. Ferreira Saraiva, P. R. Galerani, F. C. Krzyzanowski, and M. C. Carrao-Panizzi (eds.), Proc. VII World Soybean Research Conf.-VI Intl. Soybean Processing and Utilization Conf.-III Congreso Brasileiro de Soja. Foz de Iguazu, PR, Brazil, 29 February-5 March 2004. Brazilian Agricultural Research Corporation-National Soybean Research Center, Min. Agric., Livestock and Food Supply, Londrina, PR, Brazil.

Singh, B. V., and M. R. Ahuja. 1977. Phaseolus sublobata Roxb. A source of resistance to yellow mosaic virus for cultivated mungbean. Indian J. Genet. 37:130-132.

Singh, K. B., R. S. Malhotra, M. H. Halia, E. J. Kinghts, and M. M. Varma. 1994. Current status and future strategy in breeding chickpea for resistance to biotic and abiotic stresses. Euphytica 73:137-149. 
Singh, K. B., and B. Ocampo. 1997. Exploitation of wild Cicer species for yield improvement in chickpea. Theor. Appl. Genet. 95:418-423.

Singh, R. J., K. P. Kollipara, and T. Hymowitz. 1993. Backcross $\left(\mathrm{BC}_{2}-\mathrm{BC}_{4}\right)$-derived fertile plants from Glycine $\max$ and G. tomentella intersubgeneric hybrids. Crop Sci. 33:1002-1007.

Singh, S. P. 1992. Common bean improvement in the tropics. Plant Breed. Rev. 20:199269.

Singh, S. P. 2001. Broadening the genetic base of common bean cultivars: A review. Crop Sci. 41:1659-1675.

Singh, S. P., D. G. Debouck, and W. M. Roca. 1997. Successful interspecific hybridization between Phaseolus vulgaris L. and P. costaricensis Freytag and Debouck. Annu. Rpt. Bean Improv. Coop. 40:40-41.

Singh, S. P., P. Gepts, and D. G. Debouck. 1991. Races of common bean (Phaseolus vulgaris Fabaceae). Eco. Bot. 45:379-396.

Singh, S. P., A. Molina, and P. Gepts. 1995. Potential of wild common bean for seed yield improvement of cultivars in the tropics. Can. J. Plant Sci. 75:807-813.

Siriwardhane, D., Y. Egawa, and N. Tomooka. 1991. Cross-compatibility of cultivated adzuki bean (Vigna angularis) and rice bean (Vigna umbellata) with their wild relatives. Plant Breed. 107:320-325.

Skiba, B., R. Ford, and E. C. K. Pang. 2003. Amplification and detection of polymorphic sequence-tagged sites in Lathyrus sativus. Plant Mol. Biol. Reptr. 21:391-404.

Skiba, B., R. Ford, and E. C. K. Pang. 2004. Construction of a linkage map based on a Lathyrus sativus backcross population and preliminary investigation of QTLs associated with resistance to ascochyta blight, Theor. Appl. Genet. 109:1726-1735.

Skot, L., N. R. S. Hamilton, S. Mizen, K. H. Chorlton, and I. D. Thomas. 2002. Molecular genecology of temperature response in Lolium perenne: 2. Association of AFLP markers with ecogeography. Mol. Ecology 11:1865-1876.

Smartt, J. 1988. Morphological, physiological and biochemical changes in Phaseolus beans under domestication. p. 143-161. In: P. Gepts (ed.), Genetic resources of Phaseolus beans. Kluwer, Dordrecht, The Netherlands.

Smartt, J. 1990. The pigeonpea (Cajanus cajan (L.) Millsp.). p. 278-293. In: Grain Legumes: evolution and genetic resources. Cambridge Univ. Press, Cambridge, UK.

Smith, J. M. 1999. The detection and measurement of recombination from sequence data. Genetics 153:1021-1027.

Soleimani, V. D., B. R. Baum, and D. A. Johnson. 2002. AFLP and pedigree-based genetic diversity estimates in modern cultivars of durum wheat [Triticum turgidum L. subsp. Durum (Desf.) Husn.]. Theor. Appl. Genet. 104:350-357.

Song, Q. J., L. F. Marek, R. C. Shoemaker, K. G. Lark, V. C. Concibido, X. Delannay, J. E. Specht, and P. B. Cregan. 2004. A new integrated genetic linkage map of the soybean. Theor. Appl. Genet. 109:122-128.

Souframanien, J., J. G. Manjaya, T. G. Krishna, and S. E. Pawar. 2003. Random amplified polymorphic DNA analyses of cytoplasmic male sterile and male fertile pigeonpea (Cajanus cajan (L.) Millsp.). Euphytica 129:293-299.

Souza, A. A., R. L. Boascaiol, D. H. Moon, L. E. A. Camargo, and S. M. Tsai. 2000. Effects of Phaseolus vulgaris QTL in controlling host-bacteria interactions under two levels of nitrogen fertilization. Genet. Mol. Biol. 23:155-161.

Specht, J. E., K. Chase, M. Macrander, G. L. Graef, J. Chung, J. P. Markwell, M. Germann, J. H. Orf, and K. G. Lark. 2001. Soybean response to water: A QTL analysis of drought tolerance. Crop Sci. 41:493-509. 
Stacey, G., and H. Nguyen. 2004. Mapping and sequencing the soybean genome. p. 234254. In: R. F. Wilson, H. T. Stalker, and E. C. Brummer (eds.), Legume crop genomics. AOCS Press, Champaign, Illinois.

Stalker, H. T. 1980. Utilization of wild species for crop improvement. Adv. Agron. 33:111-147.

Stam, P., and A. C. Zeven. 1981. The theoretical proportion of the donor genome in nearisogenic lines of self-fertilizers bred by backcrossing. Euphytica 30:227-238.

Stamigna, C., P. Crino, and F. Saccardo. 2000. Wild relatives of chickpea: multiple disease resistance and problems to introgression in the cultigen. J. Genet. Breed. 54:213-219.

Stark, A., and Z. Madar. 2002. Phytoestrogens: a review of recent findings. J. Ped. Endocrin Metab. 15:561-572.

Stevenson, P. C., and M. P. Haware. 1999. Maackiain in Cicer bijugum Rech. F. associated with resistance to Bortrytis gray mould. Biochem. System. Ecol. 27:761-767.

Stracke, S., C. Kistner, S. Yoshida, I. Mulder, S. Sato, T. Kaneko, S. Tabata, N. Sandal, J. Stougaard, K. Szczyglowski, and M. Parniske. 2002. A plant receptor-like kinase required for both bacterial and fungal symbiosis. Nature 417:959-962.

Stracke, S., S. Sato, N. Sandal, M. Koyama, T. Kaneko, S. Tabata, and M. Parniske. 2004. Exploitation of collinear relationships between the genomes of Lotus japonicus, Pisum sativum, and Arabidopsis thaliana, for positional cloning of a legume symbosis gene. Theor. Appl. Genet. 108:442-449.

Subbarao, G. V., C. Johansen, M. K. Jana, and J. D. V. K. Rao. 1991. Comparative salinity responses among pigeonpea genotype and their wild relatives. Crop Sci. 31:415-418.

Subbarao, G. V., C. Johansen, J. D. V. K. Rao, and M. K. Jana. 1990. Salinity tolerance in F1 hybrids of pigeonpea and a tolerant wild relative. Crop Sci. 30:785-788.

Sun, G., M. Bond, H. Nass, R. Martin, and Z. Dong. 2003. RAPD polymorphisms in spring wheat cultivars and lines with different levels of Fusarium resistance. Theor. Appl. Genet. 106:1059-1067.

Sun, G. L., M. William, J. Liu, K. J. Kasha, and K. P. Pauls. 2001. Microsatellite and RAPD polymorphisms in Ontario corn hybrids are related to the commercial sources and maturity ratings. Mol. Breed. 7:13-24.

Suzuki, M. 2003. Simple methods for storing soybean seeds in the tropics. AVRDC Progress Rep. 2002. pp. 146-147.

Szczyglowski, K., D. Hamburger, P. Kapranov, and F. J. de Bruijin. 1997. Construction of a Lotus japonicus late nodulin expressed sequence tag library and identification of novel nodule-specific genes. Plant Physiol. 114:1335-1346.

Tamulonis, J. P., B. M. Luzzi, R. S. Hussey, W. A. Parrott, and H. R. Boerma. 1997a. DNA markers associated with resistance to Javanese root-knot nematode in soybean. Crop Sci. 37:783-788.

Tamulonis, J. P., B. M. Luzzi, R. S. Hussey, W. A. Parrott, and H. R. Boerma. 1997b. DNA marker analysis of loci conferring resistance to peanut root-knot nematode in soybean. Theor. Appl. Genet. 95:664-667.

Tanksley, S. D., M. W. Ganal, J. P. Prince, M. C. de Vicent, M. W. Bonierbale, P. Broun, T. M. Fulton, J. J. Giovannoni, S. Grandillo, G. B. Martin, R. Messeguer, J. C. Miller, L. Miller, A. H. Paterson, O. Pineda, M. S. Roder, R. A. Wing, W. Wu, and N. D. Young. 1992. High density molecular linkage maps of the tomato and potato genomes. Genetics 132:1141-1160.

Tanksley, S. D., and S. R. McCouch. 1997. Seed banks and molecular maps: unlocking genetic potential from the wild. Science 277:1063-1066. 
Tanksley, S. D., and J. C. Nelson. 1996. Advance backcross QTL analysis: a method for the simultaneous discovery and transfer of valuable QTL from unadapted germplasm to the elite breeding lines. Theor. Appl. Genet. 92:191-203.

Tanksley, S. D., N. D. Young, A. H. Paterson, and M. W. Bonierbale. 1989. RFLP mapping in plant breeding: new tools for an old science. BioTechnology 7:257-264.

Tao, Q., Y. L. Chang, J. Wang, H. Chen, M. N. Islam-Faridi, C. Scheuring, B. Wang, D. M. Stelly, and H.-B. Zhang. 2001. BAC-based physical map of the rice genome constructed by restriction fingerprint analysis. Genetics 158:1711-1724.

Tar'an, B., T. E. Michaels, and K. P. Pauls. 2003a. Marker-assisted selection for complex trait in common bean (Phaseolus vulgaris L.) using QTL-based index. Euphytica 130:423-443.

Tar'an, B., T. Warkentin, D. J. Somers, D. Miranda, A. Vandenberg, S. Blade, S. Woods, D. Bing, A. Xue, D. Dekoeyer, and G. Penner. 2003b. Quantitative trait loci for lodging resistance, plant height, and partial resistance to mycosphaerella blight in field pea (Pisum sativum L.). Theor. Appl. Genet. 107:1482-1491.

Tar'an, B., L. Buchwaldt, A. Tullu, S. Banniza, T. D. Warkentin, and A. Vandenberg. 2003c. Using molecular markers to pyramid genes for resistance to ascochyta blight and anthracnose in lentil (Lens culinaris Medik). Euphytica 134:223-230.

Tar'an, B., T. E. Michaels, and K. P. Pauls. 1998. Stability of the association of molecular markers with common bacterial blight resistance in common bean (Phaseolus vulgaris L.). Plant Breed. 117:553-558.

Tar'an, B., T. E. Michaels, and K. P. Pauls. 2001. Mapping genetic factors affecting the reaction to Xanthomonas axonopodis pv. phaseoli in Phaseolus vulgaris L. under field conditions. Genome 44:1046-1056.

Tar'an, B., T. E. Michaels, and K. P. Pauls. 2002. Genetic mapping of agronomic traits in common bean. Crop Sci. 42:544-556.

Tar'an, B., T. Warkentin, D. J. Somers, D. Miranda, A. Vandenberg, S. Blade, and D. Bing. 2004. Identification of quantitative trait loci for grain yield, seed protein concentration and maturity in field pea (Pisum sativum L.). Euphytica 136:297-306.

Tardieu. F. 2003. Virtual plants: modeling as a tool for the genomics of tolerance to water deficit. Trends Plant Sci. 8:9-14.

Tasma, I. M., L. L. Lorenzen, D. E. Green, and R. C. Shoemaker. 2001. Mapping genetic loci for flowering time, maturity, and photoperiod insensitivity in soybean. Mol. Breed. 8:25-35.

Tateishi, Y. 1996. Systematics of the species of Vigna subgenus Ceratotropis. p. 9-24. In: Mungbean germplasm: Collection, evaluation, and utilization for breeding program. JIRCAS Working Report No. 2. Japan International Research Centre for Agricultural Sciences (JIRCAS), Japan.

Tatineni, V., R. G. Cantrell, and D. D. Davis. 1996. Genetic diversity in elite cotton germplasm determined by morphological characteristics and RAPDs. Crop Sci. 36:186-192.

Tekeoglu, M., P. N. Rajesh, and F. J. Muehlbauer. 2002. Integration of sequence tagged microsatellites to the chickpea genetic map. Theor. Appl. Genet. 105:847-854.

Tekeoglu, M., A. Tullu, W. J. Kaiser, and F. J. Muehlbauer. 2000. Inheritance and linkage of two genes that confer resistance to Fusarium wilt in chickpea. Crop Sci. 40:12471251.

The International SNP Map Working Group. 2001. A map of human genome sequence variation containing 1.42 million single nucleotide polymorphisms. Nature 409:928-933. 
Thibaud-Nissen, F., R. T. Shealy, A. Khanna, and L. O. Vodkin. 2003. Clustering of microarray data reveals transcript patterns associated with somatic embryogenesis in soybean. Plant Physiol. 132:118-136.

Thomas, W. T. B. 2003. Prospects for molecular breeding of barley. Ann. Appl. Biol. 142:1-12.

Thoquet, P., M. Gherardi, E.-P. Journet, A. Kereszt, J.-M. Ane, J.-M. Prosperi, and T. Huguet. 2002. The molecular genetic linkage map of model legume Medicago truncatula: an essential tool for comparative legume genomics and the isolation of agronomically important genes. BMC Plant Biol. 2:1-13 (http://www.biomedcentral.com/1471-2229/ $2 / 1)$.

Thornsberry, J. M., M. M. Goodman, J. Doebley, S. Kresovich, D. Nielsen, and E. S. Buckler IV. 2001. Dwarf8 polymorphisms associate with variation in flowering time. Nature Genet. 28:286-289.

Thro, A. M., W. Parrott, J. A. Udall, and W. D. Beavis (editors). 2004. Genomics and plant breeding: the experience of the initiative for future agricultural and food systems. Crop Sci. 44:1893-1919.

Thu-Hang, P., L. Bassie, G. Sawfat, P. Trung-Nghia, and T. Capell. 2002. Expression of heterologous $S$-Adenosylmethionine decarboxylase cDNA in plants demonstrates that changes in S-adenosyl-L-methionine decarboxylase activity determine levels of the higher polyamines spermidine and spermine. Plant Physiol. 129:1744-1754.

Tian, A.-G., J. Wang, P. Cui, Y.-J. Han, H. Xu, L.-J. Cong, X.-G. Huang, X.-L. Wang, Y.-Z. Jiao, B.-J. Wang, Y.-J. Wang, J.-S. Zhang, and S.-Y. Chen. 2004. Characterization of soybean genomic features by analysis of its expressed sequence tags. Theor. Appl. Genet. 108:903-913.

Timmerman-Vaughman, G. M., T. J. Frew, R. Butler, S. Murray, M. Gilpin, K. Falloon, P. Johnston, M. B. Lakeman, A. Russell, and T. Khan. 2004. Validation of quantitative trait loci for ascochyta blight resistance in pea (Pisum sativum L.), using populations from two crosses. Theor. Appl. Genet. 109:1620-1631.

Timmerman-Vaughman, G. M., T. J. Frew, A. L. Miller, N. F. Weeden, and W. A. Jermyn. 1993. Linkage mapping of $s b m-1$, a gene conferring resistance to pea seed-born mosaic virus using molecular markers in Pisum sativum. Theor. Appl. Genet. 85:609-615.

Timmerman-Vaughan, G. M., T. J. Frew, A. C. Russell, T. Khan, R. Butler, M. Gilpin, S. Murray, and K. Falloon. 2002. QTL mapping of partial resistance to field epidemics of Ascochyta blight of pea. Crop Sci. 42:2100-2111.

Timmerman-Vaughan, G. M., J. A. McCallum, T. J. Frew, N. F. Weeden, and A. C. Russell. 1996. Linkage mapping of quantitative trait loci controlling seed weight in pea (Pisum sativum L.). Theor. Appl. Genet. 93:431-439.

Tiwari, K. R, G. A. Penner, and T. D. Warkentin. 1998. Identification of coupling and repulsion phase RAPD markers for powdery mildew resistance gene er-1 in pea. Genome 41:440-444.

Tohme, J., O. D. Gonzalez, S. Beebe, and M. C. Duque. 1996. AFLP analysis of gene pools of a wild bean core collection. Crop Sci. 36:1375-1384.

Tohme, J., P. Jones, S. Beebe, and M. Iwanaga. 1995. The combined use of agroecological and characterization data to establish the CIAT Phaseolus vulgaris core collection. p. 95-107. In: T. Hodgkin, A. H. D. Brown, T. J. L. van Hintum, and E. A. V. Morales (eds.), Core collections of plant genetic resources. J. Wiley, Chichester, UK.

Tomooka, N., Y. Egawa, C. Lairungreang, and C. Thavarasook. 1992. Collection of wild Ceratotropis species on the Nansei Archipelago, Japan, and evaluation of bruchid resistance. Japan. J. Agr. Res. Quart. 26:222-230. 
Tomooka, N., K. Kashiwaba, D. A. Vaughan, M. Ishimoto, and E. Yoshinobu. 2000. The effectiveness of evaluating wild species: searching for sources of resistance to bruchid beetles in the genus Vigna subgenus Ceratotropis. Euphytica 115:27-41.

Topfer, R., N. Martini, and J. Schell. 1995. Modification of plant lipid synthesis. Science 268:681-686.

Torjek, O., D. Berger, R. C. Meyer, C. Mussig, K. J. Schmid, R. Sorense, B. Weisshaar, T. Mitchell-Olds, and T. Altmann. 2003. Establishment of a high efficiency SNP-based framework marker set for Arabidopsis. Plant J. 36:122-140.

Toro, O., J. Tohme, and D. G. Debouck. 1990. Wild beans (Phaseolus vulgaris L.): description and distribution. IBPGR and CIAT, Cali, Colombia.

Torres, A. M., N. F. Weeden, and A. Martin. 1993. Linkage among isozyme, RFLP, and RAPD markers in Vicia faba. Theor. Appl. Genet. 85:937-945.

Trieu, A. T., S. H. Burleigh, I. V. Kardailsky, I. E. Maldonado-Mendoza, W. K. Versaw, L. A. Blaylock, H. Shin, T.-J. Chiou, H. Katagi, G. R. Dewbre, D. Weigel, and M. J. Harrison. 2000. Transformation of Medicago truncatula via infiltration of seedlings or flowering plants with Agrobacterium. Plant J. 22:531-541.

Trinh, T. H., P. Ratet, E. Kondorosi, P. Durand, K. Kamate, P. Bauer, and A. Kondorosi. 1998. Rapid and efficient transformation of diploid Medicago truncatula and Medicago sativa ssp falcate lines improved in somatic embryogenesis. Plant Cell Rep. 17:345-355.

Trung-Nghia, P., L. Bassie, G. Safwat, P. Thu-Hang, O. Lepri, P. Christou, and T. Capell. 2003. Reduction in endogenous arginine decarboxylase transcript levels in rice leads to depletion of the putrescine and supermidine pools with no concomitant changes in the expression of downstream genes in the polyamine biosynthetic pathway. Planta 218:125-134.

Tsai, S. M., R. O. Nodari, D. H. Moon, L. E. A. Camargo, R. Vencovsky, and P. Gepts. 1998. QTL mapping for nodule number and common bacterial blight in Phaseolus vulgaris L. Plant and Soil 204:135-145.

Tullu, A., L. Buchwaldt, T. Warkentin, B. Taran, and A. Vandenberg. 2003. Genetics of resistance to anthracnose and identification of AFLP and RAPD markers linked to the resistance gene in PI 320937 germplasm of lentil (Lens culinaris Medikus). Theor. Appl. Genet. 106:428-434.

Tullu, A., I. Kusmenoglu, K. E. McPhee, and F. J. Muehlbauer. 2001. Characterization of core collection of lentil germplasm for phenology, morphology, seed and straw yields. Genet. Resourc. Crop Evol. 48:143-164.

Tullu, A., F. J. Muehlbauer, C. J. Simon, M. S. Mayer, J. Kumar, W. J. Kaiser, and J. M. Kraft. 1998. Inheritance and linkage of a gene for resistance to race 4 of fusarium wilt and RAPD markers in chickpea. Euphytica 102:227-232.

Turpeinen, T., T. Tenhola, O. Manninen, E. Nevo, and E. Nissila. 2001. Microsatellite diversity associated with ecological factors in Hordeum spontaneum populations in Israel. Mol. Ecol. 10:1577-1591.

Tuvesson, S., L. V. Post, R. Ohlund, P. Hagberg, A. Graner, S. Svitashev, M. Schehr, and R. Elovsson. 1998. Molecular breeding for the BaMMV/BaYMV resistance gene $\mathrm{ym}^{4}$ in winter barley. Plant Breed. 117:19-22.

Ubi, B. E., H. Mignouna, and G. Thottapilly. 2000. Construction of a genetic linkage map and QTL analysis using a recombinant population derived from an intersubspecific cross of cowpea (Vigna unguiculata (L.) Walp.). Breed. Sci. 50:161-172.

Udupa, S. M., and M. Baum. 2003. Genetic dissection of pathotype-specific resistance to ascochyta blight disease in chickpea (Cicer arietinum L.) using microsatellite markers. Theor. Appl. Genet. 106:1196-1202. 
Udvardi, M. K. 2002. Legume genomes and discoveries in symbiosis research. Genome Biology 3(9):reports4028.1-4028.3.

Upadhyaya, H. D., P. J. Bramel, and S. Singh. 2001a. Development of a chickpea core subset using geographic distribution and quantitative traits. Crop Sci. 41:206-210.

Upadhyaya, H. D., S. N. Nigam, and S. Singh. 2001b. Evaluation of groundnut core collection to identify sources of tolerance to low temperature at germination. Indian J. Plant Genet. Resourc. 14:165-167.

Upadhyaya, H. D., R. Ortiz, P. J. Bramel, and S. Singh. 2001c. Development of a groundnut core collection from Asia region. p. 43-44. In: M. C. Kharakwal and R. B. Mehra (eds.), Proc. Diamond Jubilee Symposium. Hundred years of Post-Mendelian Genetics and Plant Breeding-Retrospect and Prospects. November 6-9, 2001. Indian Society of Genetics and Plant Breeding, New Delhi, India.

Upadhyaya, H. D., P. J. Bramel, R. Ortiz, and S. Singh. 2002. Developing a mini core of peanut for utilization of genetic resources. Crop Sci. 42:2150-2156.

Upadhyaya, H. D., and R. Ortiz. 2001. A mini core subset for capturing diversity and promoting utilization of chickpea genetic resources. Theor. Appl. Genet. 102:1292-1298.

Upadhyaya, H. D., R. Ortiz, P. J. Bramel, and S. Singh. 2003. Development of a groundnut core collection using taxonomical, geographical and morphological descriptors. Genet. Resourc. Crop Evol. 50:139-148.

Upadhyaya, H. D., B. P. M. Swamy, P. V. K. Goudar, B. Y. Kullaswamy, and S. Singh. 2004. Identification of diverse groundnut germplasm through multienvironment evaluation of a core collection for Asia. Field Crops Res. (in press).

Urrea, C. A., P. N. Miklas, J. S. Beaver, and R. H. Riley. 1996. A codominant randomly amplified polymorphic DNA (RAPD) marker useful for indirect selection of bean golden mosaic virus resistance in common bean. J. Am. Soc. Hort. Sci. 121:1035-1039.

USDA. 1998. Descriptors for Phaseolus. United States Department of Agriculture, Washington, DC, USA.

Vallejos, C. E., N. S. Sakiyama, and C. D. Chase. 1992. A molecular marker-based linkage map of Phaseolus vulgaris L. Genetics 131:733-740.

van der Maesen, L. J. G. 1985. Cajanus D.C. and Atylosia W. \& A. (Leguminosae). Agricultural University Wageningen Papers 85-4 (1985), The Netherlands.

van der Maesen, L. J. G. 1987. Origin, history, and taxonomy of chickpea. p. 11-43. In: M. C. Saxena and K. B. Singh (eds.), The Chickpea CAB International, Wallingford, UK. van Hintun, Th. J. L., I. W. Boukema, and D. L. Visser. 1996. Reduction of duplication in a Brassica oleracea germplasm collection. Genet. Resourc. Crop Evol. 43:343-349.

van Hintun, Th. J. L., and H. Knupffer. 1995. Duplication within and between germplasm collections. I. Identification of duplication on the basis of passport data. Genet. Resourc. Crop Evol. 42:127-133.

van Hintun, Th. J. L., and D. L. Visser. 1995. Duplication within and between germplasm collections. II. Duplication in four European barley collections. Genet. Resourc. Crop Evol. 42:135-145.

van Treuren, R., L. J. M. van Soest, and Th. J. L. van Hintun. 2001. Marker-assisted rationalization of genetic resource collections: a case study in flax using AFLPs. Theor. Appl. Genet. 103:144-152.

VandenBosch, A., and G. Stacey. 2003. Summaries of the legume genomics projects from around the globe: Community resources for crops and models. Plant Physiol. 131: 840-865.

Vanhouten, W., and S. MacKenzie. 1999. Construction and characterization of a common bean bacterial artificial chromosome library. Plant Mol. Biol. 40:977-983. 
Vavilov, N. I. 1926. The origin, variation, immunity, and breeding of cultivated plants. Chronica Bot. 13:1-194.

Vaz-Patto, M. C., A. M. Torres, A. Koblizkova, J. Macas, and J. I. Cubero. 1999. Development of a genetic composite map of Vicia faba using $\mathrm{F}_{2}$ populations derived from trisomic plants. Theor. Appl. Genet. 98:736-743.

Verulkar, S. B., D. P. Singh, and A. K. Bhattacharya. 1997. Inheritance of resistance to podfly and podborer in the interspecific cross of pigeonpea. Theor. Appl. Genet. 95:506-508.

Virk, P. S., B. V. Ford-Lloyd, M. T. Jackson, H. S. Pooni, T. P. Clemeno, and H. J. Newbury. 1996. Predicting quantitative variation within rice germplasm using molecular markers. Heredity 76:296-304.

Virk, P. S., H. J. Newbury, M. T. Jackson, and B. V. Ford-Lloyd. 1995. The identification of duplicate accessions within a rice germplasm collection using RAPD analysis. Theor. Appl. Genet. 90:1049-1055.

Vishnyakova, M., and A. Omelchenko. 2001. Status of the European Glycine database. p. 60-61. In: L. Magioni, M. Ambrose, R. Schachl, G. Duc, and E. Lipman (compilers), Report of a Working Group on Grain Legumes. Third Meeting, 5-7 July 2001, Krakow, Poland. IPGRI, Rome, Italy.

Vision, T. J., D. G. Brown, and S. D. Tanksley. 2000. The origin of genomic duplications in Arabidopsis. Science 290:2114-2117.

Vito, M., K. B. Singh, N. Greco, and M. C. Saxena. 1996. Sources of resistance to cyst nematode in cultivated and wild Cicer species. Genet. Resourc. Crop Evol. 43:103-107.

Vos, P., R. Hogers, M. Bleeker, M. Reijans, T. van de Lee, M. Hornes, A. Frijters, J. Pot, J. Peleman, and M. Kuiper. 1995. AFLP: A new technique for DNA fingerprinting. Nucl. Acids Res. 23:4407-4414.

Voysest, O. 2000. Mejoramiento genético del frijol (Phaseolus vulgaris L.): Legado de variedades de América Latina 1930-1999. CIAT, Cali, Colombia.

Voysest, O., and M. Desert. 1991. Bean cultivars: classes and commercial seed types. p. 119-162. In: A. van Schoonhoven and O. Voysest (eds.), Common beans: Research for crop improvement. CABI, Wallingford, UK, and CIAT, Cali, Colombia.

Walker, D., H. R. Boerma, J. All, and W. Parrott. 2002. Combining cry1Ac with QTL alleles from PI 229358 to improve soybean resistance to lepidopteran pests. Mol. Breed. 9:43-51.

Wang, D., P. R. Arelli, R. C. Shoemaker, and B. W. Diers. 2001a. Loci underlying resistance to race 3 of soybean cyst nematode in Glycine soja plant introduction 468916. Theor. Appl. Genet. 103:561-566.

Wang, D., G. L. Graef, A. M. Procopiuk, and B. W. Diers. 2004b. Identification of putative QTL that underlie yield in interspecific soybean backcross populations. Theor. Appl. Genet. 108:458-467.

Wang, E., M. J. Robertson, G. L. Hammer, P. S. Carberry, D. Holzworth, H. Meinke, S. C. Chapman, J. N. G. Hargreaves, N. I. Huth, and G. McLean. 2002. Development of a generic crop model template in the cropping system model APSIM. Eur. J. Agron. 18:121-140.

Wang, G., D. J. Mackill, M. J. Bonman, S. R. McCouch, and R. J. Nelson. 1994. RFLP mapping of genes conferring complete and partial resistance to blast in a durably resistant rice cultivar. Genetics 136:1421-1434.

Wang, J., M. van Ginkel, R. Trethowan, G. Ye, I. DeLacy, D. Podlich, and M. Cooper. 2004c. Simulating the effects of dominance and epistasis on selection response in the CIMMYT wheat breeding program using QuCim. Crop Sci. 44:2006-2018.

Wang, M. L., A. G. Gillaspie, M. L. Newman, R. E. Dean, R. N. Pittman, J. B. Morris, and G. A. Pederson. 2004a. Transfer of simple sequence repeat (SSR) markers across the 
legume family for germplasm characterization and evaluation. Plant Genet. Resourc.: Characterization and Utilization 2:107-119.

Wang, R. C., K. Guegler, S. T. LaBrie, and N. M. Crawford. 2000. Genome analysis of a nutrient response in Arabidopsis reveals diverse expression patterns and novel metabolic and potential regulatory genes induced by nitrate. Plant Cell 12:1491-1509.

Webb, D. M., B. M. Baltazar, A. P. Rao-Arelli, J. Schupp, K. Clayton, P. Keim, and W. D. Beavis. 1995. Genetic mapping of soybean cyst nematode race-3 resistance loci in the soybean PI 437.654. Theor. Appl. Genet. 91:574-581.

Weeden, N. F., and F. J. Muehlbauer. 2004. Genomics and genetic improvement in the cool season pulse crops pea, lentil, and chickpea. p. 83-96. In: R. F. Wilson, H. T. Stalker, and E. C. Brummer (eds.), Legume crop genomics. AOCS Press, Champaign, Illinois.

Weeden, N. F., F. J. Muehlbauer, and G. Ladizinsky. 1992. Extensive conservation of linkage relationships between pea and lentil genetic maps. J. Hered. 83:123-129.

Weir, C. C. 1972. Phosphate studies on the Jamaican bauxite soils. Tropical Agric. 49:89-96.

Weir, C. C. 1977. Phosphate fixation in Jamaican latosolic soils. Proc. Amer. Soil Sci. Soc. USA 30:653-655.

Welch, R. M., W. A. House, S. Beebe, and Z. Cheng. 2000. Genetic selection for enhanced bioavailable levels of iron in bean (Phaseolus vulgaris L.) seeds. J. Agr. Food Chem. 48:3576-3580.

White, J. A., J. Todd, T. Newman, N. Focks, T. Girke, O. M. de Ilarduya, J. G. Jaworski, J. B. Ohlrogge, and C. Benning. 2000. A new set of Arabidopsis expressed sequence tags from developing seeds. The metabolic pathway from carbohydrates to seed oil. Plant Physiol. 124:1582-1594.

Wicking, C., and B. Williamson. 1991. From linked markers to gene. Trends Genet. $7: 288-293$.

Wilson, R. F., W. P. Novitzky, and G. P. Fenner. 1995. Effect of fungal damage on seed composition and quality of soybean. Am. Oil Chem. Soc. 72:1425-1429.

Winter, P., A. M. Benko-Iseppon, B. Huttel, M. Ratnaparkhe, A. Tullu, G. Sonnante, T. Pfaff, M. Tekeoglu, D. Santra, V. J. Sant, P. N. Rajesh, G. Kahl, and F. J. Muehlbauer. 2000. A linkage map of chickpea (Cicer arietinum L.) genome based on recombinant inbred lines from a $C$. arietinum $\times C$. reticulatum cross: localization of resistance genes for Fusarium wilt races 4 and 5. Theor. Appl. Genet. 101:1155-1163.

Winter, P., T. Pfaff, S. M. Udupa, B. Huttel, P. C. Sharma, S. Sahi, R. Arreguin-Espinoza, F. Weigand, F. J. Muehlbauer, and G. Kahl. 1999. Characterization and mapping of sequence-tagged microsatellite sites in the chickpea (Cicer arietinum L.) genome. Mol. Gen. Genet. 262:90-101.

Winter, P., C. Staginnus, J. R. Huettel, T. Pfaff, A.-M. Benko-Iseppon, S. Rakshit, S. Pinkert, M. Baum, and G. Kahl. 2003. Architecture and maps of the chickpea genome: a basis for understanding plant-rhizobium interactions. p. 201-222. In: R. Serraj (ed.), Symbiotic nitrogen fixation: Prospects for enhanced application in tropical agriculture. Oxford and IBH Publ. Co. Pvt. Ltd., New Delhi.

Wodicka, L., H. Dong, M. Mittmann, M. H. Ho, and D. J. Lockhart. 1997. Genome-wide expression monitoring in Saccharomyces cerevisiae. Nature Biotechnol. 15:1359-1367.

Wojciechowski, M. F. 2003. Restructuring the phylogeny of legumes (Leguminosae): an early 21st century perspective. In: B. B. Klitgaard and A. Bruneau (eds.), Advances in legume systematics, Part 10. Royal.

Woo, S. S., J. Jiang, B. S. Gill, A. H. Paterson, and R. A. Wing. 1994. Construction and characterization of a bacterial artificial chromosome library of Sorghum bicolor. Nucleic Acids Res. 22:4922-4931. 
Wrather, J. A., T. R. Anderson, D. M. Arsyad, J. Gai, L. D. Ploper, A. Porta-Puglia, H. H. Ram, and J. T. Yorinori. 1997. Soybean disease loss estimates for the top 10 soybean producing countries in 1994. Plant Dis. 81:107-110.

Wrather, J. A., D. A. Sleper, W. E. Stevens, J. G. Shanon, and R. F. Wilson. 2003. Planting dates and cultivar effects on soybean yield, seed quality, and Phomopsis sp. seed infection. Plant Dis. 87:529-532.

Wroth, J. M. 1998. Possible role for the wild genotypes of Pisum spp. to enhance ascochyta blight resistance in pea. Australian. J. Expt. Agr. 38:469-479.

Wu, C., S. Sun, P. Nimmakayala, F. A. Santos, K. Meksem, R. Springman, K. Ding, D. A. Lightfoot, and H.-B. Zhang. 2004a. A BAC- and BIBAC-based physical map of the soybean genome. Genome Res (http://www.genome.org/cgi/doi/10.1101/gr.1405004).

Wu, C.-C., P. Nimmakayala, F. A. Santos, R. Springman, C. Scheuring, K. Meksem, D. A. Lightfoot, and H.-B. Zhang. 2004b. Construction and characterization of a soybean bacterial artificial chromosome library and use of multiple complementary libraries for genome physical mapping. Theor. Appl. Genet. 109:1041-1050.

Xu, D., X. Duan, B. Wang, B. Hong, T.-H. D. Ho, and R. Wu. 1996. Expression of a late embryogenesis abundant protein gene, HVAI, from barley confers tolerance to water deficit and salt stress in transgenic rice. Plant Physiol. 110:249-257.

Xu, K., R. Deb, and D. J. Mackill. 2004. A microsatellite marker and a codominant PCRbased marker for marker-assisted selection of submergence tolerance in rice. Crop Sci. $44: 248-253$.

Xu, R. Q., N. Tomooka, D. A. Vaughan, and K. Doi. 2000a. The Vigna angularis complex: genetic variation and relationships revealed by RAPD analysis and their implication for in situ conservation and domestication. Genet. Resourc. Crop Evol. 47:123-134.

Xu, R. Q., N. Tomooka, and D. A. Vaughan. 2000b. AFLP markers for characterizing the Adzuki bean complex. Crop Sci. 40:808-815.

Yahyaoui, F. E., H. Kuster, B. B. Amor, N. Hohnjec, A. Puhler, A. Becker, J. Gouzy, T. Vernie, C. Gough, A. Niebel, L. Godiard, and P. Gamas. 2004. Expression profiling in Medicago truncatula identifies more than 750 genes differentially expressed during nodulation, including many potential regulators of the symbiotic program. Plant Physiol (www.plant physiol.org/cgi/DOI/10.1104.043612).

Yaish, M. W. F., and M. P. de la Vega. 2003. Isolation of $(\mathrm{GA})_{\mathrm{n}}$ microsatellite sequences and description of a predicted MADS-box sequence isolated from common bean (Phaseolus vulgaris L.). Genet. Mol. Biol. 26:337-342.

Yamada, N. 1974. Biological nitrogen fixation-Limitless resources supporting agriculture. (In Ja.) Nettai Noken Shuho 25:20-28.

Yamaguchi, H. 1992. Wild and weedy adzuki beans in Japan. Econ. Bot. 46:384-394.

Yan, H. H., J. Mudge, D.-J. Kim, D. Larsen, R. C. Shoemaker, D. R. Cook, and N. D. Young. 2003. Estimates of conserved microsynteny among genomes of Glycine max, Medicago truncatula, and Arabidopsis thaliana. Theor. Appl. Genet. 106:1256-1265.

Yin, X., M. J. Kropff, and P. Stam. 1999. The role of ecophysiological models in QTL analysis: the example of specific leaf area in barley. Heredity 82:415-421.

Yin, X., P. C. Struik, and M. J. Kropff. 2004. Role of crop physiology in predicting geneto-phenotype relationships. Trends Plant Sci. 9:426-432.

Yin, X., P. Stam, M. J. Kropff, and A. H. C. M. Schapendonk. 2003. Crop modeling, QTL mapping, and their complementary role in plant breeding. Agron. J. 95:90-98.

Yoshimura, S., A. Yoshimura, N. Iwata, S. McCouch, M. L. Abenes, M. R. Baraoidan, T. Mew, and R. J. Nelson. 1995. Tagging and combining bacterial blight resistance genes in rice using RAPD and RFLP markers. Mol. Breed. 1:375-387. 
Young, N. D. 1999. A cautiously optimistic vision for marker-assisted breeding. Mol. Breed. 5:505-510.

Young, N. D., D. Danesh, D. Menancia-Hautea, and L. Kumar. 1993. Mapping oligogenic resistance to powdery mildew in mungbean with RFLPs. Theor. Appl. Genet. 87: 243-249.

Young, N. D., and J. D. Kelly. 1996. Characterization of the genetic resistance to Colletotrichum lindemuthianum in common bean differential cultivars. Plant Dis. 80:650-654.

Young, N. D., and J. D. Kelly. 1997. RAPD markers linked to three major anthracnose resistance genes in common bean. Crop Sci. 37:940-946.

Young, N. D., M. Melotto, R. O. Nodari, and J. D. Kelly. 1998. Marker-assisted dissection of the oligogenic anthracnose resistance in the common bean cultivar, G2333. Theor. Appl. Genet. 96:87-94.

Young, N. D., J. Mudge, and T. H. N. Ellis. 2003. Legume genomes: more than peas in a nod. Curr. Opin. Plant Biol. 6:199-204.

Young, N. D., and S. D. Tanksley. 1989. RFLP analysis of the size of chromosomal segments retained around the Tm-2 locus of tomato during backcrossing. Theor. Appl. Genet. 77:353-359.

Yu, K., S. J. Park, and V. Poysa. 1999. Abundance and variation of microsatellite DNA sequences in bean (Paseolus and Vigna). Genome 42:27-34.

Yu, K., S. J. Park, and V. Poysa. 2000. Marker-assisted selection of common beans for resistance to common bacterial blight: efficacy and economics. Plant Breed. 19:411-415.

Yu, Y. G., G. R. Buss, and M. A. Saghai-Maroof. 1996. Isolation of a super family of candidate disease-resistance genes in soybean based on a conserved nucleotide-binding site. Proc. Natl. Acad. Sci. (USA) 93:11751-11756.

Yu, Z. H., R. E. Stall, and C. E. Vallejos. 1998. Detection of genes for resistance to common bacterial blight of beans. Crop Sci. 38:1290-1296.

Yunus, A. G., and M. T. Jackson. 1991. The gene pools of the grasspea (Lathyrus sativus L.). Plant Breed. 106:319-328.

Zeven, A. C., and J. M. J. de Wet. 1982. Dictionary of cultivated plants and their regions of diversity. Centre for Agricultural Publication and Documentation, Wageningen.

Zeven, A. C., J. Waninge, T. van Hintum, and S. P. Singh. 1999. Phenotypic variation in a core collection of common bean (Phaseolus vulgaris L.) in the Netherlands. Euphytica 109:93-106.

Zhang, H. X., and E. Blumwald. 2001. Transgenic salt tolerant tomato plants accumulate salt in the foliage but not in the fruits. Nat. Biotech. 19:765-768.

Zhang, H. X., J. N. Hodson, J. P. Williams, and E. Blumwald. 2001. Engineering salttolerant Brassica plants: characterization of yield and seed oil quality in transgenic plants with increased vacuolar sodium accumulation. Proc. Natl. Acad. Sci. (USA) 98:12832-12836.

Zhang, W.-K., Y.-J. Wang, G.-Z. Luo, J. Z. Zhang, C.-Y. He, X.-L. Wu, J.-Y. Gai, and S.-Y. Chen. 2004. QTL mapping of ten agronomic traits on the soybean (Glycine max Merr.) genetic map and their association with EST markers. Theor. Appl. Genet. 108: 1131-1139.

Zhu, H., S. B. Cannon, N. D. Young, and D. R. Cook. 2002. Phylogeny and genomic organization of the TIR and non-TIR NBS-LRR resistance gene family in Medicago truncatula. Mol. Plant Microbe Interact. 15:529-539.

Zhu, H., D.-J. Kim, J.-M. Baek, H.-K. Choi, L. C. Ellis, H. Kuester, W. R. McCombie, H.-M. Peng, and D. R. Cook. 2003b. Syntenic relationships between Medicago truncatula and 
Arabidopsis reveal extensive divergence of genome organization. Plant Physiol. 131:1018-1026.

Zhu, T., J. M. Schupp, A. Oliphant, and P. Keim. 1994. Hypomethylated sequences: characterization of the duplicate soybean genome. Mol. Gen. Genet. 244:638-645.

Zhu, T., and X. Wang. 2000. Large-scale profiling of the Arabidopsis transcriptome. Plant Physiol. 124:1472-1476.

Zhu, Y. L., Q. J. Song, D. L. Hyten, C. P. van Tassell, L. K. Matukumalli, D. R. Grimm, S. M. Hyatt, E. W. Fickus, N. D. Young, and P. B. Cregan. 2003a. Single-nucleotide polymorphisms in soybean. Genetics 163:1123-1134.

Zhuang, B. C., Y. J. Sun, Q. H. Lu, Y. M. Wang, and B. Xu. 1996. A study on resistance to soybean mosaic virus and Aphis glycinece of perennial wild soybean. Soybean Genet. Newslett. 23:66-69. 